Historic, Archive Document

Do not assume content reflects current scientific knowledge, policies, or practices. 



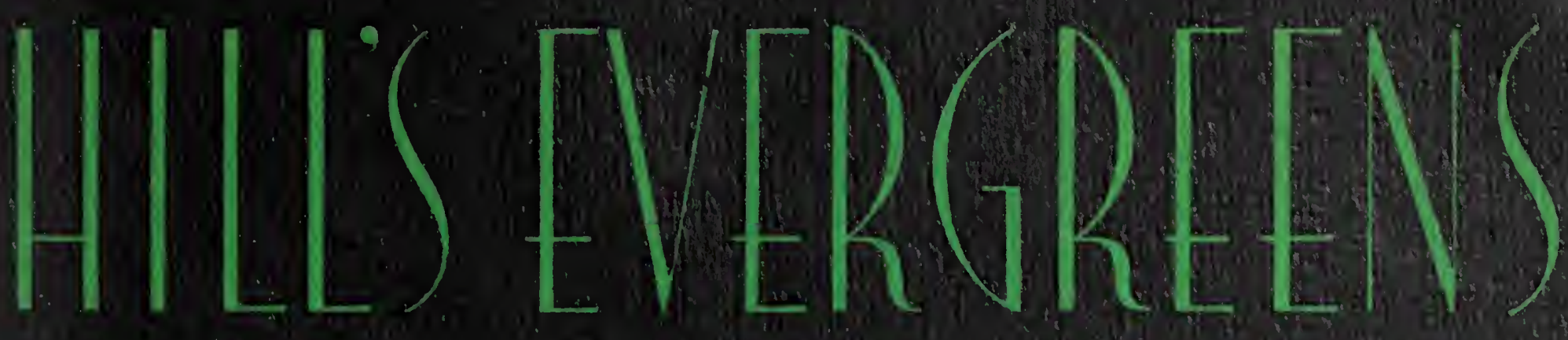

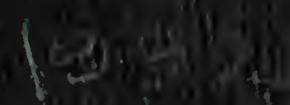

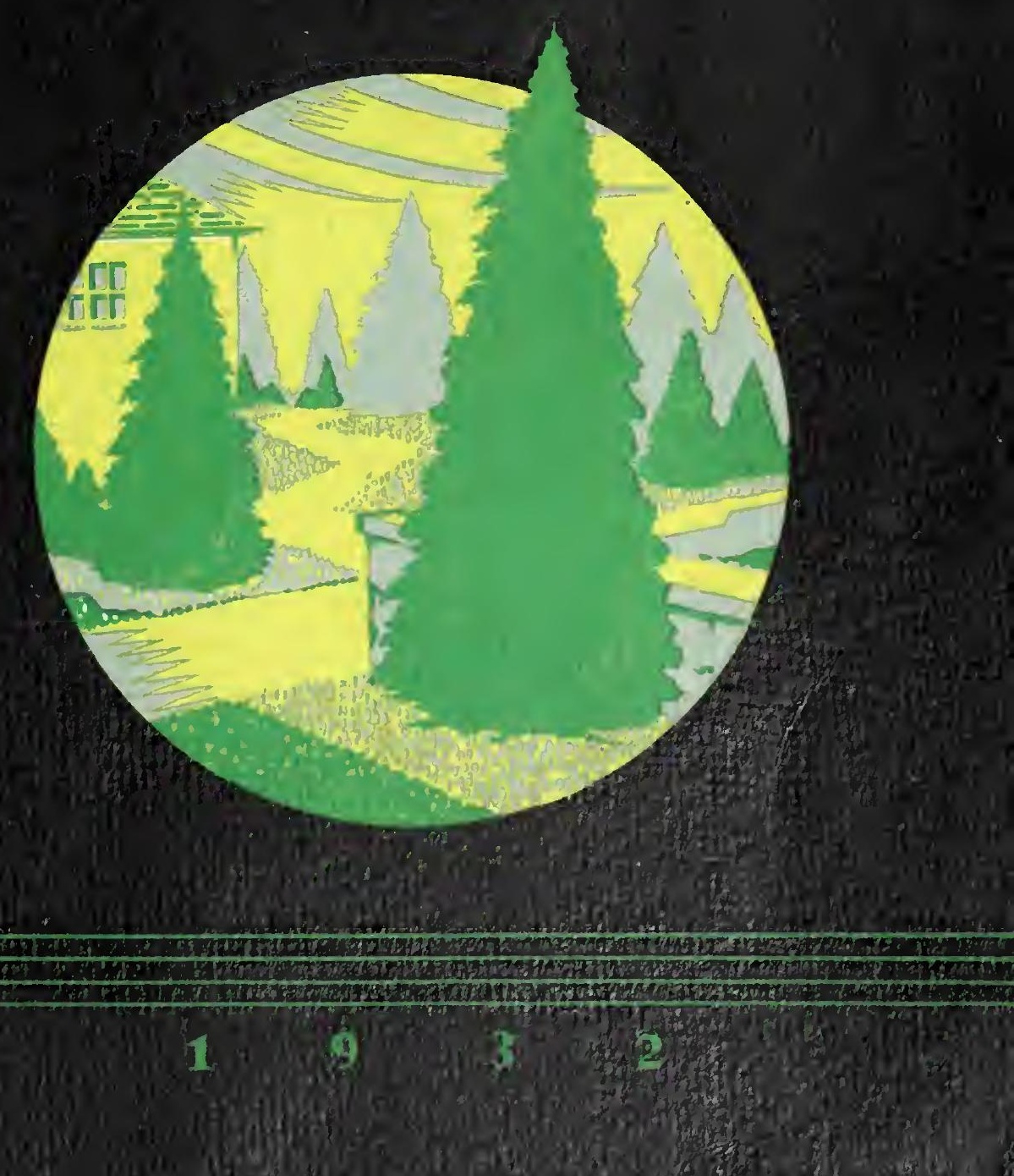



L I B R A R X 12 x: $C \backsim \nabla \pi 0$ * MAY $161932 \star$

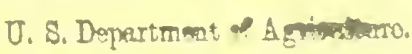

\section{HILL'S EVERGREENS}

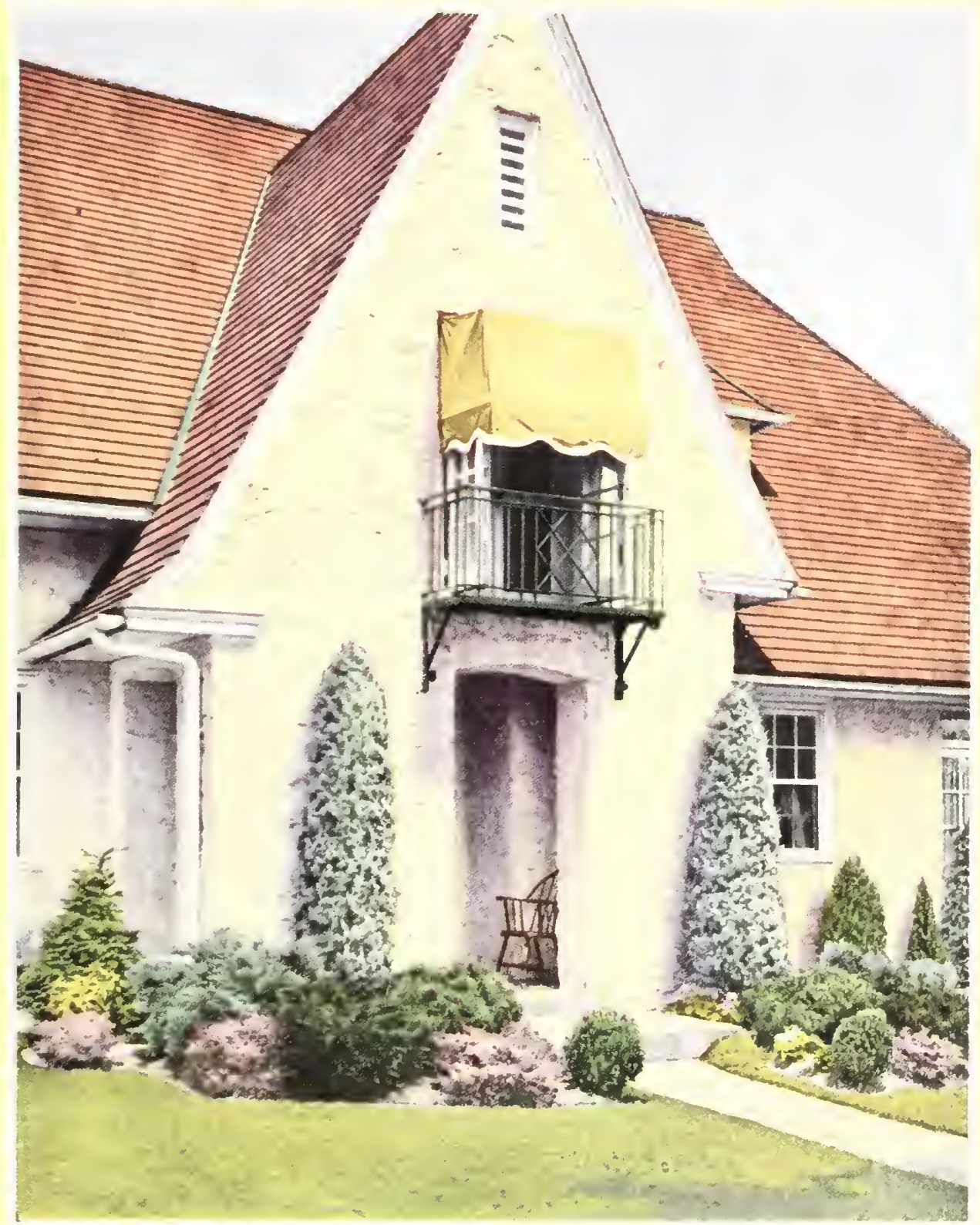

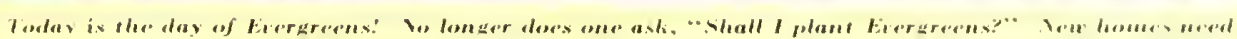

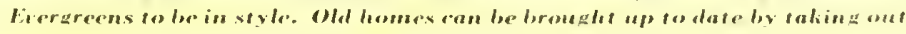

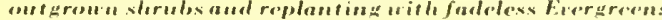

\section{HILL NURSERY CO.}

Evergreen Specialists - Largest Growers in America DUNDEE · ILLINOIS 


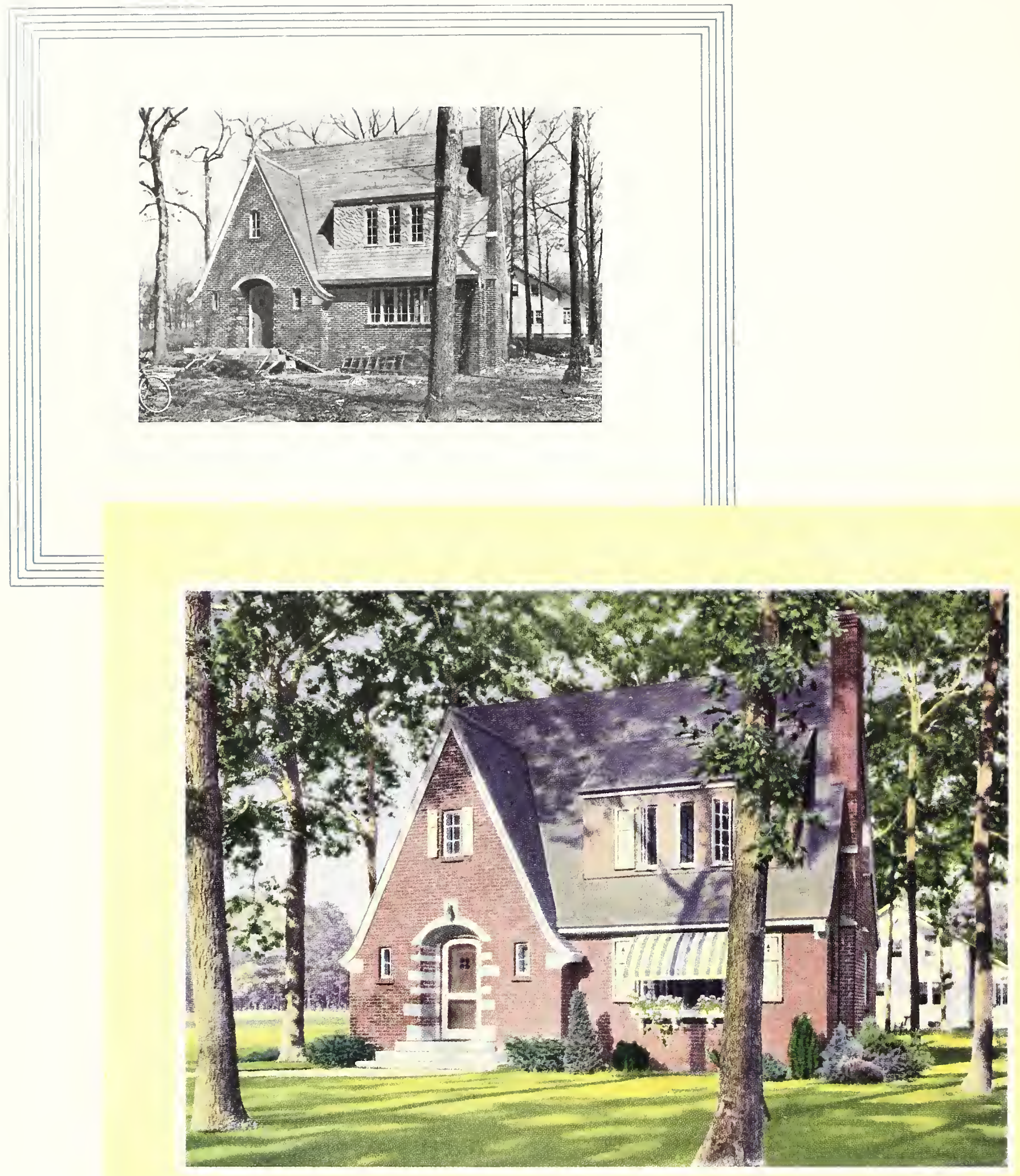

Fine Exergreens around the hause are as essential as fine furniture inside the house. Few people see the inside of your home. Fou are judged by outside appearances. Hill Erergreens make you proud of vour lome, while their attrartire beaty will appeal to all whopass by 


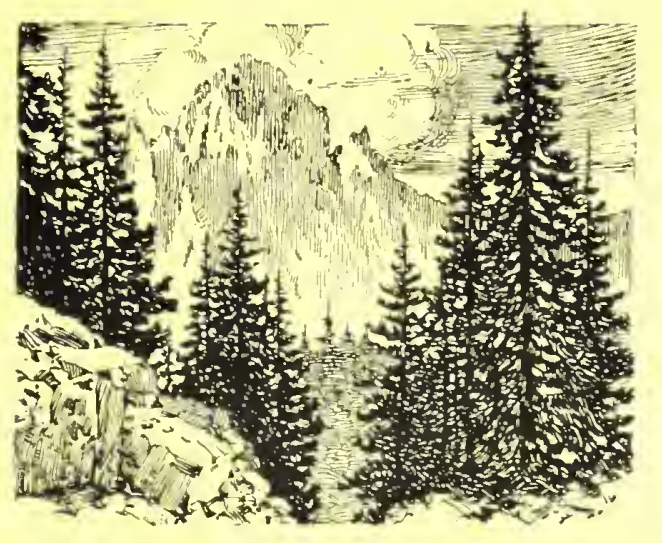

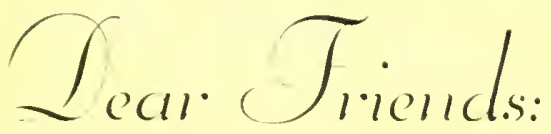

To each suceceding gencration since 1855, Hill Evergreens have given the brot that could be had in Evergreens. Today there are new uses for Evergreens, new colors, new shapes, new styles. Erergreens have become a simbol of the up-to-date home grounds.

You seek beauty and refinement in your home surroundings. Fine Evergreens satisfy that same desire for charm and regance in your grommds that the finest of furmishings give to the interior of the homse.

Evergreens help to give charactro to a home because we naturally associate them with permanence. Thery stay, and their presence suggests the kind of people who stay. Although not all grounds are large enough for

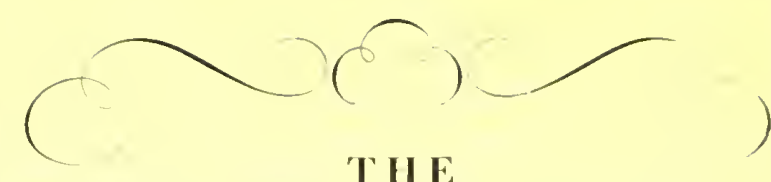

FIDELESS EVERGREENS

Beauty and grace in its form rembine. A monareh, bern of a nothle line. Long ma it he ere its race dectine? Frost stall not wither a leaf of thine. Fearlesis and farleless Pine!

$$
\text { - II F. Tínен }
$$

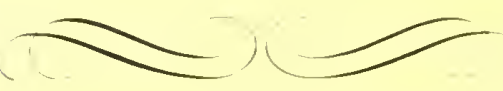

extensire plantings of Evergreens. this does not mean that the prerson owning a small city or suburbiu bot camnot enjoy their cheer also. If it is not for more than a pair of trees at the entrance, there is always a place for Evergreens. The love of trees is a herilage of all men.

\footnotetext{
"I tree is one of nature's wordh. a word of prace to man.

I worl that tells of central strength from whene all things leegan.

I word to preach tranquillity Io all our restlens clan.
}

Wh. laare mu-t he the shatelese way. and bleak the path must bee

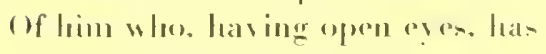

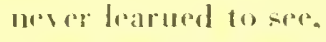

Ind so has never learned lo love the beatuly of al tree."-II. Kel,os.

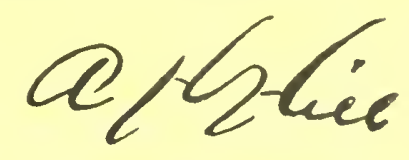

President. 

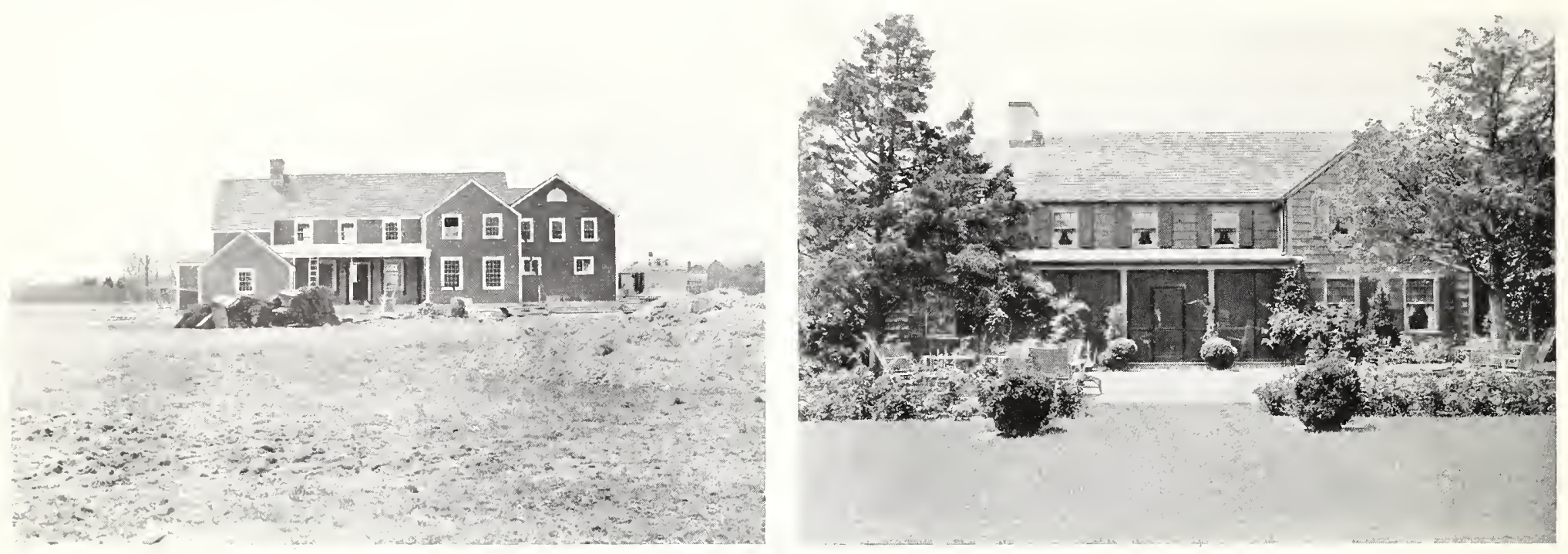

\section{A New Vogue Is Sweeping the Country}

$\mathrm{E}$ ERITH HERE we look we see fresh evidence of the great desire for beautiful home surroundings that is sweeping the country. The editors of our great magazines and newspapers, whose fingers are ever on the public pulse, are fully conscious of this trend and are devoting ever increasing space to the subject of beautifying the home grounds.

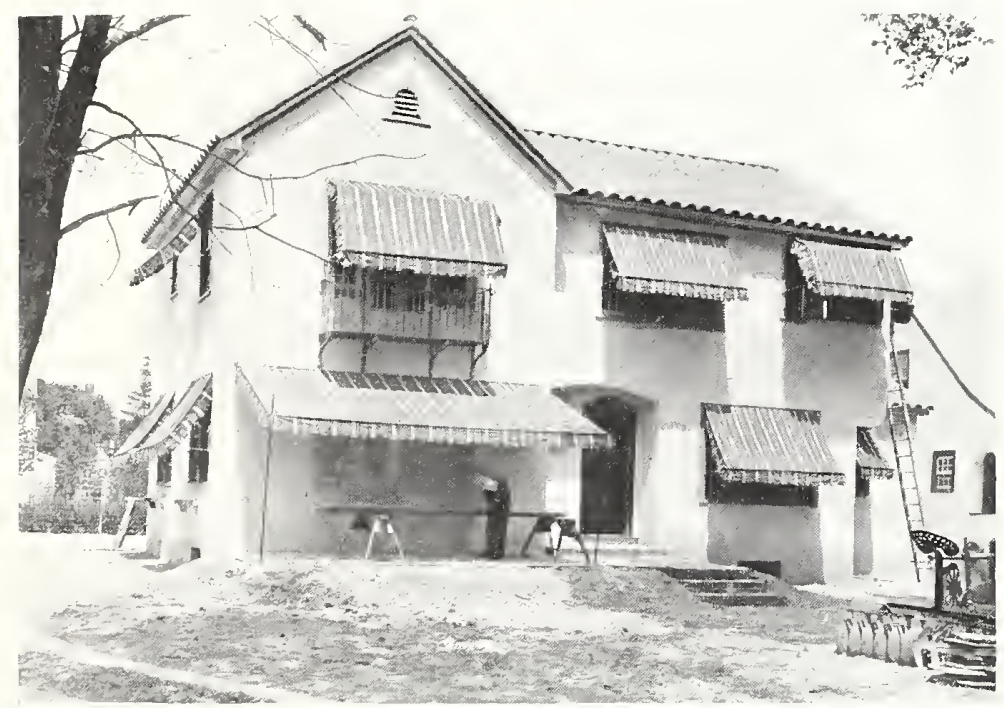

As a result, the eyes of the American people are being directed, as never before, to their home surroundings. Garden Clubs are springing up every where, and all over America one finds a new interest in the fascinating pastime of beautifying the home. America will become the garden spot of the world when every citizen comes fully to realize that-" "It's Not a Home Until It's Planted.'

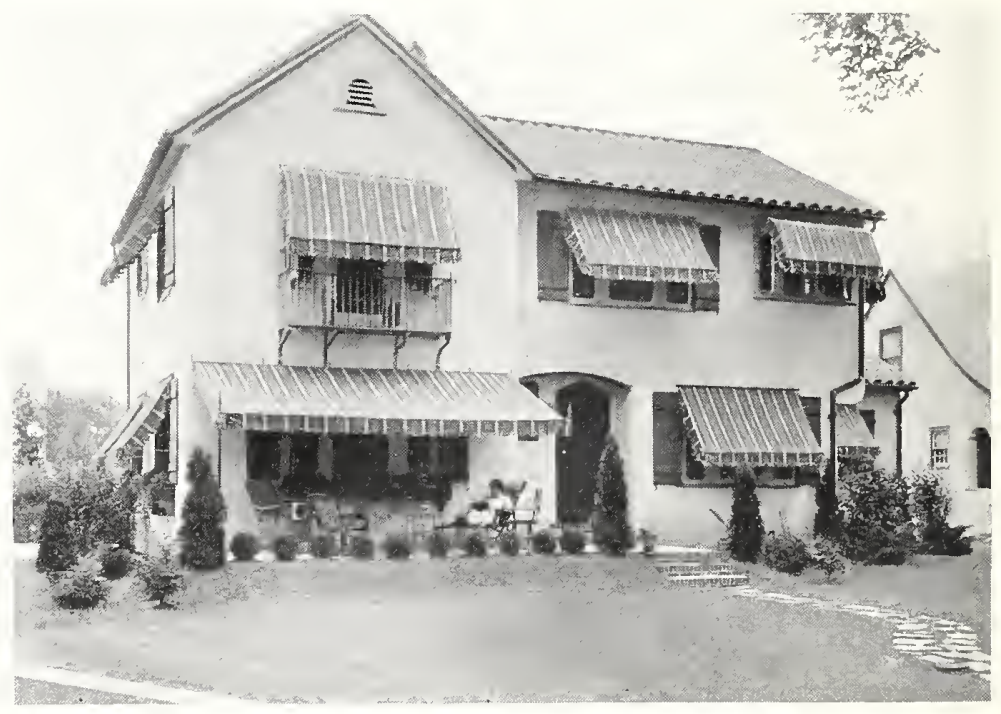

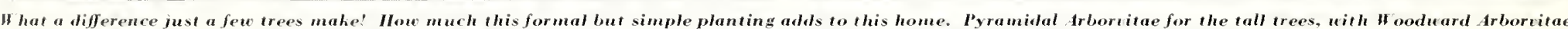
for the low ball-shaped trees. With a small group of llemlock at the edge of the terrace. completes this attractive grouping. The open onthor living room is now an important part of the llew order in planning homes
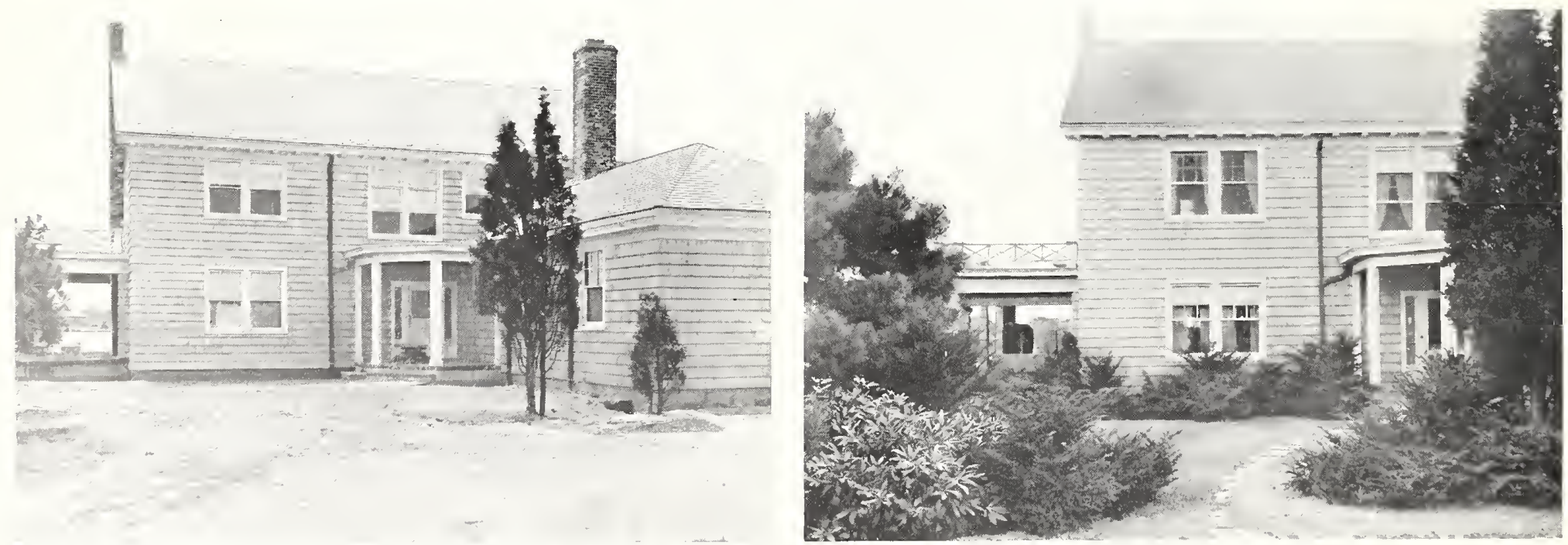


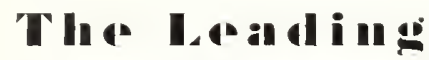
Fin ill i l i a s o o f Evergations
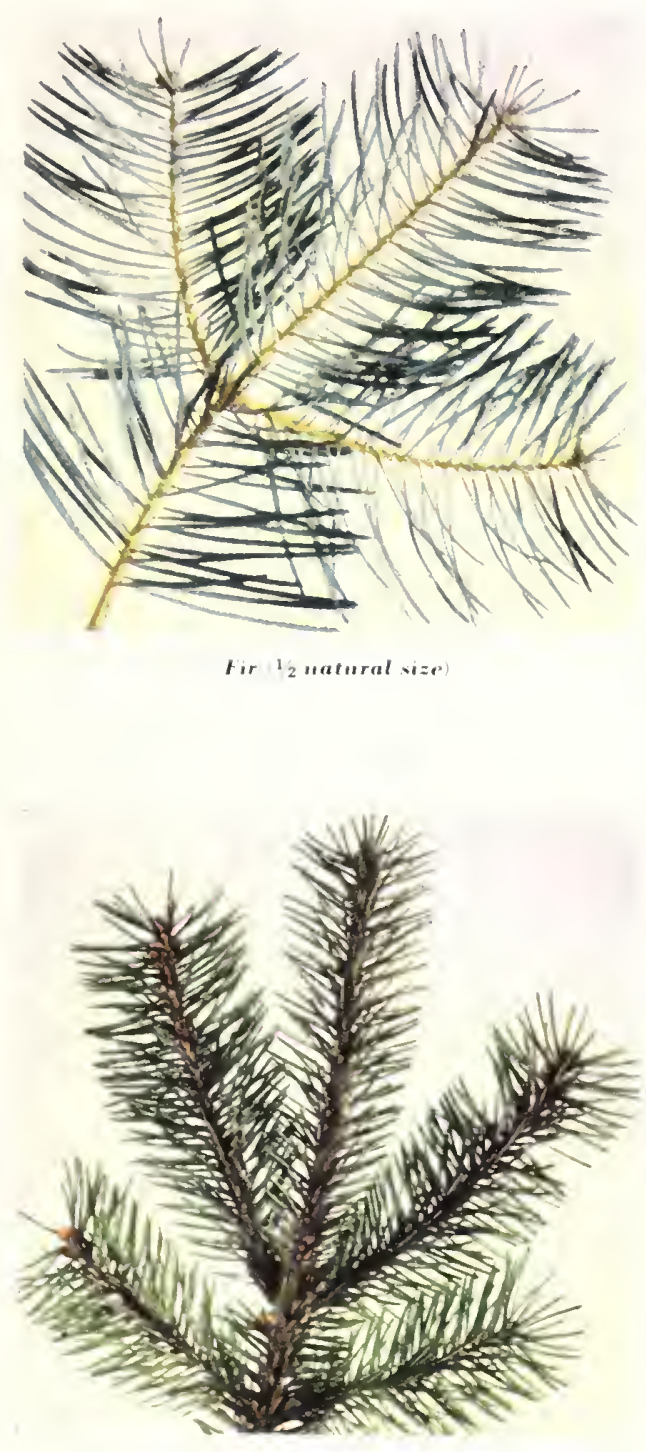

All the varieties of Exerereens grown at the Hill Nursery helong to ome of the seren distinet families of trese represented by these colored photographe. In Juniper-, for instance, thirty or more varieties are grown but all of them bear rememblance to the photograph of Juniper foliage picturet here. Differenees oceur in the shape of the trees. color and other characteristics. By carefully studying this chart anyone may easily learn to identify Evergreens ac-
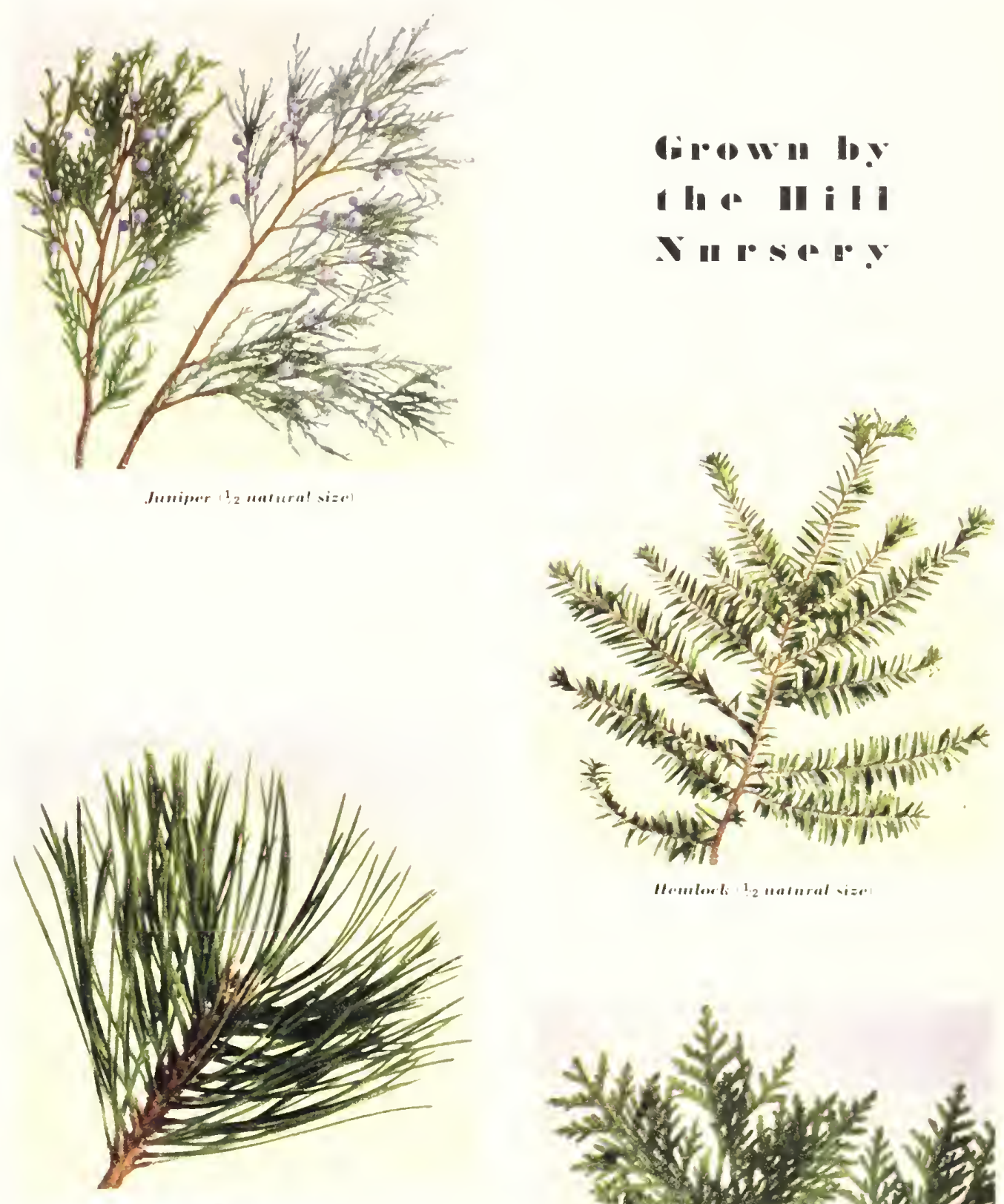

(iinow in lo.

I It a II i I I

N II I s a a
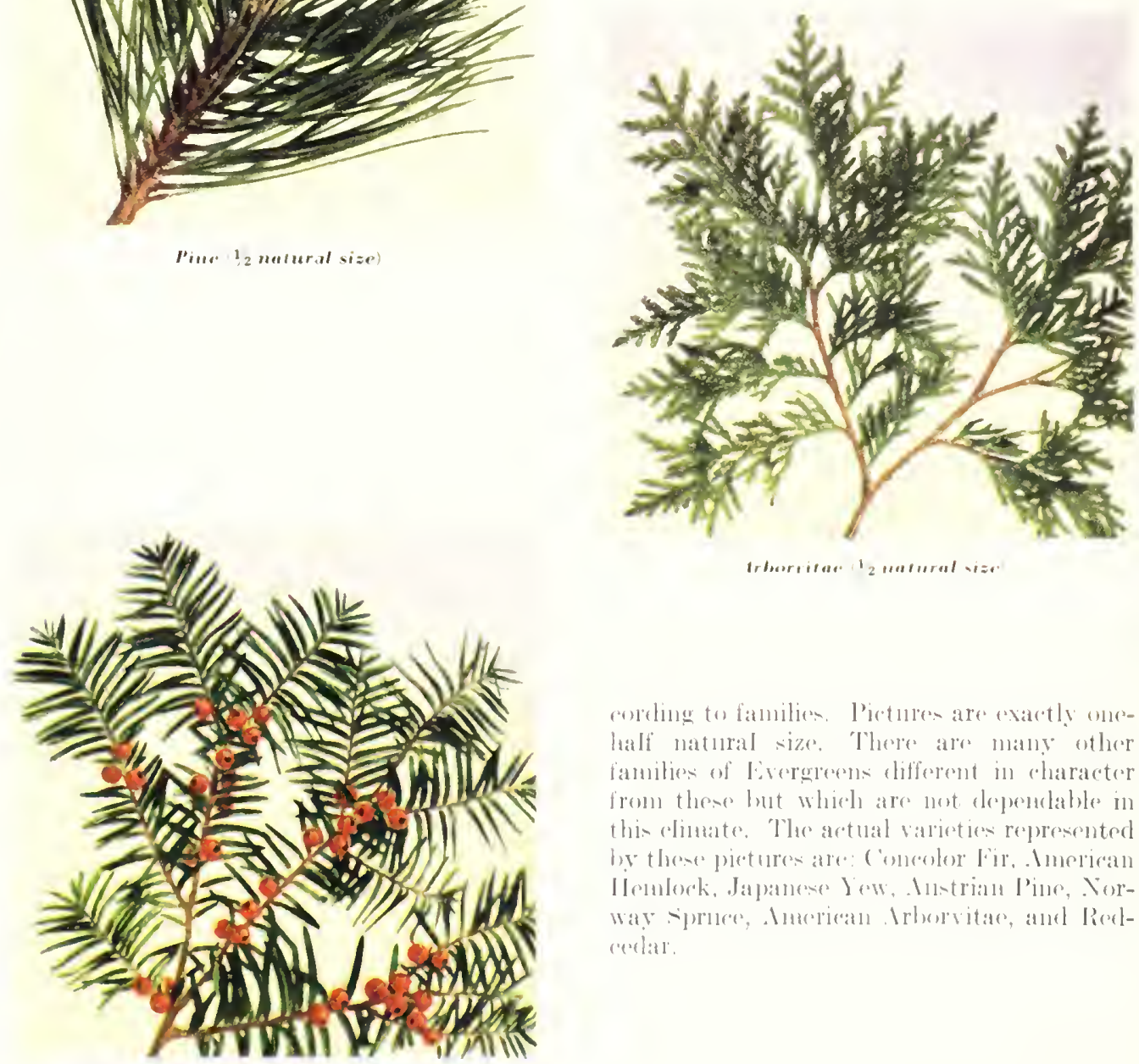

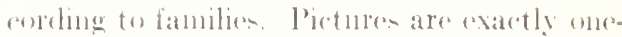
half natural size. There are many other lamilies of livergerens chifferent in character

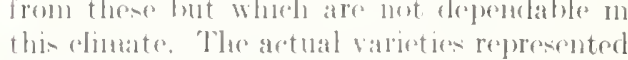
by these pieturex are: ('oneolor Fir. . Ameriman Ilenlock, Japanese low, Anstrian Jine, Nor-

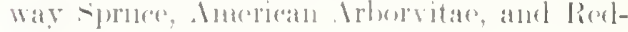
(12ilat. 

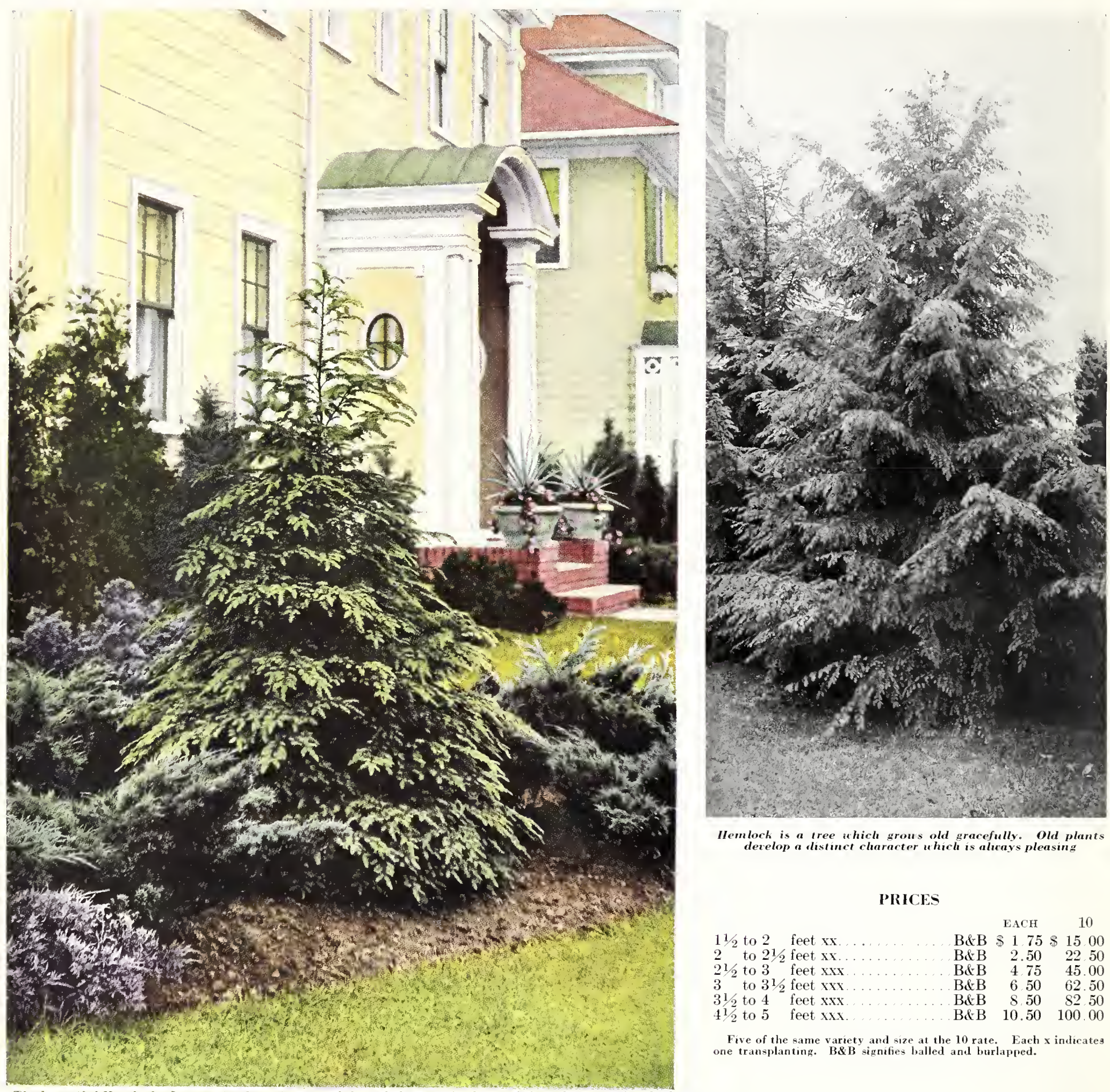

Hemloch is a tree which grous old gracefully. Old plants develop a ristinct character uhich is aluays pleasing

PRICES

$11 / 2$ to 2 feet $\mathrm{xx}$

2 to $21 \%$ feet $\mathrm{xx}$

$21 / 2$ to 3 feet $x x x$

3 to $31 / 2$ feet $\mathrm{xxx}$

$31 / 2$ to 4 feet $\mathrm{xxx}$

$41 \frac{1}{2}$ to 5 feet $\mathrm{xxx}$.
EACH $\quad 10$

$\mathrm{B} \& \mathrm{~B} \$ 1.75 \$ 1500$

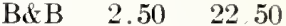

$\begin{array}{llll}\mathrm{B} \& \mathrm{~B} & 4 & 75 & 45.00\end{array}$

$\begin{array}{llll}B \& B & 6.50 & 62.50\end{array}$

$\begin{array}{llll}\text { B\&B } & 8.50 & 82.50\end{array}$

$\begin{array}{lll}\mathrm{B} \& \mathrm{~B} & 10.50 & 100.00\end{array}$

Five of the same variety and size at the 10 rate. Each $x$ indicates one transplanting. B\&B simnifies balled and burlapped.

\section{Canada Ilemlork}

\section{(Tsuga Canadensis)}

O llemlock Tree! 0 Hemlock Tree: Ilow faithful are thy branches. But in the winter's frost and rime.

o llemlock Trce! O Ilemlock Tree! How faithful are thy branches.

Longfellow.

$\mathrm{M}$

OST graceful of all Evergreens" is the titlc often bestowed on the Hemlock. Certain it is that few Evergrcens can claim the long branches droop gracefully to the ground, and the branchlets bend willingly to the breeze.

The common shape of the tree is conical, tapering evenly from a broad base to a long straight thrifty shoot. Most trees have a single main stem, but low wide-spreading trees may have several stems.
In cultivation, when planted by itself in the open, it will develop a height of 25 feet or more with a spread of branches 10 or 12 feet wide. It is most often used in connection with other trees, when the growth is retardcd a great deal.

When growing in its native stands, throughout northern Wisconsin and Michigan, it never grows in solid stands by itself. It often secks the protection and the company of other larger trees, preferring a cool, moist partially shaded spot, where it develops rich, dark green luxuriant foliage.

It is not wise to plant the Hemlock in open dry windswept places. It likes the north side of buildings, a partially shaded hillside or a partly protected spot.

The needles are soft and delicate, not more than $1 / 4$ to $1 / 2$ inch long. The color is dark green on top, glaucous or whitish beneath.

Because of its flexible branches, it can be severely trimmed, which accounts for its being used in foundation groups and elsewhere, in small 

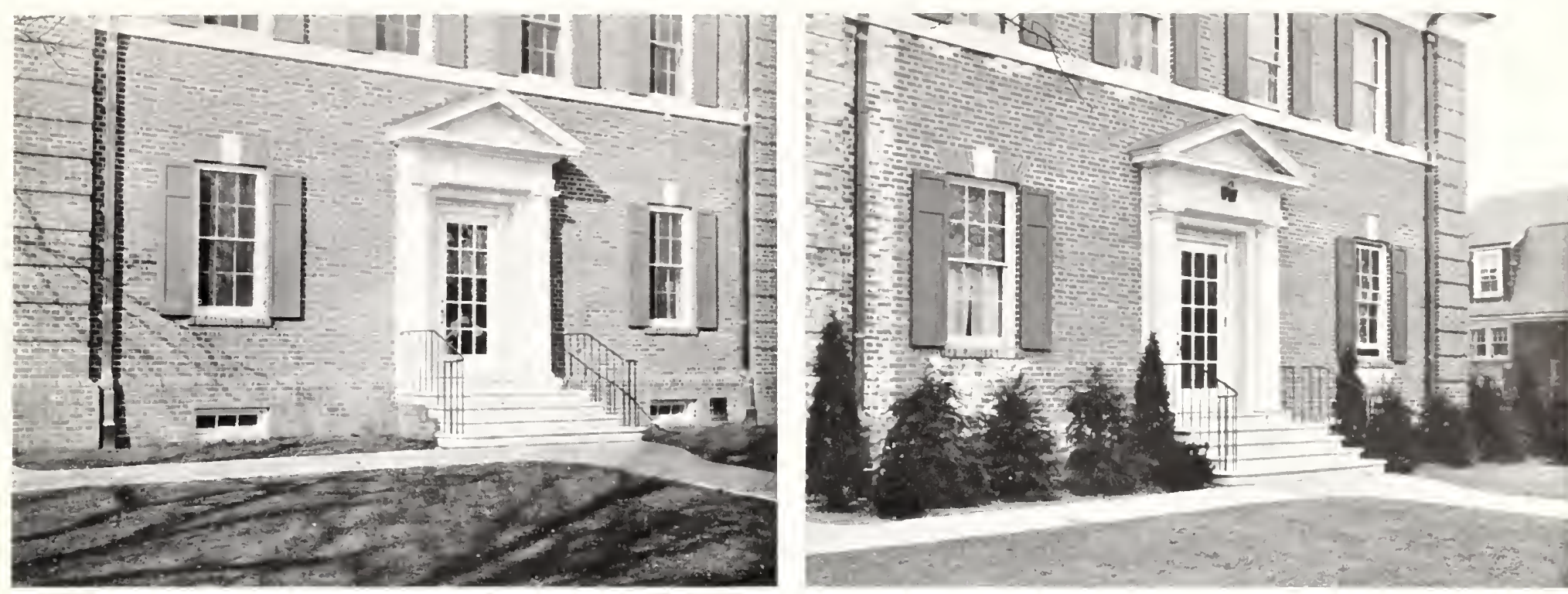

Pistures are the universal languaga. Thes speat londer than words.

pares. When trimmed it
close, compact and shapely.

As a sereen or hedge, Hemlork is areatly admired a. it bears the shears well and grows thriftily in hedges

There a great rariation in the source of seeds. Hemlock- grow abundantly in Tennessee and other southern states but only thos trees produced from Northern IIiseonsin seed will Ender favorable conditions it grows rapilly. Sumn southern exposures should be aromed on aceount of extremely dry locations, exposed to sorrehing winds.

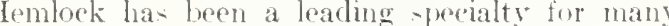

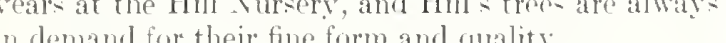
MIIMIMVIr.12 Bue little lour to lic musen So, curtaind loy a wingine Pine. Till, lowt in dreame my

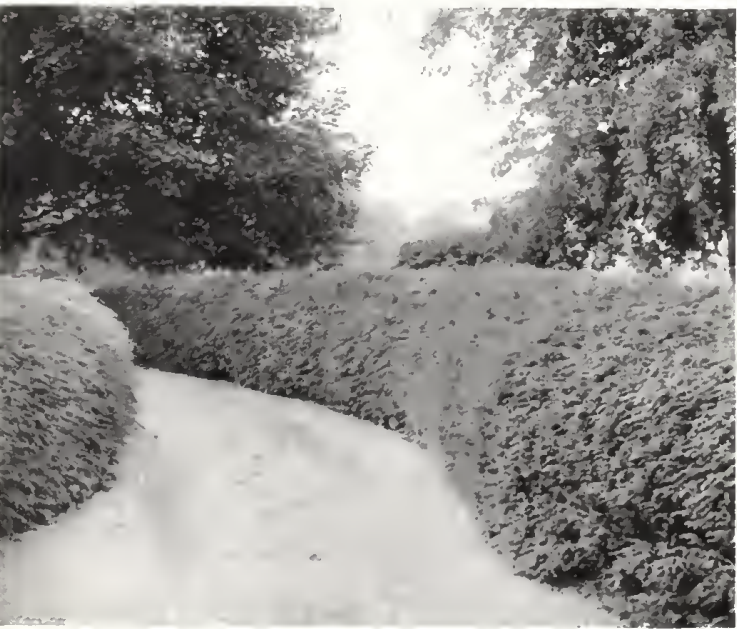

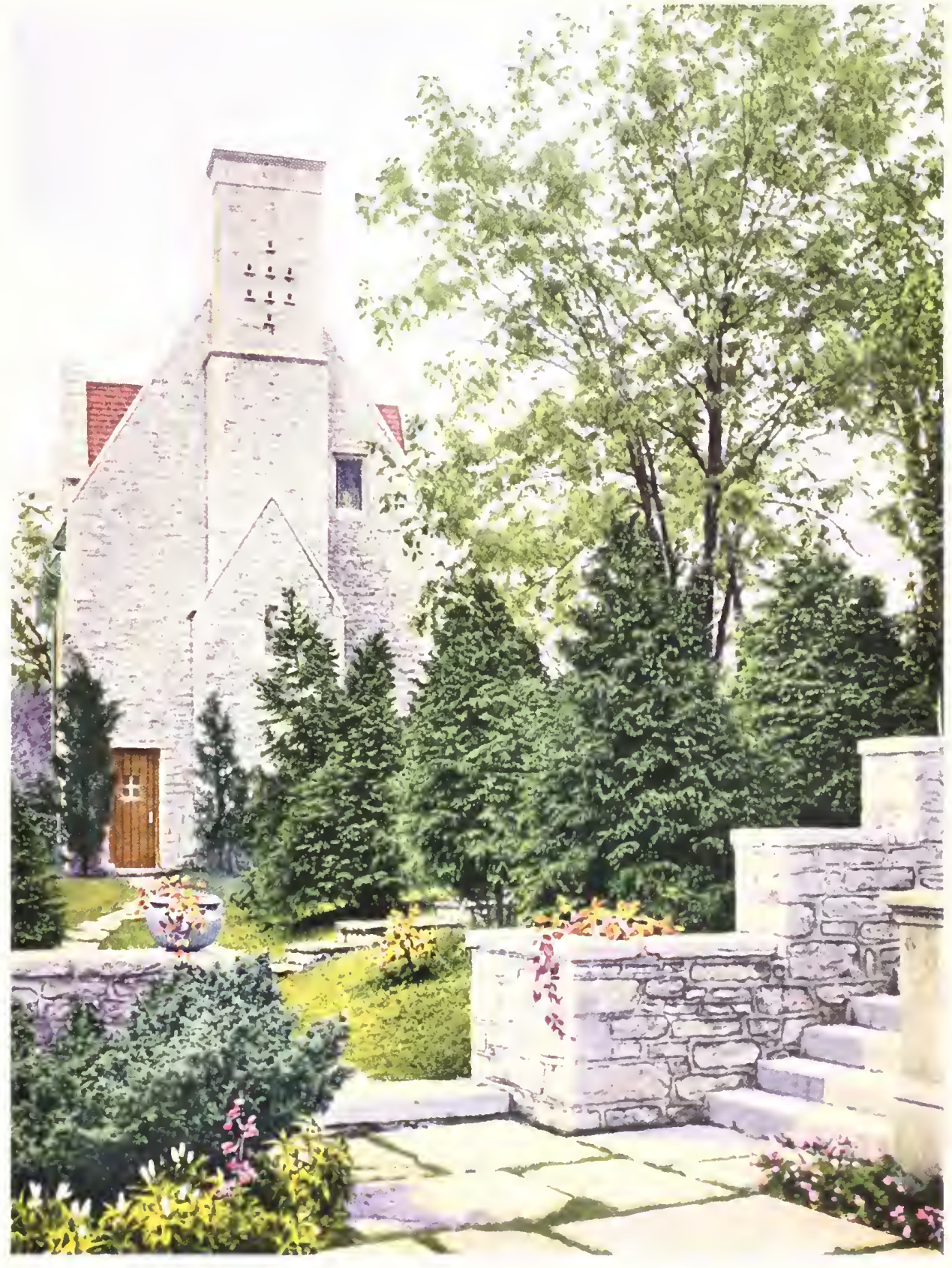




\section{Meyer Iuniper}

(Juniperus squamata meveri)

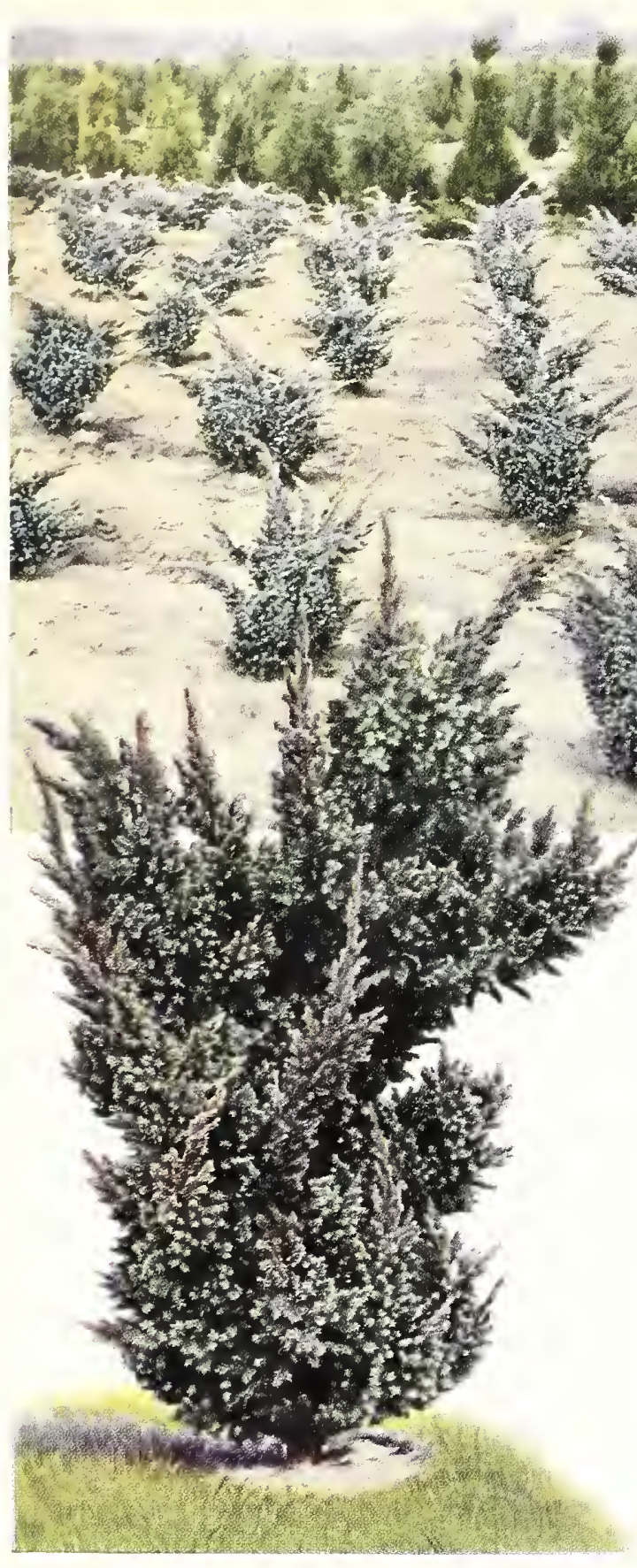

An idea of the unusual character of the Meyer Juniper can the stock as it looks in the nursery

In the chart below we have indicated a part of the varieties shown in this picture. Key for the planting shown is given at right below.

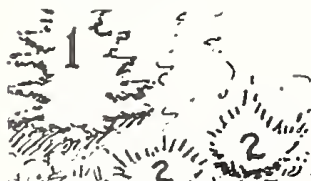

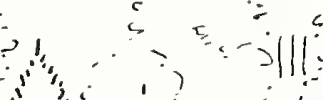
(1)

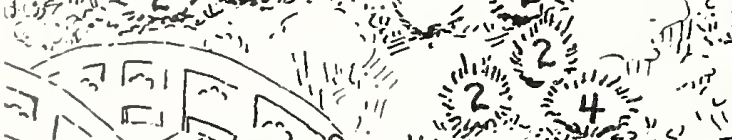

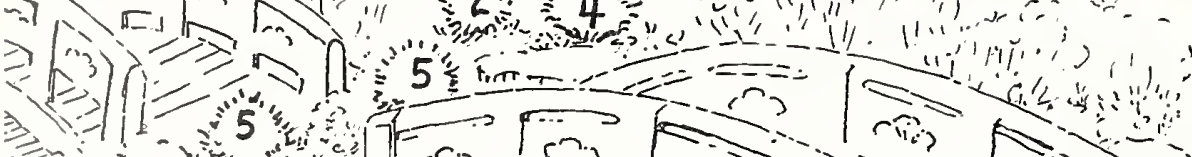

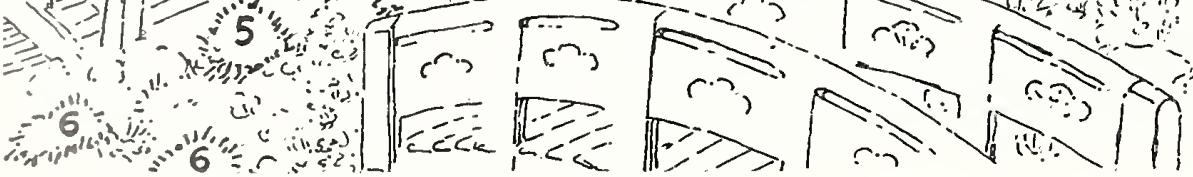

\section{A NEW NOVELTY OF UNUSUAL MERTT}

T T has a most unusual color and habit. The leaves are plump, pointed and prickly, and of bright, shining blue color. The

foliage appears of different colors when viewed from various angles. There are distinct tones of green, white and pinkish-red, making it the most striking in color of any Evergreen. It grows in an irregular form, as shown in picture.

The late Frank N. Meyer, plant explorer of the U. S. Department of Agriculture, found this tree in China. The original trees were distributed by the United States Government. It has also been called "Fish-back Juniper."

It makes an ideal planting for the rockery or around a pool It never fails to attract attention and will prove a source of great interest in your Evergreen plantings.

For rockeries, around pools, or in groups with other trees it is always conspicuous because of its unusual color and shape.

Meyer Juniper is a choice and rare tree that is appreciated by planters who want the unusual. It will win the admiration of any Evergreen enthusiast.

12 to 15 inch $\mathrm{xx}$

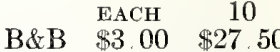

15 to 18 inch $x x$

$\mathrm{B} \& \mathrm{~B} \quad 3.50 \quad 32.50$

Five of the same variety and size at the 10 rate. Each $\mathrm{x}$ indicates one transplanting. B\&B signifies balled and burlapped.

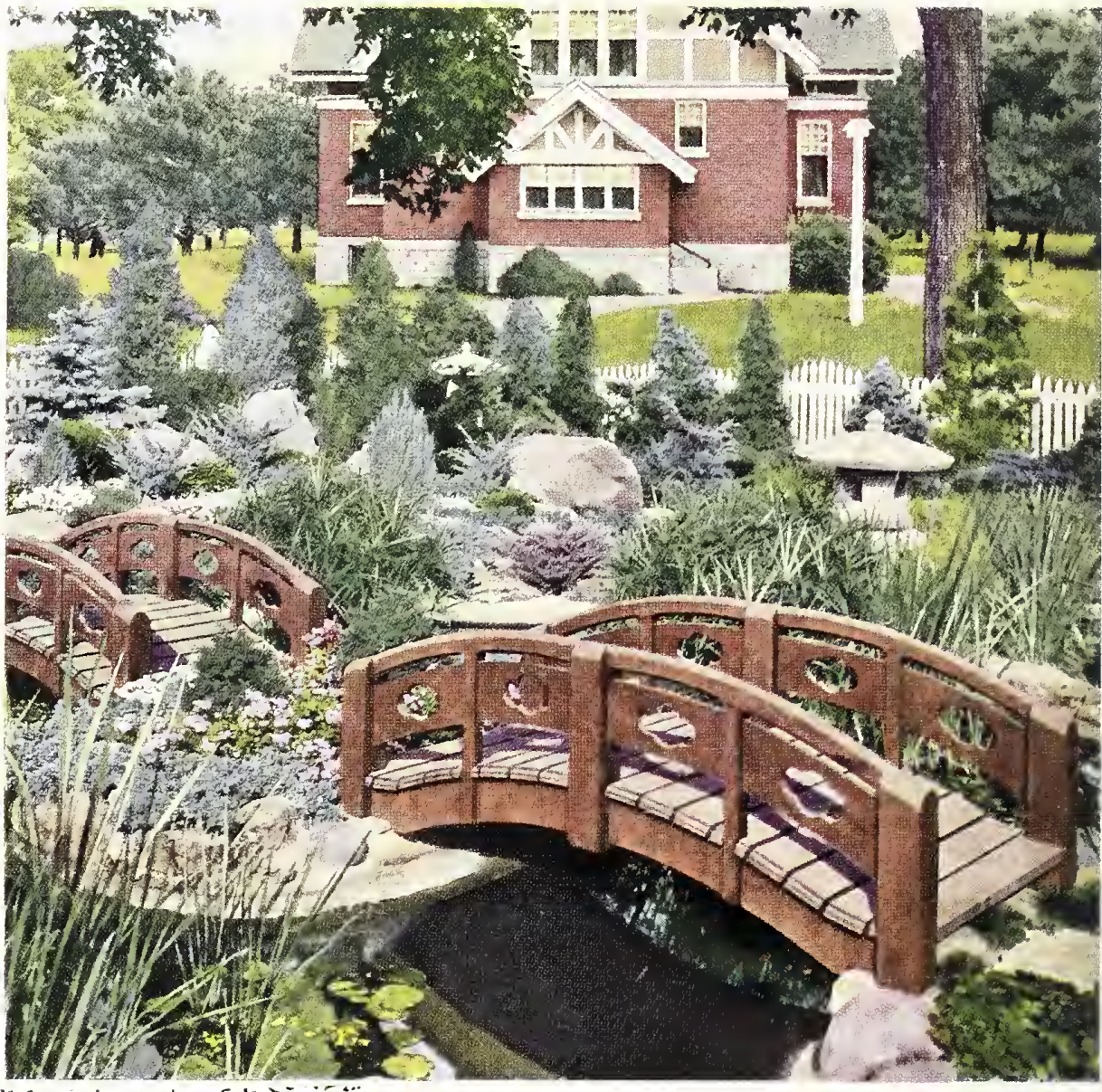

COME AND SEE THE BEAUTIFUL GARDEN

The garden pictured above is located on our nursery grounds. It contains a collection of many choice Evergreens. Visitors at the nursery are always invited to go through the grounds.

Key for planting shoun in colored picture above (I) Colorado Andorra Juniper; (5) Itemlock: (6) Japanese Juniper. 


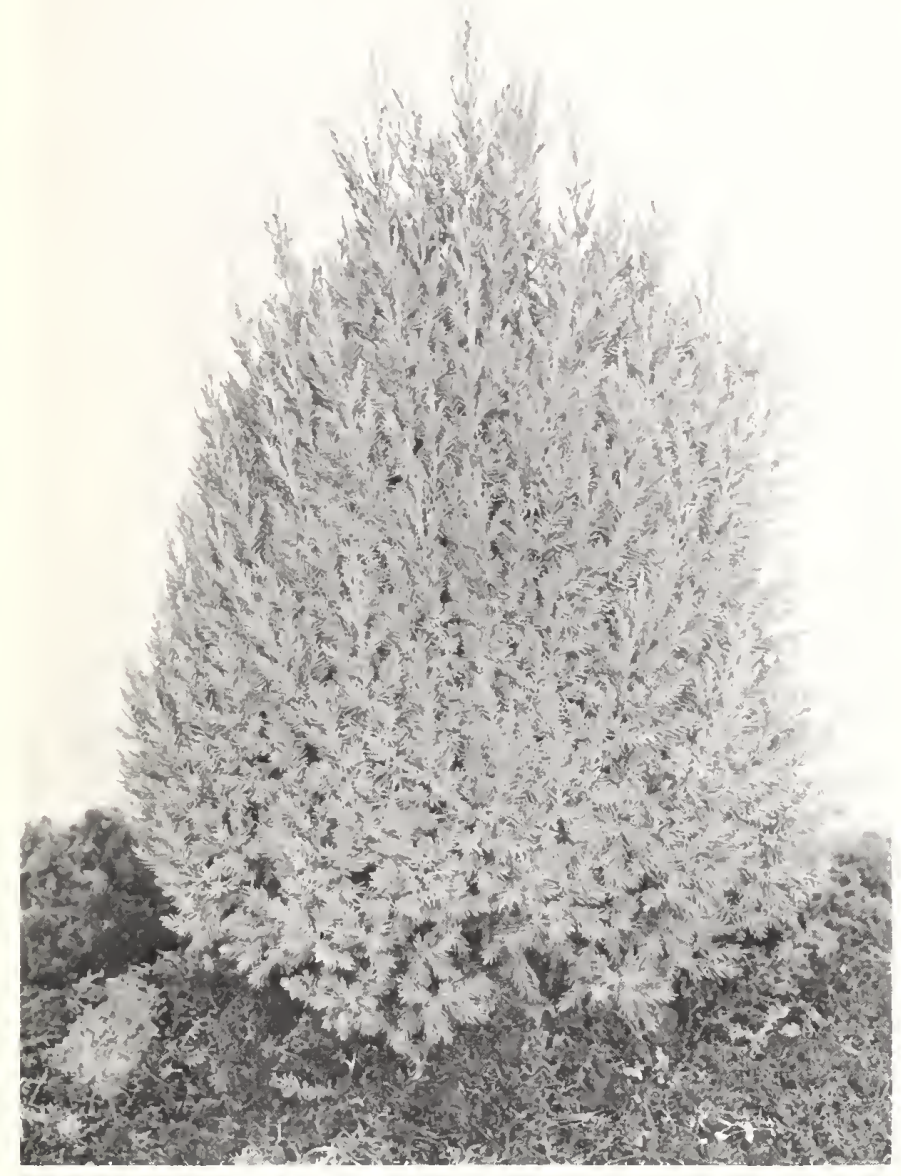

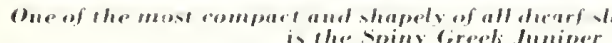

\section{Word Mboul dhe IIill Nuresery}

Sinee 1.55, the name "HILL" has been synonymous with high quality in Evergreens. Here in Dundee under ideal conditions: of soil and climate are over 600 acres of land devoted exclusively to the growing of high-class evergreen tres. No matter where you live, HILL EVTRCRELAs' can be shipped to you safely

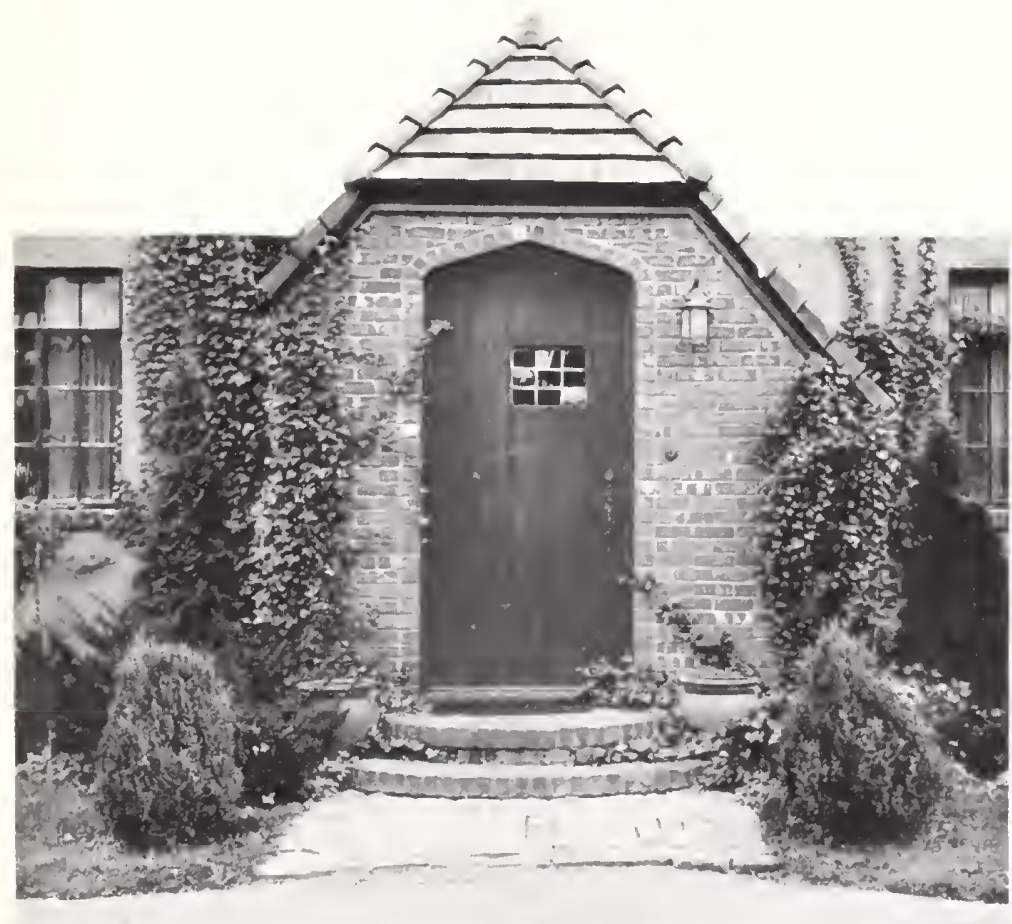

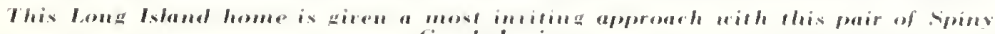

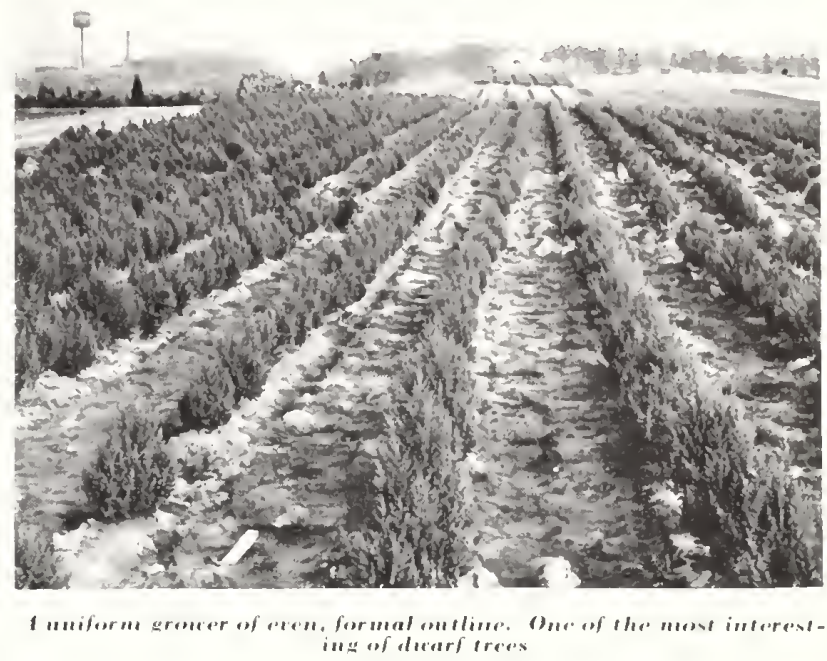

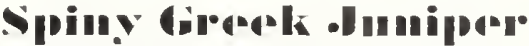

Jumiperus exerlst strichle

$\mathrm{T}$

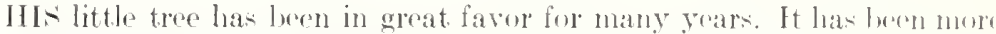
extensively used in the rastorn and soutlerm states lont is mom loremmine popular in the midlle west.

It requires a sumny dry situation for lest droveloment amel under those eondi-

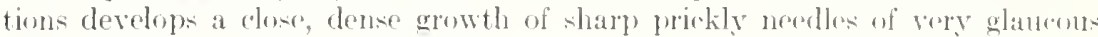
blue color.

The mother tres is a native of Greece and Asia. This horticultural form Wis first produced many years ago in the liollenson Nursey at Tootme, England

It growth is rather broarl, tapering to a pointed torminal top. In this locality trees seldom leach more than four or fire feet high with a spread of 21 or 3 feet

It grows slowly and is, therefore, of great value in foundation planting- and rock garlens.

Because of its elose arowing, "ren loranching habit, it tills a noed for a forma tree of dwart size. Eren though it grows slowly it is capable of heing trimmed ant maintained as a very small tree for many years

12 to 15 inch xx

15 to 18 inch $\mathrm{xx}$.

$11 / 2$ to 2 feot $\mathrm{xxy}$

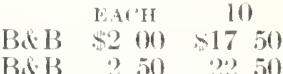

$B S B \quad 50 \quad 22.50$ ignifies balled and burlatinger

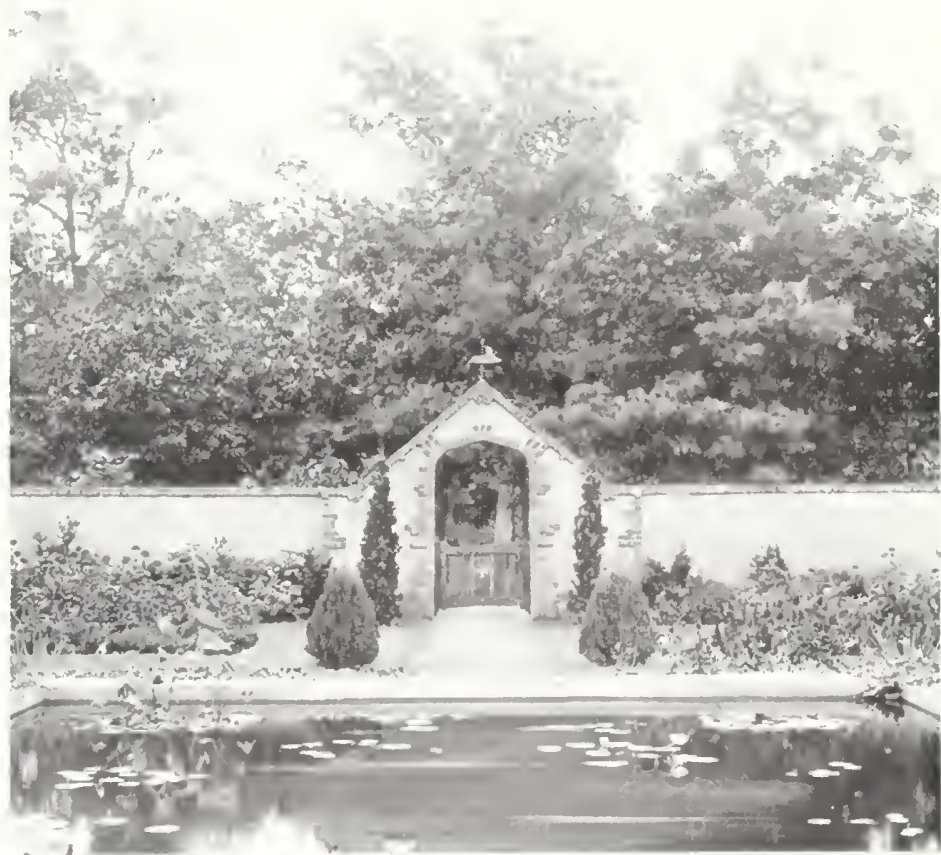

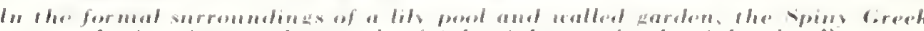




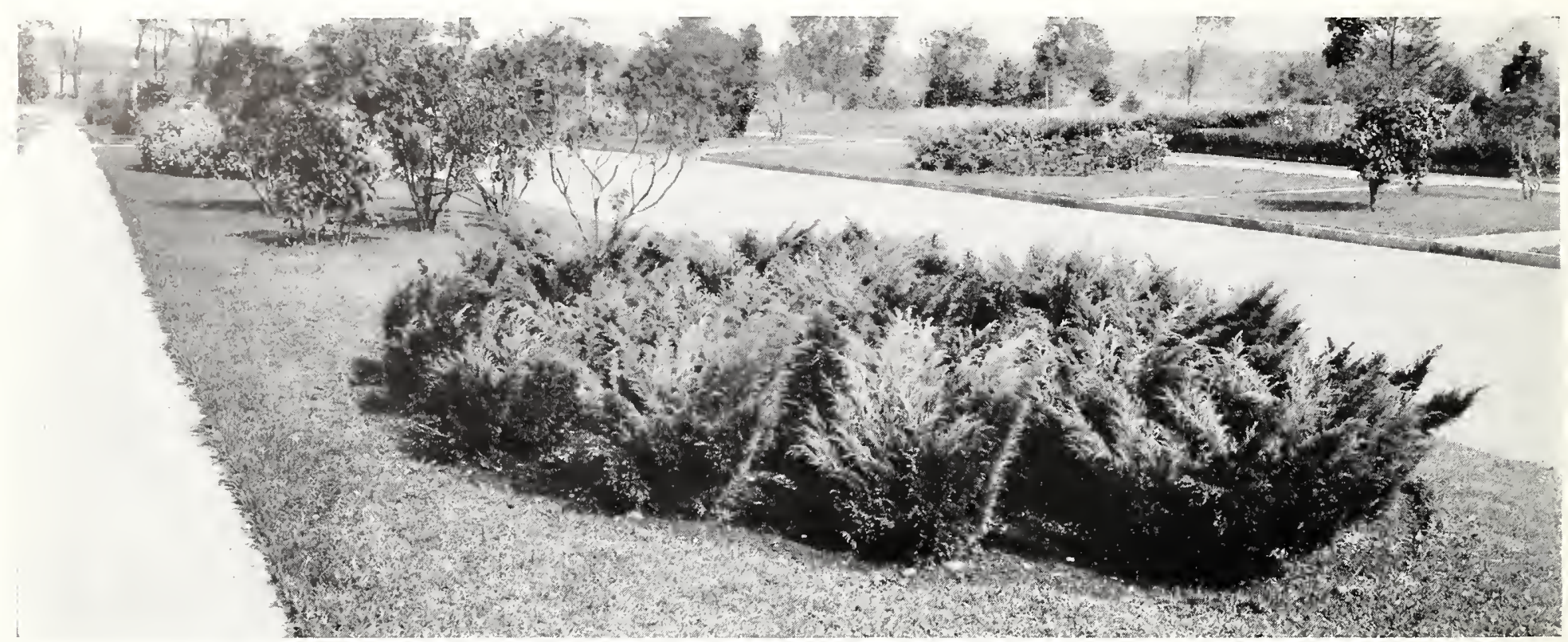

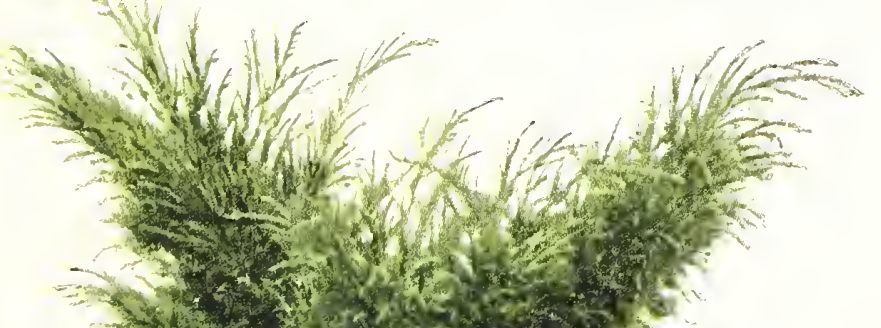

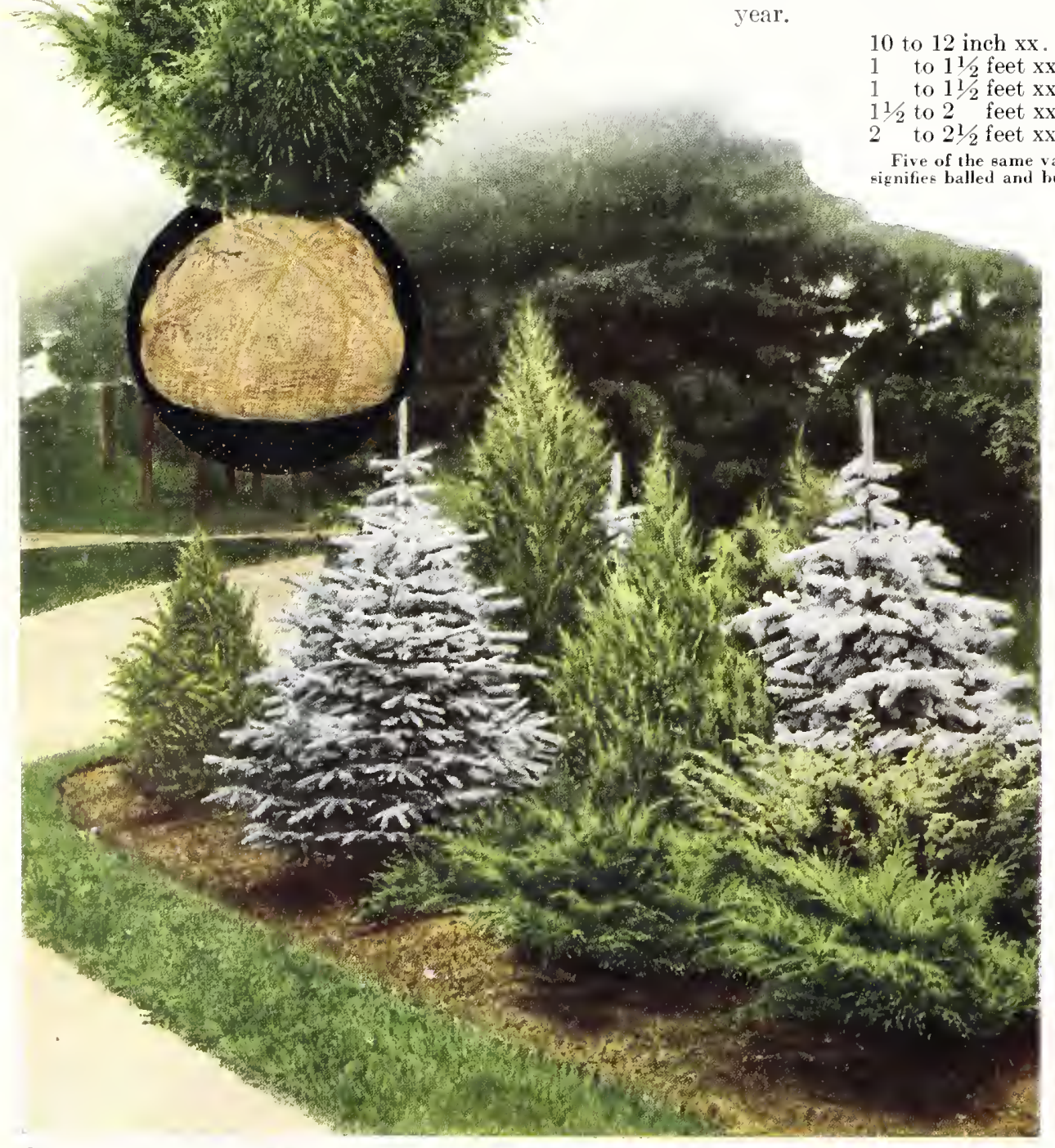

\section{Savin Dumiper}

(Juniperus sabina)

A Low, many-branched shrub, reaching a larger size in old trees. Its branches are spreading, dense, thickly covered with branchlets and heavily clothed with short, tufted foliage. The color is dark green at all seasons of the

$$
\begin{aligned}
& 10 \text { to } 12 \text { inch } \mathrm{xx} . \\
& 1 \text { to } 1 \frac{1}{2} \text { feet } x x x \\
& \text { Five of the same variety ant }
\end{aligned}
$$

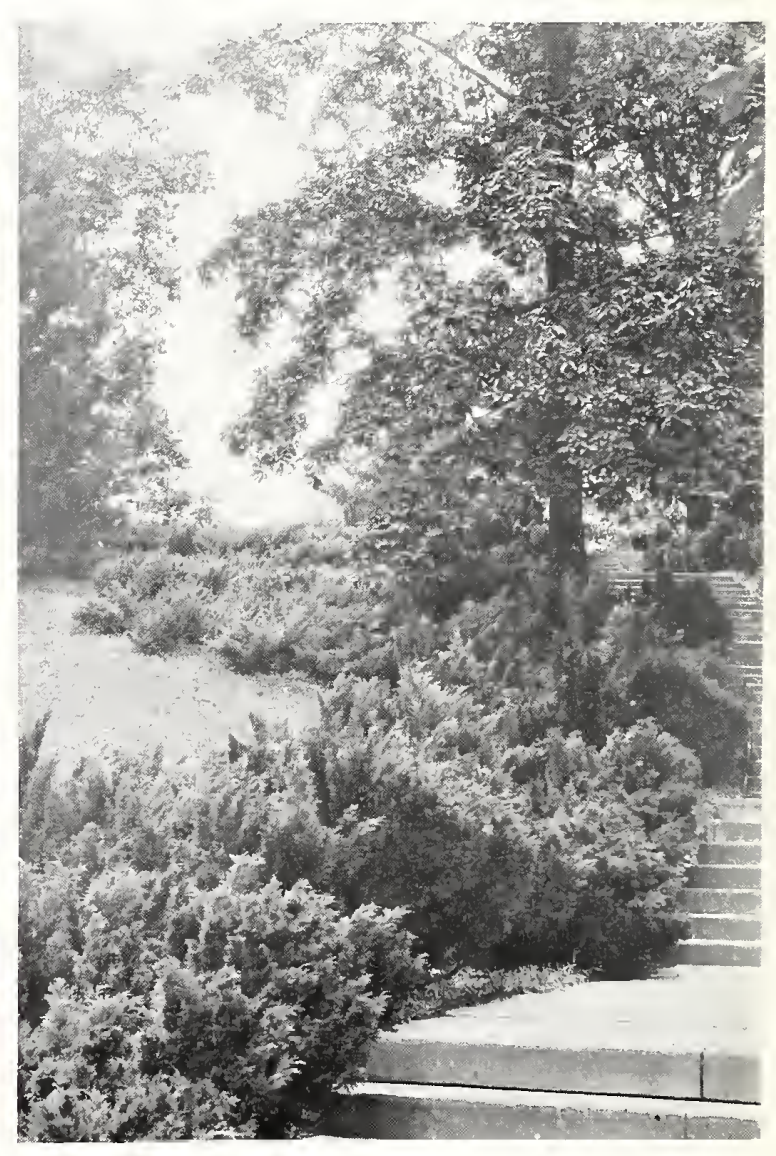

Bordering a ualk up the hill side, the Sat

The berries are blackish-purple or dark violet in color, some smooth and shining, some glaucous or powdery, all of them small, round, or oval, about the size of small currants.

It forms an excellent border to larger evergreens, and is also desirable as a low tree in foundation groups and for beds of Evergreens. Does well in smoky atmosphere. Can be easily trimmed and kept \begin{tabular}{crr} 
& EACH & \multicolumn{1}{c}{10} \\
B\&B & $\$ 1.50$ & $\$ 12.50$ \\
B\&B & 2.50 & 22.50 \\
B\&B & 3.50 & 32.50 \\
B\&B & 4.00 & 37.50 \\
B\&B & 5.25 & 50.00 \\
les one transplanting. & B\&B
\end{tabular} 


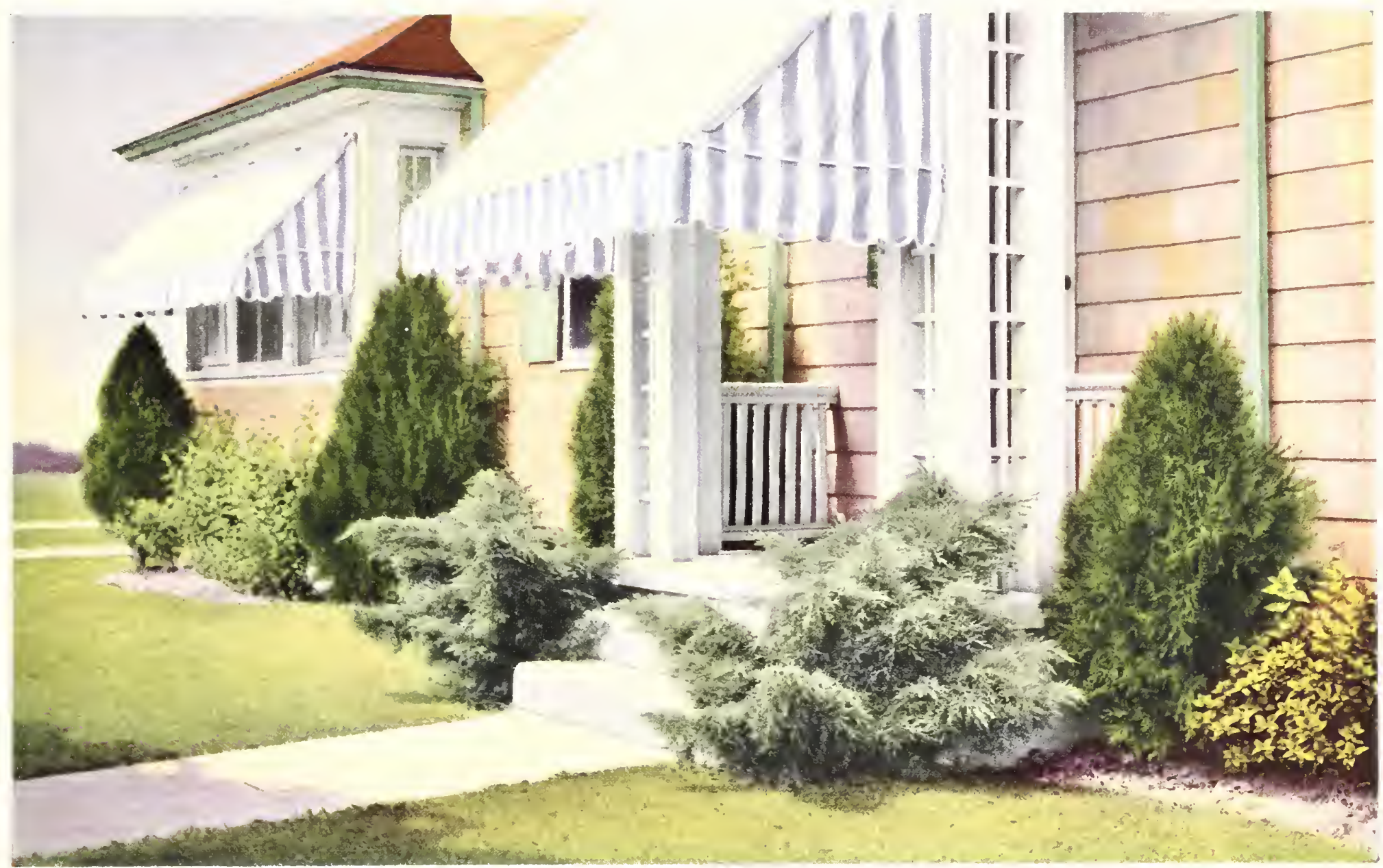

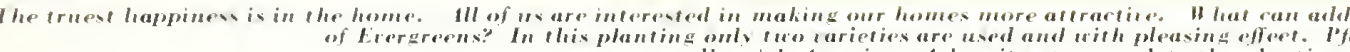

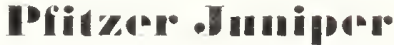

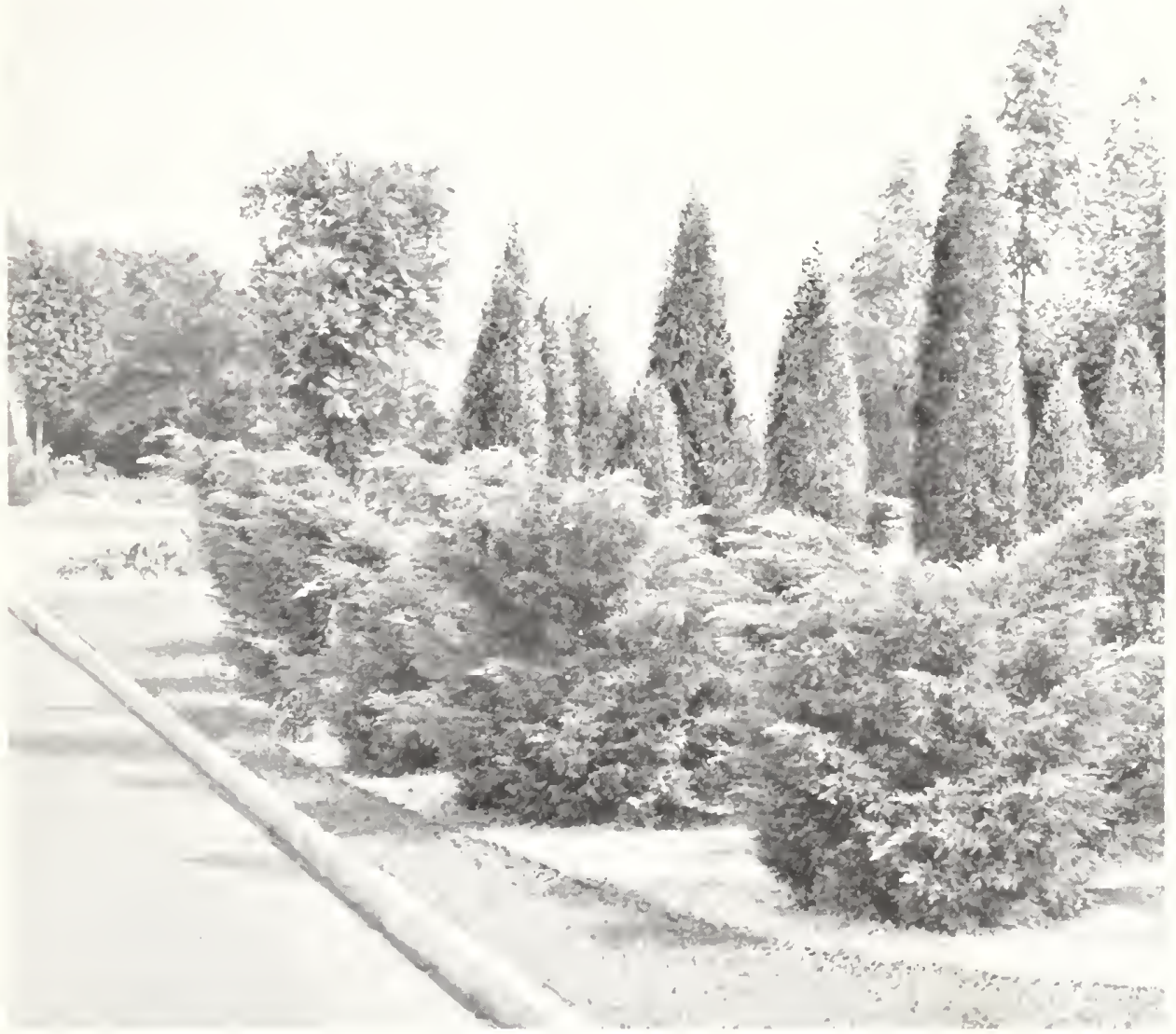

(Juriperus chinensis pefilzeriann)

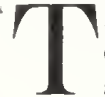
HE a low broad pyranid, is the most satifactory Arnold Arboretu

It was originated in Pfitzer's Jurery near Berlin, Germany, and introdueed to the trade by Ludwig spaeth, famous German nurseryman and horticulturist. ()nr original trees were obtained dineet from

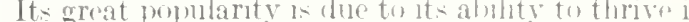
all parts of the country and undere almost any condigreens that will tand considerahle shate, making it foliage. We have dereloped a -train which to a dowe .

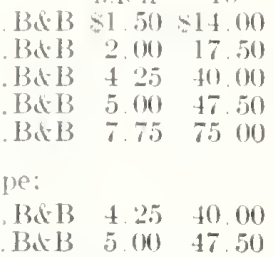



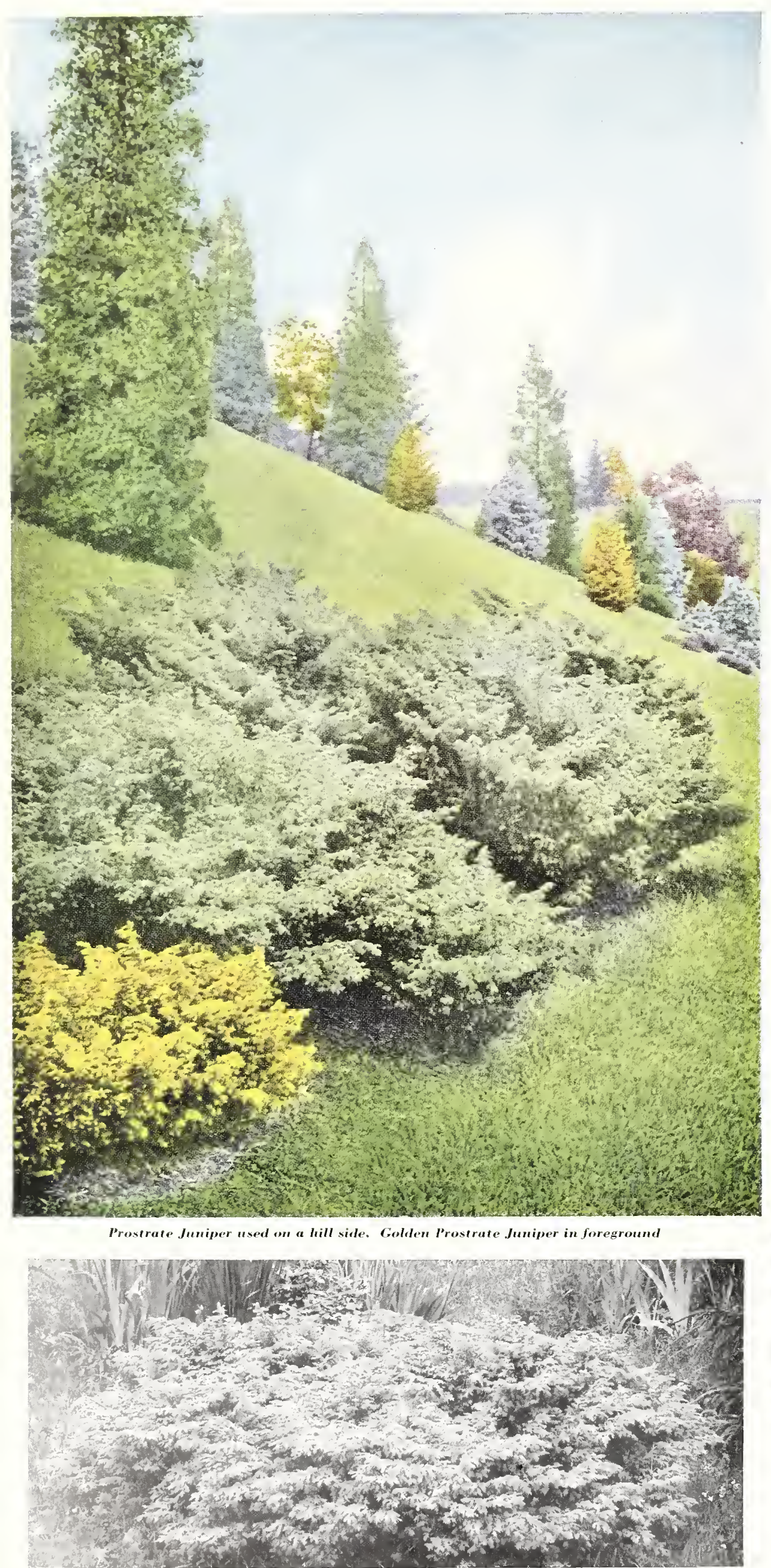

\section{Prostrante elmuiper}

\section{(Juniperus communis depresso)}

$\mathrm{N}$ old well-known tree, formerly called Juni-
perus canadensis. A very vigorous growing, 1 low spreading plant, having many stems. Old plants may extend seven or eight feet but it may be easily kept small by trimming. It grows very fast as compared to other Junipers. Rarely grows over three feet high, many plants grow even smaller.

The leaves are sharp pointed, gray-green above, silvery white beneath.

The berries are globular, smooth, shining, and dark purple in color, "azure studded." They mature at the end of the third year, when they are used for medicinal purposes and manufacturing of spirits. Evidence of this latter fact is contained in these lines of Tennyson:

$$
\begin{aligned}
& \text { The Birch Tree swang her fragrant hair; } \\
& \text { The Bramble cast her berry; } \\
& \text { The juice within the J uniper }
\end{aligned}
$$

It grows native over a wide area in eastern and northern America and varies somewhat in its habit, according to the locality. We obtain our seed from Wisconsin as we find this produces the best type. Planted 3 to 4 feet apart in a massed border, it forms an excellent frontage to a group of larger conifers.

$$
\begin{aligned}
& 1 \text { to } 1 \frac{1}{2} \text { feet } x x \\
& \text { B\&B } \$ 1.75 \$ 16.00
\end{aligned}
$$

\section{Golden Drositnate - Dnuipero}

\section{(Juniperus communis depressa ourea)}

7 HE golden form is very similar in habit to the green variety; the foliage, however, is a brilliant golden color, brightest in the spring and darkening during the year. Will make a bright spot of contrasting color among the darker Evergreens.

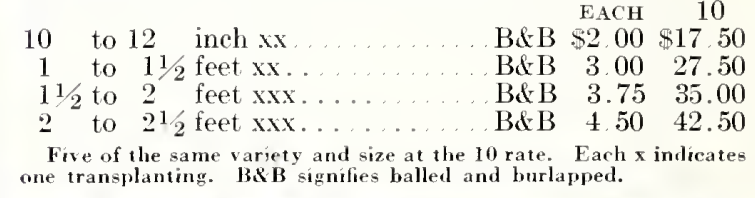

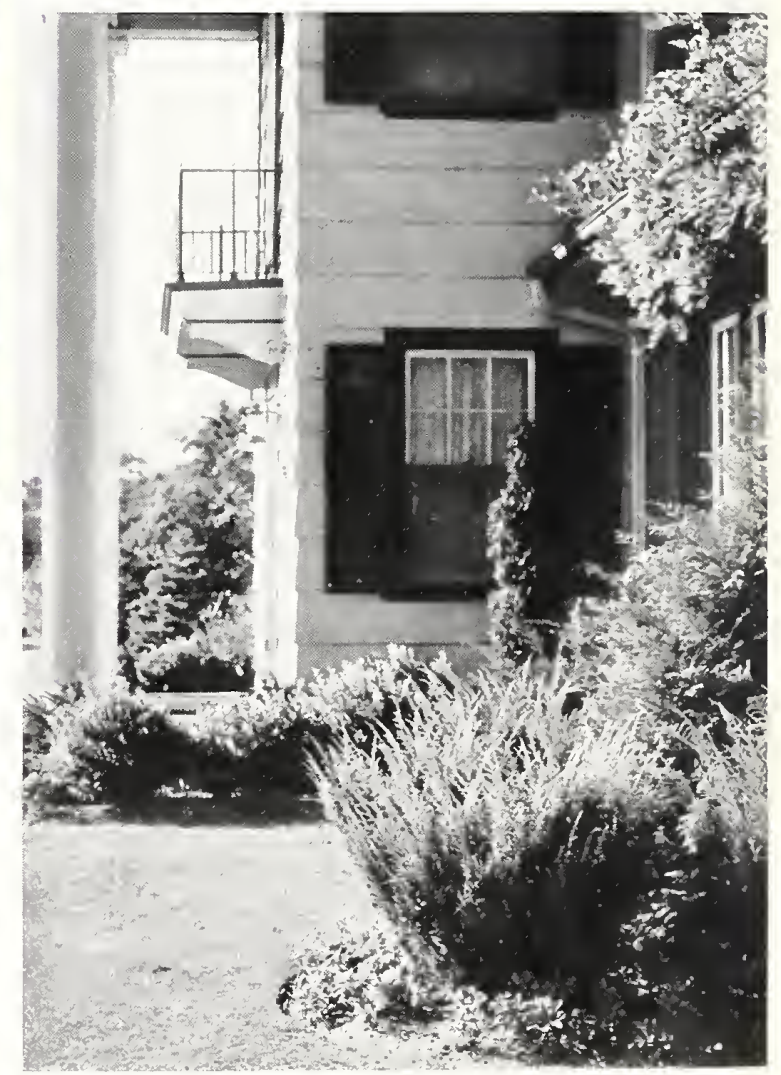

Prostrate Junipers make a good foundation planting tree, for 

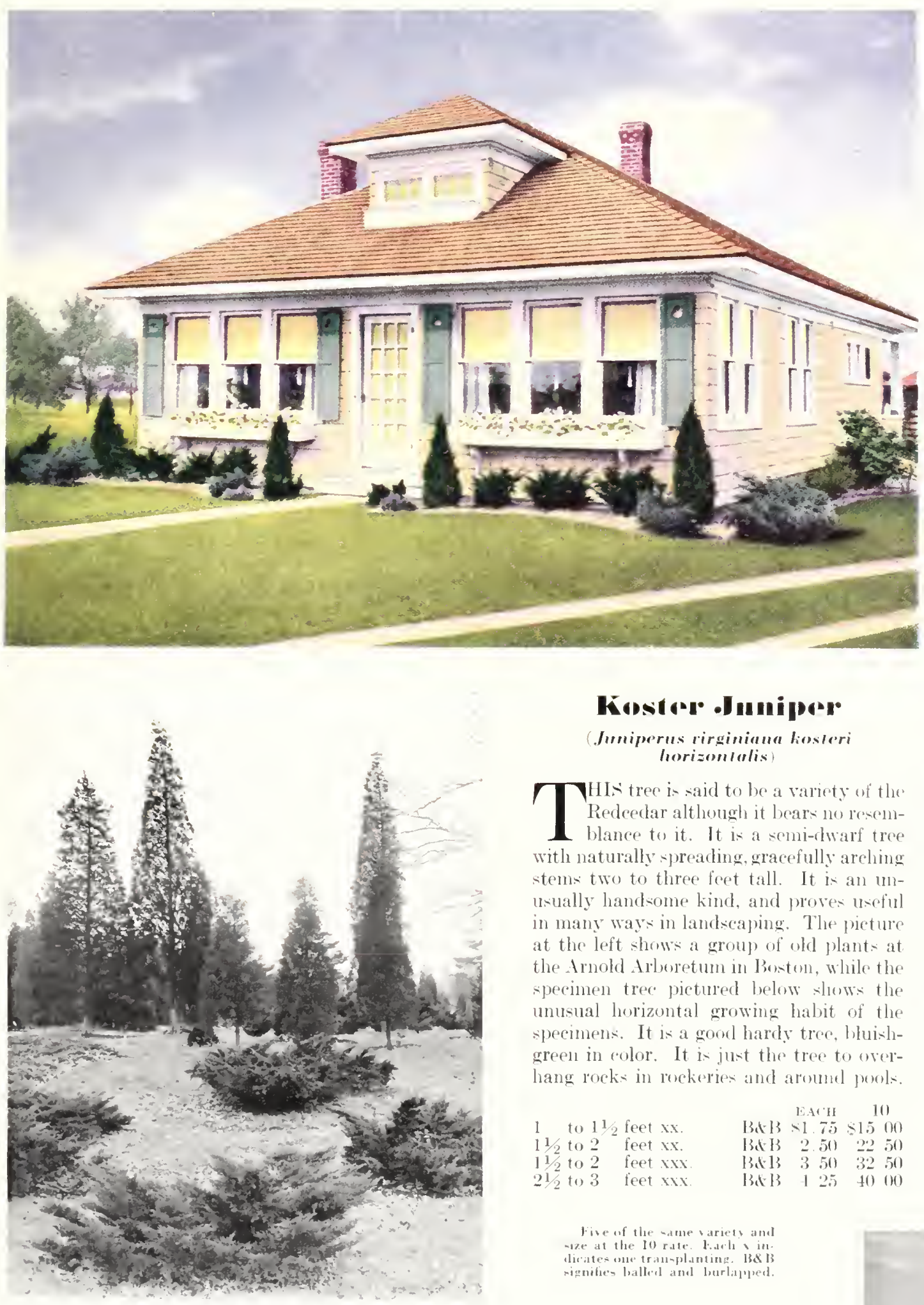

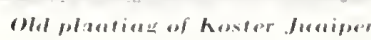

\section{Kosirer oluniper}

Jmiperus rirginiana liosteri horizomlelis

$\mathrm{T}$

THes tree is said to be a variety of the with naturally spreading, gracefully arching stems two to three feet tall. It iv an unusually handsome kind, and proves useful in many ways in landscaping. The picture at the left shows a group of old plants at the Arnold Arboretum in Bowton, while the specimen trec pictured below slows the unusual horizontal growing habit of the specimenk. It is a gook hardy tree, huishgreen in eolor. It is just the tree to orerhang rock: in reckeries and around pools. $11 / 2$ to 2 feet $\mathrm{xx}$. Bis $2.50 \quad 2250$

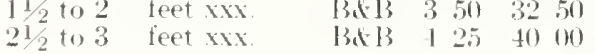
Redcedar although it bearw no resem-

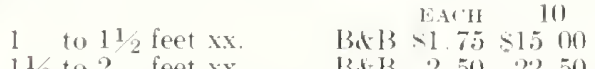

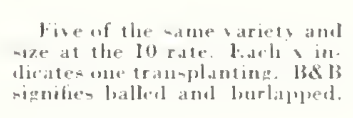

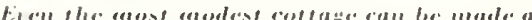

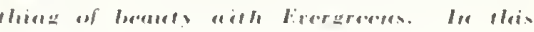

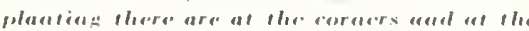

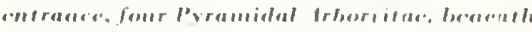

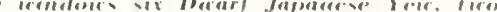

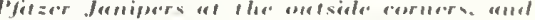

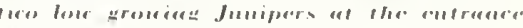

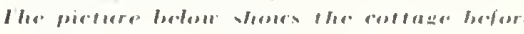

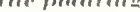

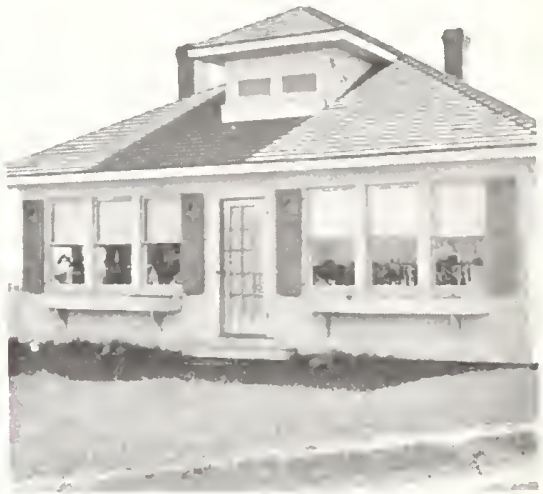

\section{Vaso-shaperl

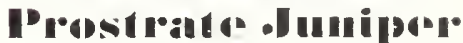

low IIIll Introdurlion

$\mathrm{T}$

NHIt tree is a variation of the prostrate Juniper shown on lage 1:2, sevelal years ago. It grows in a more crect

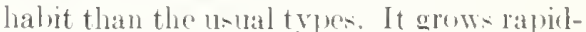
ly, keeps its rolor well and has no tenderey to show any injury from serere winters

Wr propagate this interesting tree from grafts anel ofier the only stoek available anywhele

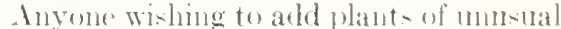
appearance ancl interesting forms will be glarl to use it in their lamelsater work. It has the characteristic grayi-h-green, mickIy neodles of the I'rostrate Juminere Jike other varieties of the commone. Juniper it thrives best in hot, rather dry locations.

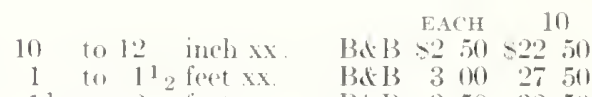

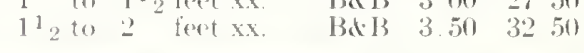

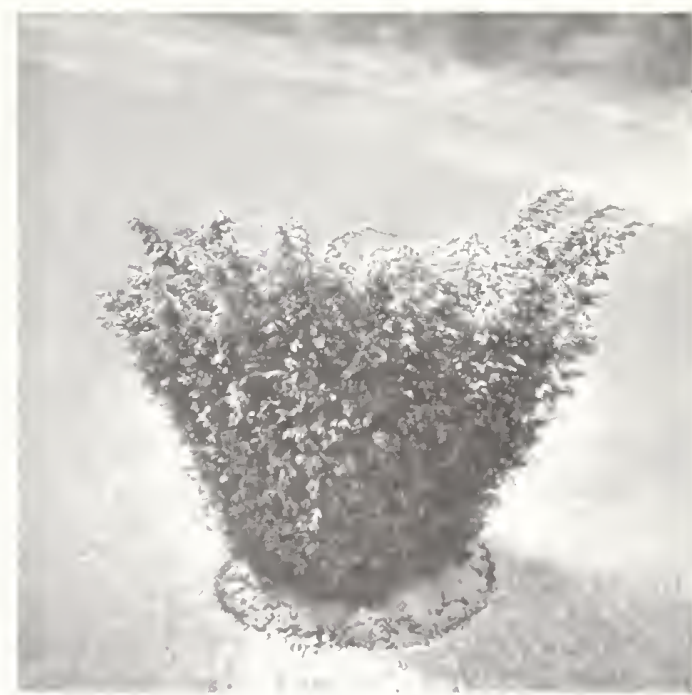




\section{Silver IRedcedar}

(Juniperus virginiana glauca)

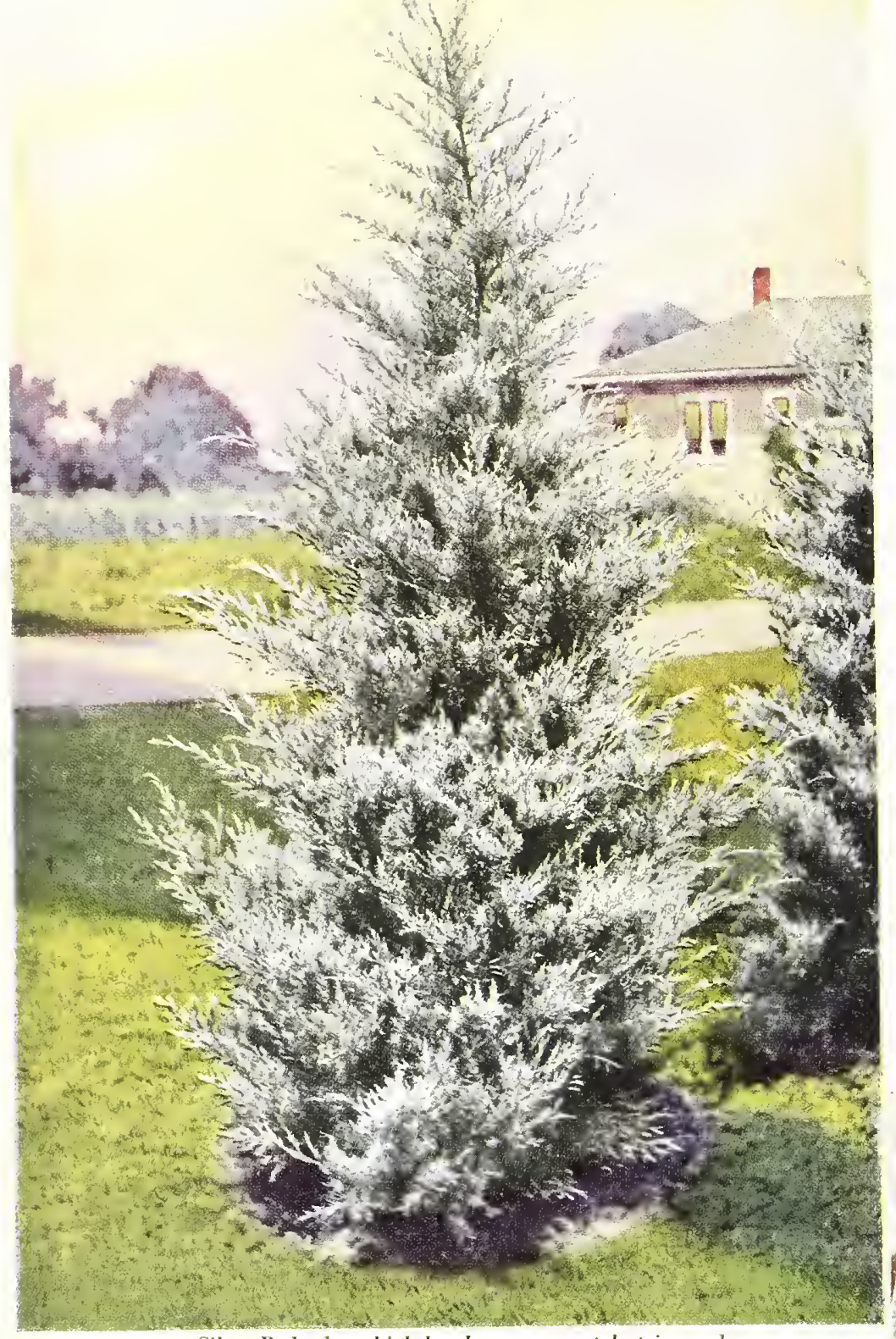

$7 \mathrm{HE}$ glaucous blue color, especially attractive during the Spring growing season, but of striking blue color at all seasons, makes it growth is rapid, the long, slender branchlets producing a graceful effect.

Different methods of trimming produce trees decidedly different in appearance. In the Hill Nursery, we trim the trees quite severely during the early stages of growth, thereby stiffening the branches and making the trees compact and uniform. Some planters prefer the more open growth, but in either case it fits in remarkably well in groups of other varieties. The ultimate size is 15 to 20 feet, although it may be maintained at much smaller size by trimming.

1 to $1 \frac{1}{2}$ feet $\mathrm{xx}$

$11 / 2$ to 2 feet $\mathrm{xx}$

2 to $21 / 2$ feet $x x$.

3 to 4 feet $\mathrm{xxx}$

4 to 5 feet $\mathrm{xxx}$

to 6 feet $x x x$

\begin{tabular}{rrr} 
& EACH & \multicolumn{1}{c}{10} \\
B\&B & $\$ 2.00$ & $\$ 17.50$ \\
B\&B & 2.50 & 22.50 \\
B\&B & 3.00 & 27.50 \\
B\&B & 4.50 & 42.50 \\
B\&B & 8.25 & 80.00 \\
B\&B & 11.50 & 110.00 \\
B\&B & 16.00 & 150.00
\end{tabular}

Five of the ane varinty and aize at the 10 rate. Fach $x$ indicates one transplanting Be B signifies balled and burlapped.

On an island in Lake Superior is this mute evidence of the tenacity of Evergreens. Perched on a barren rock with barely enough soil to hold on, this pine tree continues to make a yearly growth.

Evergreens are found growing under the most adverse conditions, overhanging the rocks at the seashore or high on the timber-line where their very existence is a constant struggle with the elements.

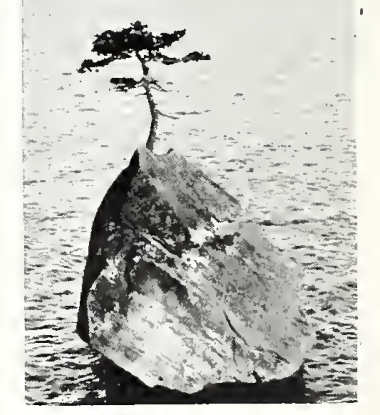

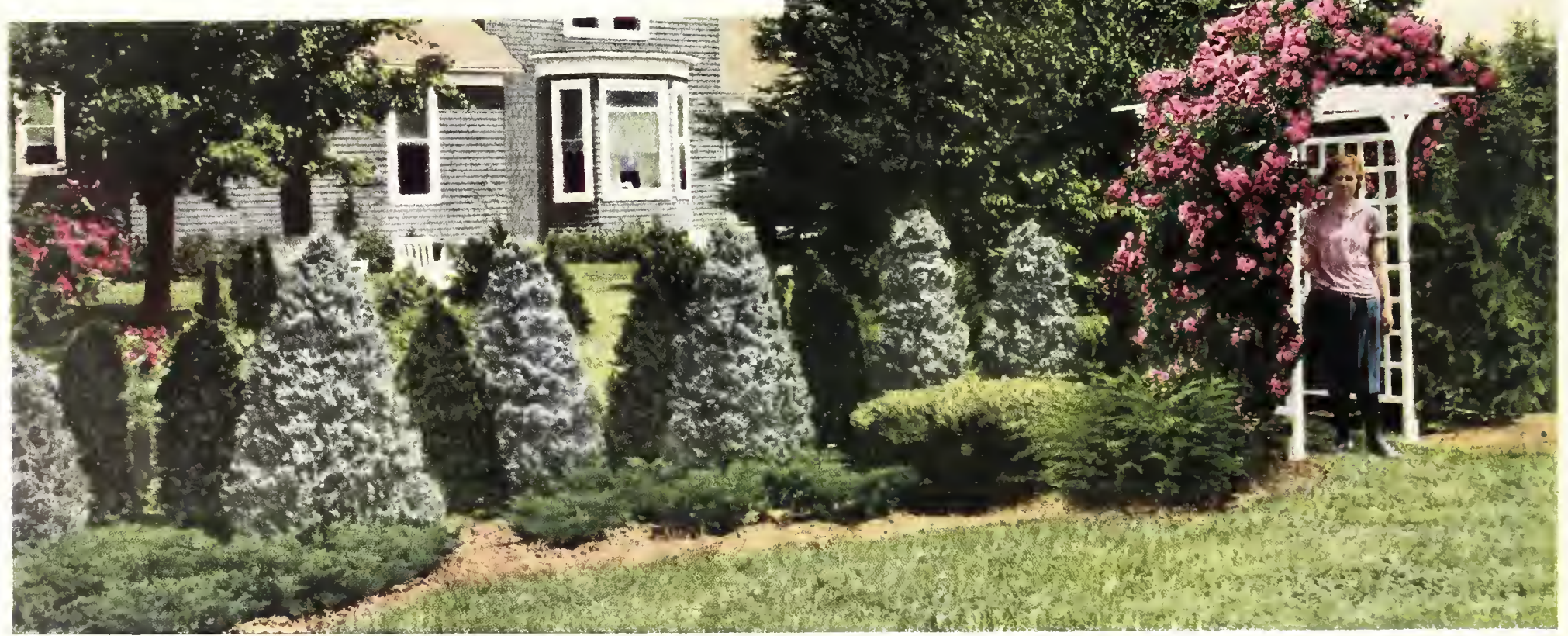




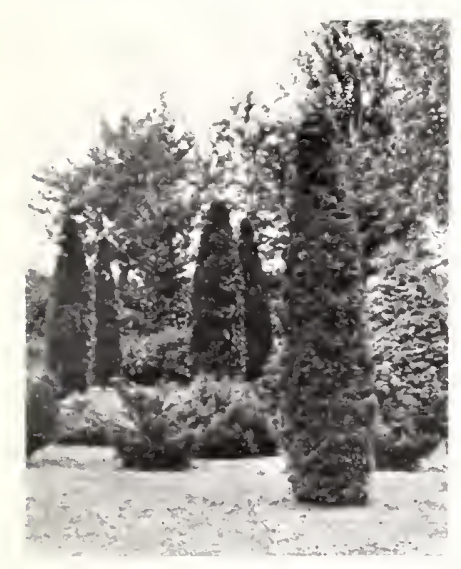

1s a lawn tres these trimmed perimosts of kededar provide an inof tree.

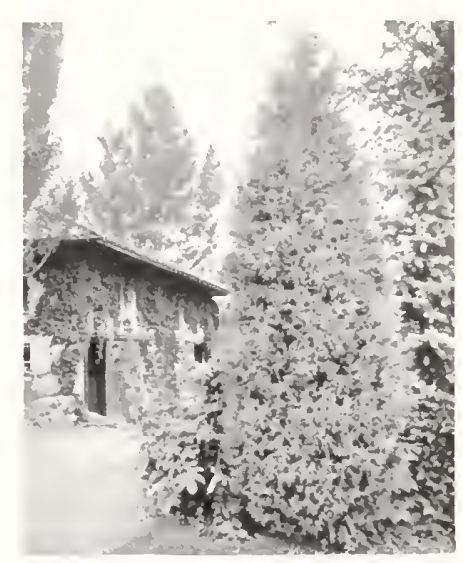

H hern allowed plests of roosn in the

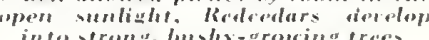

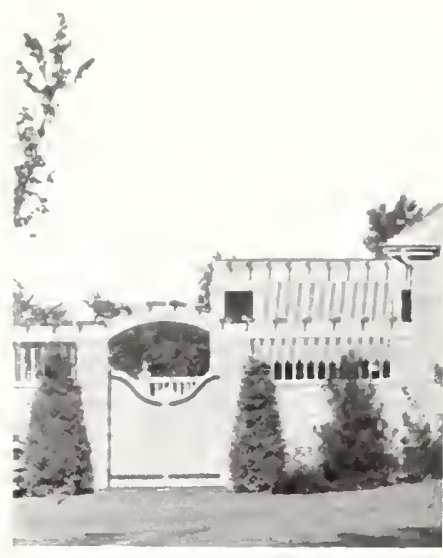

Bectuse of their compart and swm-

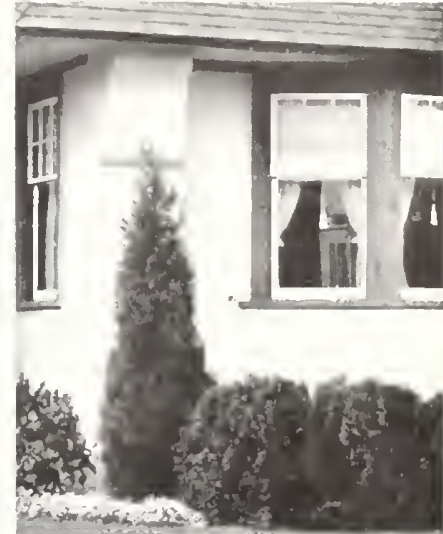

kedestars are appreperiate as the

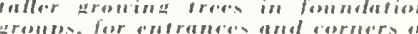

\section{IRa-alcoraliare}

\section{Juniperns riruinium}

$\mathrm{T}$ HE Redeedar is America's how artrerticed Evergreen. Ninture planted it over almost all the Jorth American continent. From the land of snow and ice, down through to the far south, it is found in a wild state in one form or another-tall and narrow trees, low and bushy trees, and all intermediate shapes are found in various localities. The type -lown in this picture, which we grow exchusely. is the narow, compact, pyramidal type.

As winter comes on, the tips of the new foliage present a pinki-h appearance and make a rery beautiful picture. The early spring color is very bright green, gradually darkening during the -nmmer.

Redeedar often grow naturally in aravelly hillsides, and is excellent for planting in poor, sandy wils. where it has plenty of circulation of air and sunlight. It is not a fast grower as compaled with some of the Pines and spruces, but makes. under farorable conditions, an annual growth of about eight incher.

The wool of Redcedar is an important enmmereial product. It is enpecially noted for it - ability to resist the eflects of moisture. It is aloo notable tor its fragrance, which helps to prevent the attackin of moths and, in consequence, it is much weed for clwetand chests.

The tree hear bright blue and silvery berrie- which are a great attraction to bird..

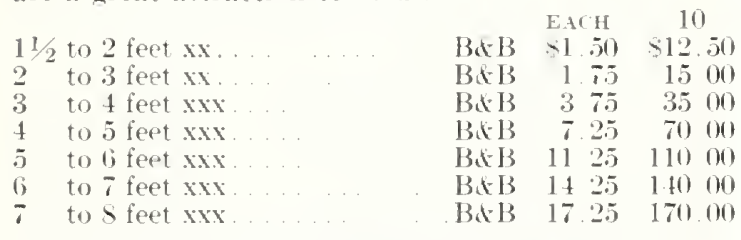

Five of the same variety and sise at the 10 rate. Fanly rindicatea
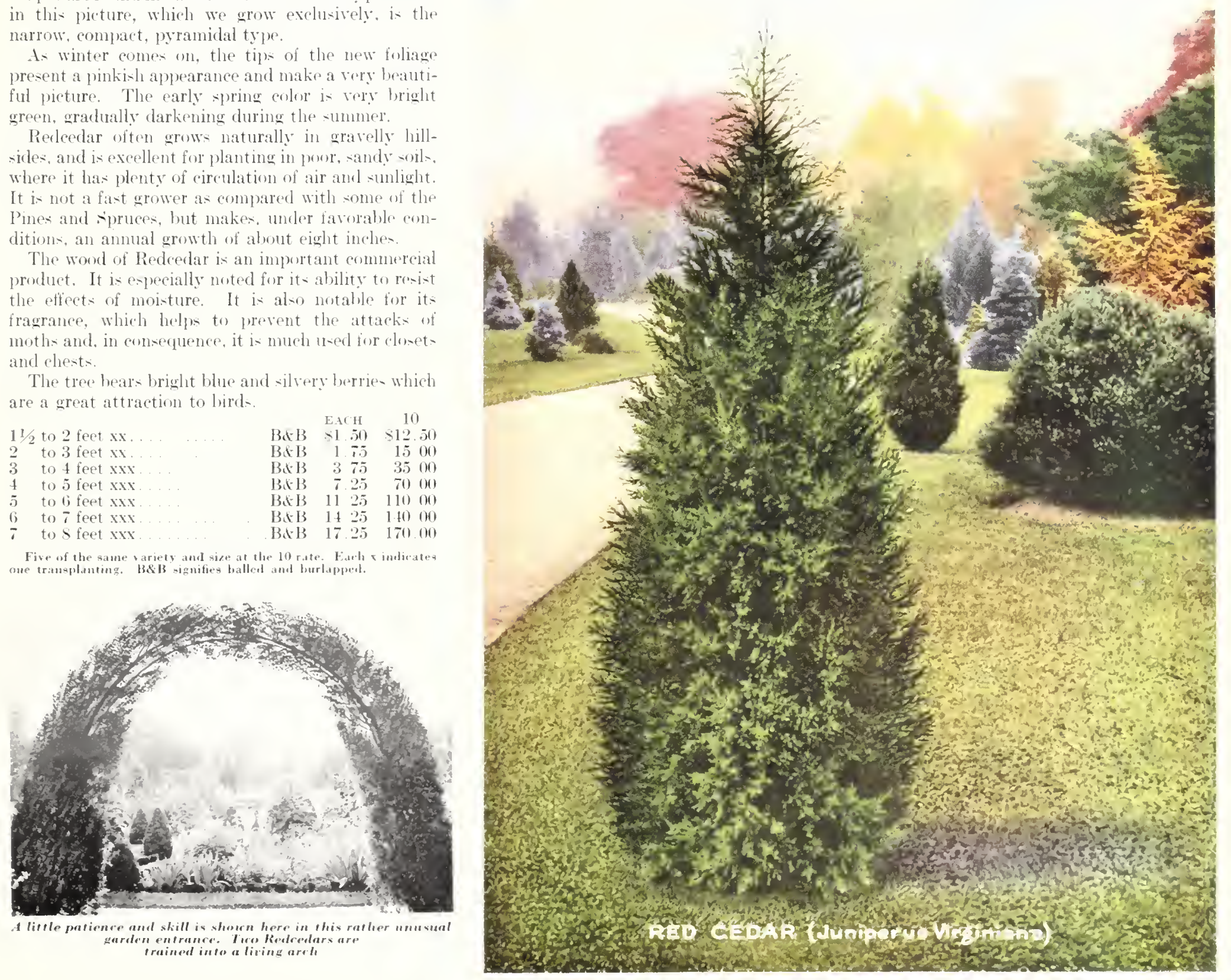

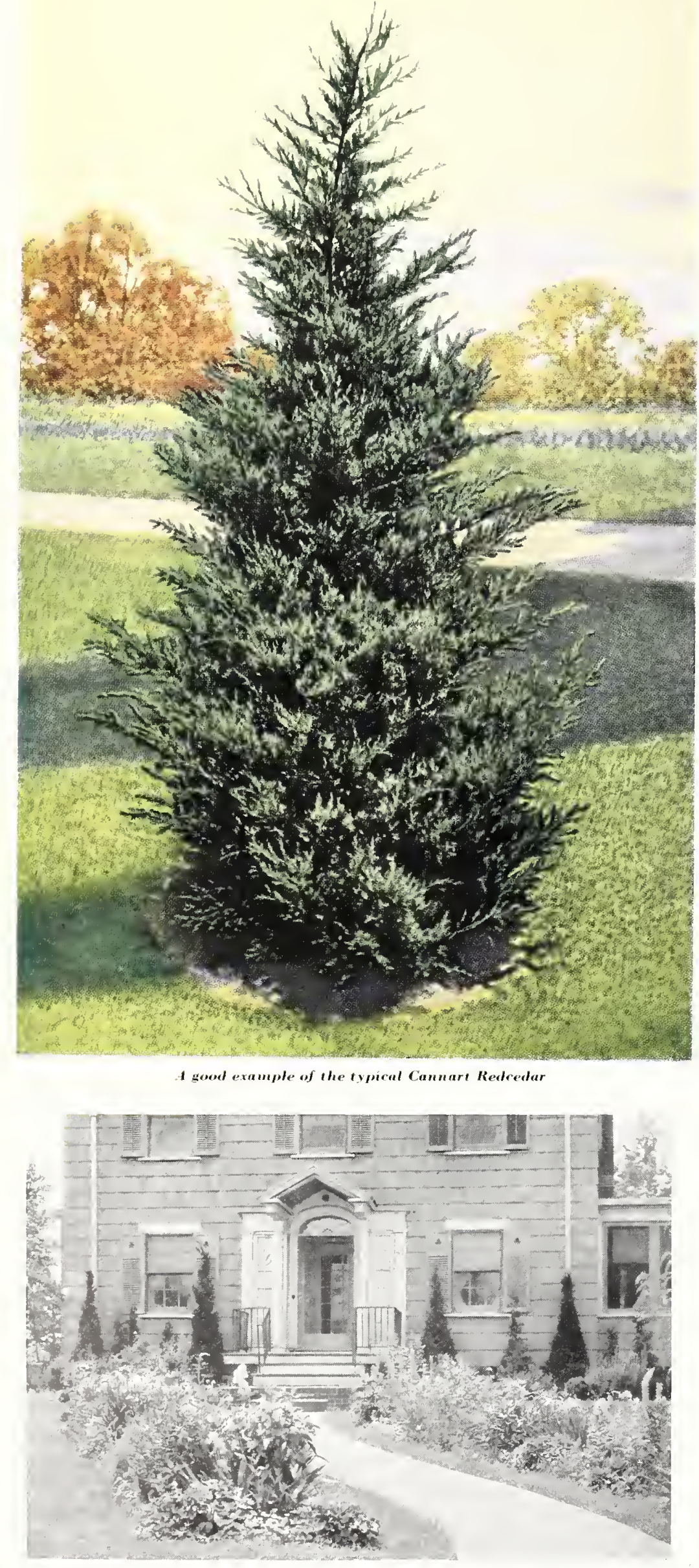

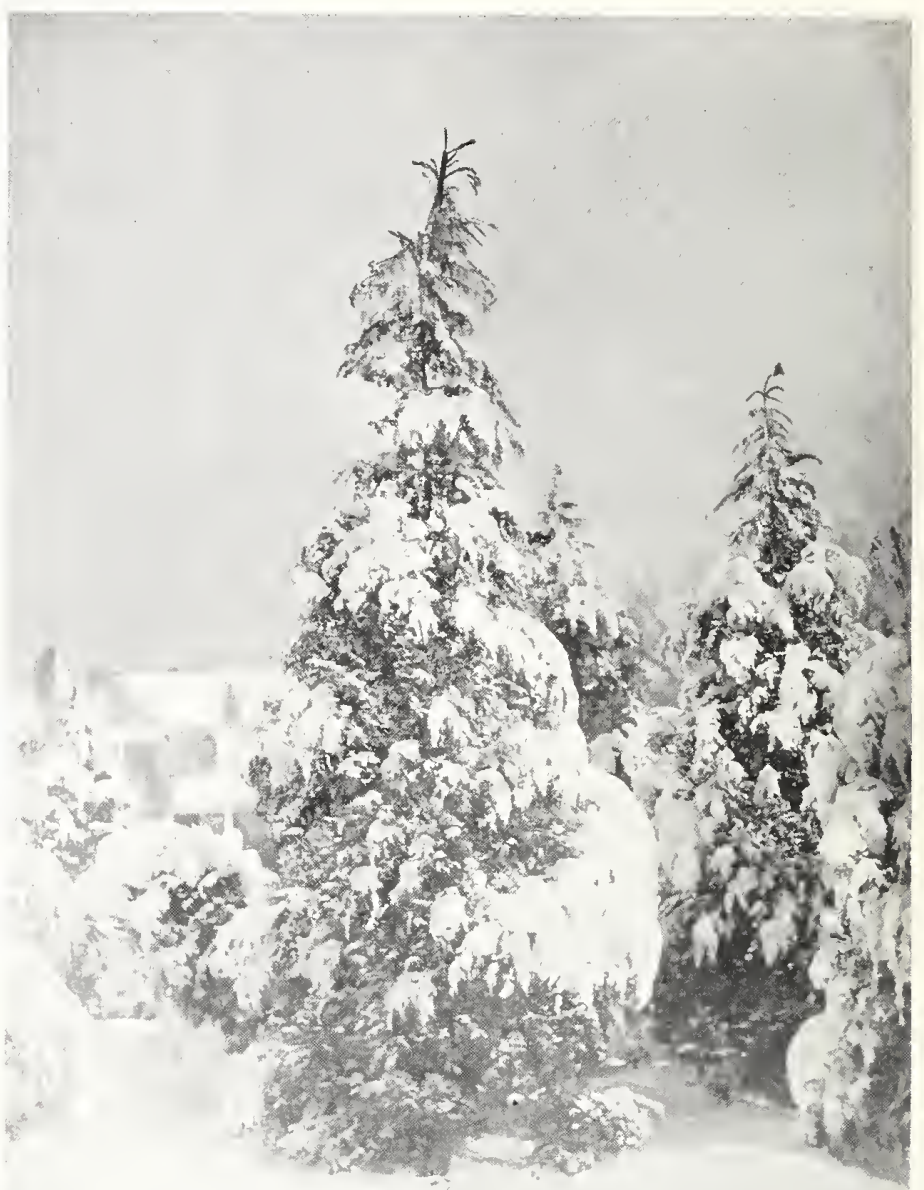

\section{Cammant IBedecedar}

(Juniperus virginiana cannarti)

$\mathrm{O}$ $\mathrm{TE}$ of the leading forms of Redcedar, having deep rich green, heavily tufted foliage. It makes a pyramidal specimen of middle size, reaching 15 to 20 feet. It can be readily trimmed and thus maintained at any size wanted. If left untrimmed, the growth is more or less open, but none the less pleasing.

Some trees bear blue and silver berries which adhere late in Autumn and are greatly enjoyed by the birds. An absolutely hardy tree, propagated by grafting.

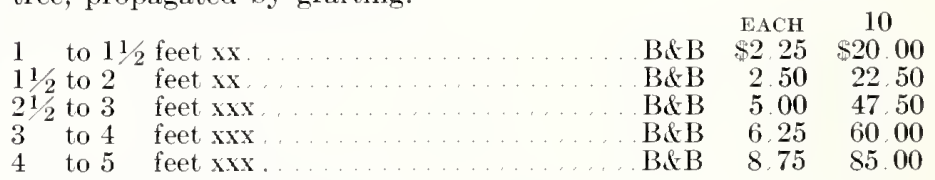

Five of the same variety and size at the 10 rate Each $x$ indecates one trans. planting.

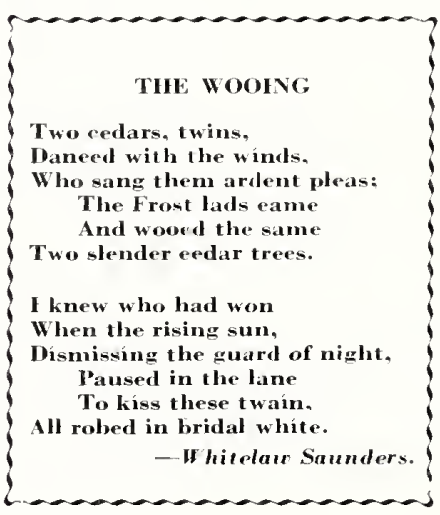




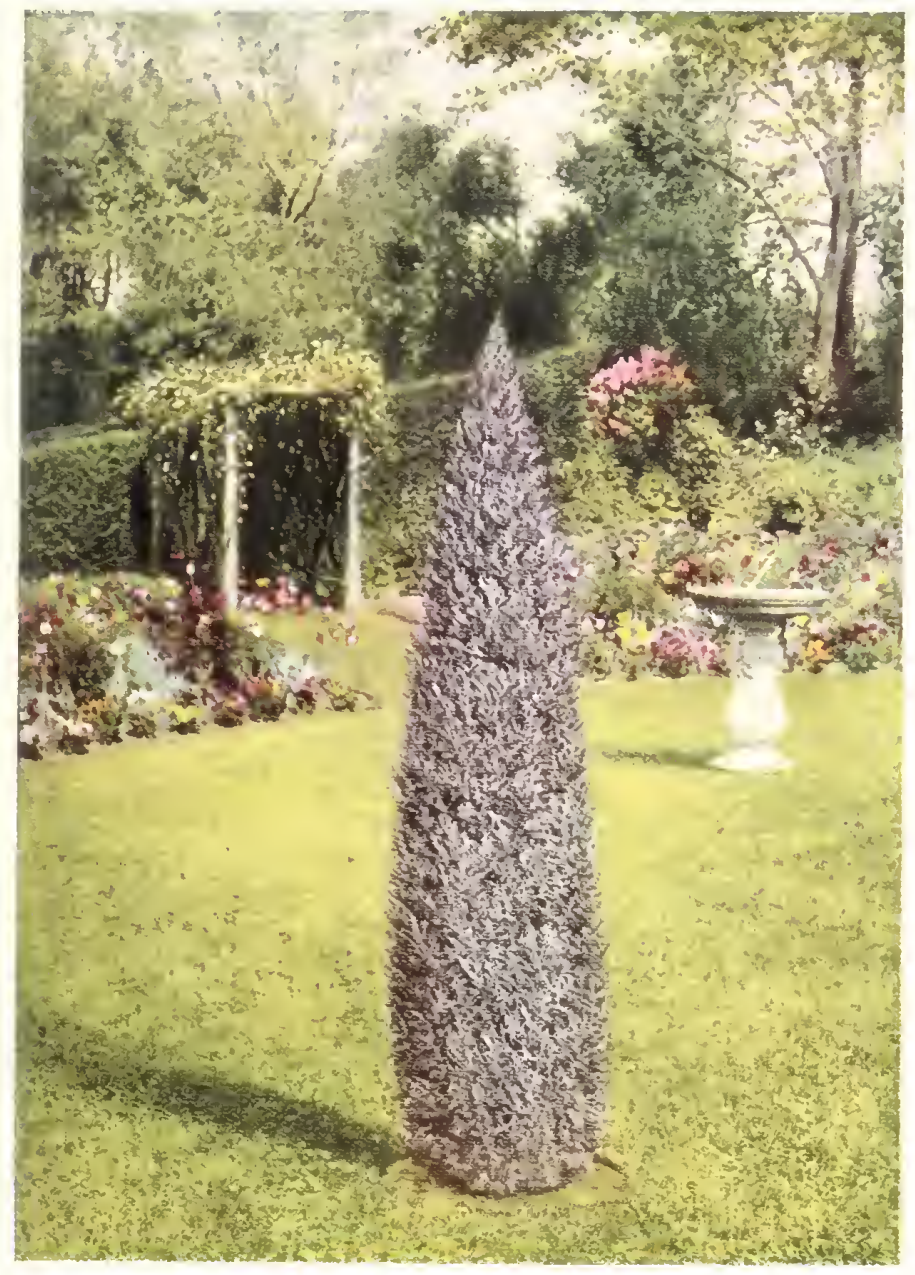

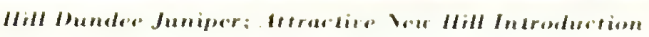

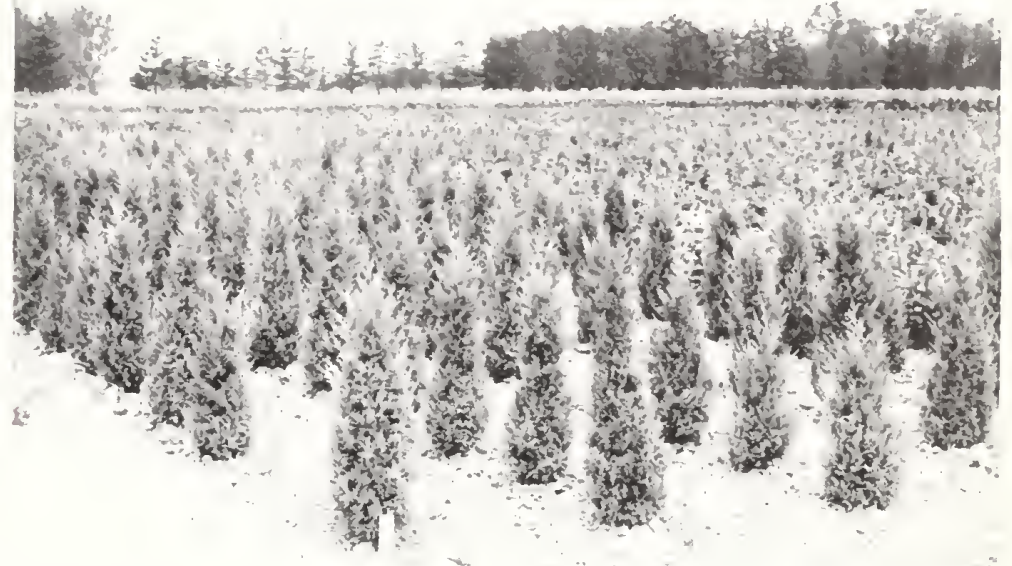

Mill Dumder . Inniper (Juniperus. virg, pyramidaformin

$\mathrm{T}$

Juniper.

It is bhish-gray in the spring and summer and it change- to a plum-like color in the Fall and Winter. This inot the bronze color of the Rerkedar. but a very unusual phum-like shade which is entirely different from any other Evergren. To create new intere-t in your Liereroen phantings you -hould inchule this most escollent new Juniper. Whibe it is of lecent introduction, we have had plants tested in different localities for the past ten vears so offer it with full assmance of it. dependability and satisactory development
1 to $1 \frac{1}{2}$ feet $\mathrm{xx}$.
$11 / 2$ to 2 feet $\mathrm{xx}$.
2 to $21 / 2$ feet $\mathrm{xx}$
3 to $3^{1 / 2}$ feet $\mathrm{xx}$
$31 / 2$ to $t$ feet $\mathrm{xx}$

\section{Sa-lioti IBedloedare}

(Jumiperus virginima sclotli)

A

'YRAMIDAL variety differing from it: mother plant, the Redcedar, principally not change color in winter but keeps its bright green foliage throughout the vear. The growth is compact and symmetrical and it stands trimming well. Reaches 15 to $20 \mathrm{feet}$

$\begin{array}{ll}11 / 2 & \text { to } 2 \text { feet } \mathrm{xx} \text {. } \\ 2 & \text { to } 21 / 2 \text { feet } \mathrm{xx} . \\ 2 & \text { to } 21 / 2 \text { feet } \mathrm{xxx} \\ 2^{1} / 2 & \text { to } 3 \text { feet } \mathrm{xxx} \text {. } \\ 3 & \text { to } 31 / 2 \text { feet } \mathrm{xxx} .\end{array}$

\begin{tabular}{|c|c|c|}
\hline & EAC'H & 10 \\
\hline$B \& B$ & $\$ 2.50$ & $\$ 225$ \\
\hline & 3.00 & 27 \\
\hline & 400 & 37 \\
\hline & 500 & 47 \\
\hline & 6.00 & \\
\hline
\end{tabular}

\section{Goldtip IRealcedar}

\section{Juniperus virginiana eleqantissima}

OOLTIP REDCEDAR never fails to W bring forth an exclamation of delight time. It comes out in spring with rich cream colored tips which gradually darken luring the summer and fall until it becomes almost the color of old gold

It eventually reaches 10 to 15 feet. The hranches have a slightly drooping tendency.

When small it forms a rather irregular sprearing tree, but has a tendency to gradually take on a pyramidal habit. It deserves a place anong the more choice and rare varieties for the finer landscape planting:

1 to $1 \frac{1}{2}$ feet $\mathrm{xx}$ $11 / 2$ to 2 feet $x i x$

Gotust Redicedar

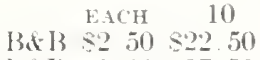
B.tB 3 (1) $27 \quad 50$ $\begin{array}{lllll}130+1 & 3 & 75 & 350 & 0\end{array}$

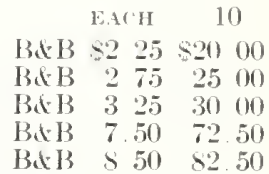

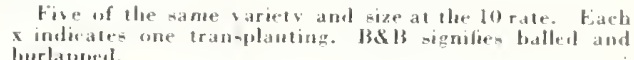
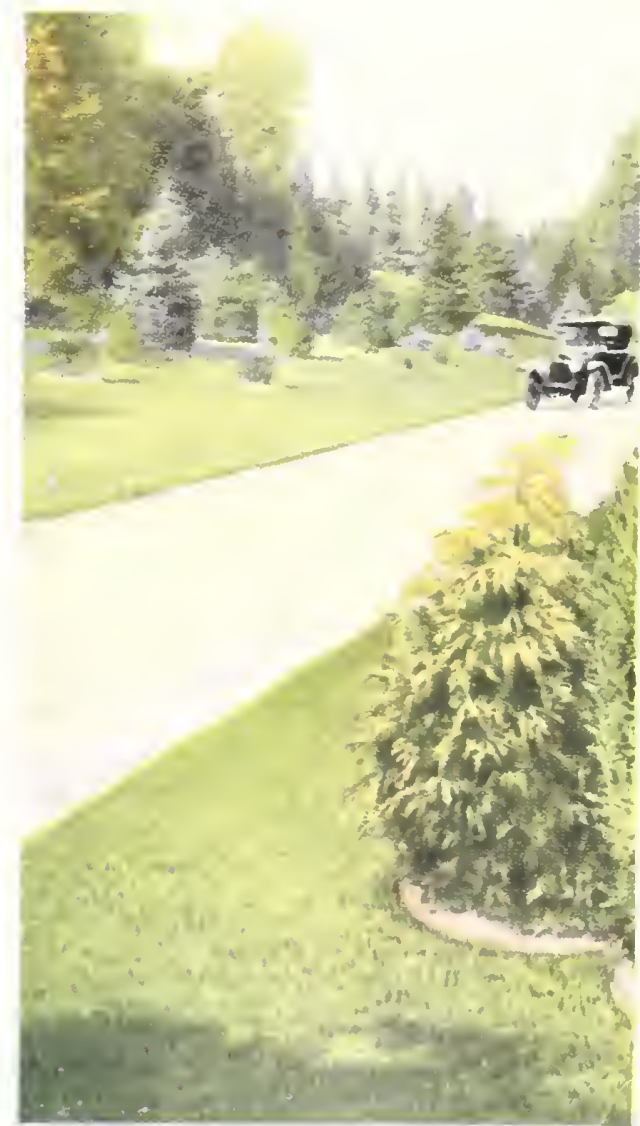


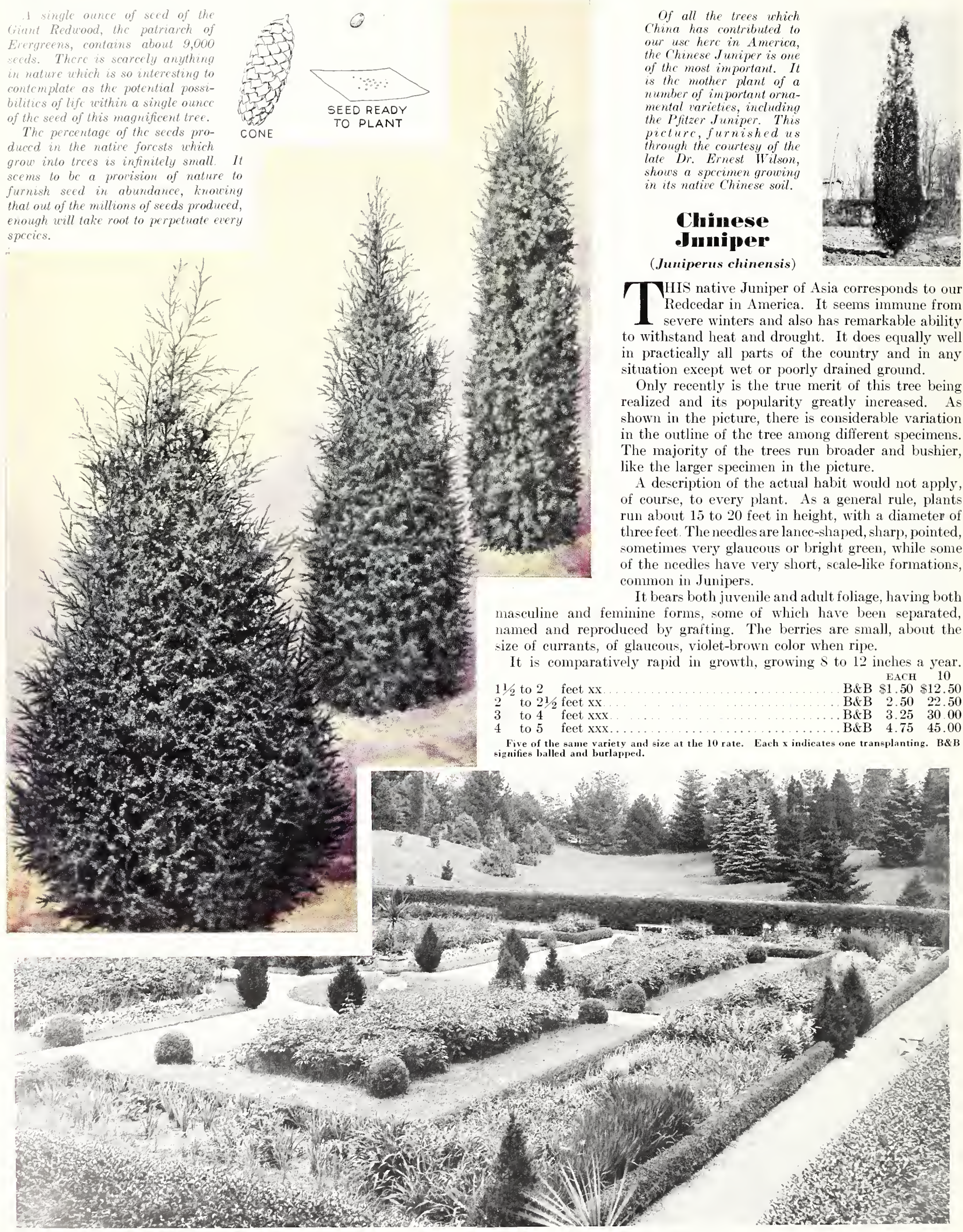




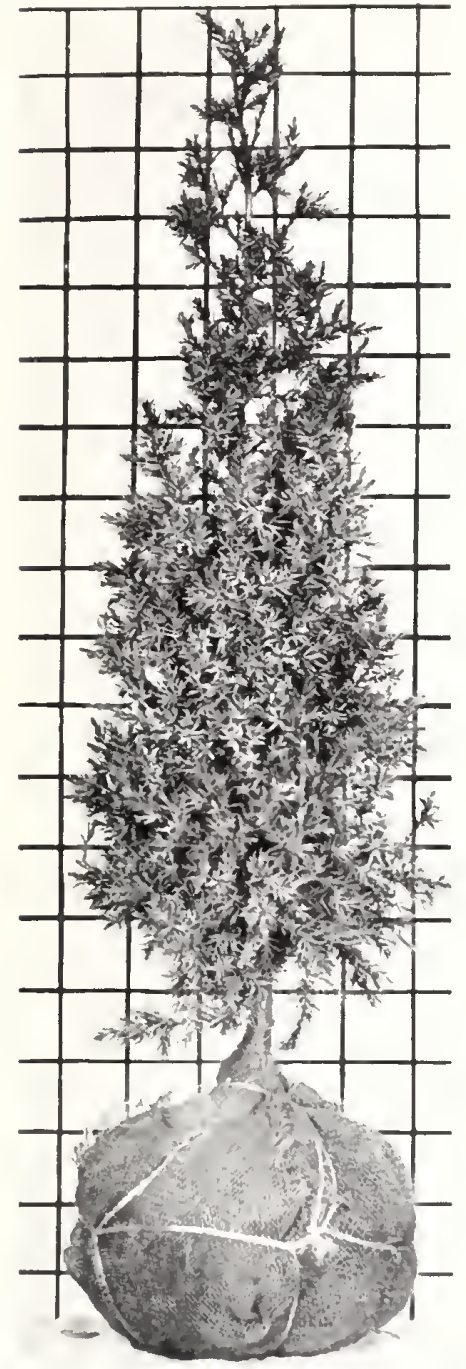

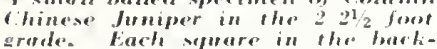
end is
1 small balled vereimen of coshmm

\section{Columu Chimeste - Inuiper}

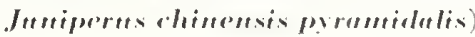

$\mathrm{T}$

DIIIs extremely narrow, cohmmar tree wats

first dicosered in ('lina ly the late lrank X.

Department of Igriculture. The tree in this picture is one growing in governmental ground * near $\|_{\text {its }}$ hington. 1). ( $C$ It show the true character of the tree when it reatehes full development. small phants, when recerved from the nursery, do mot have so nurrow a form, but develop the narrow whape at they grow older. There are two di-tinet forms of this tree, one having green foliage, the ot her, blue foliage. The illustration -how- the blue type

This tree reaches, appreximately, 20 feet in height when fully grown. It is a tree which is in demand to fill certain needs in landweape work, wheh an formal phantings, sentinele or accent trees. It will do well in almost any situation except in a too shatly loca-

The demand for this interesting tree is increasing each year. All IIill stork i- grafted, in-uring trees of good thrifty growth with abmondant roots. Trees propagated by other methods are oetdom wativfactory.
BLEE FORM

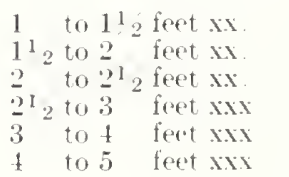

GREEN FORM

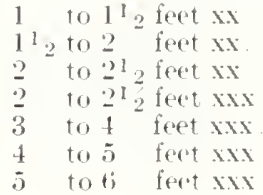

BS. B $\$ 1.75 \$ 1500$ 1384t3 $250 \quad 22.50$ BASE $3300 \quad 2750$

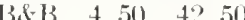
I3.813 $\quad 6.50 \quad 6250$ B.EB $\quad 950 \quad 92.50$

IB. BS\&T3 $2.00 \quad 17.50$ $\begin{array}{lllll}B A B & 2 & 50 & 22 & 50\end{array}$ Bis B +2540.00 $B \times B \quad 6256000$ $13.513<25>000$ $\begin{array}{lllll}B \& B & 10.25 & 100.00\end{array}$

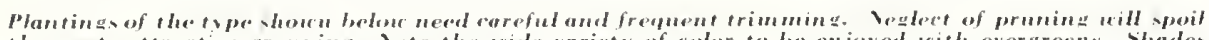

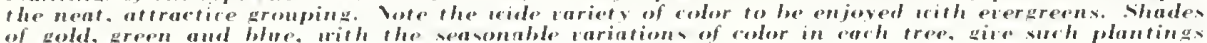

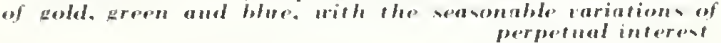

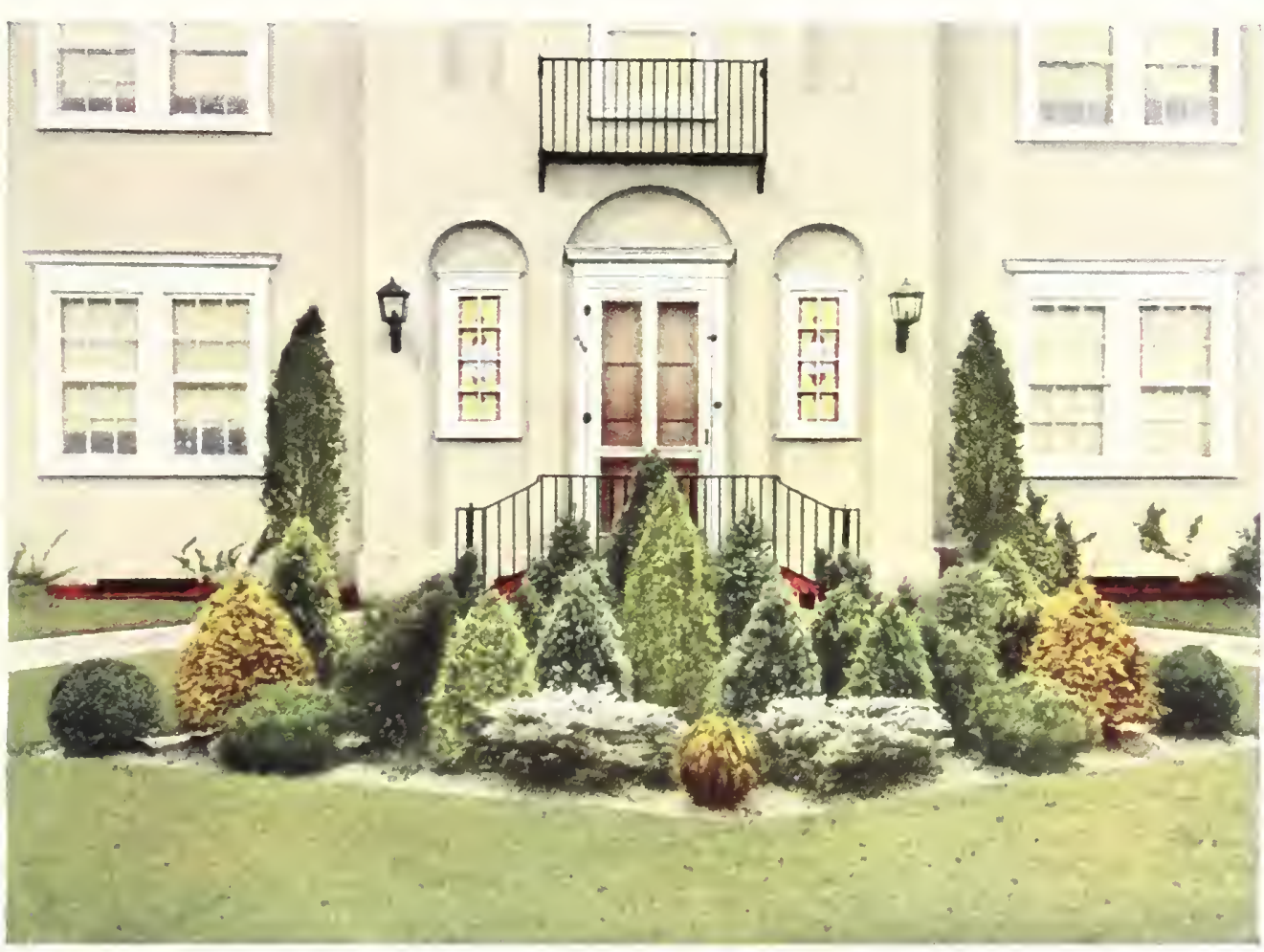

FVTRIYCE PLAVTIG COLLECTOS

This unisue and attractive planting mav be duphicated on your ground with the following trees. Key for planting shown in colored picture at the left:

(1) 2 Woutwart Globe Arborvitite $15 \times 15$ inches

(2) 2 Douglis Golden Irborvitar $2-21_{2}$ feet

(3) 2 Hitl Mlughe P'ine 15x15inche

(4) 2 Hill Wiukegan Junimer 1-11.2 feet

(5) 1 Globosia . Irborvitite _ 15x15inches

(6) 4 Cannart Redectar

(7) 2 Blate Ilill iprume

(s) 1 Redcedar.

(10) 2 Potzer Jumper

(11) 1 Climme Junner

(12) 2 Imerican Irborvitat

$2-3$ feet 15 foret

$1+2-1$ feet

$1-11_{2}$ feet 34 ifeet 


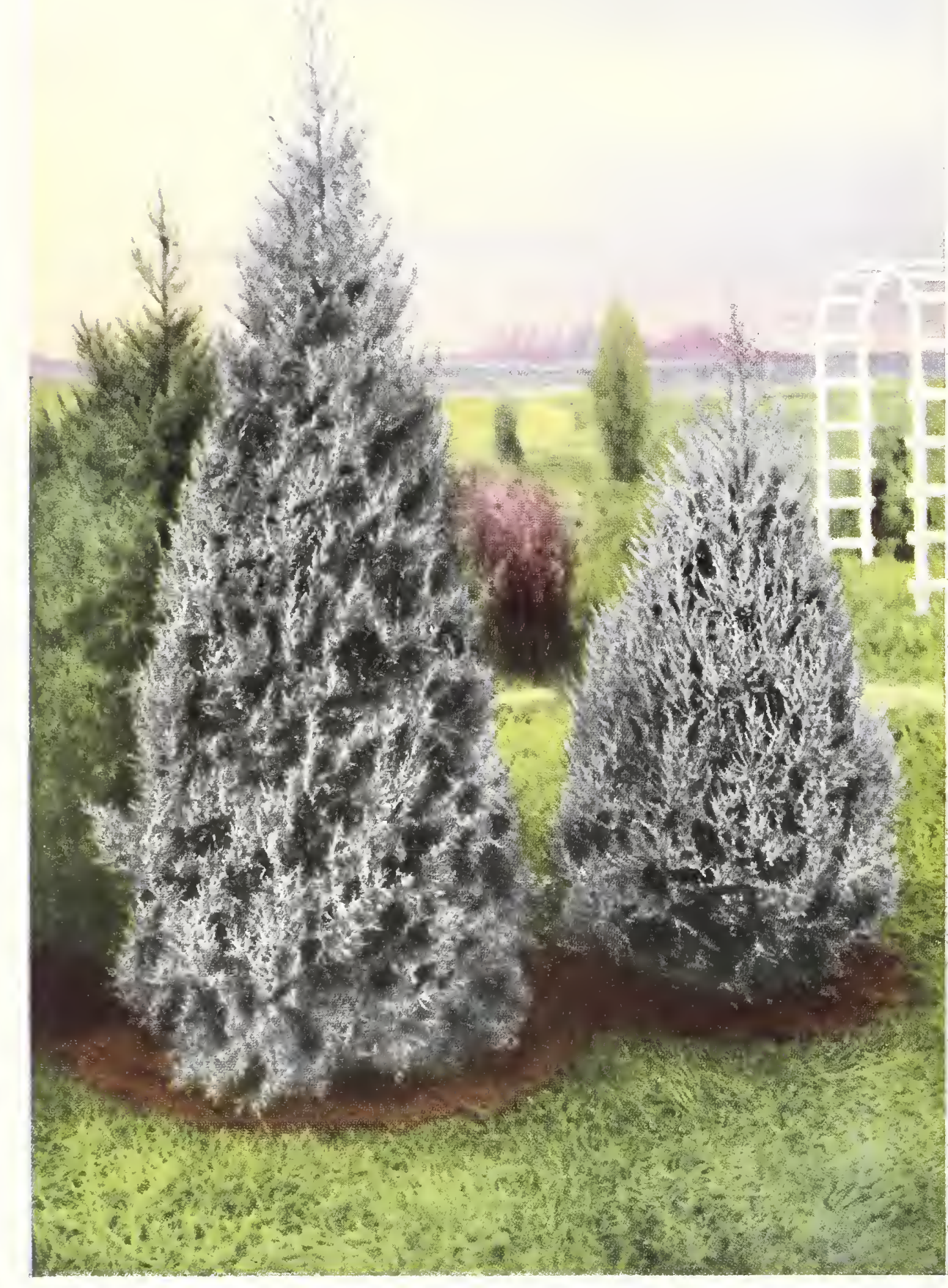

Hill Silver Juniper

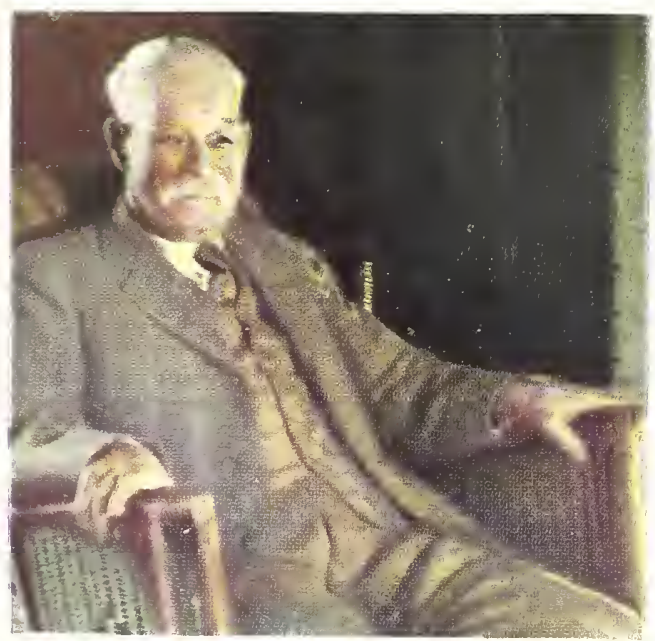

THE LATE D. HILL

whose recent death at 83 , brought to a close a lifetime of devotion to Evergreens.

One of his most particular interests was the development of new varieties of the Colorado Juniper as described on this page.

He made regular trips to Europe where he visited many nurseries in England, Holland, Belgium and France. Such trips never failed to develop a new variety or two. From a beginning of three or four varieties he finally built up a stock of scores of varieties. His original nursery of five acres expanded to six hundred acres and his business extended long before his death into every state and to foreign lands.

\section{IIII Silver Iuniper}

\section{(Juniperus scopulorum hilli)}

\section{NEW HILL INTRODUCTION}

$\mathrm{N}$

O such beautiful Junipers of real outstanding features have ever been offered to the nursery trade. This tree and the two other forms below will be a great delight for anyone, who appreciates new additional and dependable varieties.

The Juniperus scopulorum was a hobby of the late D. Hill. He experimented with these trees for twentyfive years having nearly two dozen forms at various times. He tested them thoroughly for hardiness and found them well suited for both the extreme south and north of the United States. In color and form they are without comparison among all Junipers.

The Hill Nursery originated these trees and is the only source of supply for the genuine choice Hill introductions.

The Hill Silver Juniper is the whitest blue Juniper obtainable. The silver foliage is magnificent. The color is brightest during the summer. It grows fast, bushy, and develops a shapely form as shown in this picture.

$$
\begin{aligned}
& 1 \text { to } 11 / 2 \text { feet } \mathrm{xx} \text {. } \\
& 11 / 2 \text { to } 2 \text { feet } \mathrm{xx} \text {. } \\
& 2 \text { to } 21 / 2 \text { feet } \mathrm{xx} \text {. } \\
& 21 / 2 \text { to } 3 \text { feet } \mathrm{xxx} \\
& 3 \text { to } 31 / 2 \text { feet } \mathrm{xxx}
\end{aligned}
$$$$
\mathrm{EACH} \quad 10
$$

B\&B $\$ 2.00 \$ 17.50$

$\begin{array}{lll}\mathrm{B} \& \mathrm{~B} & 2.50 & 22.50\end{array}$

B\&B $3.25 \quad 30.00$

B\&B $5.25 \quad 50.00$ B\&B $6.25 \quad 60.00$

\section{MOONLIGIT JUNIPER}

This is an extremely blue form having all whip-cord foliage with no needles. It is a spectacular novelty unlike any other Juniper.

EACH $\quad 10$

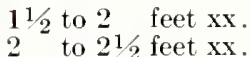

. B\&B $\$ 3.50 \$ 32.50$ B\&B $\quad 4.00 \quad 37.50$

\section{BLUE MOON JUNIPER}

This is a broad pyramidal form of silvery-blue color, with fine delicate foliage.

EACH 10

1 to $11 / 2$ feet $\mathrm{xx}$.

. B\&B $\$ 3.00 \$ 27.50$

2 to $2 \frac{1}{2}$ feet $\mathrm{xx}$. B\&B $\quad 4.00 \quad 37.50$

\section{Colorado Jumiper}

(Juniperus scopulorum)

I $\mathrm{N}$ its native home the Colorado Juniper covers a wide range extending from Colorado north to Montana and the Black Hills of South Dakota. Under the name "Colorado Juniper," we offer the seedling form, which is quite variable in habit and color.

Most trees are of a silvery color and close symmetrical, upright growth. It thrives in hot dry weather, when the color is brightest. It has a single stem or trunk, so that it is not easily injured by snow and ice. It retains its inner foliage well and keeps good shape as it grows. 12 to 15 feet is about the maximum height.

EACH 10

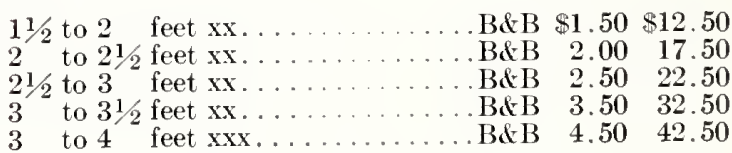

Five of the same variety and size at the 10 rate. Each $x$ indicates one transplanting. B\&B signifies balled and burlapped. 


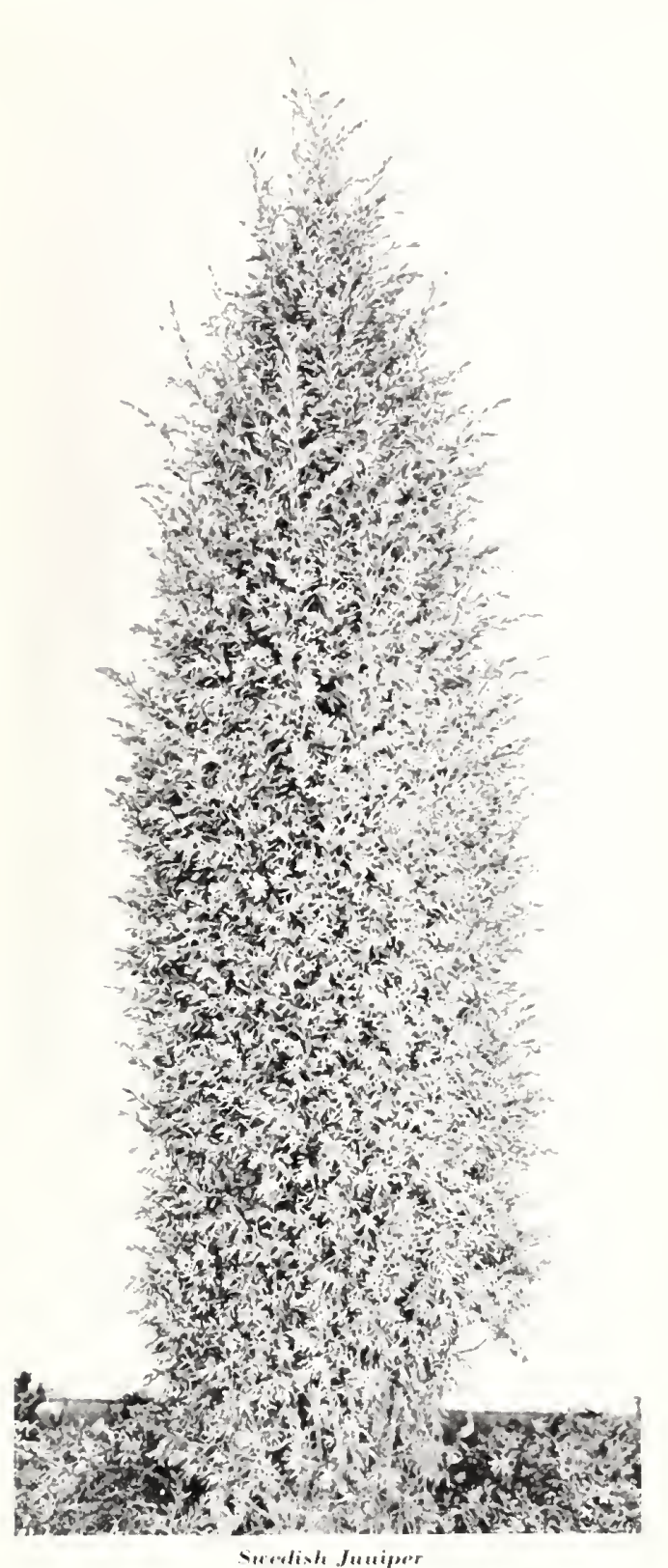

\section{Von Elaron Inuiper}

(Juniperus sabiun rou ehron)

$\mathrm{T}$

THS is an intereting variation of the
Sarin Jumiper. It is a rare varicty - compact and it has an irregular low sperendIng form. It is one of the fartext growing of all Junipers, having a most thrifty and robust constitution. The branthes grow in a semiirregular picturesque growth makes it well - nited for use in rock gardens and foundation planting.

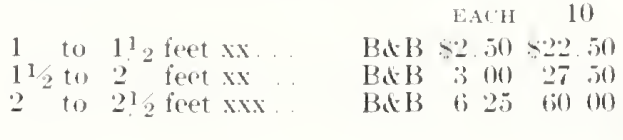

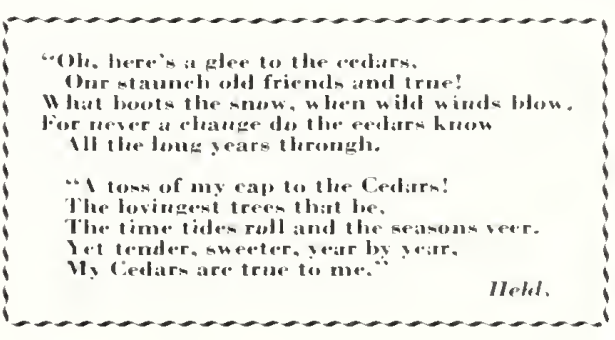

\section{Swedish .Imiper}

(Juniperus commmunis suerica)

$\mathrm{T}$ YHIs is the old favorite and familiar variety of extreme columnar form. It hut has the advantage of being more hardy than the Irish Juniper.

It grow very elose and compact. It reacher 10) to 12 feet in height with a diameter of only 12 to 18 inches when matured. It is a good tree for formal uxe and can be kept small by frequent trimming.

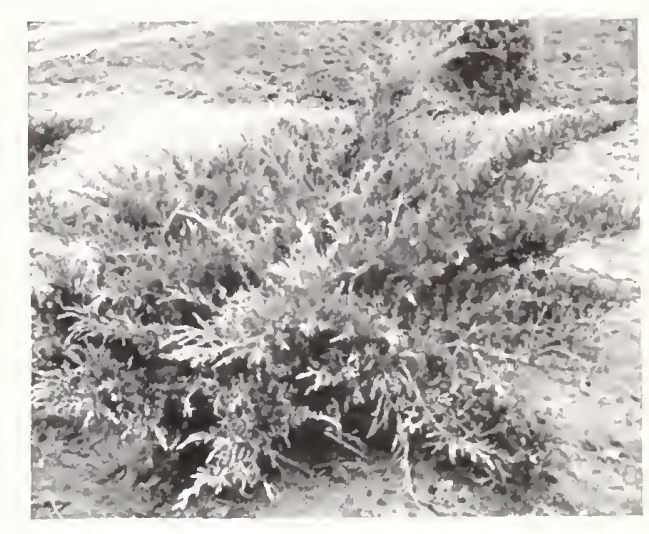

Houl Ehrou Juniper

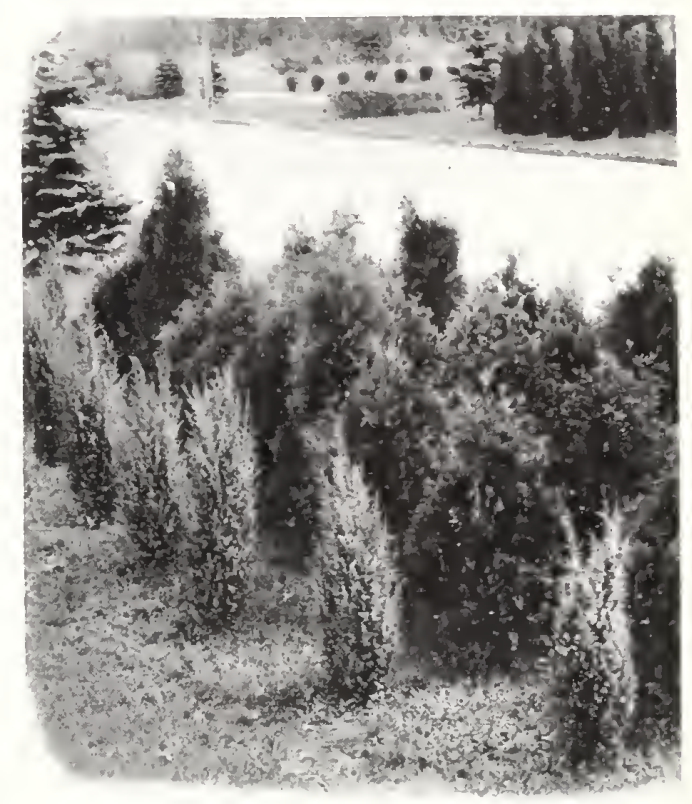

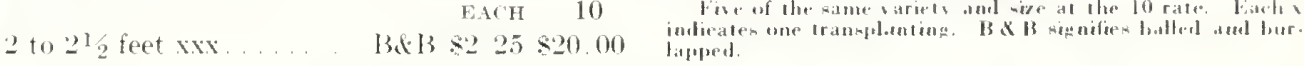

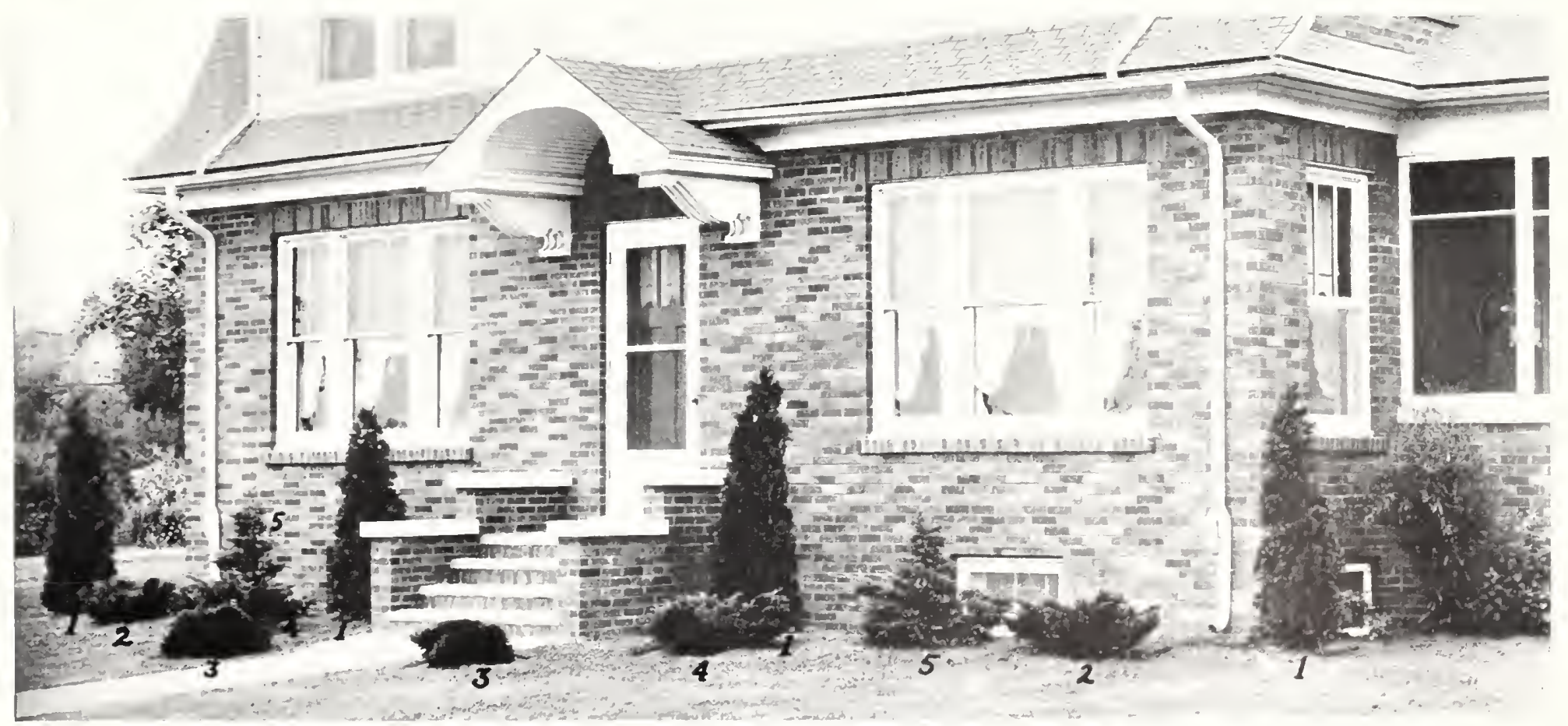

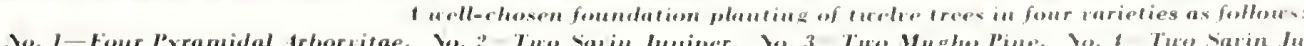




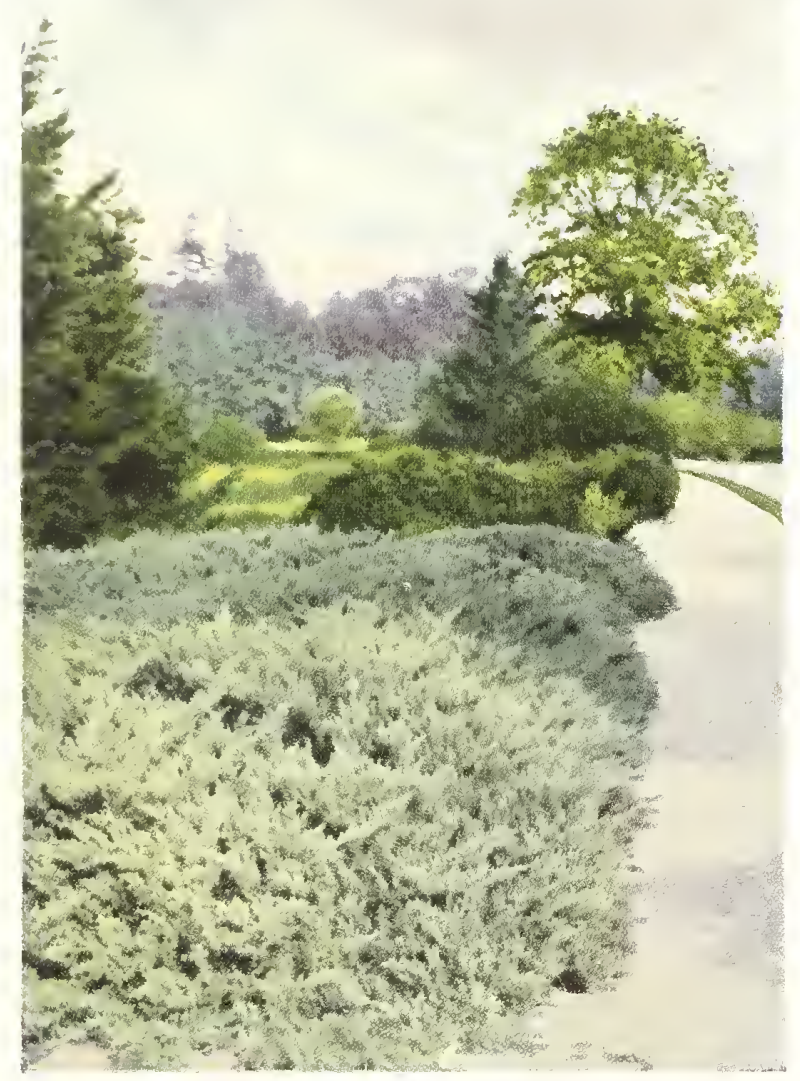

Sargent Juniper in the trnold Arboretum

\section{Salngent onuipeno}

(Juniperus surgenti)

$\mathrm{T}$ HIS is a sea-shore Juniper discovered by Sargent in northern Japan, about 1892. It forms a prostrate mat, 8 to 10 feet across when fully developed, like all dwarf Evergreens, may be kept smaller by trimming. It grows only a few inches in height.

In order to produce an effect as shown in the picture above, a number of trees must be grown together. In fact, practically all plantings of creeping Evergreens should have not less than thrce or four trees set quite close together so as to give a mat-like appearance. A distance of two to three feet apart is not too close.

This is a rare variety of distinct character, which will help to lift your Evergrcen planting out of the commonplace. It likes plenty of sun. Foliage is bright green, when first coming out, taking on a bluish cast as the season progresses. An extremcly hardy type which will do well in poor soil.

10 to 12 inch $\mathrm{xx}$

12 to 18 inch $x x$

15 by 15 inch $\mathrm{xxx}$ trmmed speimens.

18 by 18 inch $x x x$ trimmed specimens.

$\begin{array}{ccc} & \text { EACH } & 10 \\ \text { B\&B } & \$ 2.00 & \$ 17.50 \\ \text { B\&B } & 2.50 & 22.50 \\ \text { B\&B } & 5.25 & 50.00 \\ \text { B\&B } & 6.25 & 60.00\end{array}$

\section{IIIII Waukegian .Jumipere}

\section{Juniperus horizontalis douglasi}

PHIs is one of our own introductions to which - we have given especial attention for a number of years. Its unique point of merit is its color. It takes on a winter hue, as shown in the picture to the right. During the summer months, it is of a soft blue color.

Its foliage is composed almost entirely of the scalelike, or whipcord Juniper foliage. It is a contrast to the prickly, needle-shaped foliage of some of the other

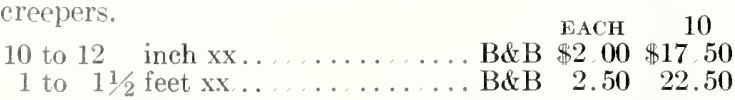

Five of the same variety and size at the 10 rate. Each $\mathrm{x}$ indicates ne traneplanting. B\&B signifes bulled and burlapped.

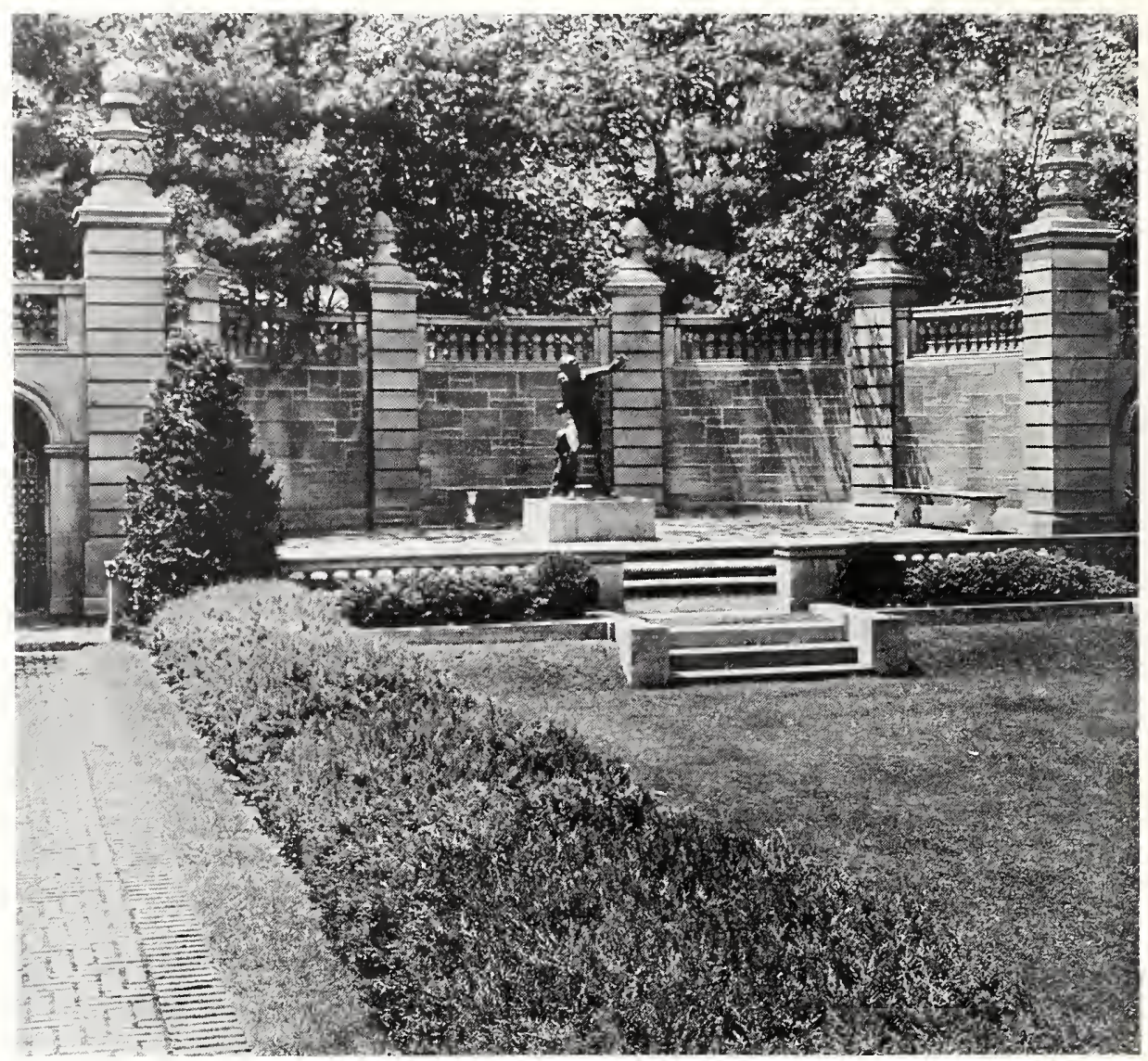

A novel low border planling of creeping Juniper

\section{The Use of Creeping Evergreens}

$\mathrm{P}$ OPULAR interest in creeping Evergreens is growing every day. As they become better known, new uses are continually being found. No extensive country estate provide a home for a planting of creeping Evergreens.

The pictures on pages 22 to 25 offer suggestions for their use. As a border to taller Evergreens, they add a finished appcarance as shown in the picture above.

For covering a bank or terrace, they provide a beautiful carpet of grcen or blue foliage throughout the year.

In a rock garden or around a pool, creeping Evergreens find their greatest usefulness in landscaping. They cling to and overhang the rocks in the most graceful manner.

Therc is a wide choice in shades of color, including hues of green, blue and plum color In texture of foliage, there is plenty of variation to suit every need.

When used as a ground cover, always plant in groups of several trecs, allowing 2 to 3 fect between plants. In this way a solid mat will soon develop which will completely cover the ground. While all are strictly dwarf in habit, an occasional trimming will serve to keep them within bounds for years.

In Japan where the fine art of landscaping small areas has been most highly developed, dwarf Evergreens have always been important objects in the landscape.

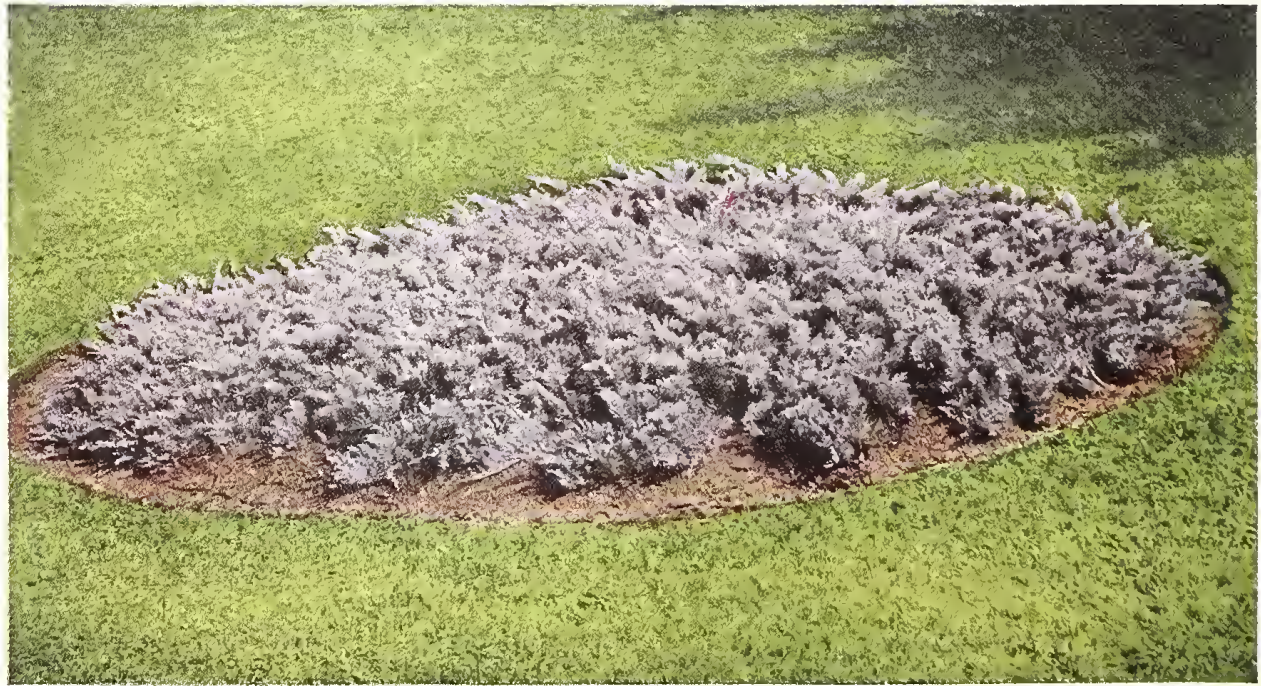

A hillside planting of Waukegan Juniper 
aritent

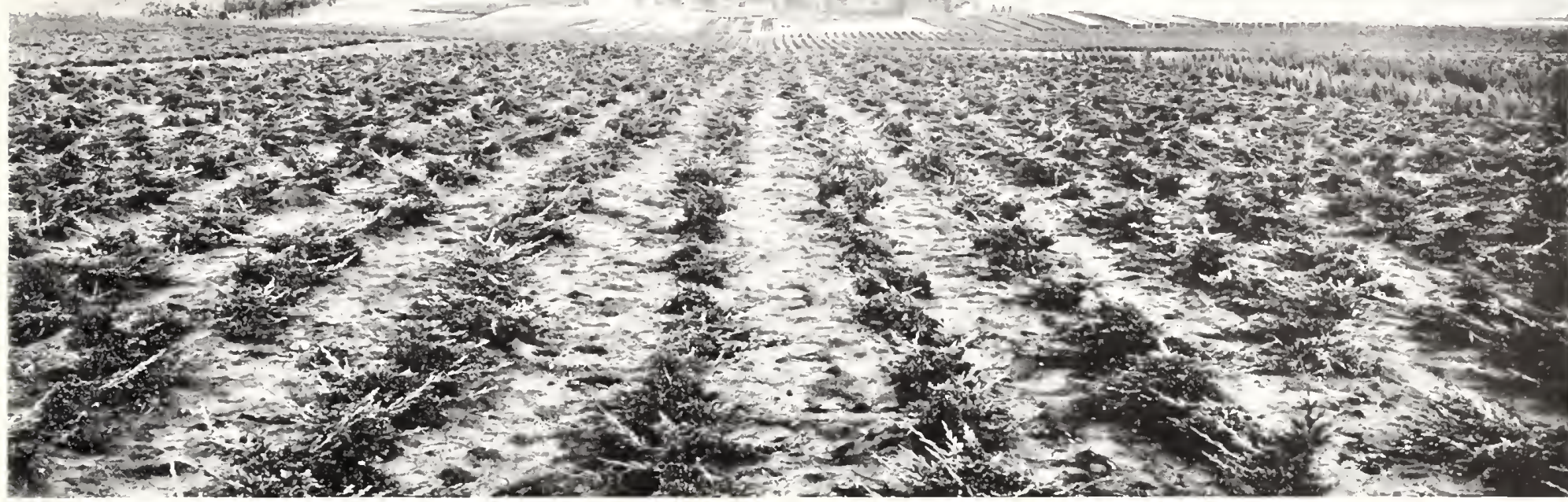

In the mursery row, Jananese Juniper moke iuterosting sub-

\section{- Japanese . Inmiper}

(Jtriperts japortica)

\section{Juriperts chimensis proctublum.}

HE following description is taken from a bulle-
tin of the Annold Arboretum, Harvard C niver-
sity: "This is the best known of the prostrate Junipers which Japan has sent the gardens of America It is a plant with wide sprealing creeping stems, bluegreen. It has tharply pointed leaves marked on the upper

Tery old plants will reach 6 or $\rightarrow$ feet in diameter we a helght of only to l2 inches. Howerel, it ma making it an ideal subiect for hanging over rocks for terraces and low beds of varioum kinds. It is exceptionally robust, and a strong lugged grower. It thrives in full sun and is one of the few Junipers that will also stand considerable shade.

There is considerable variance among varieties

by grafting, only from the true strain of hardy compact growing plants we importesl direct from Japan the benefit of our long experience in growing " true to

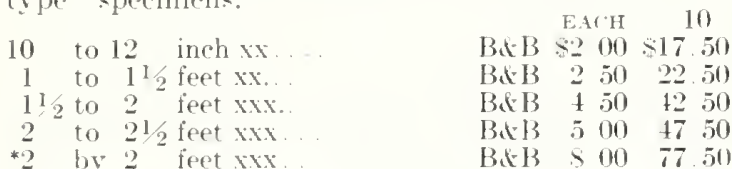
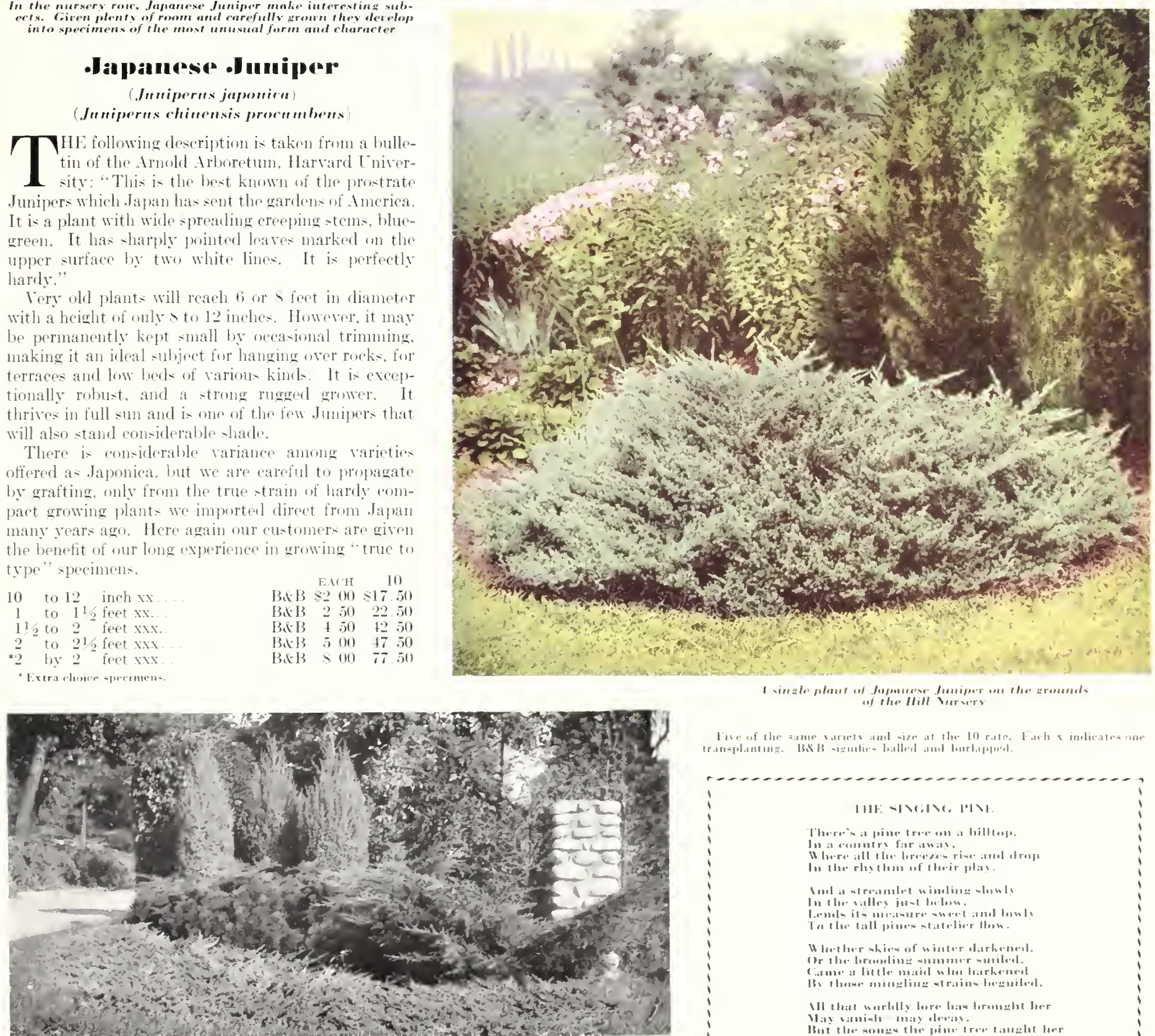


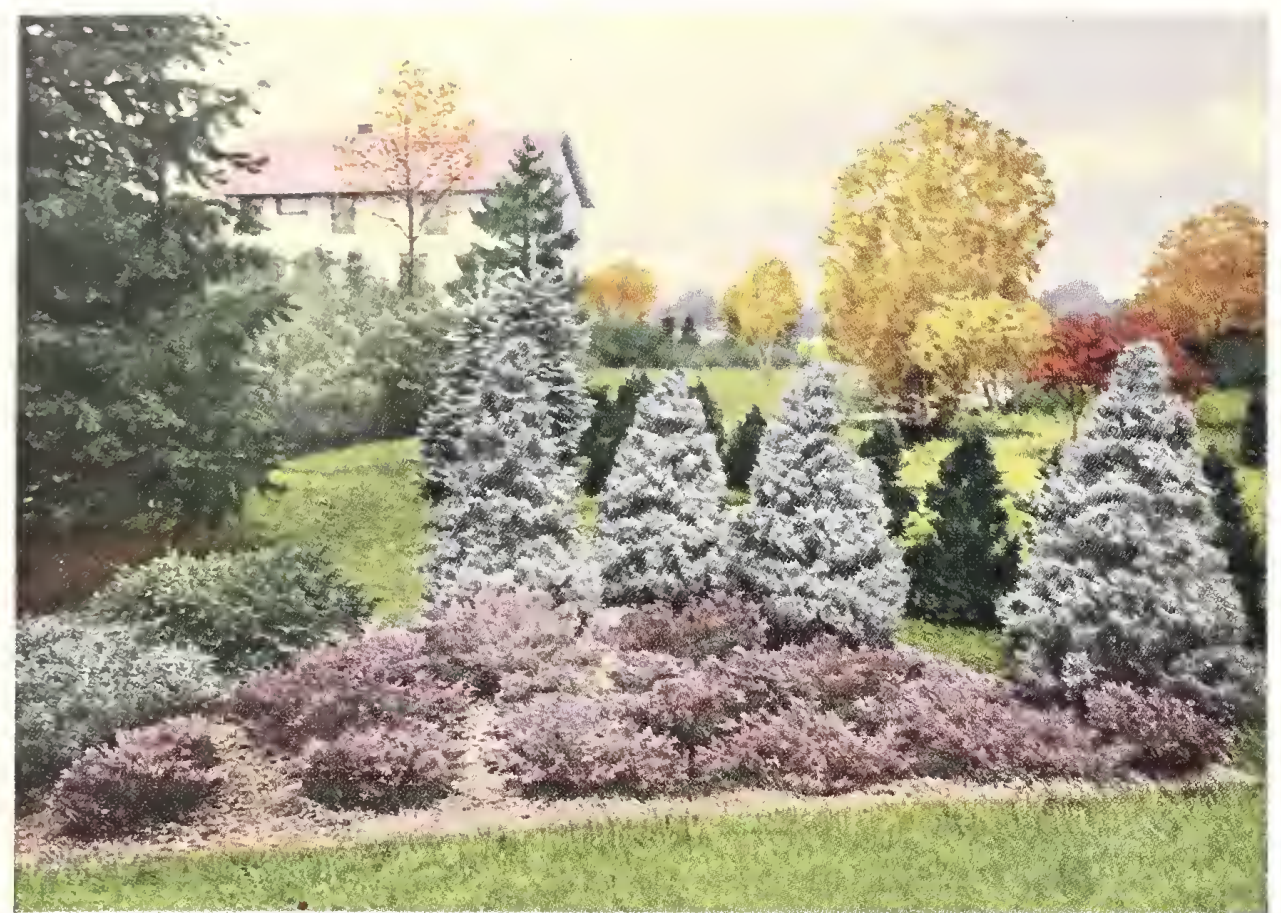

The contrasting color of the Indorra Juniper against a bachground of Stler Redcedar brings out the

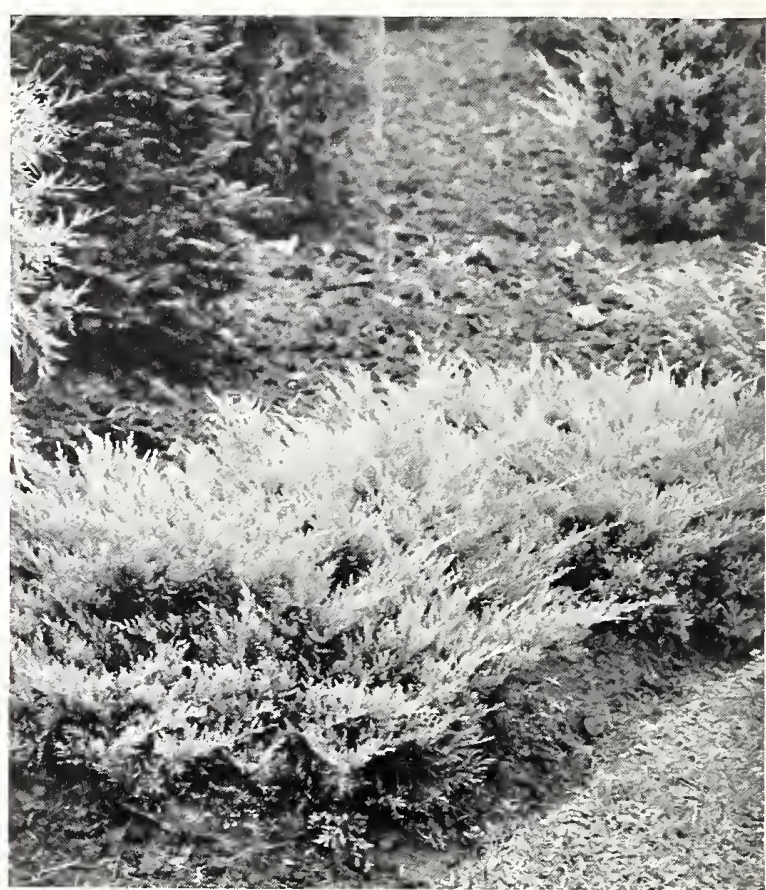

The summer color is silter grayish green, which changes with the first frosts of Autumn

\section{Andorra Inniper}

(Juniperus communis depressa plumosa)

$\mathrm{A}$ TE IV low-growing, spreading dwarf Evergreen of most distinctive color and graceful form - a beautiful silvery green in the Spring, turning to a silvery purple or pinkish shade in the Autumn, as shown in our colored picture, giving a combination of coloring not found in any other tree of this type.

It does not cling so closely to the ground as some of the other creeping forms. It lifts its branches about 15 to 18 inches off the ground and for this reason fills a somewhat different need in landscaping.

Under favorable growing conditions in a sunny place, it may reach a spread of 5 or 6 feet. However, it is easily trimmed and can be kept within bounds. In fact the trees shown in the colored picture, which are growing on our nursery grounds, have been kept at practically the same size for nearly ten years.

It is very useful to fill in at the base of taller growing Evergreens, good for foundation groups, for terraces and for rock gardens. It is of particular interest in this way on account of its charming and unusual color.
While it is said to have been originally found in a lot of Prostrate Juniper (Juniperus communis depressa) seedlings, it has none of the characteristics of this latter variety.

It is a comparatively rapid grower, which does best in a sunny or partially sunny location. It will grow in shade but the growth is slower and less vigorous. Andorra Junper is a very hardy sort that needs no favoring in winter.

We have offered this tree for only the past five years, but it is already one of the most popular varieties.

\section{0 to 12 inch $\mathrm{xx}$}

1 to $11 / 2$ feet $\mathrm{xx}$

1 to $1 \frac{1}{2}$ feet $\mathrm{xxx}$

$11 / 2$ to 2 feet $\mathrm{xxx}$
EACH 10

$\mathrm{B} \& \mathrm{~B} \$ 2,00 \$ 17,50$

B\&B $300 \quad 27.50$

$\begin{array}{lll}\mathrm{B} \& \mathrm{~B} & 3.75 & 35.00\end{array}$

$\mathrm{B} \& \mathrm{~B} \quad 4.50 \quad 42.50$

Five of the same variety and size at the 10 rate. Each $x$ indicates one transplanting. B\&B signifies balled and burlapped.

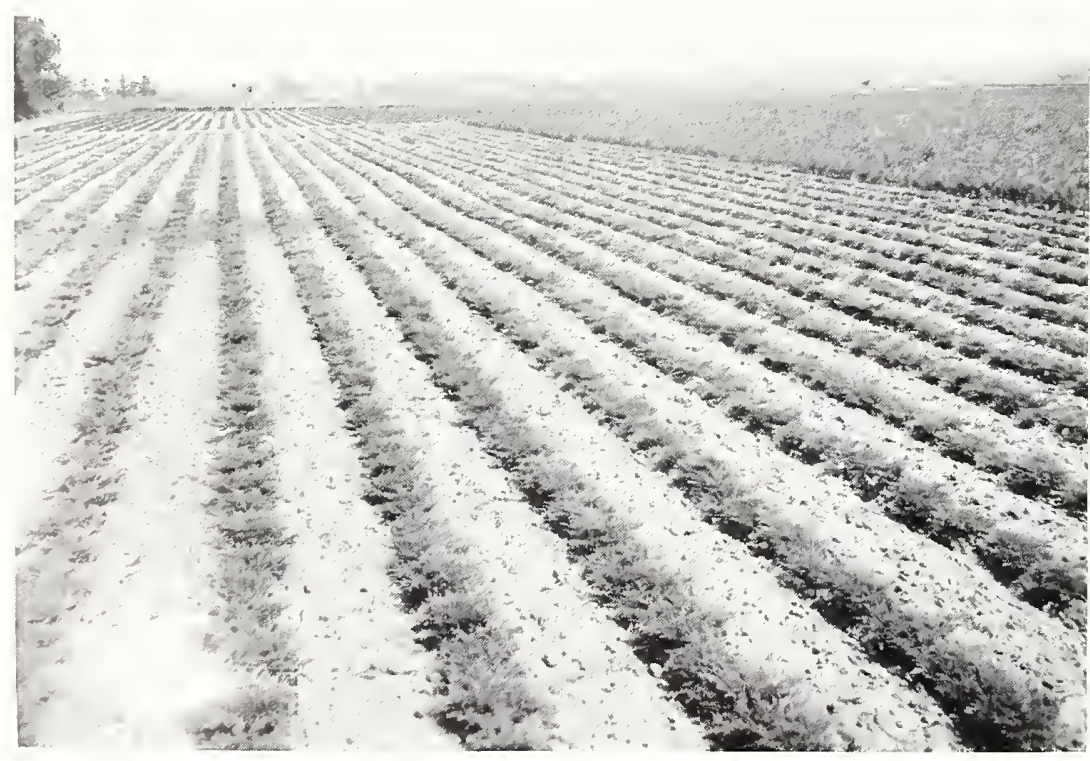

Thousands of Andorra Junipers are groun by Etergreen specialists under ideal conditions in the lill Nursery. Several sizes to choose from

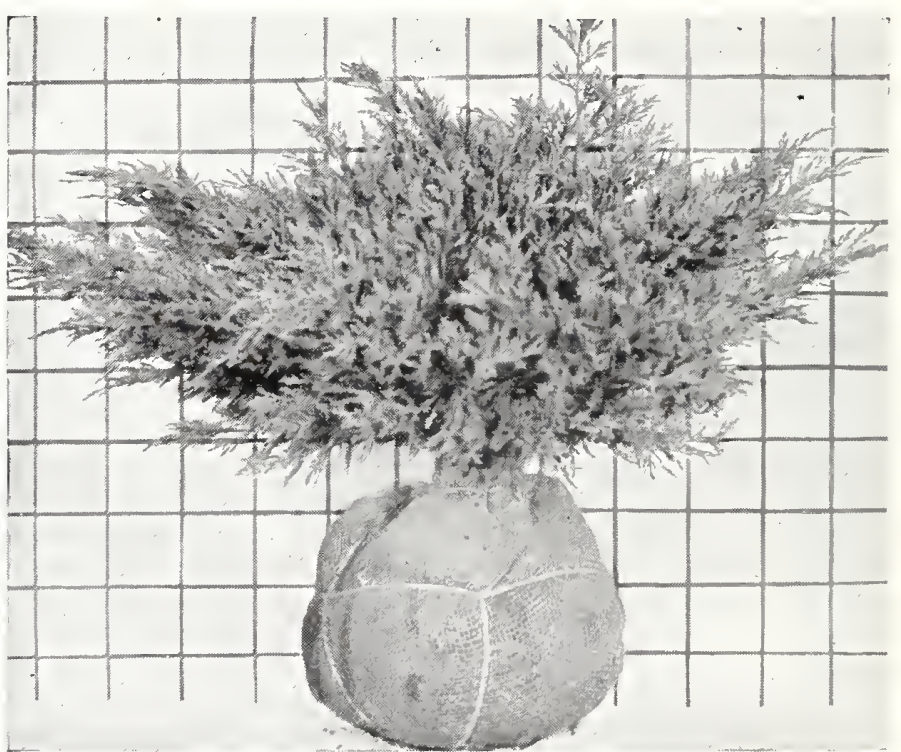

This actual photograph of a 1 o $11 / 2$ feet $x \times B \& 13$ spectmen shotes the thifiy development of the stoch offered. The squares shoun in bachground of pic- 

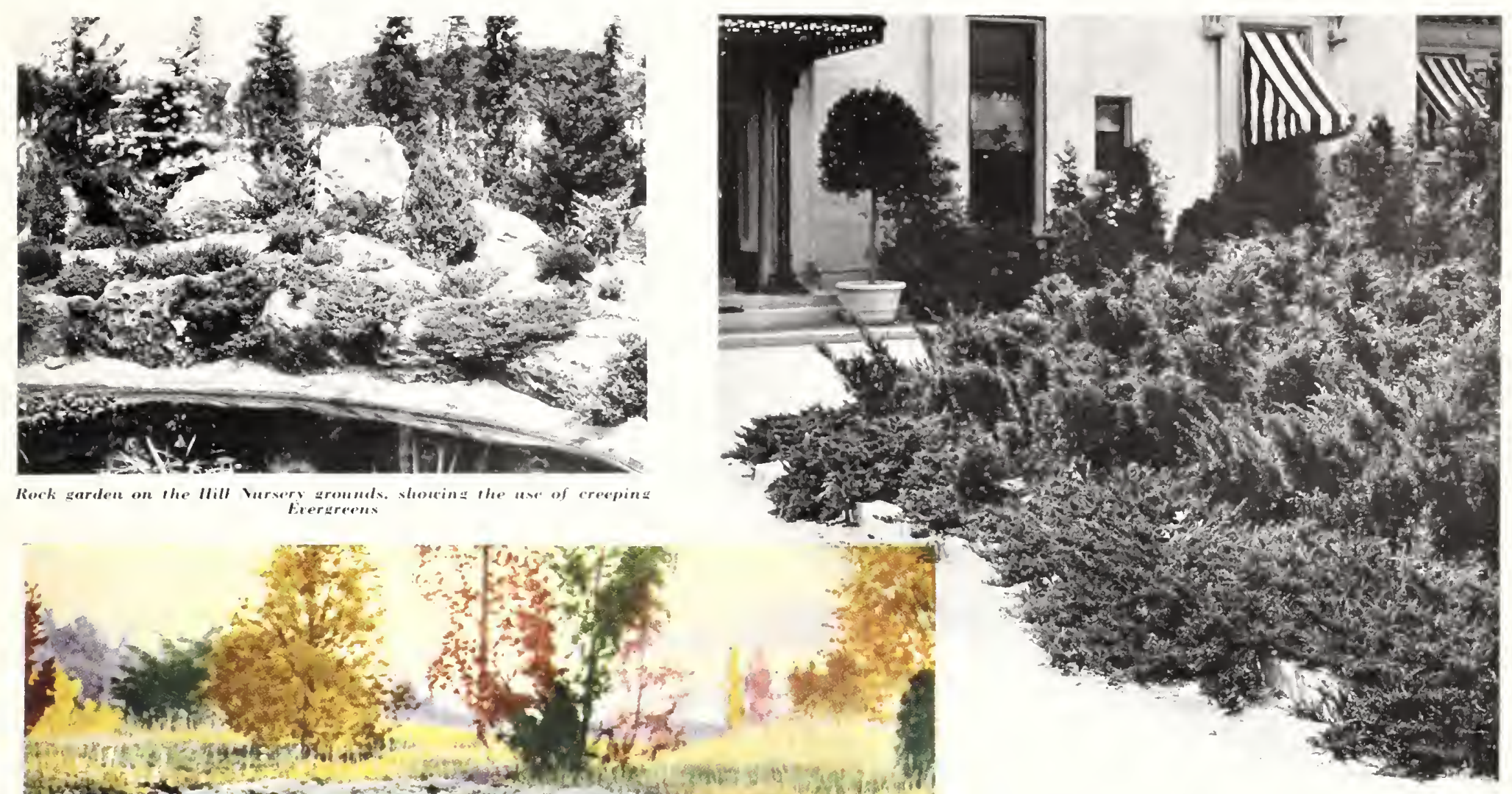

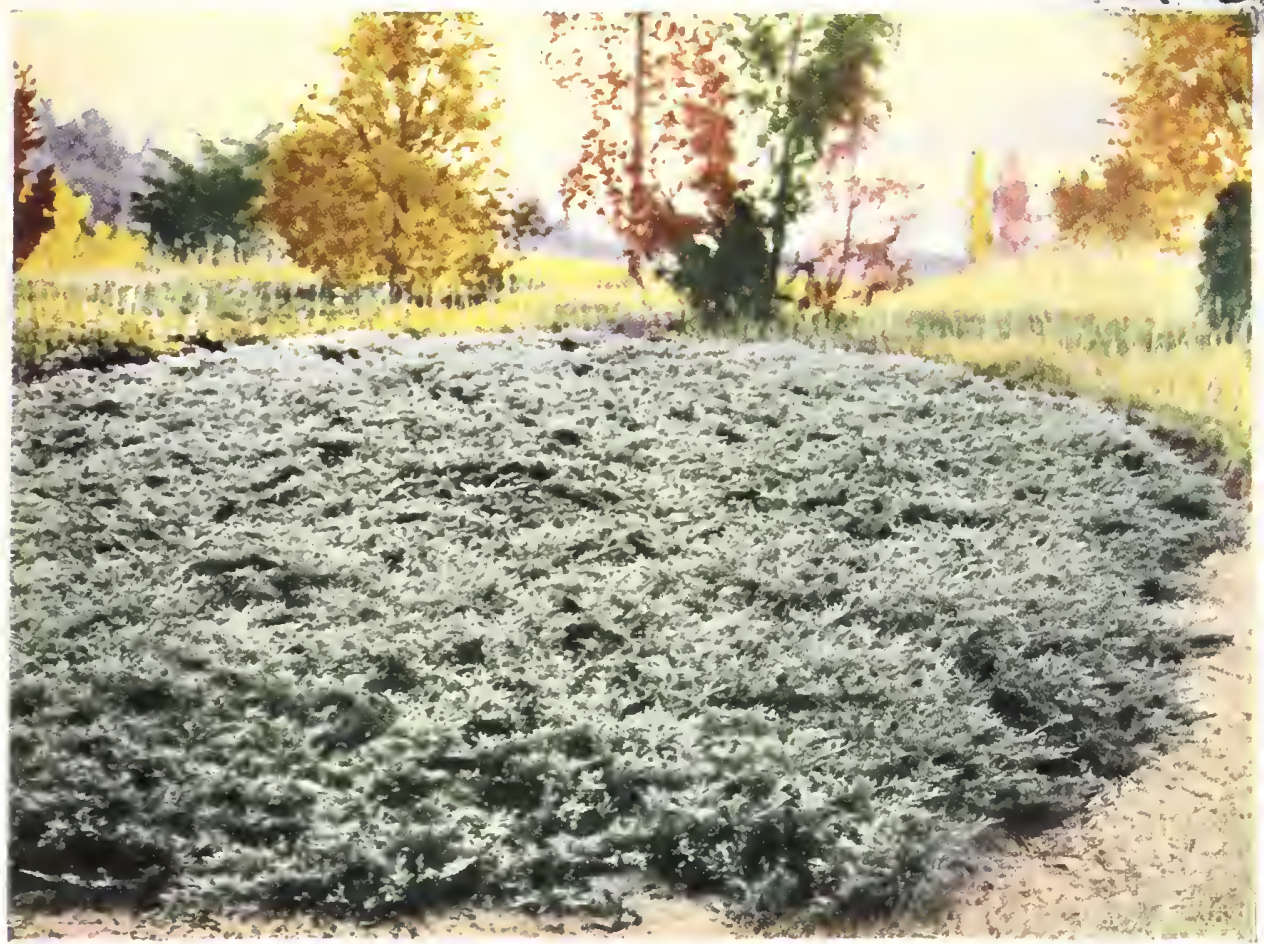

Bur llarbor Juniper at the Irrold Arberetum, Bowton. Massaclunett

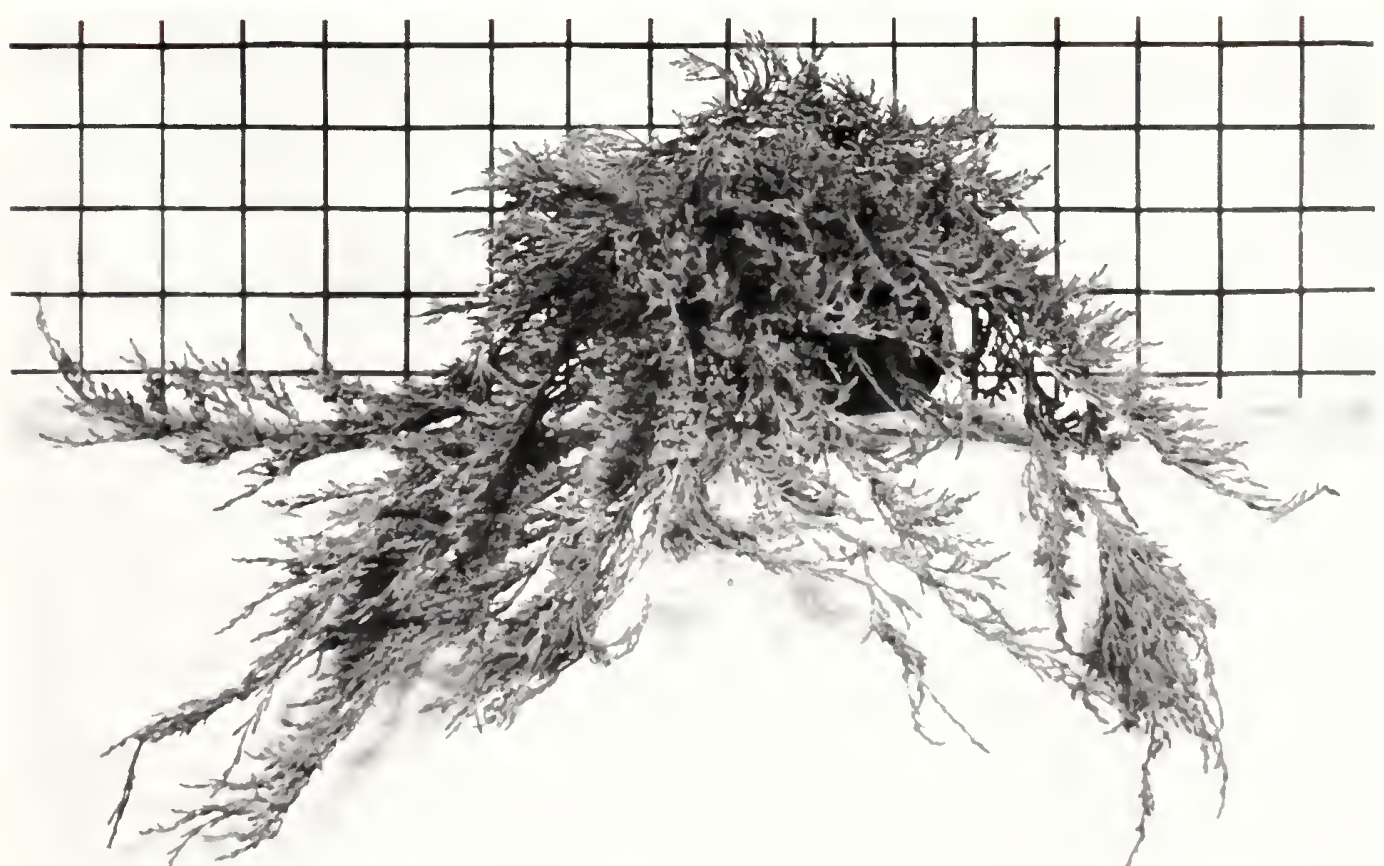

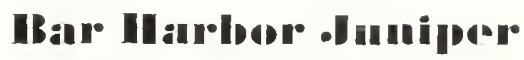

(Juniperus subiun luorizouldelis)

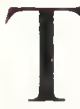

CHE colored pieture is a photoglaphla takelu at the Arnold Arloretum, showing a style of planting
which is ardom reen exeept in extensive grounds. This picture illustrates the eolor of the tree and general habit. It is, of eonrse, alio aclapted to mall areas, for use on terraces or in rockeries and in -imilar situations. As the name inclicates, the native the vieinity of Bar Harlor. Conturies of exposure to the roek-bound and wind-kwept coant of Mame make this tree unusually rugged.

It has sturdiness, hartiness and the most beautiful greenish bluc eolor, as if it held for its own the reflection of the orean wares. This
tree brought to your garden will bring with it some of the lure of it native home. A true
crecere, resting close to the ground. American planters are indebed to the Arnokl Arboretum for the introluction of thi- vitriety:
EACH 10 Five of the same barim, and size at the 10 rate. Each hirlapived. 


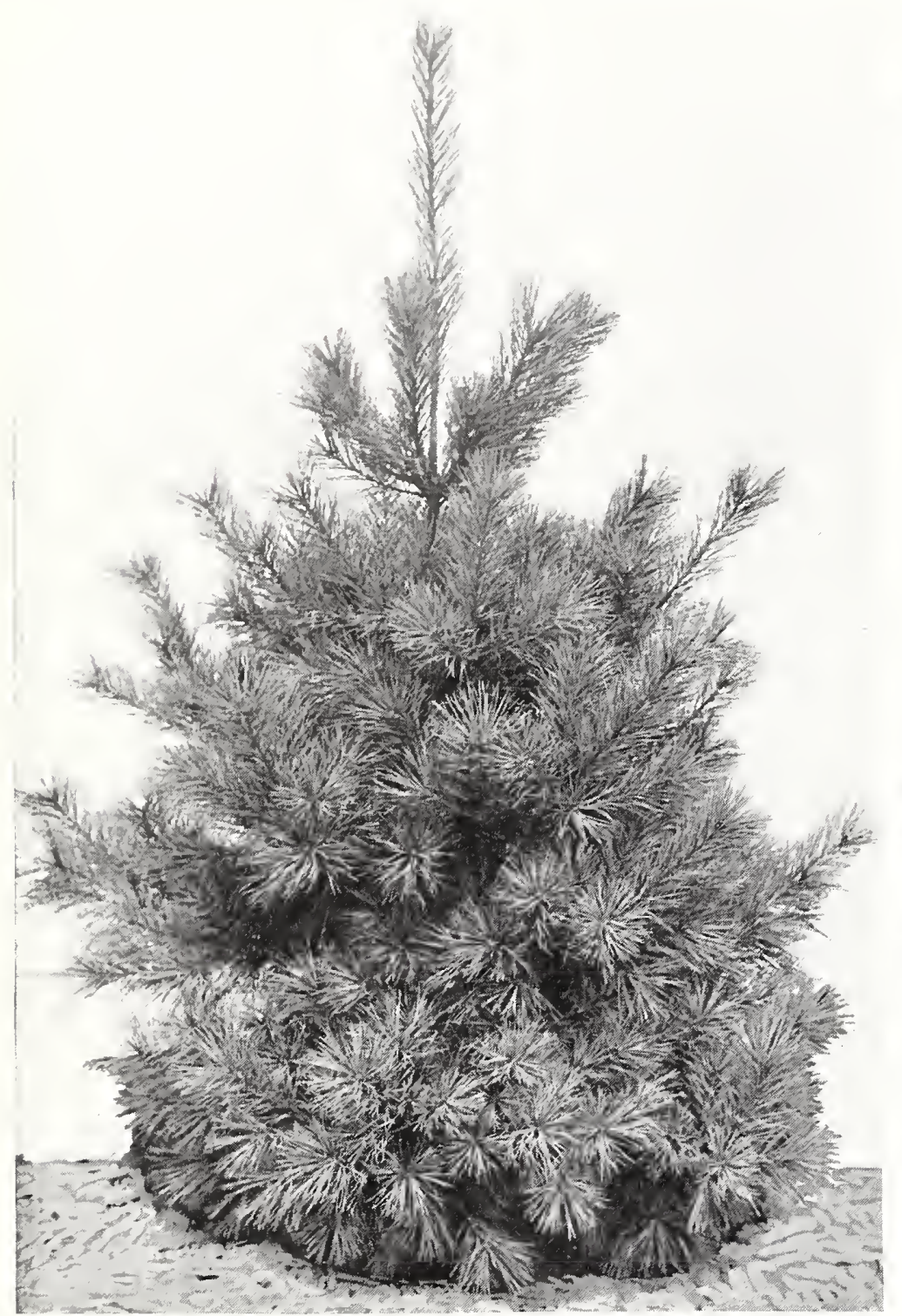

\section{White Pine}

(Pinus strobus)

HITE PINE has long been of great commercial value for tim-
ber It formerly grew abundantly throughout the northern
Lake states, where it is the largest of all native Evergreens. It grows very fast, Its needles are 3 to 4 inches long, soft, flexible and, unlike most other varieties, there are five needles in each little bundle or sheath It is able to grow well on both dry and moist soil and on rich or poorest soil. It will also endure some shade for a number of years.

White Pine is a beautiful object planted alone, its horizontal branches shightly curving upward. It will also bear considerable crowding which makes it adapted for use in close growing screens, backgrounds or windbreaks.

$1 / 2$ to 2 feet $x x$
2 to 3 feet $x x x$
3 to 4 feet $x x x$

Five of the same variety and in signifies balled and burlapped.

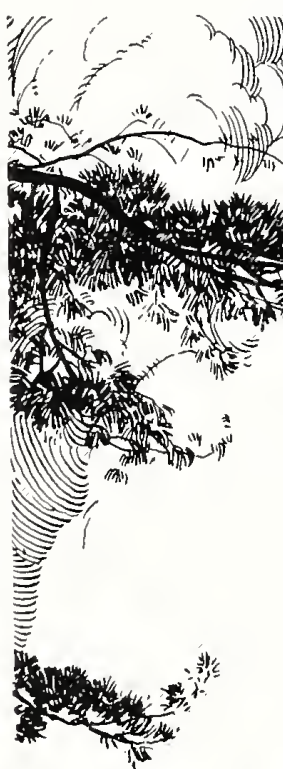

$\mathrm{EACH} \quad 10$

B\&B $\$ 2.00 \$ 17.50$

B\&B $2.50 \quad 24.00$

B\&B $\quad 300 \quad 29.00$

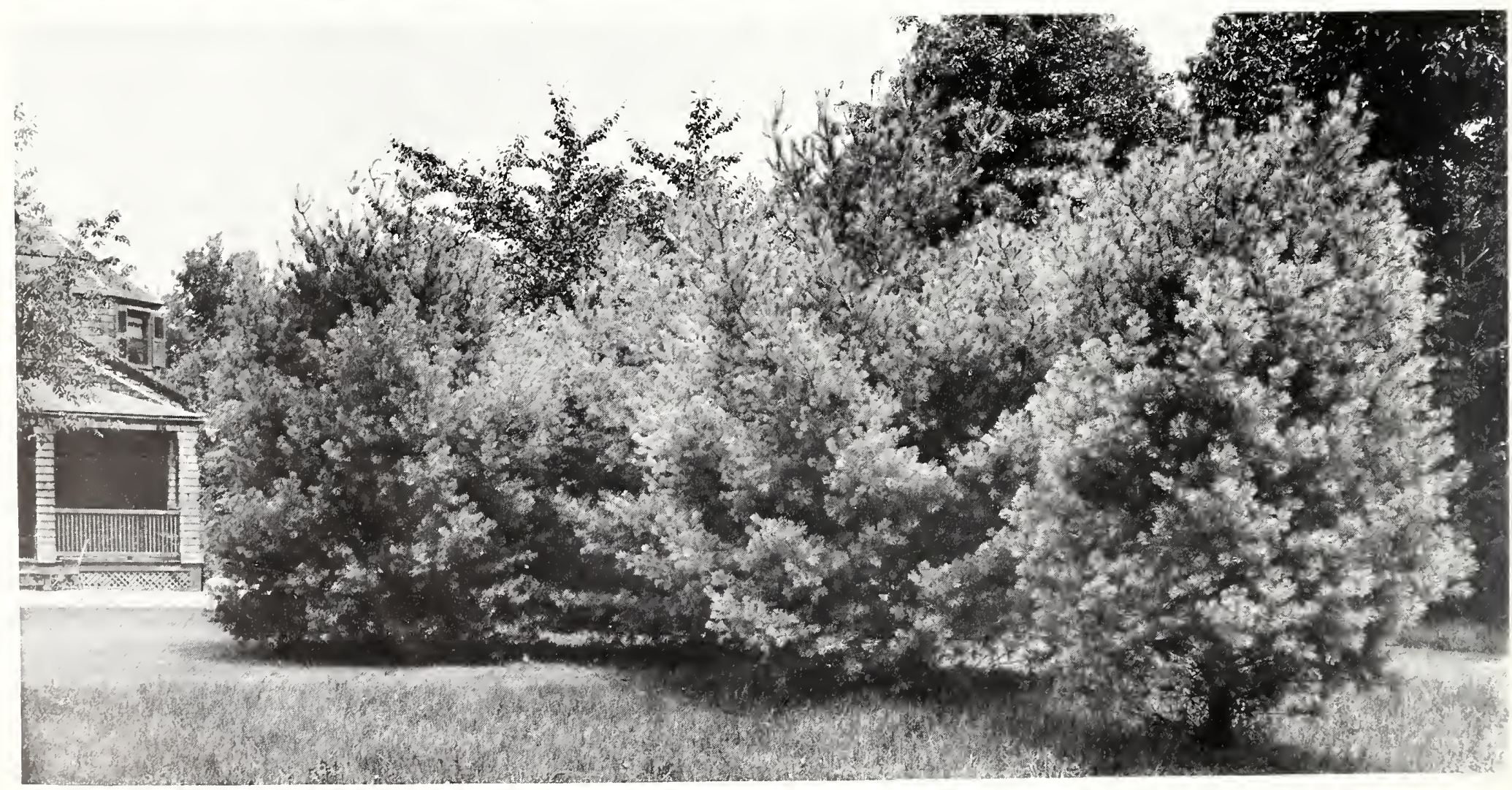

No refran

What is the secret the pine trees hnow,

That keeps them whispering soft and low? All day long in the breezes swaying,

What can it he they are always saying? -Jennie G Clarke.

But the trees all kept their

Only there sighed from the pine tops
A music of seas far away. The fraorant pines, no choir's swelling voice

Of roaring surf, or distant thunder's noise,

Heard in the forest evergreen-while long And loud in primal tones they do rejoice. -Leslie Burroughs. 


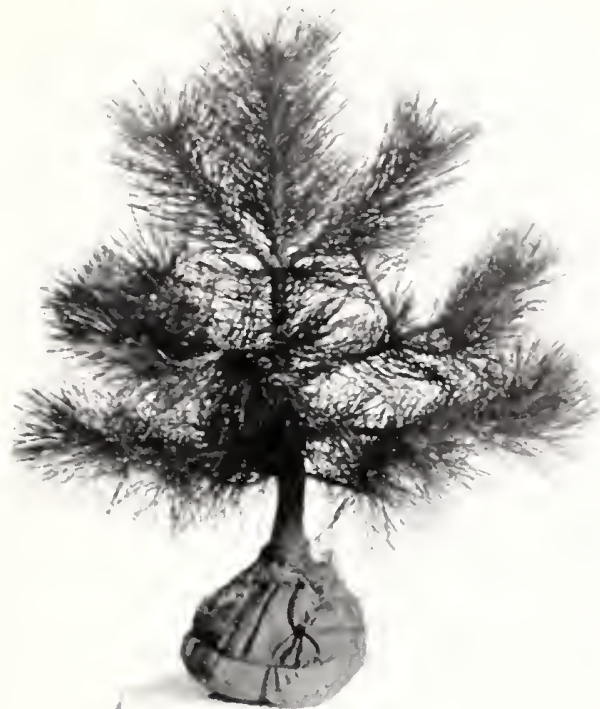

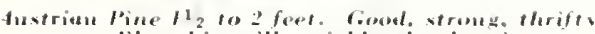
sizable trees

\section{Austrialn Pine}

lintus migra

\begin{abstract}
legal aud stately hehold it st and
lbove it brethen, towering grant,

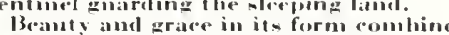

A moviarclo. Dewre of al noble line.

fomg mas it be ere its rase dlecline:

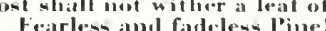

Varv F, Tuelier.
\end{abstract}

$\mathrm{F}$

Ell trees -how such remarkable resistance to the trying conditions of city planting. Coal, its growthe. It is a tree erpulaty sativfartory for shore planting or inlanel. It is by far the most popular and largest selling of the upright Pines.

Austrian Pine has such a deep rich green colol that it is known in some palts of Europe as the Black Pine. The needles are two in a sheath, straight and sender and four to five inches long.

In old trees planted in the open, the branch spread often nearly efual the height, but in the native forests of Eurole it reaches a great height. Inder farorable conditions the annual growth is one to two feet.

The growth is rlose and compact compared to mont other Pine. This fact and its fine color at all seasons, no doubt account for the great favor shown this tree by planters everywhere.

It has been planted in America for over 100 years and has proved itself well cleserving of a place in American landicapes.
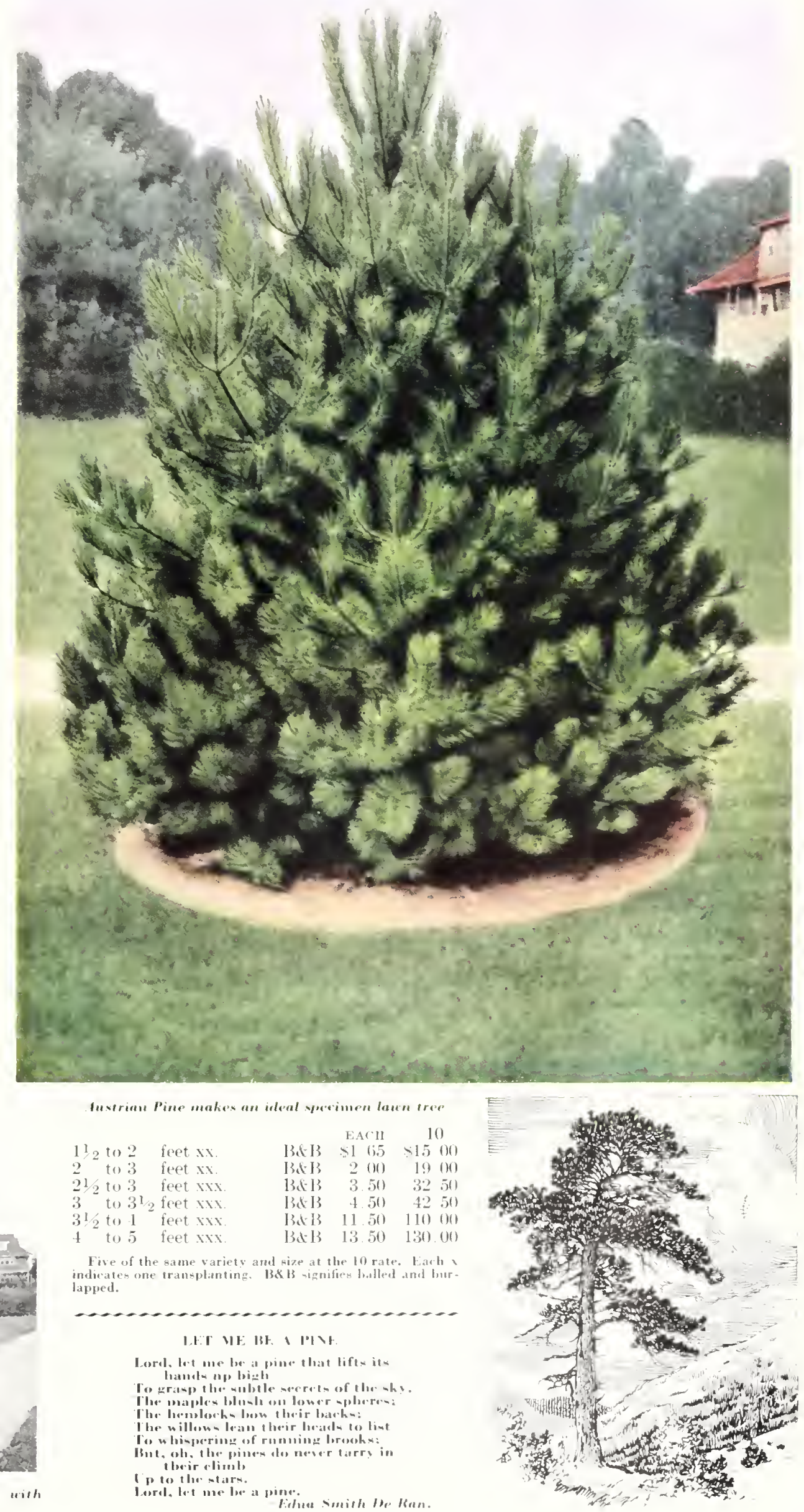

Five of the same variety and rize at the 10 rate. Lach indicate
lapped.

L.T. VE HE. I IOIY

Lord, lot me be a pine that lifte it

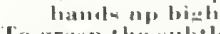

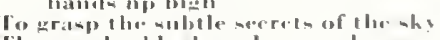

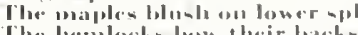

The lanblork- low therir barkes

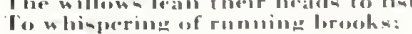

Ime, oh, the pin

ID to thestiors

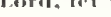

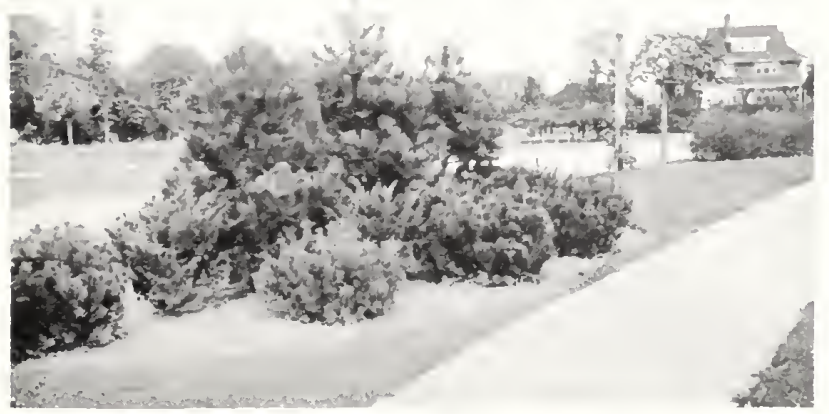

In this Parhay group the taller Austrinn Pine a 


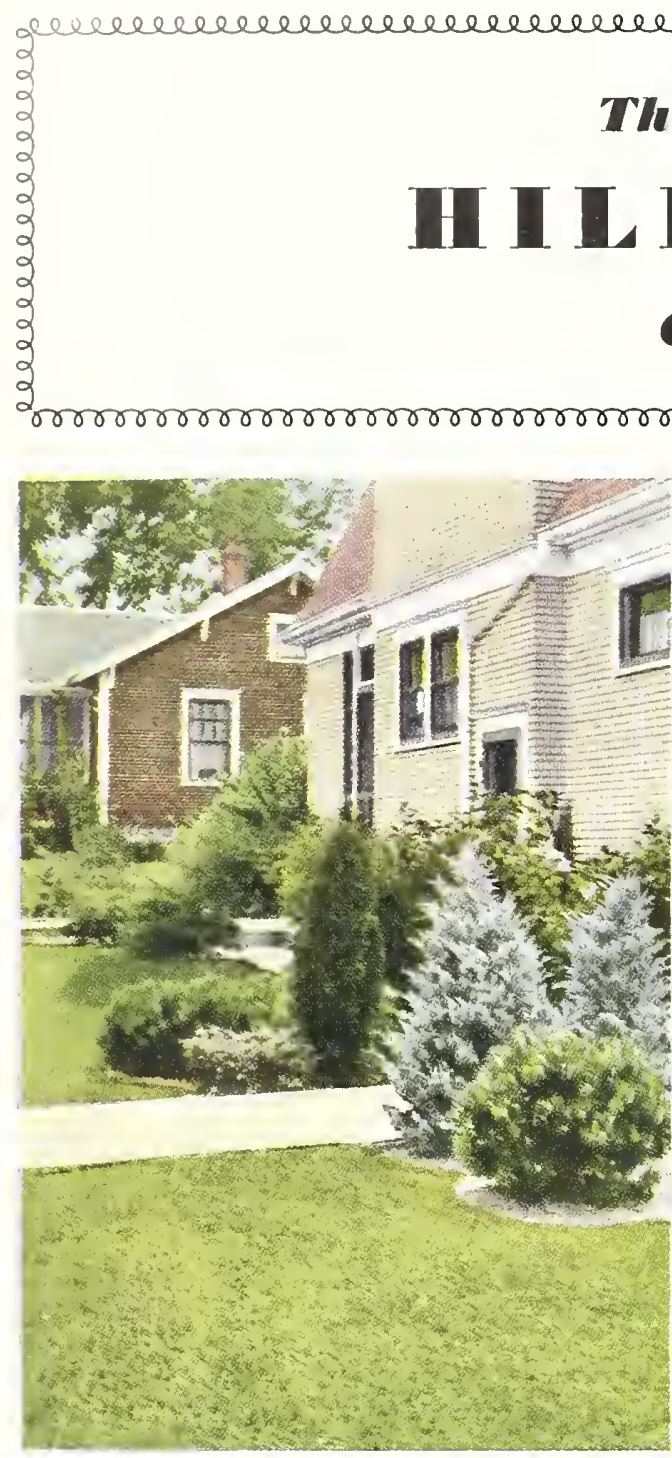
At entrances with groups of other Etergreens, Mugho
Píne is just ihe tree to use
$\mathrm{H}$

ILL MUGHO PINE is grown from a selected strain of seed which produces the true, many-stemmed, low-branched, dwarf type. In a very limited locality in the mountains of central Europe the seed of this true type is gathered. It is a mountain plant which grows high up on the mountain sides.

It does not have one main stem or trunk, but numerous stems which branch out close to the ground, spreading horizontally and then turning upward in even, regular growth.

The color is deep green in summer and winter. It is free from insects or pests of any kind, and will grow in almost any location.

It seldom grows over 4 to 5 feet tall, but spreads out 6,8 or more feet in diameter when full grown. By annual shearing it can be kept as small as desired; in fact, the trees shown in the bed planting on next page were kept for several years at a height of not more than 8 inches and 3 feet in diameter.

The old definition "Short and stout and roundabout" fits the Hill Mugho Pine. The growth is dense and the plants are thickly covered with heavy, dark green needles. The various pictures on these pages will give a good idea of some of the various uses

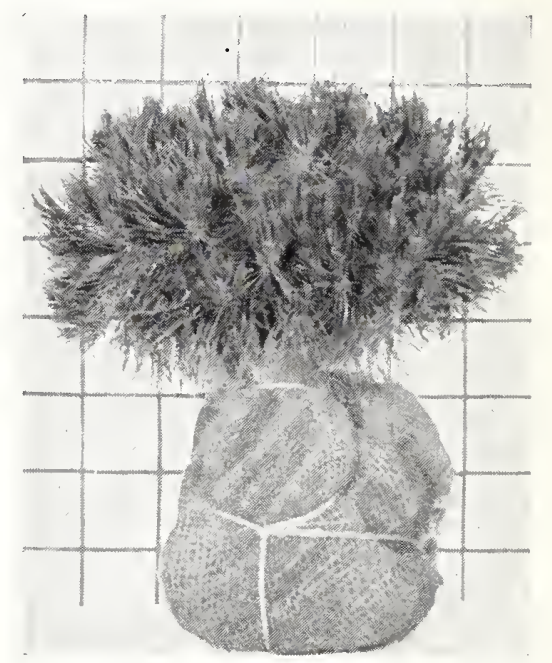

By producing Mugho Pine in immense quantities, ard transplanting frequently, Hill Mugho Pine are all selected for type, only the true dicarf compact trees are used. This is a picture of the 10 to 12 inch $x . x$ grade. Eien in the small size, these trees have all the characteristics of old trees

THE OLO TKEE SPEAKS

Feet grounded in Earth's titan heart,

$M y$ head wreathed in God's sky,

I see man come, pause, and depart, As centuries sweep by.

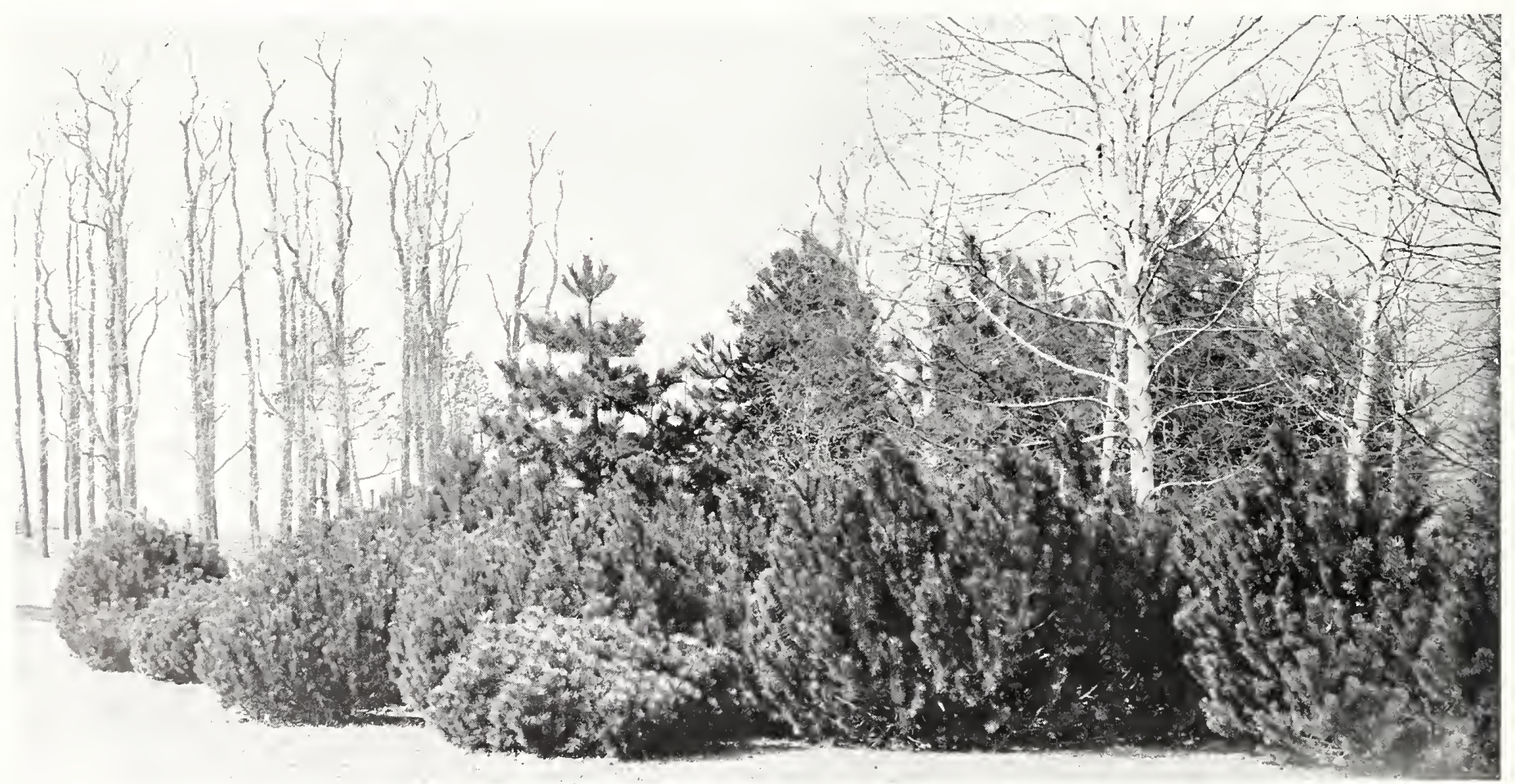




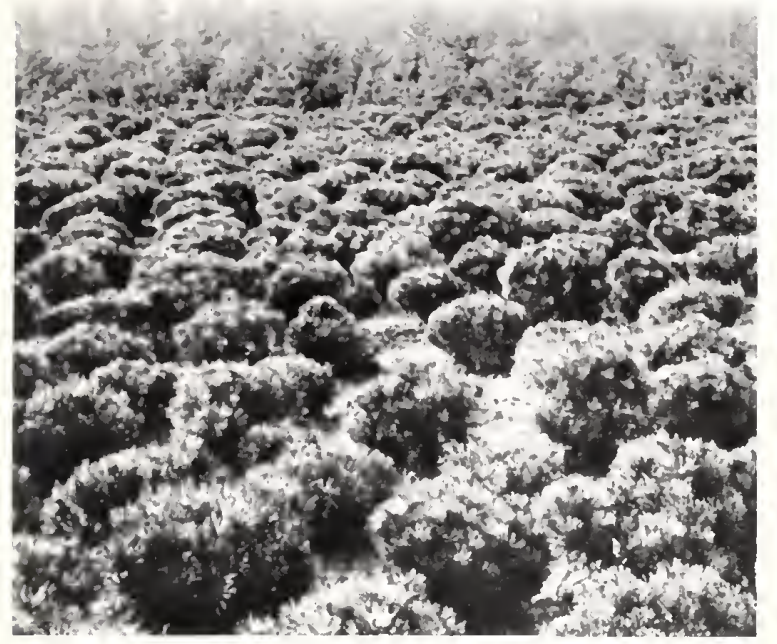

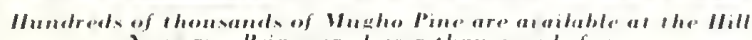

to which this tree may be put and the different habitit assumes under various planting conditions.

Hill Mugho Pine is a tree which is fairly tolerant of shade and it will grow on the north side or the sharly side of a building quite -urees-rfully. It is without question the outstanding dwarf Evergreen tree for allround uses.

\begin{tabular}{|c|c|c|}
\hline 10 to 12 inch $x x$. & 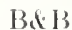 & $\rightarrow 1.5$ \\
\hline 12 by 12 inch $x \times x$ & Bdis & 20 \\
\hline 15 by 15 inch xxx. & Bdis & 25 \\
\hline is by is inch xxx. & Bitis 13 & 3.5 \\
\hline 24 by 24 inch $x x x$ & BiE 13 & 5.2 \\
\hline
\end{tabular}

Five of the same variets and eize at die 10 rate. Each $x$ indicate

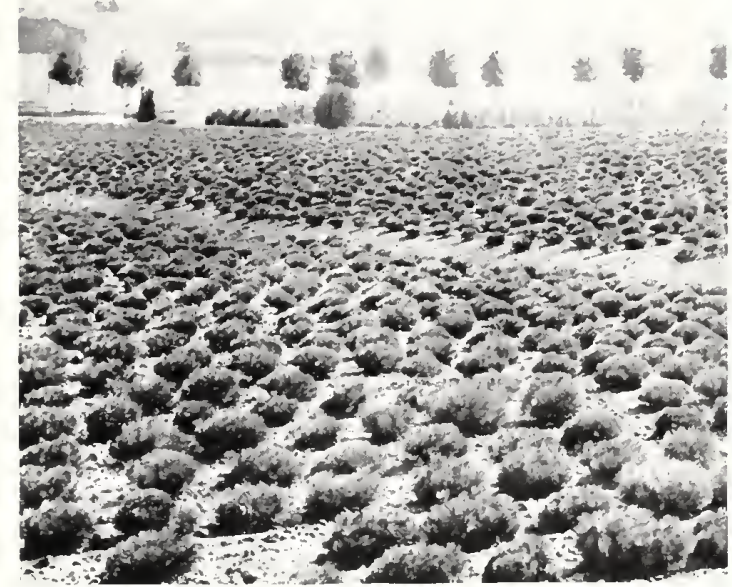

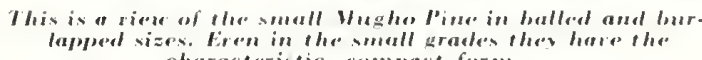

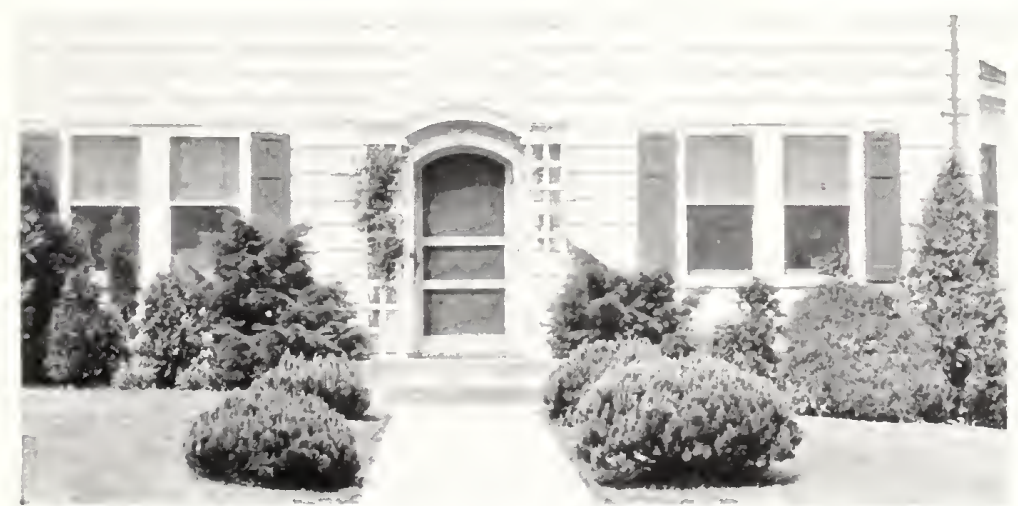

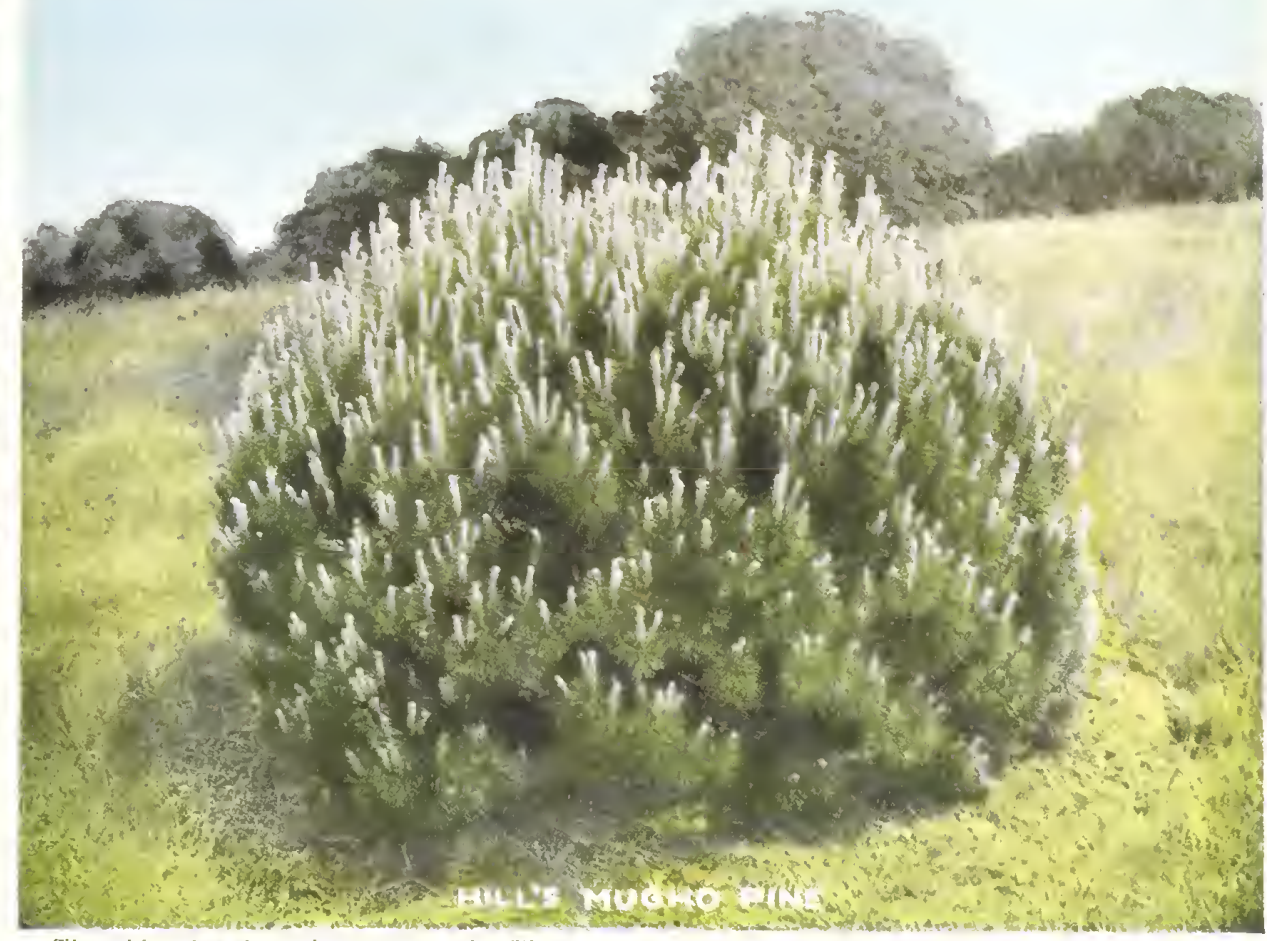
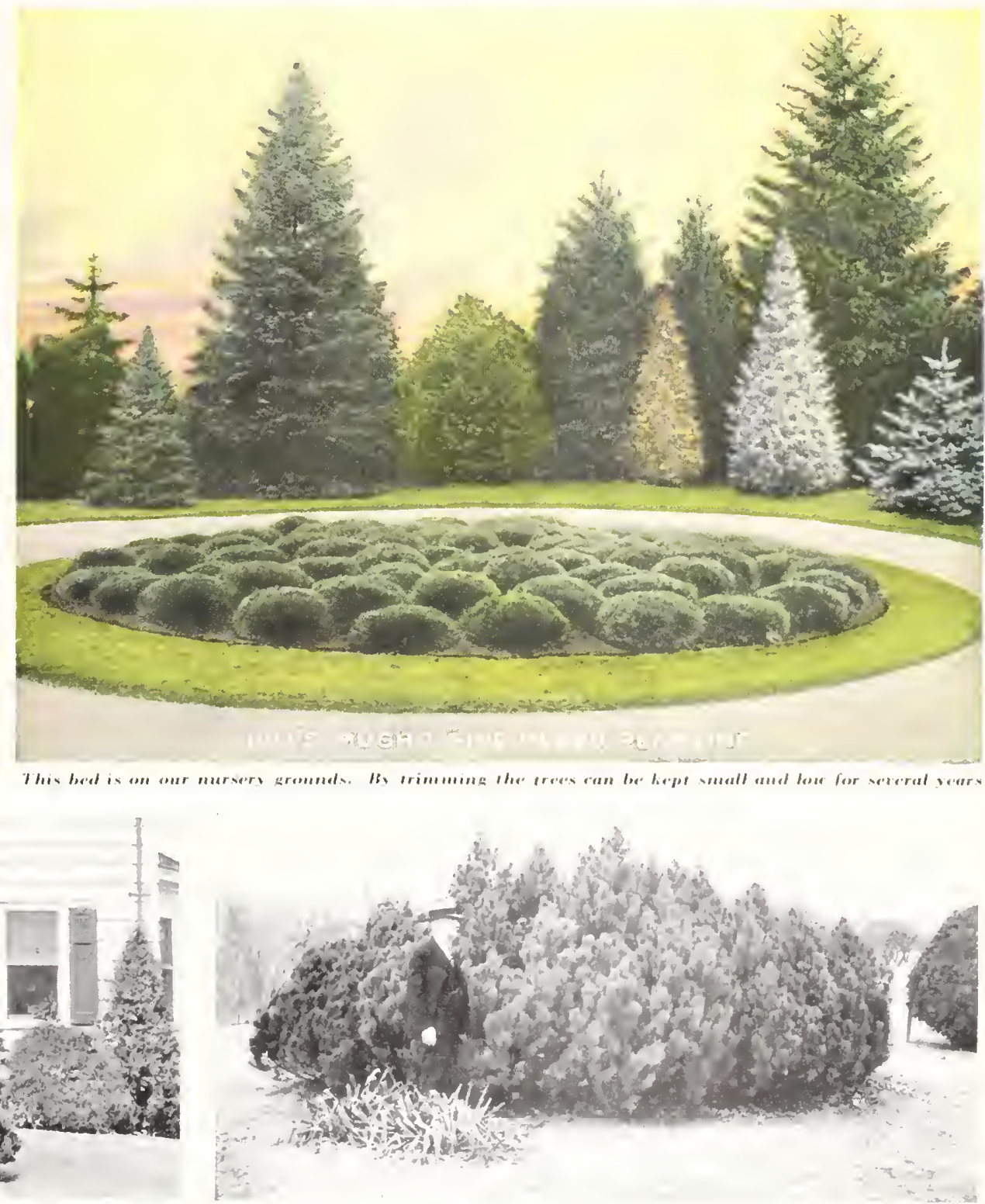


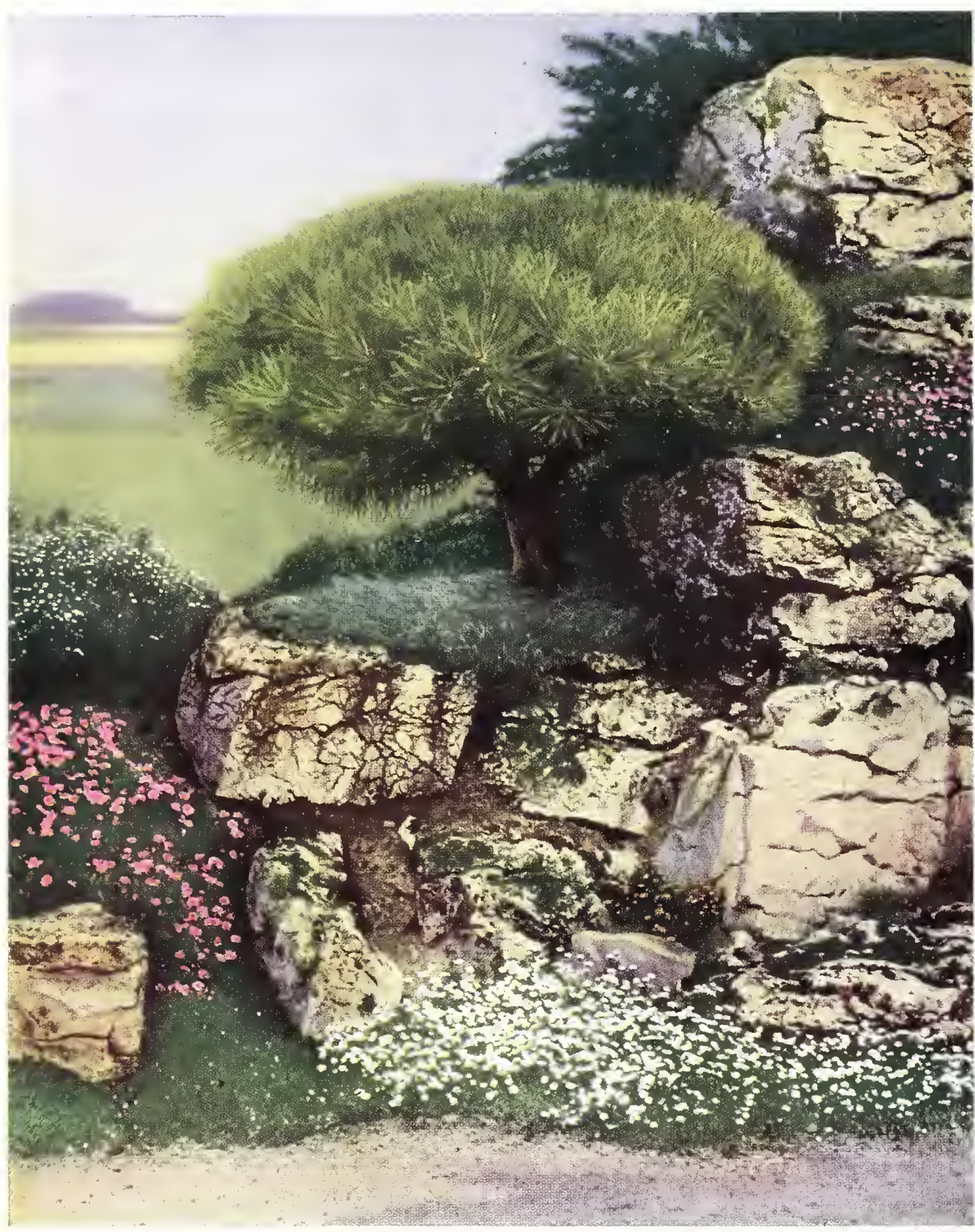

An old tree in miniature. The Japanese Table line

\section{Scotch IPine}

(Pinus syliestris)

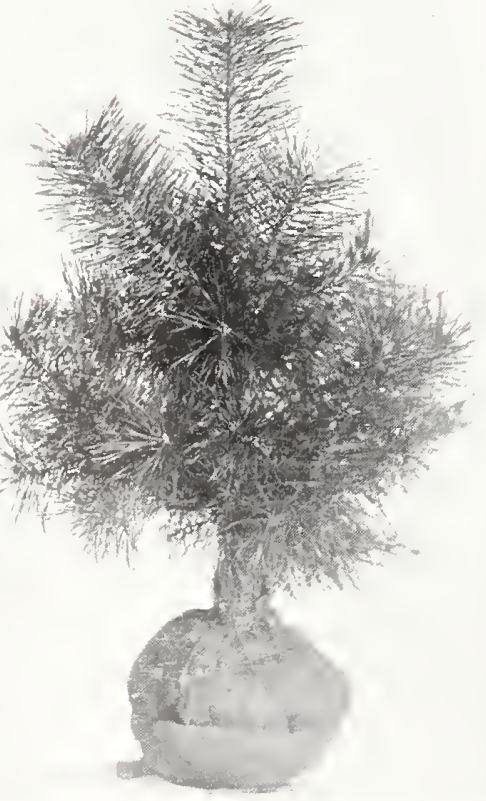

I saw far off the dark top of a pine look like a cloud-a slender stem, the tie that bound it to its native earth

Wordsworth, The Pine on Monte Mario

T HE rapidity of growth, great hardiness and the ease with which it may be

1 grown on almost all soils, has made this tree a great favorite both here and in Europe. Scotch Pine is the Common Pine of Europe where it has been a valuable tree for timber and ornament for centuries. It is familiarly known in Scotland as Scots Fir.

The needles are short, two to three inches long. Light green in color, pungent, concave on the upper surface, convex on the under side.

When young, it makes a loose but symmetrical growth. In old age it inclines more to the picturesque than the beautiful. In old trees the bark is of reddish brown color.

\begin{tabular}{|c|c|c|c|}
\hline & & $\mathrm{EACH}$ & 10 \\
\hline $11 / 2$ to 2 feet $\mathrm{xx}$ & Bit & $\$ 1.25$ & $\$ 11.00$ \\
\hline t $\mathrm{xx}$ & $B \& B$ & 1.75 & 15.00 \\
\hline $\mathrm{xxx}$ & $B \& B$ & 2.50 & 22.50 \\
\hline$x \times 2$ & $B \& B$ & 3.50 & 32.50 \\
\hline
\end{tabular}

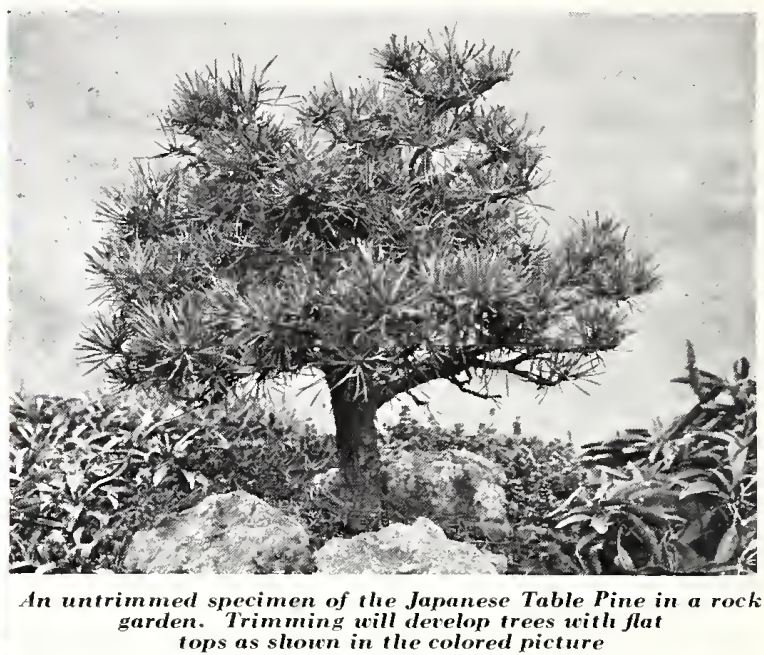

Japanese Table Pine

(Pinus tanyosha globosa)

INTERESTING DWARF FORM

T $\mathrm{T}$ has an attractive light green color with characteristic long, slim needles, soft and flexible. Our 1 original trees were imported some years ago from Japan. It is reproduced by grafting.

Dwarf forms among the Pines are not numerous. This one is especially valuable because of its unique habit, entirely distinct from other Evergreens. It grows on a short, stout trunk, branching out evenly in mumerous branches, forming a flat, table-like top.

Old trees develop a spread of three to four feet, but it remains only about two feet in height at the most.

10 to 12 inch $\mathrm{xx}$.

12 to 15 inch $x x$

15 by 15 inch xxx.

18 by 18 inch $\mathrm{xxx}$.

same variety and size at the 10 rate. Each $x$ indicate one transplanting. B\&B signifies balled and burlapped.

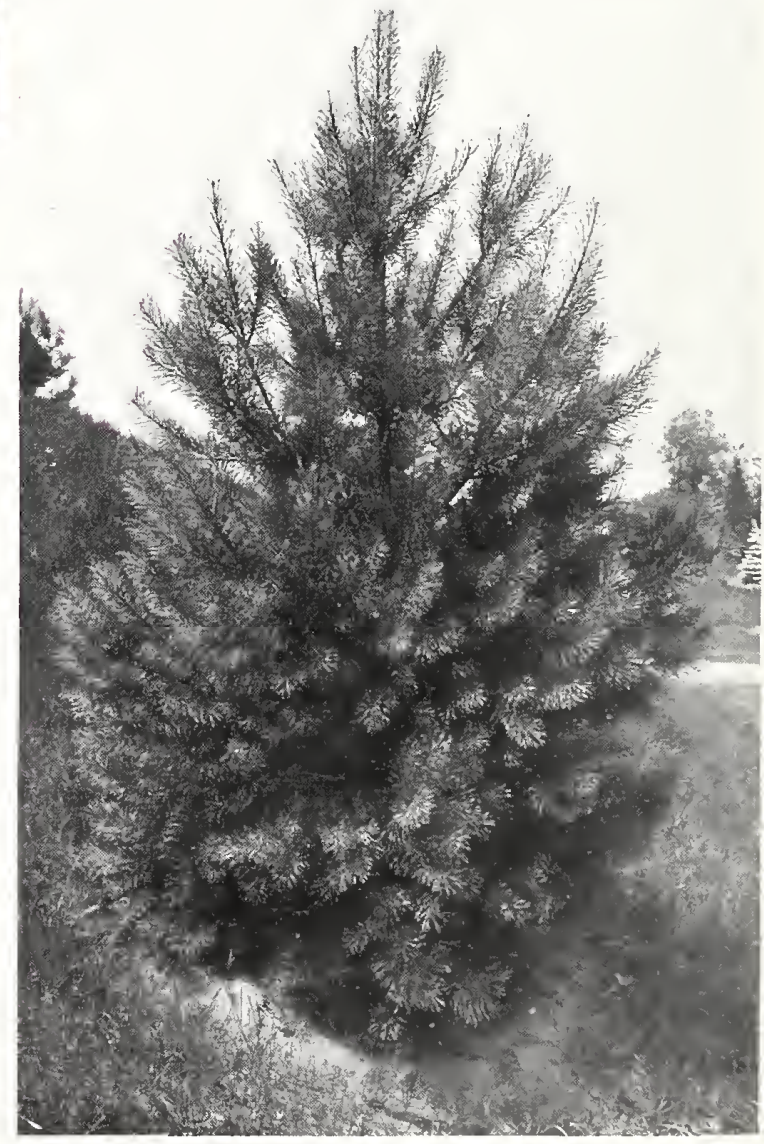

A well developed Scotch Pine. This rariety grous very rapidly 


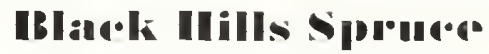

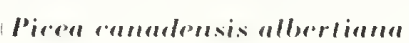

B TANICALEY, the Black Lill-spruce is comsidered a close relative of White spruce, and has developerd its dintinct chararerof South Dakota. The foliage varies from green to bluish tint, and all trees are remarkable for their bright, fresh color.

The Black Hills spruce is hardiest of all surues - smmetrieal, compact and busly in habit of growth; in fact, the very smallest trees soon form round, sturdy, compact bodies. As the tree grows and develops, it continues to carry this particular style of growth and generally hecomes the most compact-growing specimen of the spruce family.

When fully matured, it reaches 2.5 to 40 foet in height and requires 10 to 12 feet for spread of branches. For this reason it is used mainly for individual specimens, for backgromels, borders and in places away from buildings. However, as it is a sow grower, it ean remain in elose quarters for several years and is often seen in foundation planting and similar places. Situations should be selected which provide sun at least part of the day.

Mr. D. Hill was the leading introlneer of this variety to the trade, having offered it more than forty year- ago.
10 to 12 incli $x$

$11^{1}$ to 2 feet $x x$

$11_{2}$ to 2 feet $x x x$

2 to 3 feet $x x x$

3 to 1 feet $\mathrm{xxx}$

4 to 5 feet $\mathrm{xxx}$

5 to 6 feet $\mathrm{xxx}$

Vive of the same variety and
aignifie thatlest and lurlapest.

TO I TINIBEIRI,IVE TIREI

Hiph on a fondy momentain pian

lareing alome all Valure's w rillh.

Twistud ind torn by aternil storm.

Brilse with your bitrk ind your branches wern

Crippleal and lant by elernial blaste

II inning life's binttle by holdino fant

To sour place in the world as it was orditined.

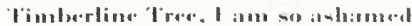

of the fight lie utide in the world of men:

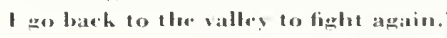

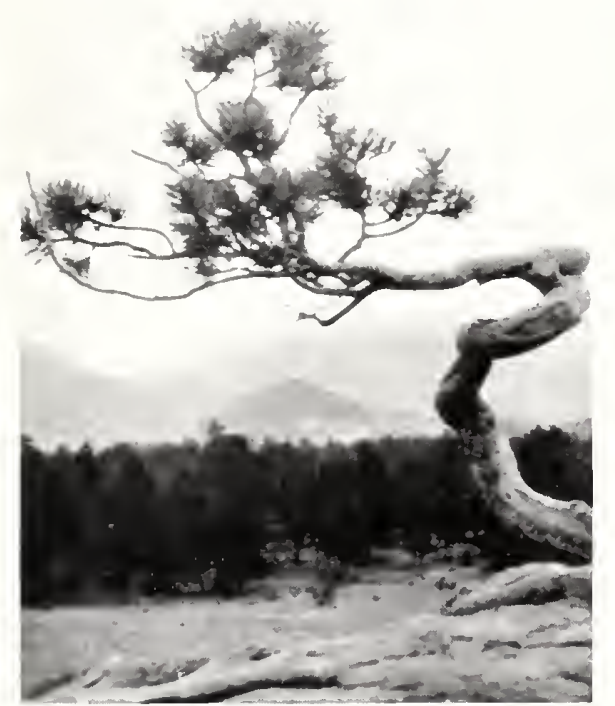

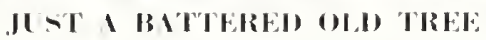

The Timberline Tree is not benutiful, if you look for brauty in symmetry, arme lush foliagye, and graseful lines. Al limes the batle heres gome against it, and the marks of man!y a defoul ato plain to be sern.

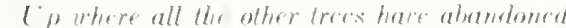
the unequal fight, the Timberlime Tree towes the farthest out pest of life. I Amon" that the Timberlime Tre is not good for fruit, nor is it of murh material uxe to the children of ment. Bul it spirit is that of the athenturer, who goess far beyond any rhances of grain or ghory. and shous uhat intrepidty can compass. I thent of it a. in some uny kin to the Lineolers among men.

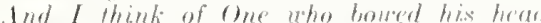
against billerer wimds than have beat on all the sons of men, but who stoort his groumd until the day when he could say, "In" the Henld gr' shall hase tribulation; but be of good cheer, I hats orerome the world!

J J'STL'S TIMBERLINE

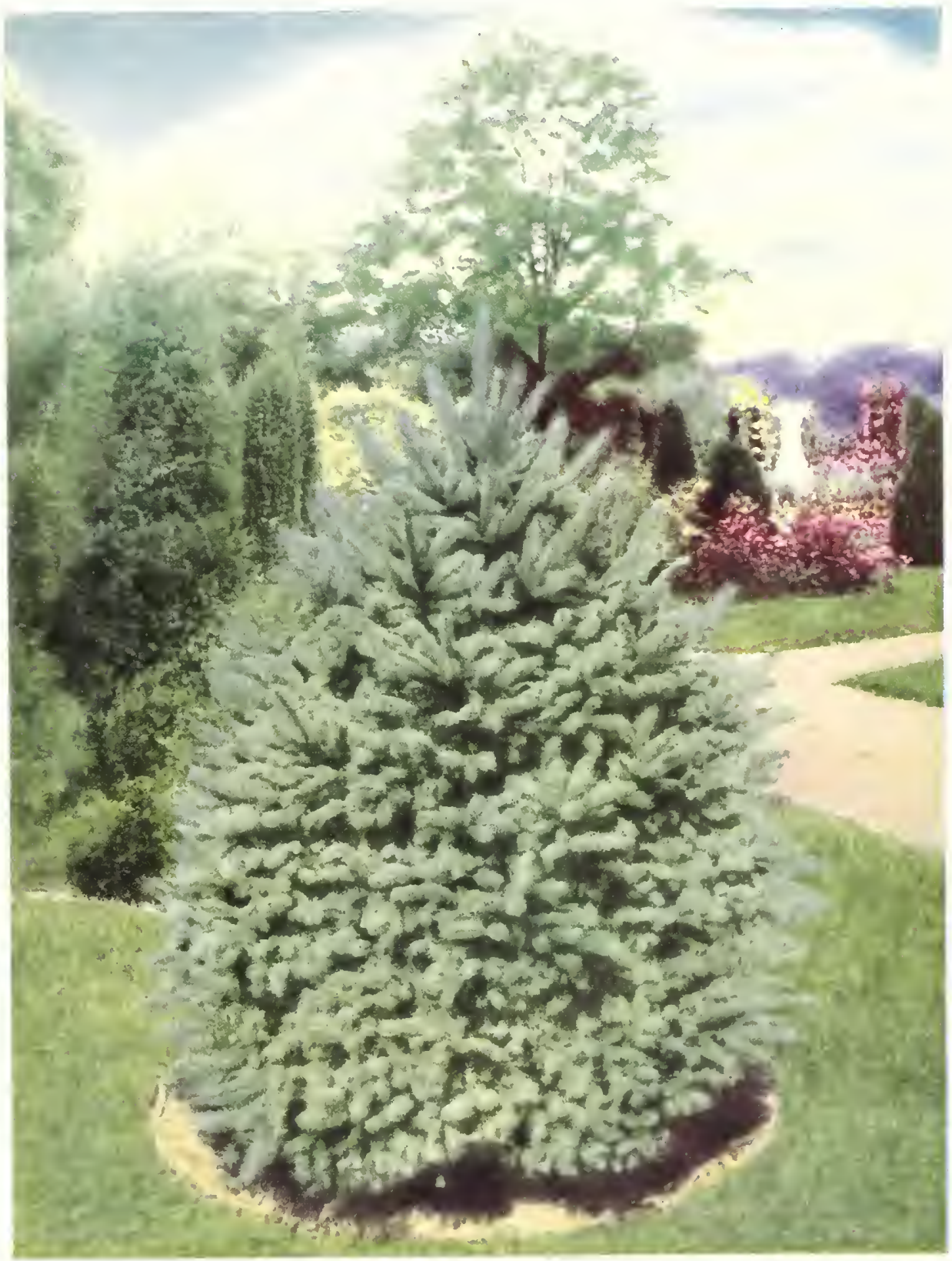

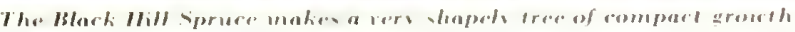

$\begin{array}{lll}2 & 11 & 0\end{array}$

Bis $13 \quad \$ 1 \quad 15 \quad \$ 1000$

IBEB $18,5 \quad 1500$

Bit. $13 \quad 200 \quad 17.50$

B.EB 4 (O) 37.50

$\mathrm{BC} \mathrm{C}+\mathrm{B}+501250$

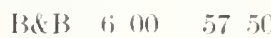

B.E B 9259000

B.E I3 $13 \quad 75 \quad 13500$ 


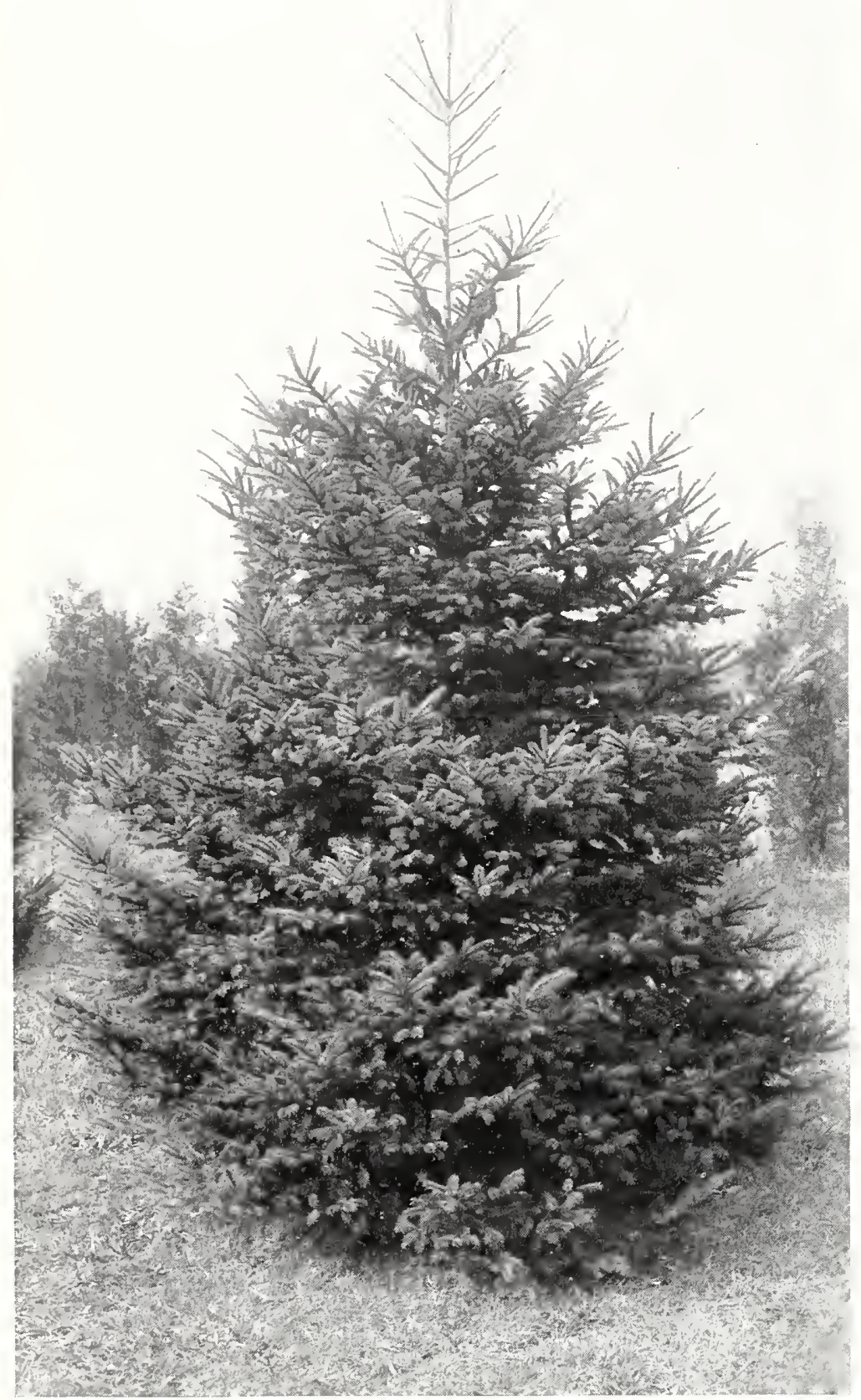

Reaching up statwart and straight, 1 hite spruces give us all we can ask for in

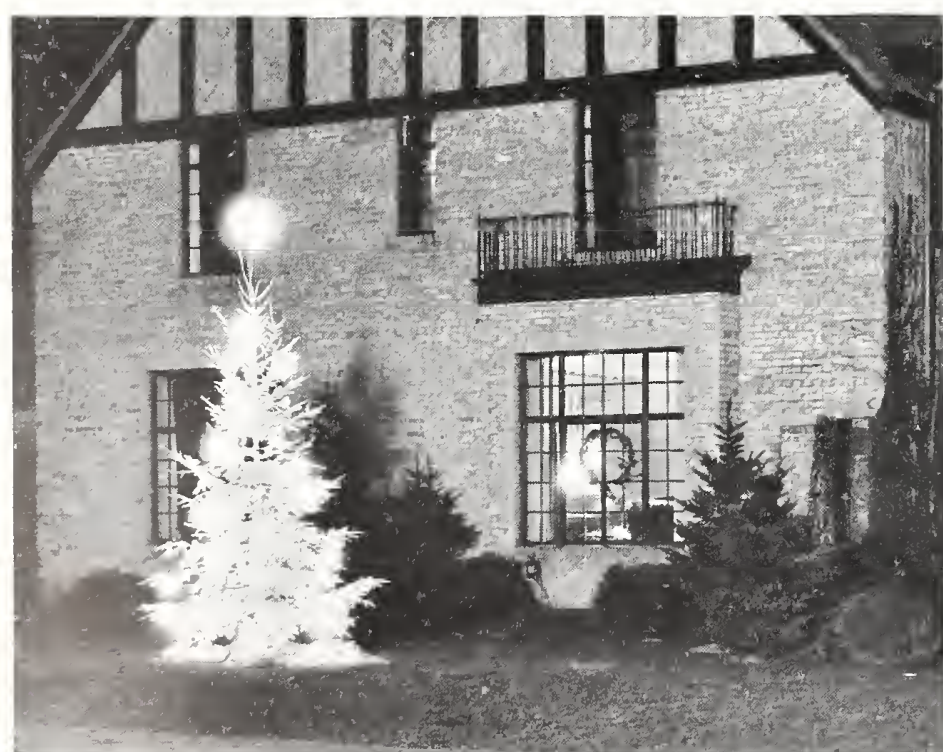

The living Christmas tree' It gives joy to the oucner and checr to all. White Spruce are ideal Christmas Trees

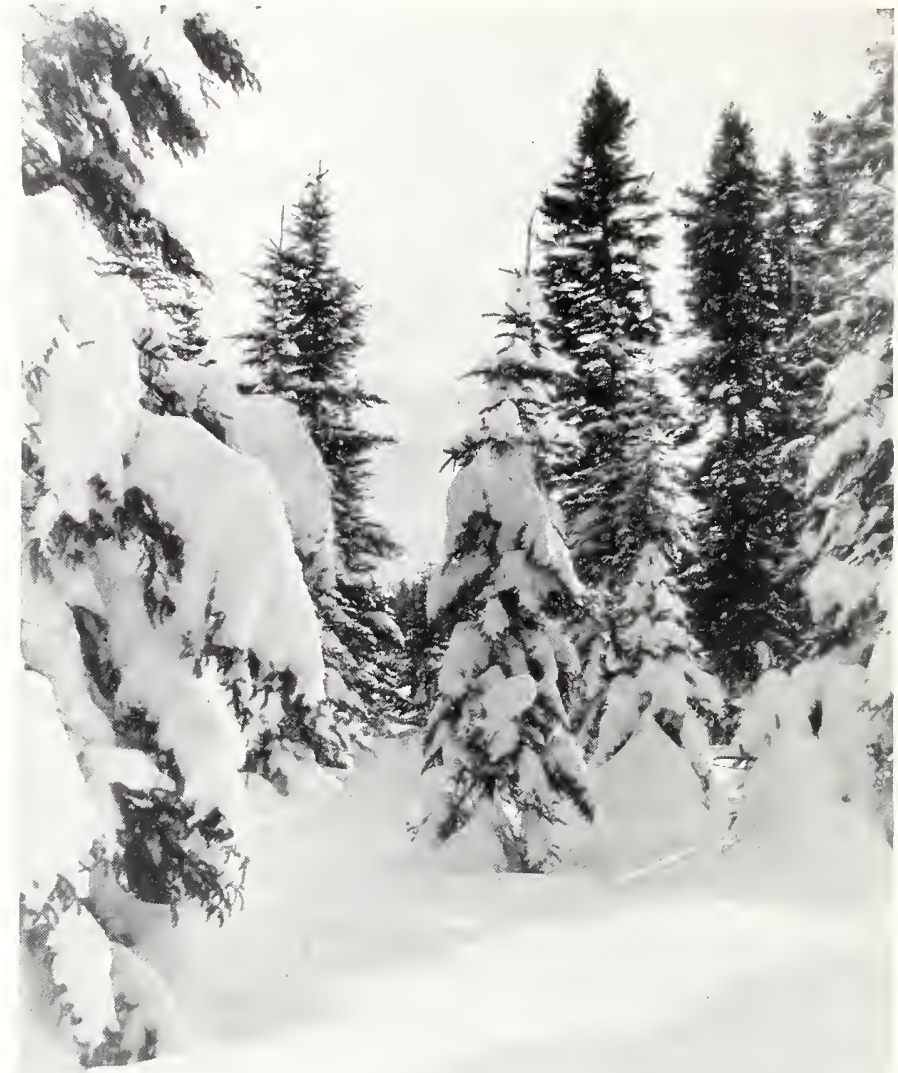

Show has bloun doun from the uings of night. Trees grow majestic under their crminc. The voung Spruce is a princess, caried

\section{American White Spruce}

(Picea canadensis)

A the last stand of the trees, within the aretic circle where we find the final vestige of tree life, the White Spruce has pushed its way. In its native stands it covers large areas in Canada on down to northern Wisconsin, Michigan and Minnesota. It grows twenty-five to fifty feet high with wicle spreading branches. Except when crowded it keeps its lower branches to the ground.

It is a native of cold climates and thrives best north of the latitude of St. Louis.

By nature it is a symmetrical and shapely grower, making a handsome pyramidal tree when small and a graceful, tall and impressive tree at maturity.

The needles are quite short, sharp, pointed and of a bluish green color. It grows fast, sometimes makes a growth of two feet a year when established.

White Spruce is especially suitable for tall backgrounds, screens, windbreaks and shelters. For single specimens, 12 to 15 feet should be allowed for the spread of the branches. It will also stand severe trimming and is for this reason often used for hedges.

1 to $11 / 2$ feet $x x .$.
$11 / 2$ to 2 feet $x x$.
2 to $21 / 2$ feet $x x$.
2 to 3 feet $x x x$.
3 to 4 feet $x x x$.
4 to 5 feet $x x x$.

$\begin{array}{ccc} & \text { EACH } & 10 \\ \mathrm{~B} \& \mathrm{~B} & \$ .85 & \$ 7.50 \\ \mathrm{~B} \& \mathrm{~B} & \mathbf{1 . 5 0} & 13.50 \\ \mathrm{~B} \& \mathrm{~B} & 1.85 & 17.50 \\ \mathrm{~B} \& \mathrm{~B} & 3.00 & 27.50 \\ \mathrm{~B} \& \mathrm{~B} & 4.50 & 42.50 \\ \mathrm{~B} \& \mathrm{~B} & 6.50 & 62.50\end{array}$

Five of the same variety and size at the 10 rate. Each $x$ indicates one transplanting. B\&B signifies balled.'and burlapped.

\footnotetext{
"Old man." cried a fellow passing near.

"You are wasting vour streneth with planting here,

Your journey will end with the ending day

And you never acain will pass this way.

You have erossed the chasm deep and wide.

Why plant a tree at eventide?",

And the planter raised his old grey head,

"Good friend. on the pat $\mathrm{I}$ h have come," he said,

"There followeth after me today

A youth whose feet will pass this way

He has not cone to the twilight dint,

Good friend, I am planting a tree for $1 / \mathrm{i}$.',
} 


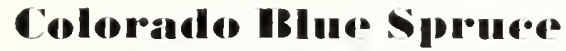

(Pirea pungens glatura)

$\mathrm{C}$ OLORADO BLEE SPRTCE i : so well known that almost everyone knows it and admires it the trees develop int bue seeiment the larme number are green or only slightly bluish tint. The bhe trees offered here are those selected an the bent blue speeimens out of blocks of thousands of trees. This aecounts for the extra cost of the blue tree.

The blue eolor is brightest in the late spring when the new growth develops. The color gratually change during the season until only a bluish tint remain. We make mention of this fact so that eustomers will not be disappointed in their trees upon arrival. The eolor of the Blue spruee is the same as the "bloom" or sheen on a grape or plum, it is a powdery sulstance that may be wiped off the needlew. This accuunt for the trees losing color after a hard winter of nnow and

The Blue spruce should be planted as a sperimen tree in the open sun away from other trees and buildings, where it will develop into a marvel of rich heauty.

SELECTED BLLE SPECIMENS

15 to Is inch $x x$

$1 \frac{1}{2}$ to 2 feet $\mathrm{xxx}$

2 to $21 / 2$ feet $\mathrm{xxx}$

GREEX COLORADO SPRECE

\begin{tabular}{|c|c|c|c|}
\hline & & E.ACH & 10 \\
\hline 1 to $11 / 2$ feet $x \mathrm{x}$. & $\mathrm{BAB}$ & $\$ 150$ & $\$ 1250$ \\
\hline $1 \frac{1}{2}$ to 2 feet $\mathrm{xx}$. & $B A B$ & 200 & 17.50 \\
\hline 2 to $21 / 2$ feet $x \times x$. & $\mathrm{BEB}$ & 325 & 30.00 \\
\hline $21 / 2$ to 3 feet $x x x$. & $B A B$ & 425 & 40.00 \\
\hline 3 to $31 / 2$ feet $x \times x$ & $B \& B$ & 5.25 & 5000 \\
\hline $31 / 2$ to 4 feet $x x x \ldots$ & $\mathrm{BAB}$ & 6.25 & 60.00 \\
\hline
\end{tabular}

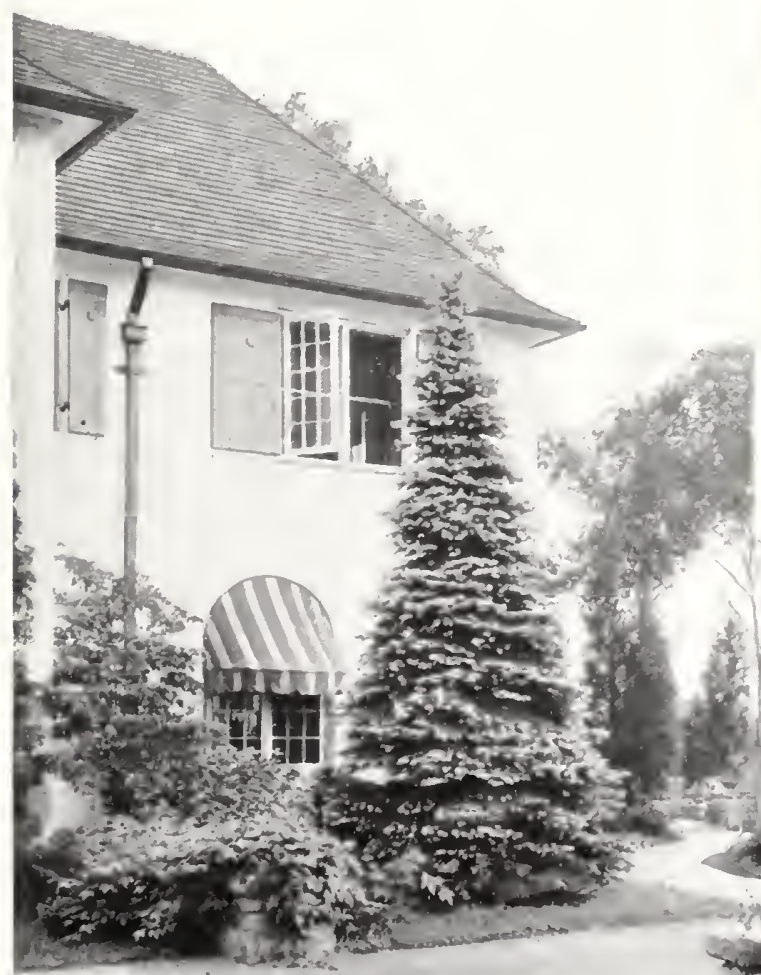

\section{COLORADO BLUE SPRUCE}

A TRIUMPH IN EVERGREEN GROWING
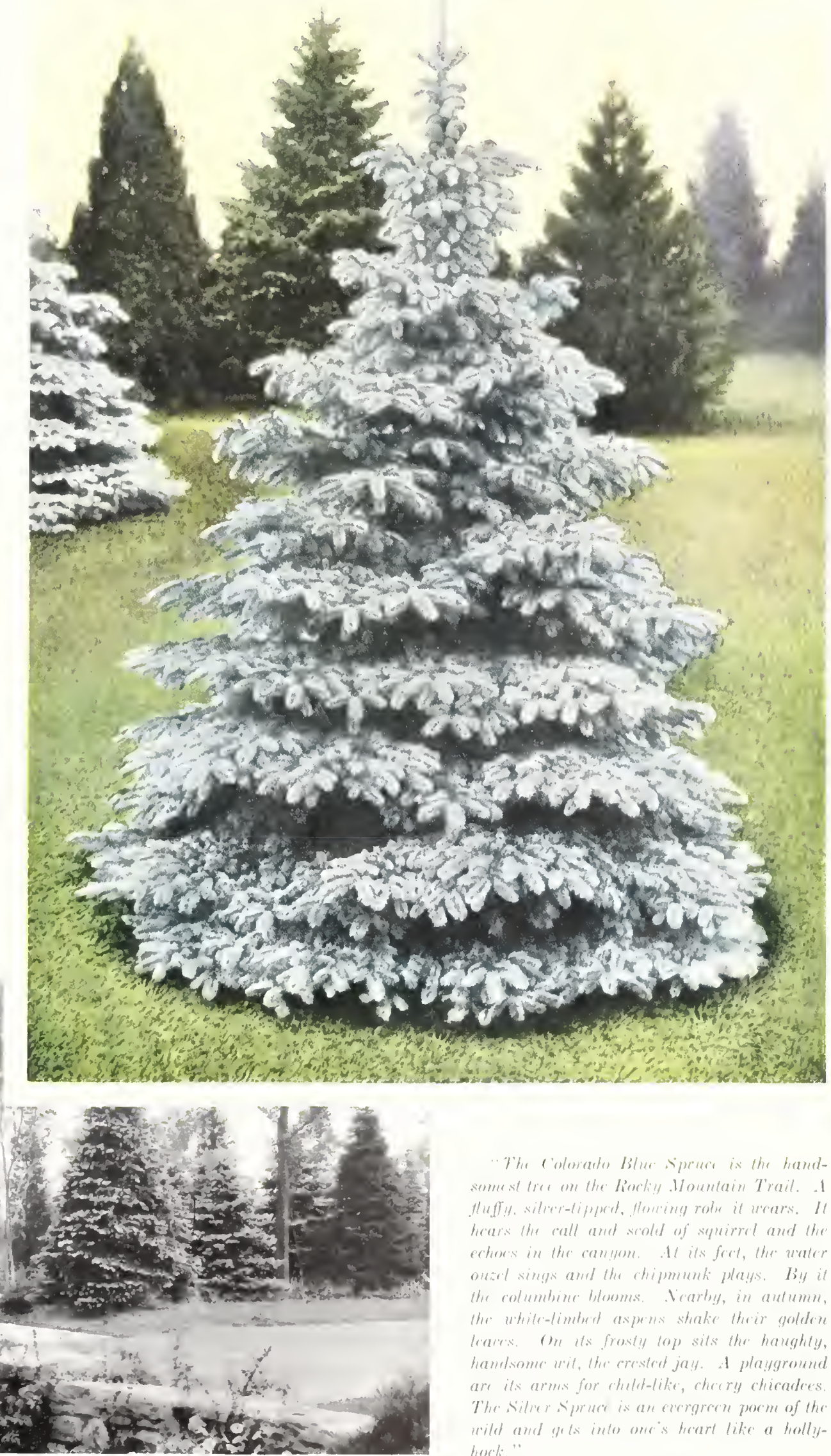

Colurado blue spruces anin the adruiration of all locers of treses 


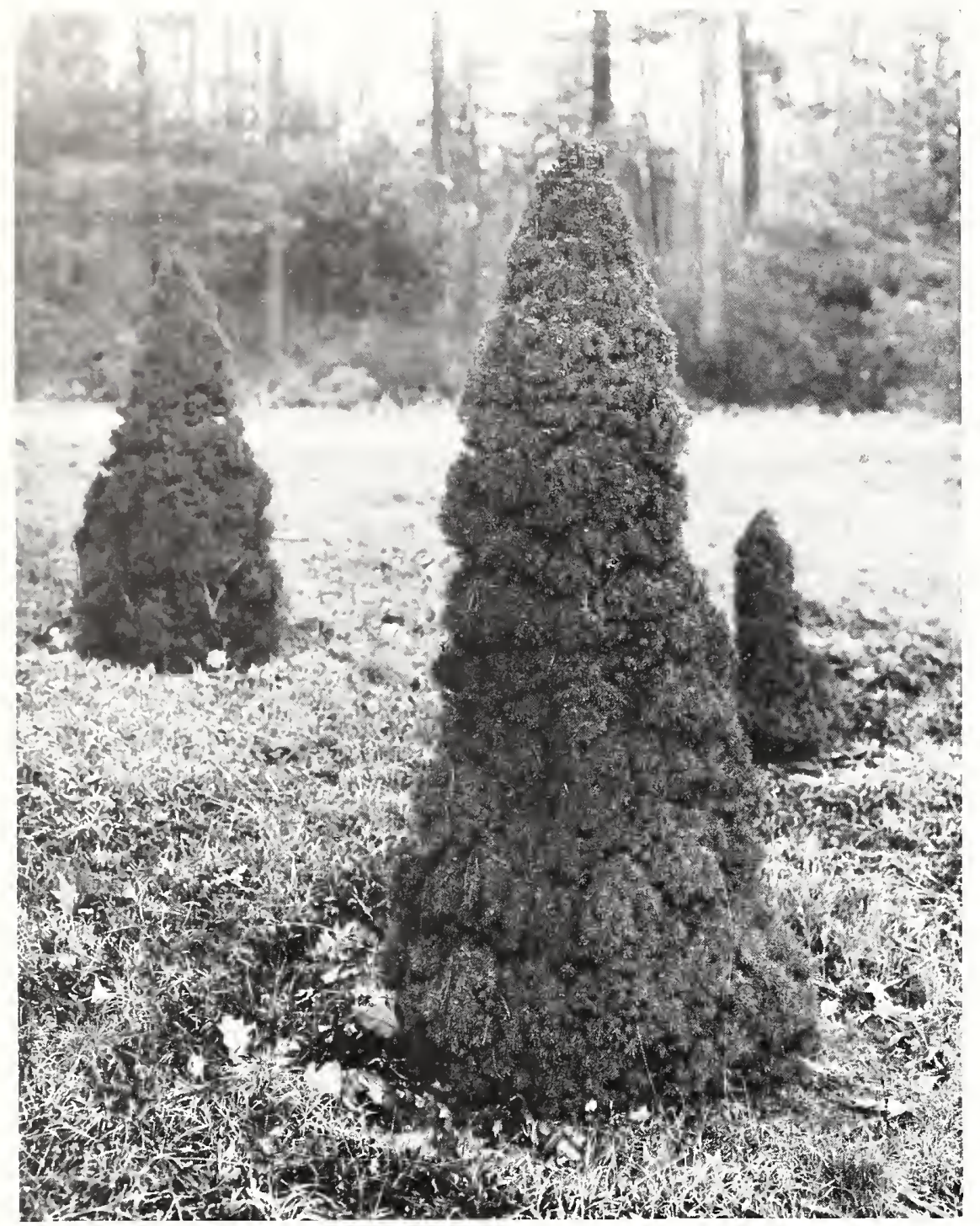

\section{Dwarlf Alberta Spruce}

(Picen Conica Glauca)

$\mathrm{O}$

$\mathrm{E}$ of the most interesting oddities among Evergreens. It is of extremely narrow, pyramidal growth, thickly covered with short, close set twiggy branches and clothed in grass green leaves. It is unlike any other Evergreen, both in shape and general appearance so that it always attracts attention.

The parent tree is in the Arnold Arboretum, at Jamaica Plain, Massachusetts. It was found in the Canadian Rockies at Lake Laggan in 1904, by Mr. J. G. Jack, of the Arnold Arboretum staff. Its annual growth is only one-half inch to one inch so that many years are required to raise the trees in the nursery. As it must be grown by small cuttings or grafts, at lcast ten to twelve years growth is represented in the sizes shown here.

Some of the oldest trees in the country are said to be about five feet high, still retaining their characteristic habits

It is perfectly hardy in this climate, but there is only one danger for which we must look out. If exposed to the south this little tree may be burned by the winter sun and winds. snow which easily collects in the dense branches will, if melted by the sun, change to ice and have the effect of a lens. No serious damage will then result, except a browning and shedding of some of the needles. It is advisable, therefore, to shade it toward the south during winter. This is easily done by fastening a piece of burlap to two stakes, setting at the south side of the trees. It prefers a partially shaded, rather moist location, and winter protcetion is then unnecessary. We can speak from experience as we have tested a group of trees on our own grounds for the last eleven years.

Many planting uses suggest themselves for this little tree. For formal efiect in terraces and gardens and rock gardens, it is proving of great interest and value.

ЕACH 10

8 to 10 inch $\mathrm{xx}$

$\mathrm{B} \& \mathrm{~B} \$ 2.50 \$ 22.50$ Five of the same variety and size at the 10
planting. B\&B signifies balled and burlapped.

Duarf Alberta Spruce, grouing on an estate in

\section{Nest-Slaaped Spruce}

(Picea excelsa nidiformis)

$\mathrm{F}$

YOR want of any authorized common

name we have given this tree a literal

translation of its botanical latin name.

It was found in cultivation near Hamburg, Germany, and described by the introducer in 1906 as "a round plate-like, fanforming form with a dense nest-like mass of branchlets where the leading shoot should

It is of such extra ordinary dense form, so densely branched that one wonders how the light ever gets to the lower branches. Branchlets in tight layers, the whole forming a dense impenetrable head.

It grows slowly, $3 / 4$ inch to $13 / 4$ inch yearly This is one of the few truly dwarf Evergreens. Ultimate size is a matter dependent entirely upon conditions.

B\&B $\begin{array}{cc}\text { EACH } & 10 \\ \$ 2.50 & \$ 22.50\end{array}$

Five of the same variety and size at the 10 rate. Each $\mathrm{x}$ indicates one transplanting. B\& $\mathrm{B}$ signifies balled and "WITCHES-BROONS"

Many dwarf forms of Spruce have originated from sports on branehes of an otherwise normal tree. conglomerat tions of branchlets that occur at times On trees and familiarly known as "witches-brooms. insect irritation or sap constriction. It has been found that cuttings or grafts taken from such "Dwarf and Slow f, rowing Conifers." Hornebrook

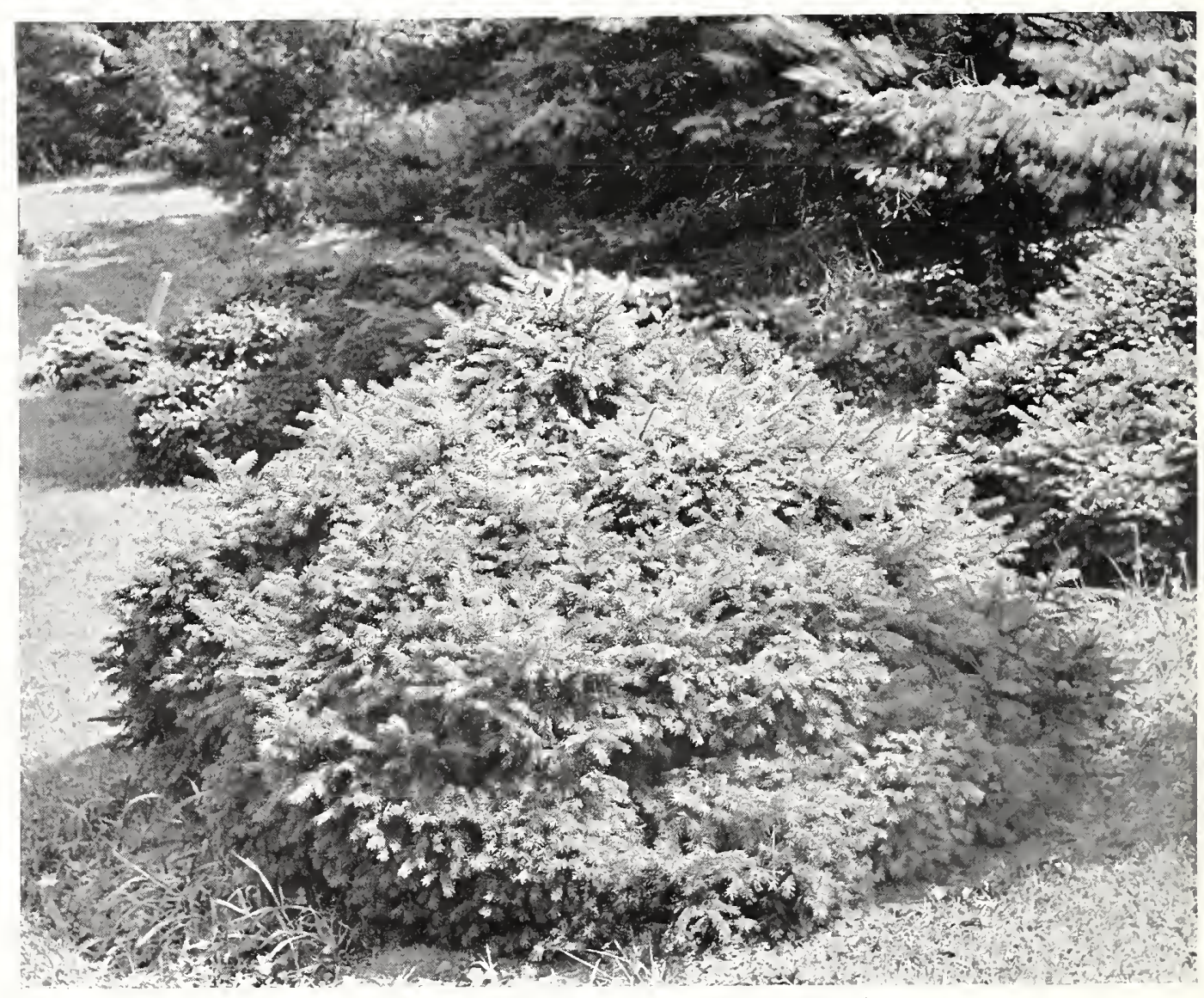

The Nest-Shaped Spruce (Picea excelsa nidiformis) 


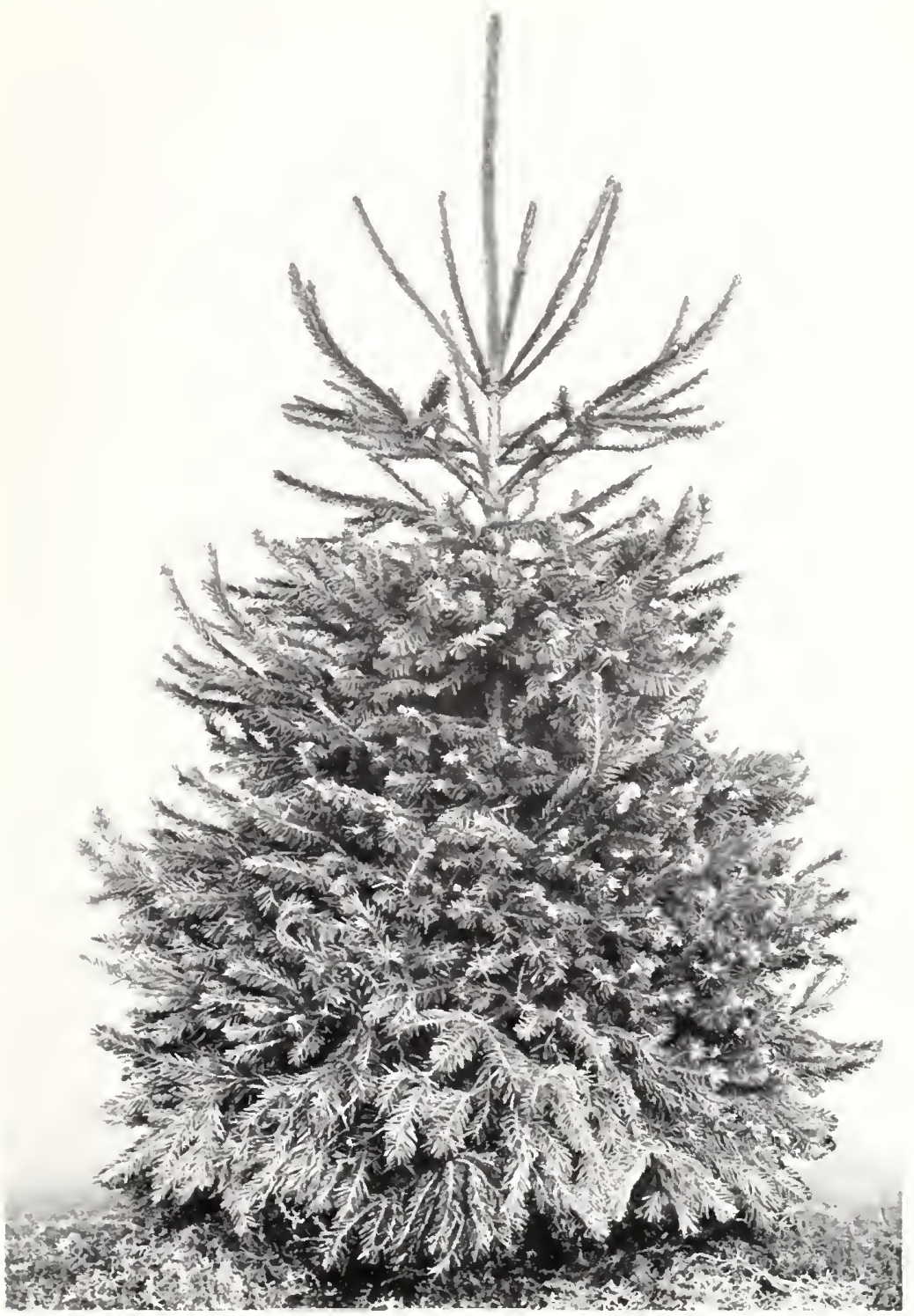

There is a growing preference for Chrismas Trees which have been produced locally. There are several reasin: for this. One reason, probably the most important, is the fact the trees retain their foliage throughout the holiday season. They are usually eut a week or so before Christmas and if kept in a cool place will not shed their needles even though brought into a warm house and left for a week or ten days.

There is also a great arlvantage with

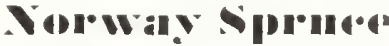

Piere excelse
$\mathrm{N}$

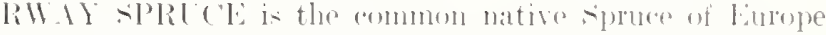
and is fonmel in Rusia, Norway, swerlen, l) fonmark, Ciemany, switzertand, France and slsewhere. This wirle range of cored upply aceount for the behavior of the tree in this country. It is exential that serel come from the most desirable sourese to misure -atisfactory results in America

The sharp, pointed leaves are an inch or less in length and dark areen in color. The general habit is tall, with regularly branchel layer or whorls of hranches. It branches elose to the ground and nakes a slightly sweeping or frooping appearanee. The growth is rapid; muler favorable conclitions, it will grow one to two feet each sasison.

(Tor large sections of Ameriea the term "everereen" is almont

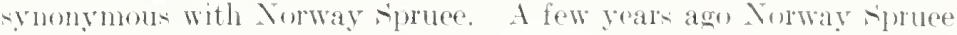
was probably the most widely used Evergreen. Fvon at the prosent time it is doubtful if any evergreen is producal and whl in such quantities as Norway seruce. The tondeney to plant it seems to be lexsening a little nowadays. More variotios of erorereon are arailable flom nureries and it is only human nature to want to get away from raritios that are "('ommono."

$1{ }^{1}$, to 2 feet $\mathrm{xx}$

E.A'II 10

2 to 3 feet $x x$

B. B $\$ 1 \quad 15 \$ 1000$ BiEB $165 \quad 1500$

Five "f the satue varieg and aize

\section{Profits in IBaising Cluristmas Treas}

I

$\mathrm{T}$ is estimated that five million Christmas. Trees are need in the Inited states every year. The use of the Christmas Tree is a well

established eustom in every section of the enuntry and is treing continued in even greater numulers year after vear.

Crowing Christmas Trees in plantations near the large consuming eenters is an attractive busmess proposition. This is particularly true for center in the Ea-tern and Middle ifectern states which are rather distant from a natural source of supply. Several such plantations are already in existence. In a plantation adjacent to a gond publie road, all trees roukd be sold right on the ground to people pawing in automobiles.

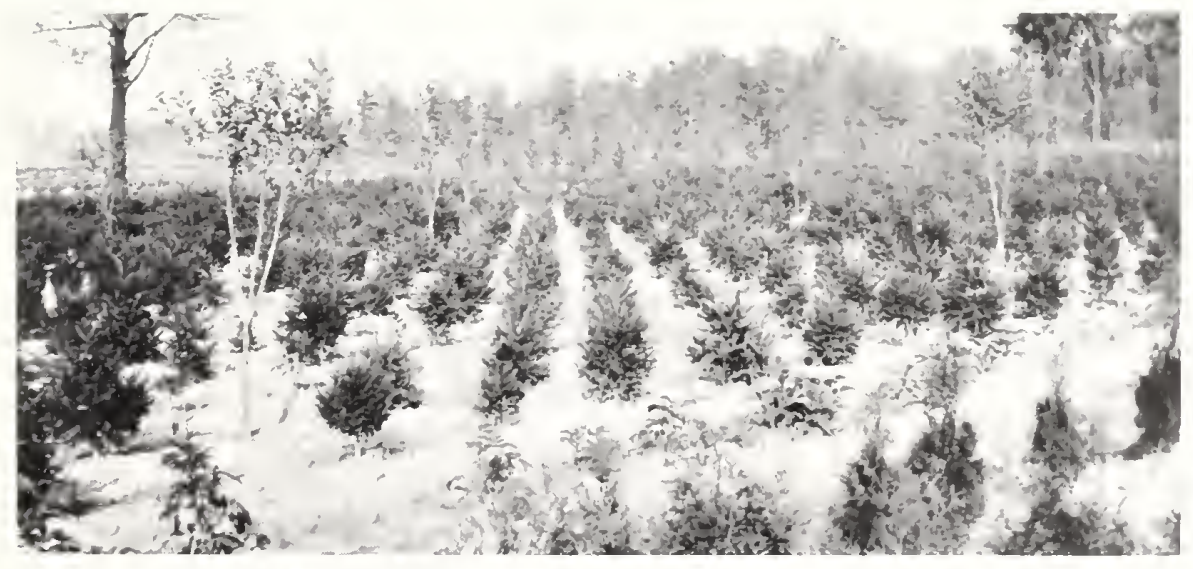

the hone grown trees in the general shape and character of the trees. Those pro(lueed at home have a thriftier appearanee and are apt to be of much botter shape.

Trees usually planted are Norway sipruce. They can he lined out clirectly into field row and if cultivated the first year or two they will auckly bocome entablisherl.

Finther detaik will gladly be rent on request and prices ruoted for varions quantities of planting stock. 

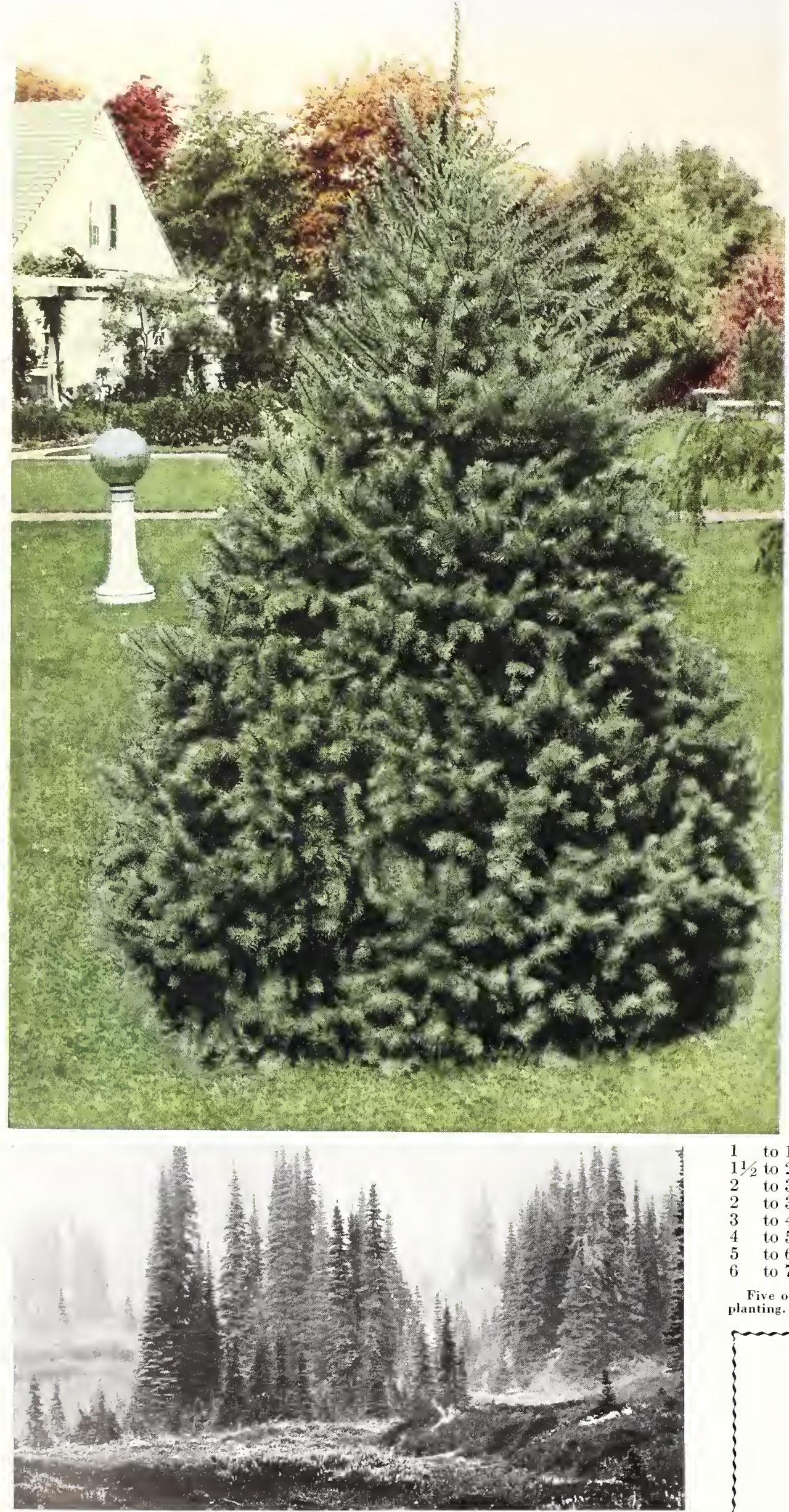

1 to $11 / 2$ feet $\mathrm{xx}$

$11 / 2$ to 2 feet $x x$

2 to 3 feet $x x$

2 to 3 feet $\mathrm{xxx}$

3 to 4 feet $\mathrm{xxx}$

4 to 5 feet $\mathrm{xxx}$

$\begin{array}{lll}5 & \text { to } 6 & \text { feet } \mathrm{xxx} \\ 6 & \text { to } 7 & \text { feet } \mathrm{xxx}\end{array}$
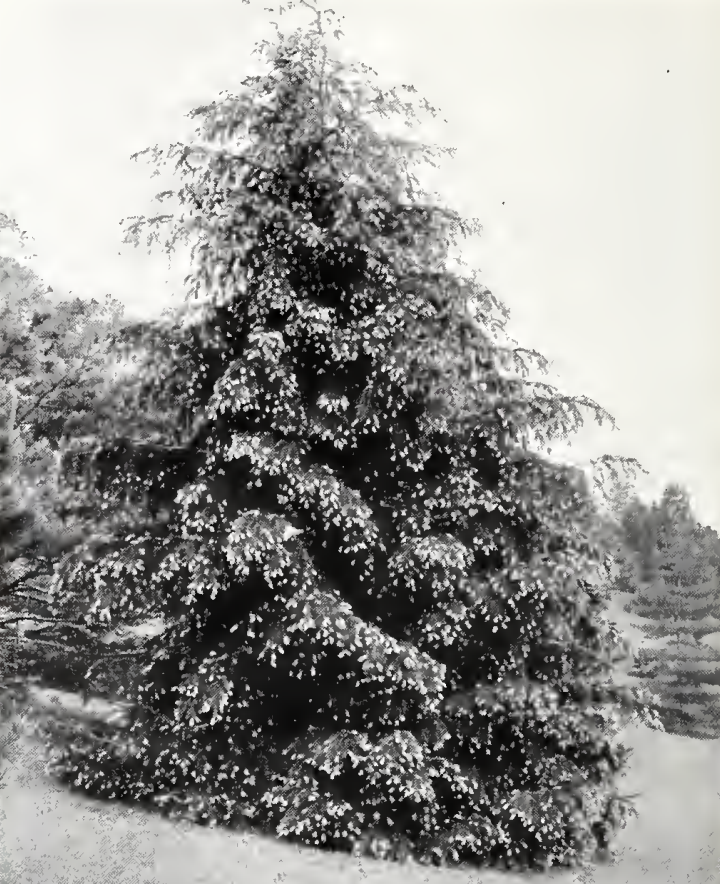

Douglas Fir just beginning its armual Spring grouth, dis.

playing its soft and new lips

\section{Douglas Fir}

(Pseudotsuga douglasi)

DHERE are two distinct forms of Douglas Firone the dark green, gigantic-growing timber tree of the Northwestern Pacific Coast area, and the other type from Colorado. The latter variety is the one recommended, both for its hardiness and its reat beauty.

The typical form of young trees is an open, broad, harp-pointed pyramid; the lower branches are higher ones trend upward.

Our plants are the type from northern Colorado, the seed being collected in deep gorges of high altides, where the blue and silvery foliage is charactertic. The growth is compact and symmetrical with short necdles.

After many years it reaches 60 feet or more in height, with a spread of branches 12 to 18 feet. It is a rapid grower and thrives well in almost any situation. The with plenty of room for future development.

ance, and pcrmanency. The Firs are among the randest of nature's triumphs. Five of the ane variet and sine at the 10 rate. $\mathrm{Each} x$ indicates one trane. B B Bignifies balled and burlapped.
10 $\$ 1.15 \$ 10.00$ B\&B $\quad 3.50 \quad 32.50$ B\&B $6.00 \quad 57.50$ B\&B $8.50 \quad 82.50$ B\&B 10.50100 .00 B\&B 16.00155 .00 B\&B $\quad 2.00 \quad 17.50$

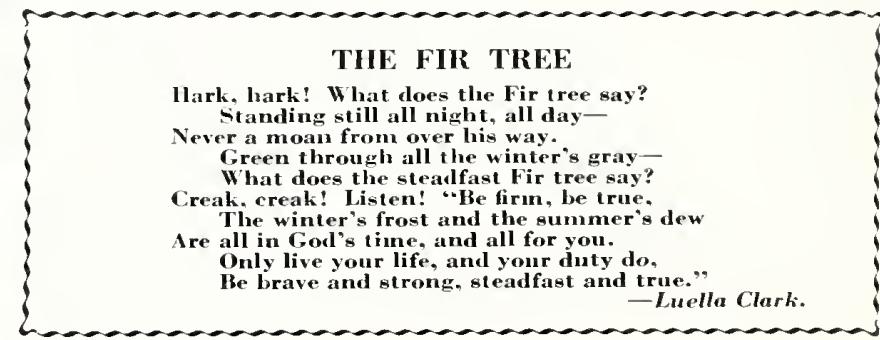




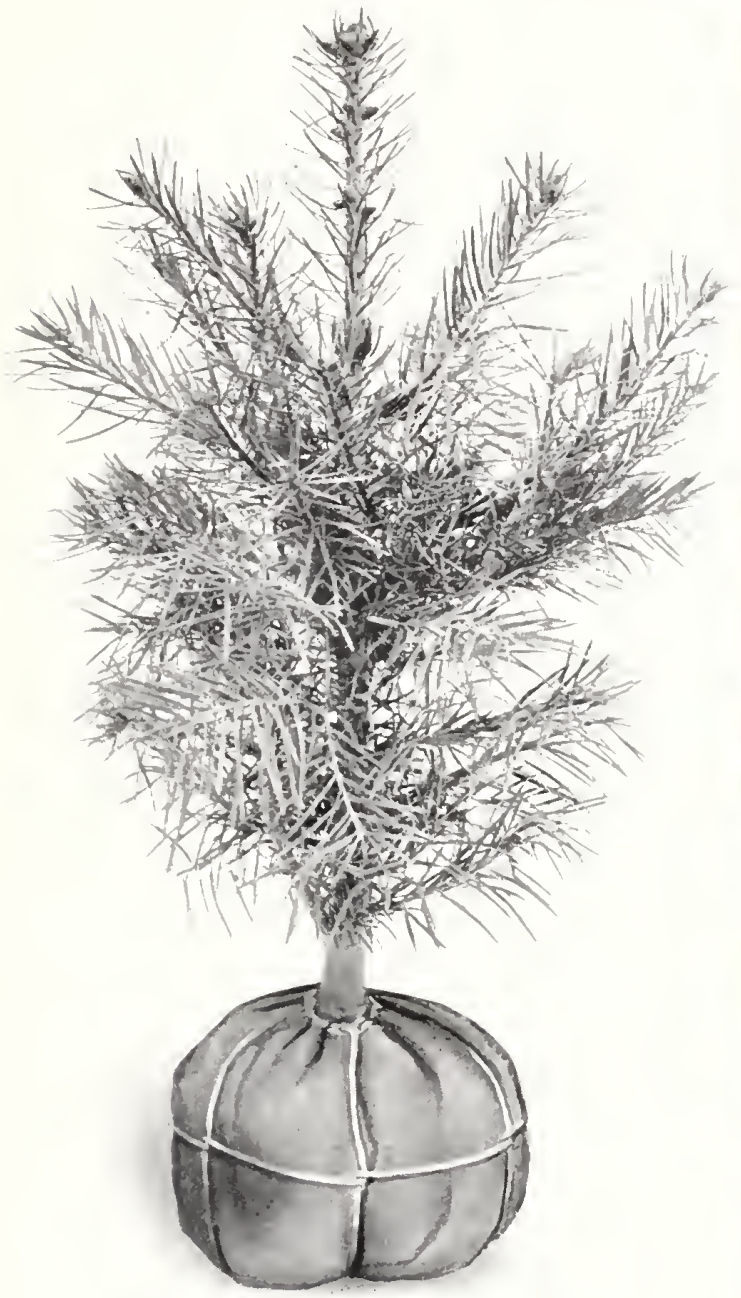

\section{White or Comentor Nir}

dbies concolor

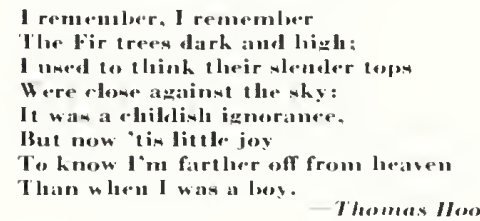

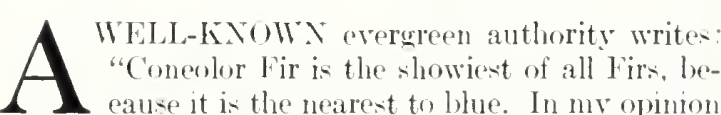
it is the cheeriset of all evergreens in winter. It retain its lower branches, ancl is the best Fir tree to withstand heat and (lrought." As an ornamental tree, Coneobr Fir is excellent, the general outline leeing symmetrical but without stiffiness. The spread of

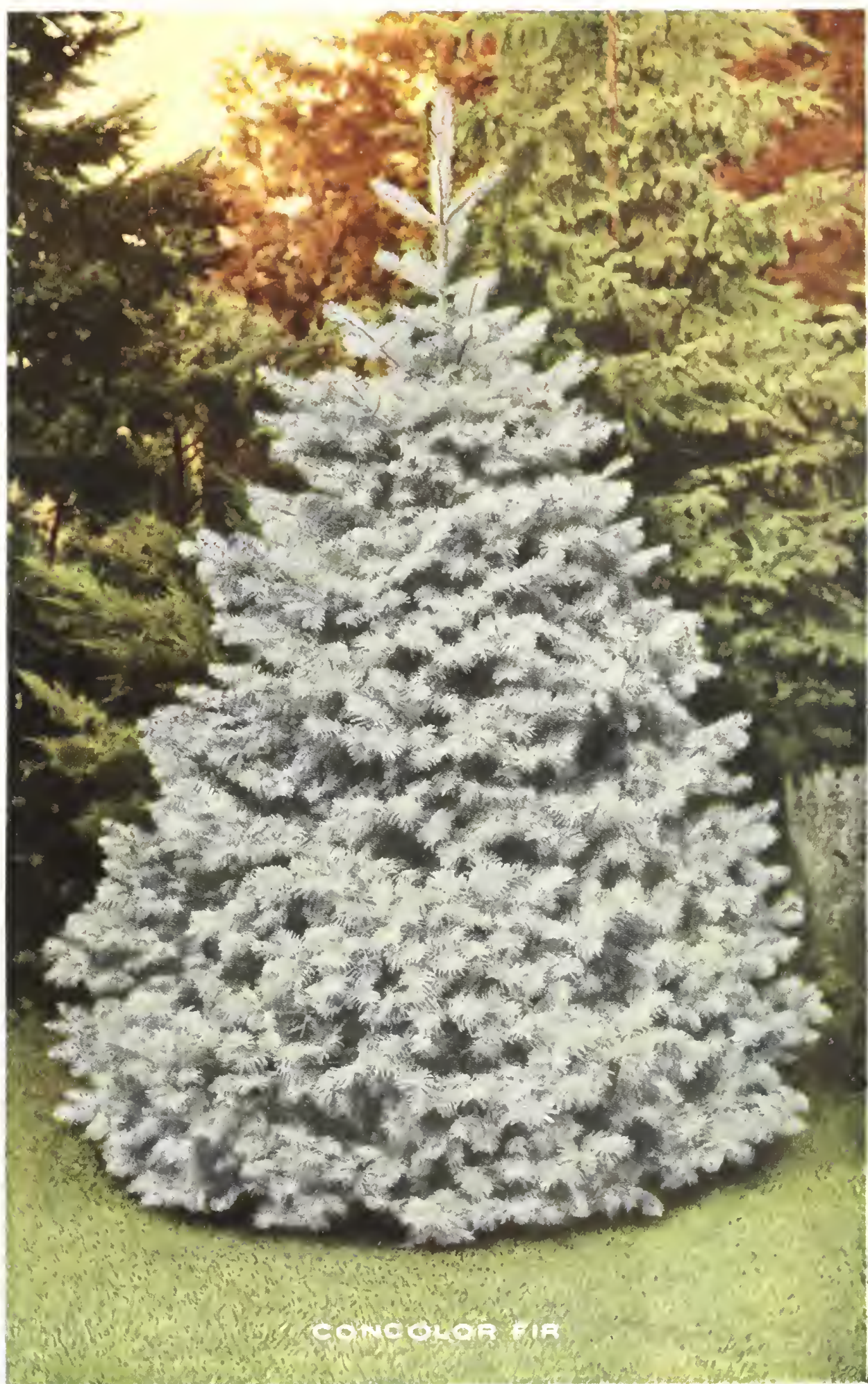
branches in roune and healtly trees, being wide in proportion to the leeight, warns intending planterthat sufficient suaee should be wiven for porfeet

derelopment. The form from colorado is loest addapterl to planting. It retains a distinetly pramidal outline and is branched to the base. Thes large, flat leares, thiekly disposed on the linnehes, are rery noticeable and give it a very dignified appearaner.

The name "Concolor," given to this tree by lor. Lngolmann, who discovered it about 1sio, signifies even eolor- loth the upper and under sides of the needles are beautiful grayish-blue. Many years ago, Mr. In, Hill, while on a visit to the Colorarlo Rockies, was keenly impreserl with the distinetive attractivenes of the concolor Fir. Chiefly through hieffort- this beautiful Fir has bren introduced to Amerian planters. Concolor lir is also known as "silver tir" and "White Fir."

We obtain our seed-supply from northem Colorado, which produce trees of absolute laardinese, with striking foliage varying in eolor from light green to (leep soft blue.

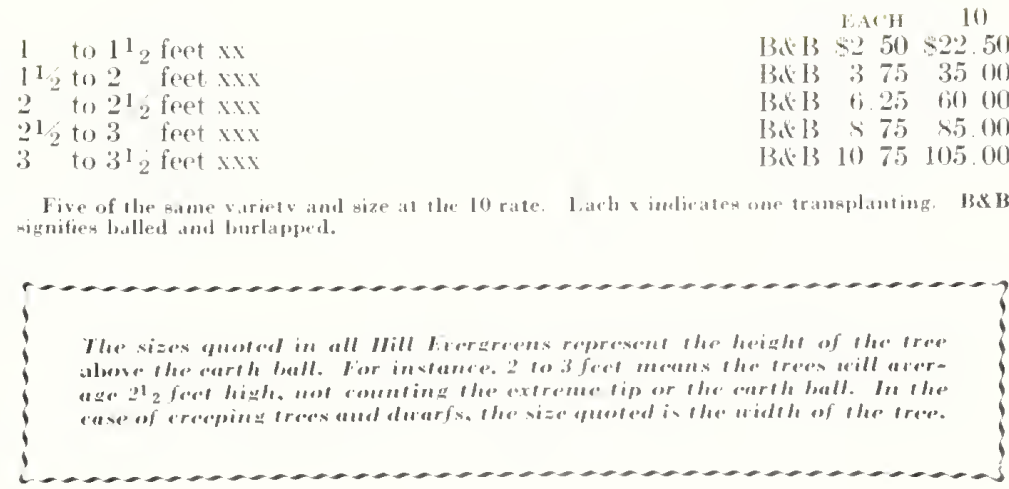




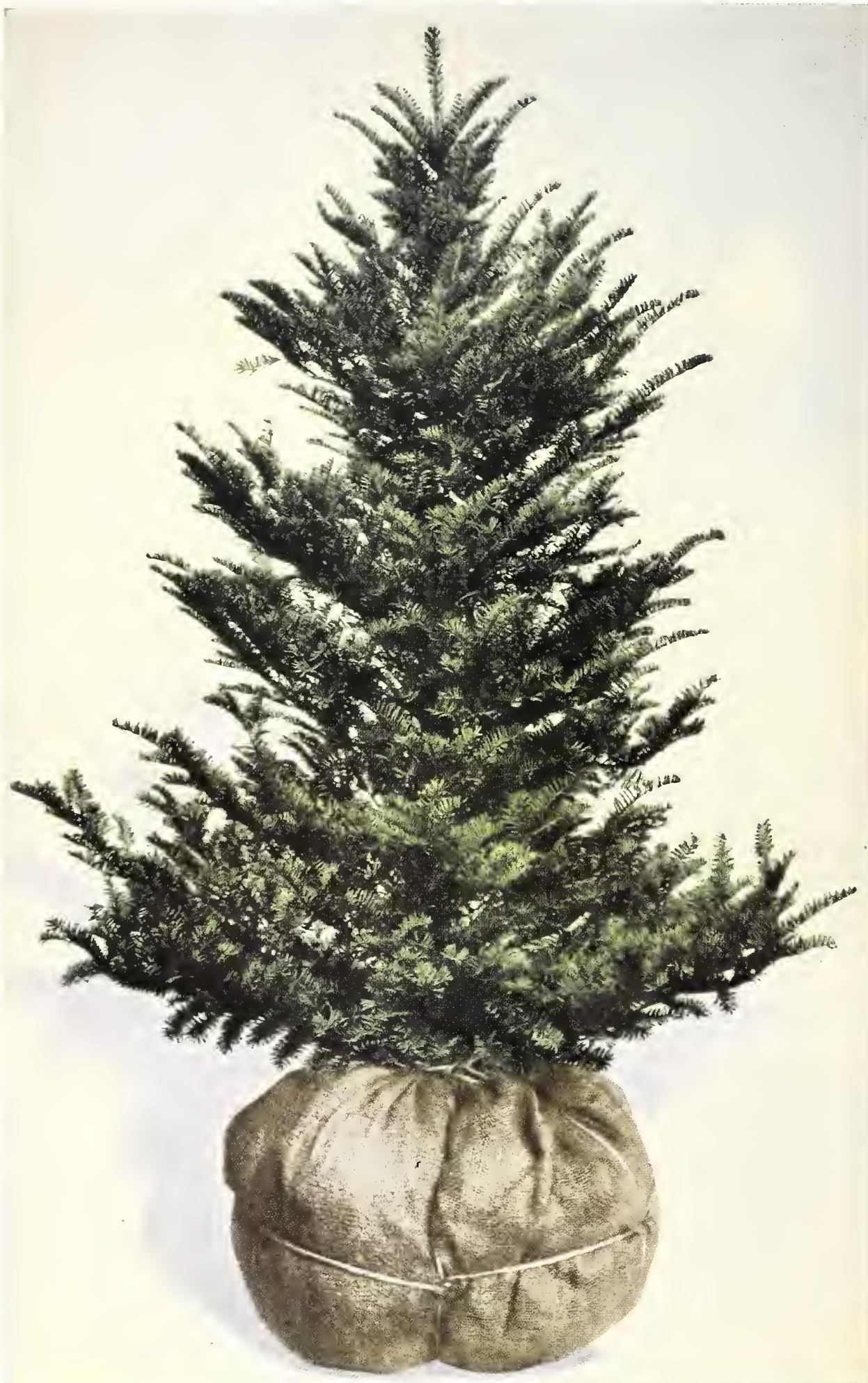

\section{-Janpanese Yew}

\section{(Taxus cuspidata)}

DHIs tree was originally brought to America from Japan by Dr. George Hall about 1862, the original trees being distributed by the Parsons Nursery at Flushing, Long Island. It has been established in America long enough now so that it has come to be looked upon as a tree of absolute depenability in our northern states.

From time immemorial it has been cultivated in Japan, where it is looked upon as a valuable tree in Japanese landscape art. The growth is close, compact and possesses a certain richness in appearance which marks it distinct from all other types of evergreens.

It has the typical, waxy, shiny, green leaves of Yews, and while it grows very slowly as compared to some types of evergreens, it is, for this reason, an especially desirable tree for foundation groups, formal gardens, rockeries, and similar positions where trees need to be kept within certain bounds.

The Japanese Yew which we offer is the upright, branched form which develops a leader, as shown in the pieture.

A great many of the Japanese Yews offered by nurserymen are spreading trees of irregular habit. This difference is due to the method of propagation. Trees produced from seed make superior tree-shaped specimens, while those grown from cuttings, - a somewhat more rapid process of propagation-produce less desirable trees.

The Yew produces its seeds in the form of a scarlet, cup-shaped berry. This method of reproduction classifies the Yew as a relic of the vegetation which existed on the earth ages ago. They are known as "drupe-fruited" trees. In Japan it is called the "Fir of the Goddess of Mercy." The importance of this tree for permanent plantings cannot be over-emphasized. In positions where trees must remain for many years with little attention, such trees are found to prove of great value. In locations such as cemetery lots, this tree is particularly to be recommended.

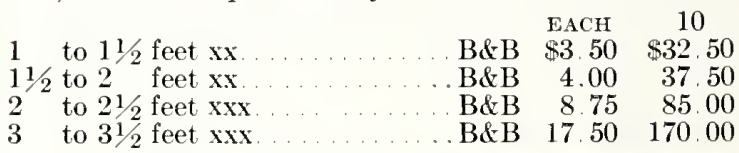

\section{The Ancient Yew}

$\mathrm{T}$ HE Yew is a very ancient tree which once covered large areas of the earth's surface. Geologists have found a "fossil forest" beneath the English Channel which gives evidence that the ancestors of the Yew tree flourished in bygone days, when the surface of the earth was much different than today.

"The Vine loves the hills and the Yew tree the north wind and the cold"-nearly 2,000 years ago Virgil was interested in the Yew and thus referred to it. It is one of the trees of perpetual youth.

Tithin the life of one Yew, empires rise and fall. A span of 3,000 years is credited to one Methuselah of the Yews which was some years ago eut down in England.

Five of the same variety and size at the $10 \mathrm{rate}$. Each $x$ indicates one transplanting. B\&B Bignifies balled and burlapped.

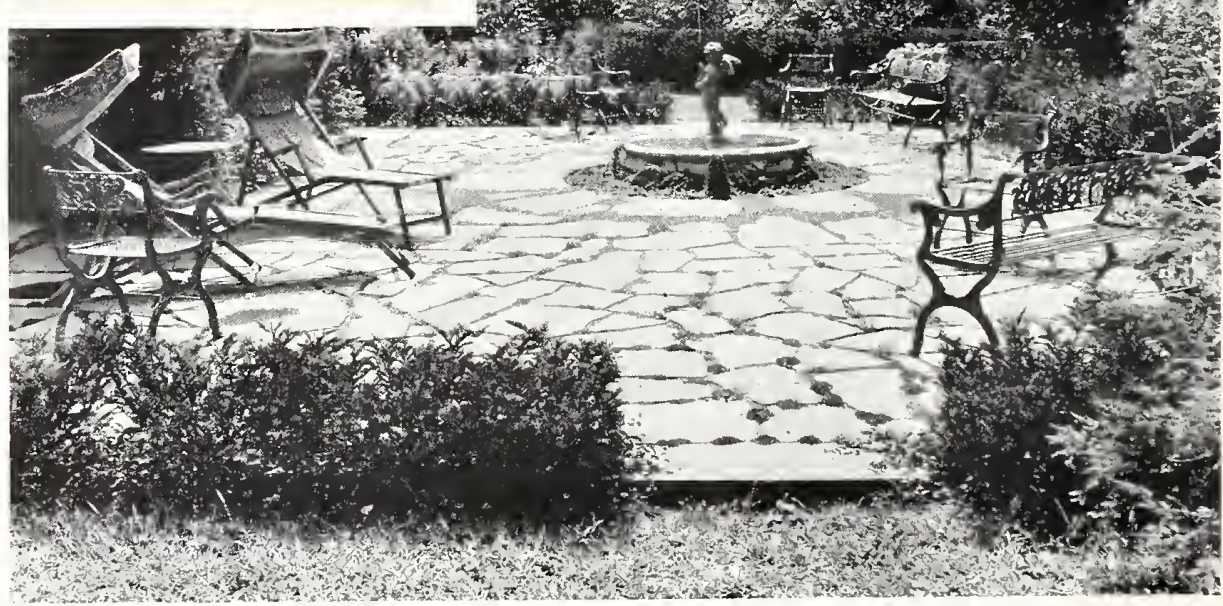

This stone terrace is most appropriately bordered with a low hedge of Japanese Yeu 

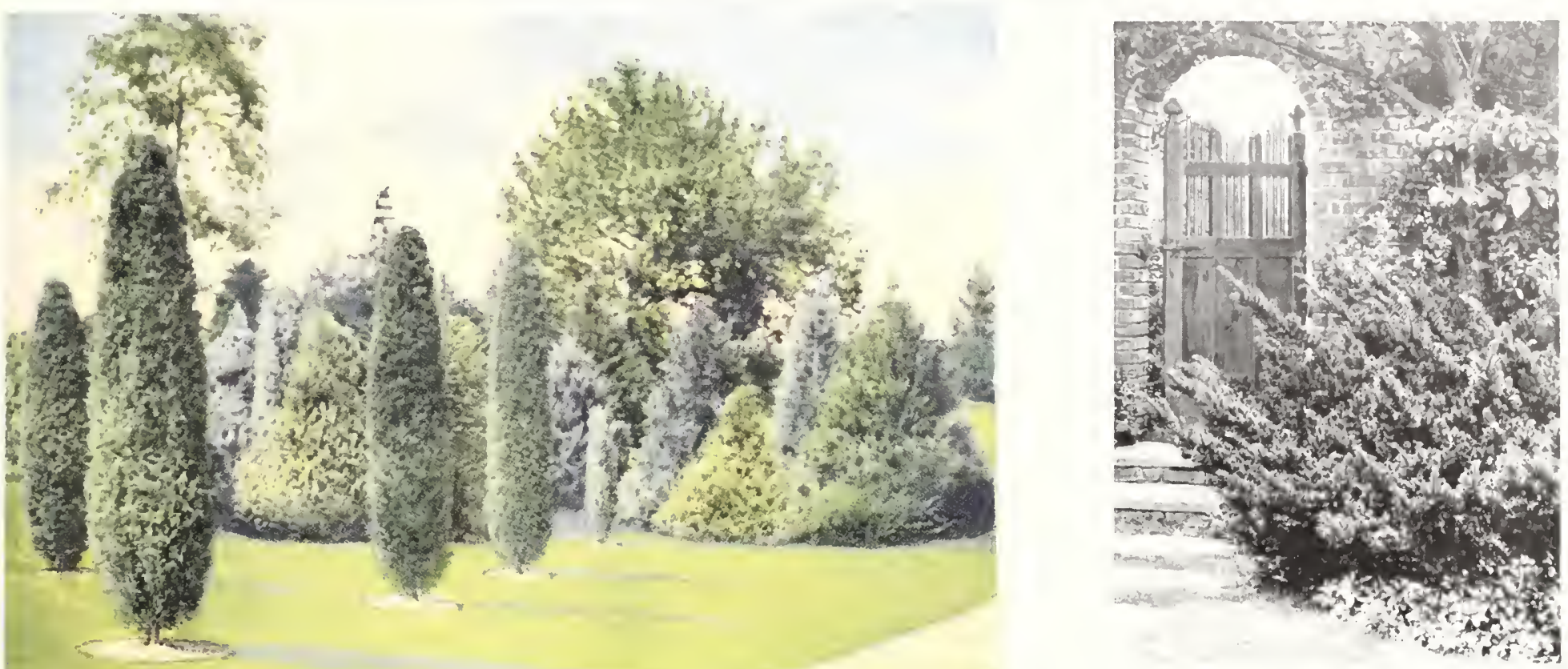

\section{Dwaref Dapanesce Mew}

Tarus cuspidala urum

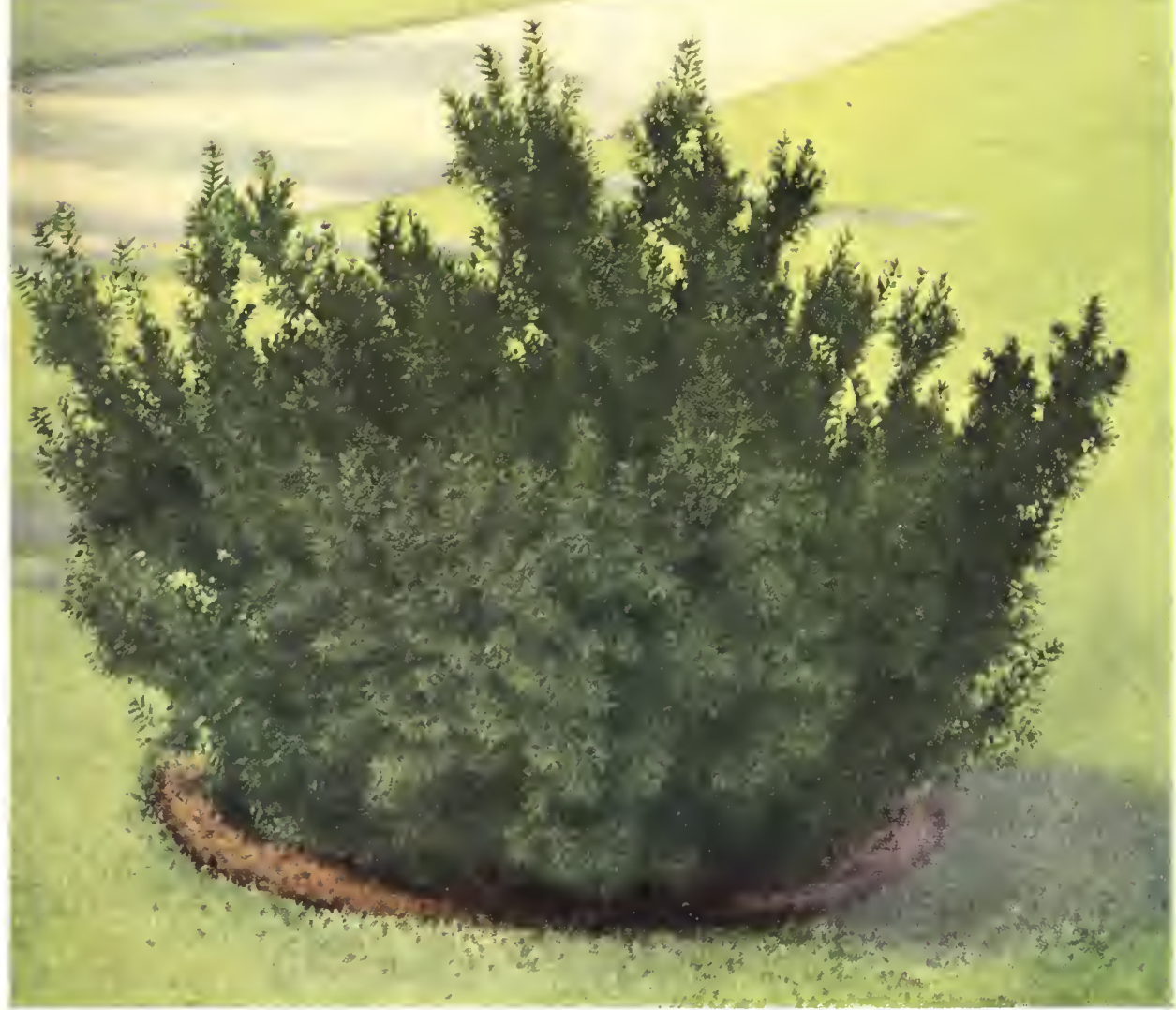

$\mathrm{T}$

It has a low, peculiar, irregular and pieturesine of old boxwookts and offer to planters in colder elimate wome of the charm which old boxworl trees pewsess

These trees have an added advantage of being ablo to thrive in dense shade. In this respert, they are superior to all other types of evergreenc, as they will actually thrive and make a thriftr growth when planted on the shatly wide of a building or under the shate of taller trees or shruls.

The tree shown in the colored picture ix at specinen growing on the mureery groumd, where it has been extallished for a number of years. I'ltimately, plant may reach three feret or more in height and three fert (w more in wilth. loy trimming, trees may be kept small wo they may be used in elose cuarter.

The branches are corered with little bunches of blackish-yreen foliage. The color is retained throughsut the season, which gives it an added arlvantage wer many forms of erergreens. The foliage is rery heary and of a waxy, shiny, green color

In many respects, this dwarf l'

Japanes forms of lew retain their mol throughcout the mot serere seasmin:

They are of extremely long life, and have that unn:ual
quality of growing uhd grace-

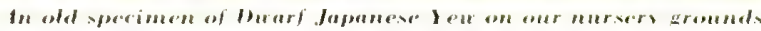

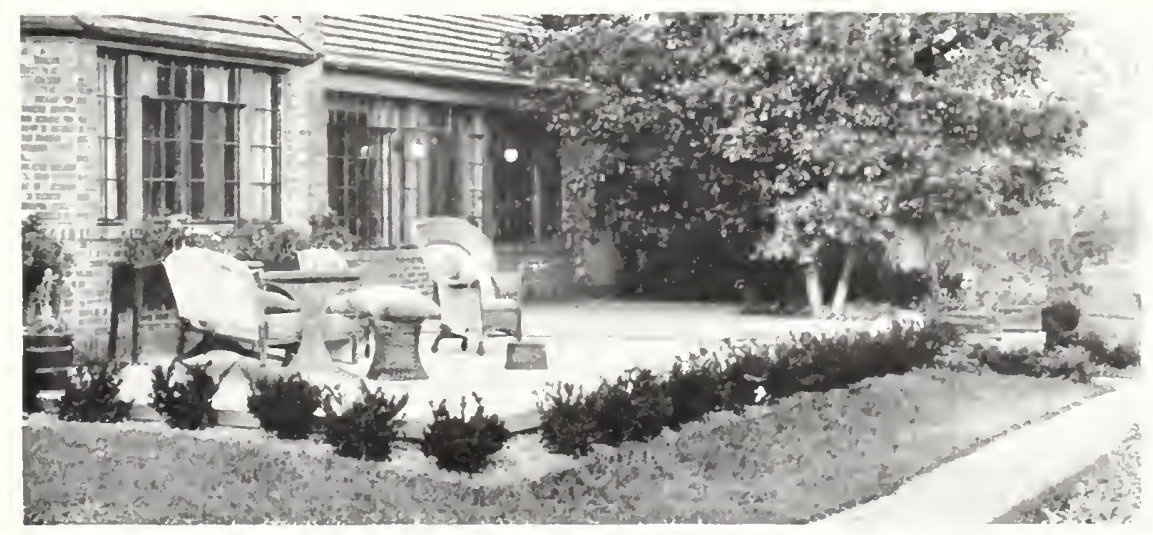

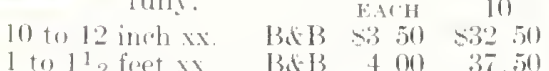

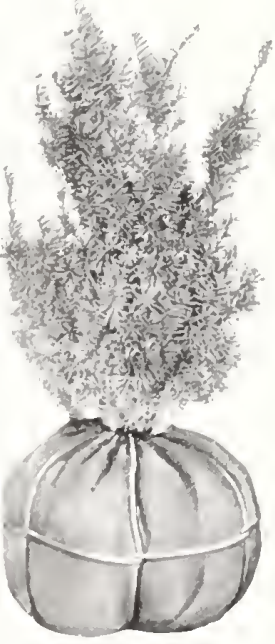

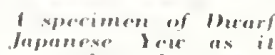

Vion ana know uha joy of a werll planta-d lomina

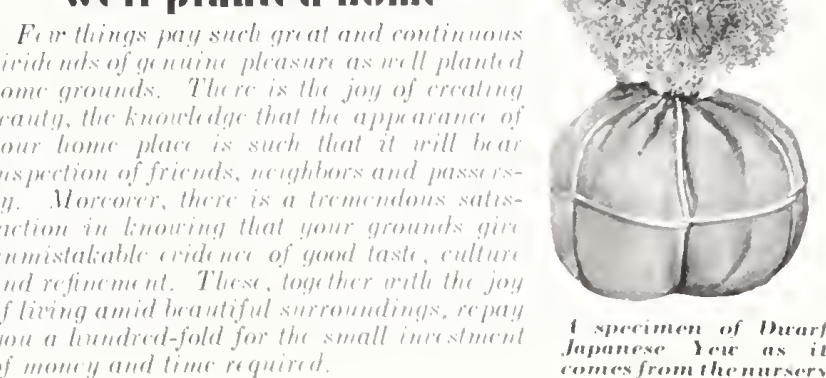




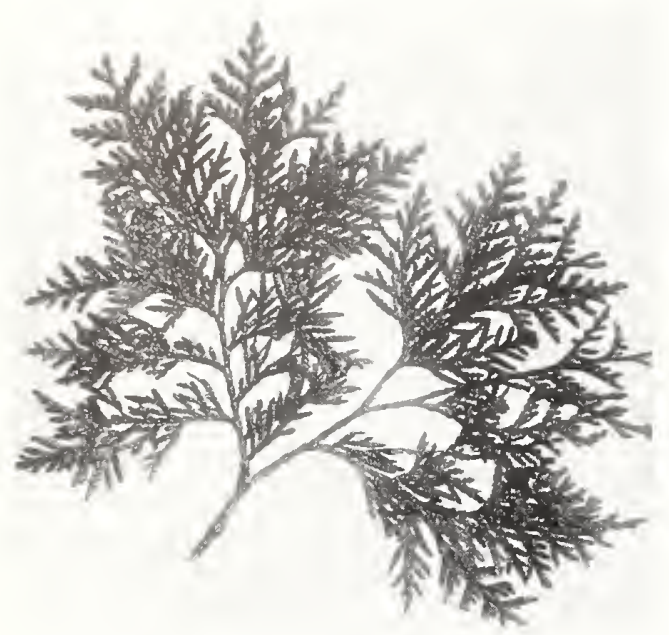

\section{American Aroborvitace}

\section{(Thuya occidentalis)}

How little I know of that Arborvitae
When I have heard only what seience can tell me.

$\mathrm{T}$

THE American Arborvitae is the mother tree from which upward of fifty distinct types have been developed, varying in color from deep green to bright golden and ranging in size from little dwarfs to tall, pyramidal specimens. The Arborvitae is very hardy and dependable in almost any situation. It likes a sunny location but will stand some shade. A moist location is preferred. Stands trimming well, and for this reason is widely used for hedge purposes. The rate of growth and ultimate height depend largely upon conditions. It usually grows bushy at the bottom and tapering toward the top.

Trees of this genus are of ancient origin, representatives of Thuya occidentalis having existed throughout the northern hemisphere in early periods of the earth's history. Its introduction into American gardens took place at the beginning of landscape development in America. It was probably the first American coniferous tree cultivated in Great Britain, having been introduced prior to 1597 , in which year it was mentioned by Gerrard in his "Historie of Plants."

The foliage is flat, arranged in sprays of lacy dark green, pungent scale-like leaves.

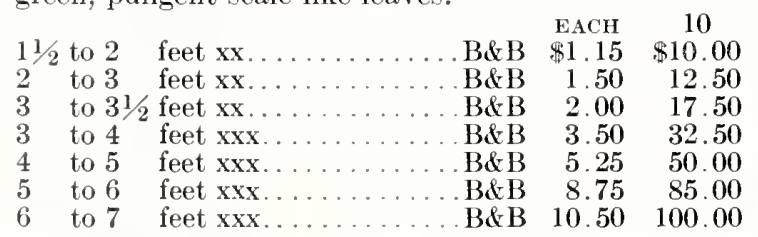

Five of the same variety and size at the 10 rate. Each $x$ indicates one transplanting. BAB signifies balled and burlapped.

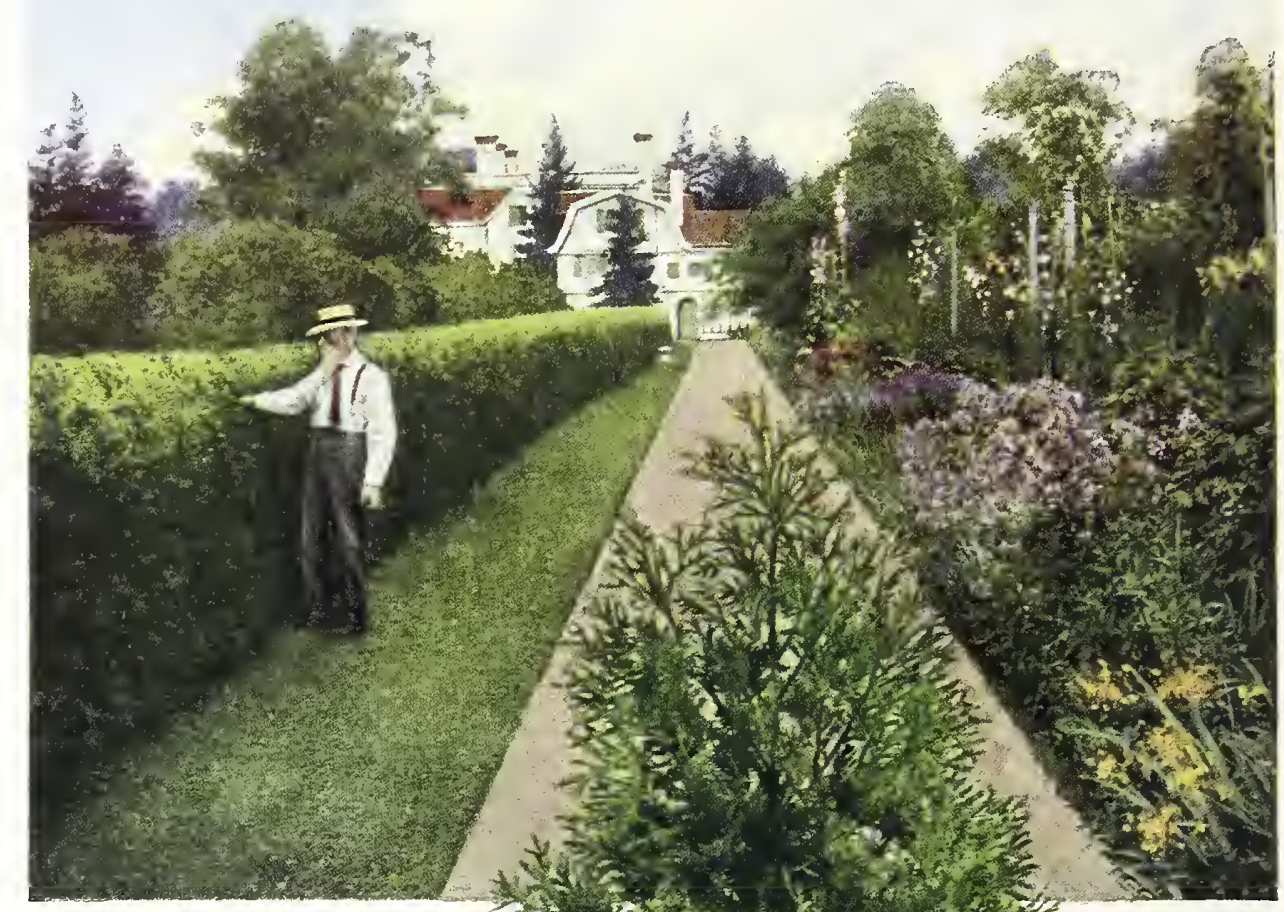

AMERICAN ARBOR VITAE

The leading Evergreen hedge plant. Equally

attractive as a specimen

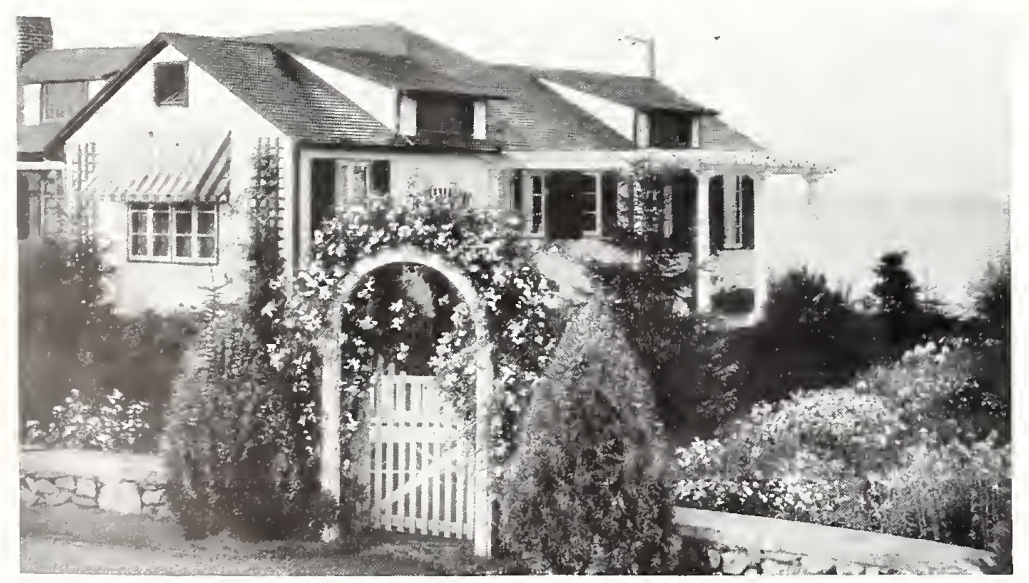

Through the courtesy of $E_{0} \boldsymbol{F}$. Ulodgson Company of Boston, Massachusetts, we show this little house by the sea-shore appropriately planted with Arbortitae

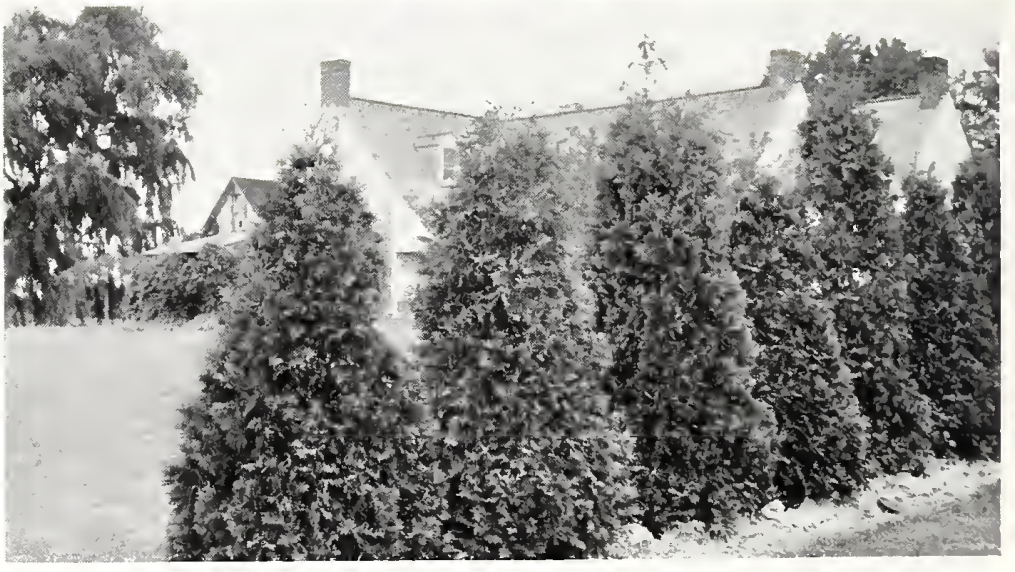

As an informal hedge, sercen or border. American Arbor 


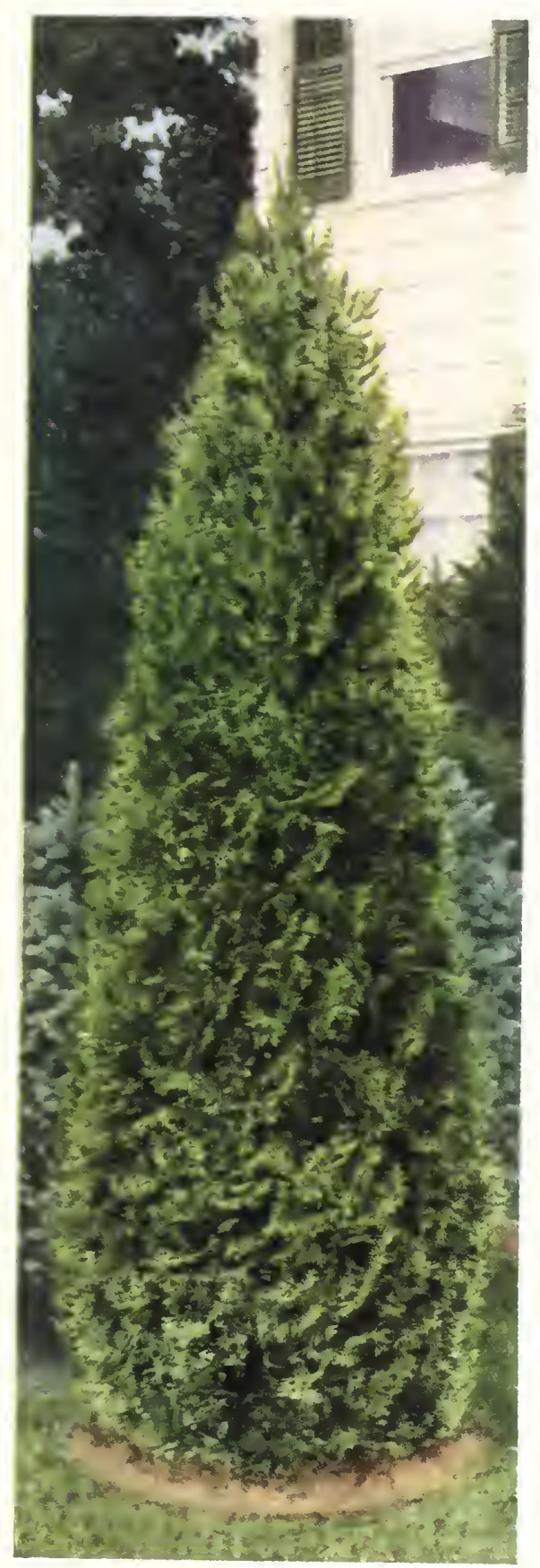

A splendid example of Hill Pramidal trborritae

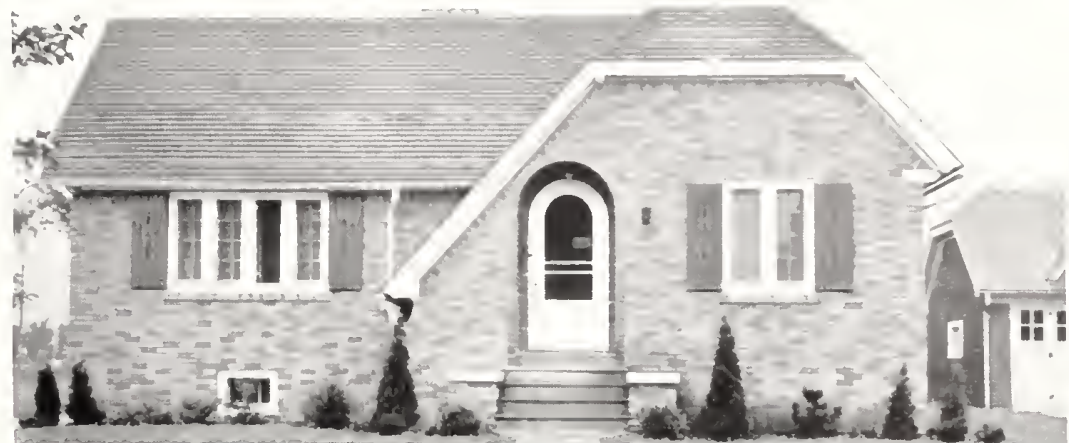

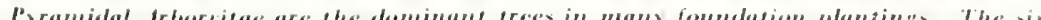

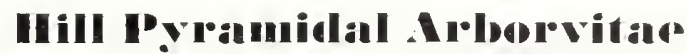

(Thura orcidentulis pyramidalis)

The Hill Pyramidal Arborvitae has become an exiential part of almo-t all landscape plantings in the middle west. It furnishes the necosary talk narrow effeets for foundation plantings, is a great favorite for entranees and is often seen in formal gardens or for markers in gardens of various kind-

On aceount of its rapid growth, its bright green eolor, its shapely even pyramidal habit, and eave of being trimmed, it rank- among the first half dozen leading Exergreens in this section of the eountry, By produeing it by the hundreds of thousands we are able to offer our enstomers a wile range of sizes at remarkably low prices.

The improved Hill Pyramidal Arburvitae is the result of many years expert attention. They are all grown from a few original, selected treepicked out by the late D. Hill. He realized that there was a great variation in eharacteristies among the Pyramiulal Arborvitae and then decided to pick out a type of uniform good qualities and orow nothing else. Hill l'yramidal trborvitae has gained a nation wide reputation on aceonnt of their superior merit.

Pietures on this page give an idea of the development of thitree. It grows narrow, trees twenty feet high, seldom smreading over two feet in diameter. Inder favorable conditions trese reach considerable height but may be freely eut and trimmed and thereby kept within any bound necesary.

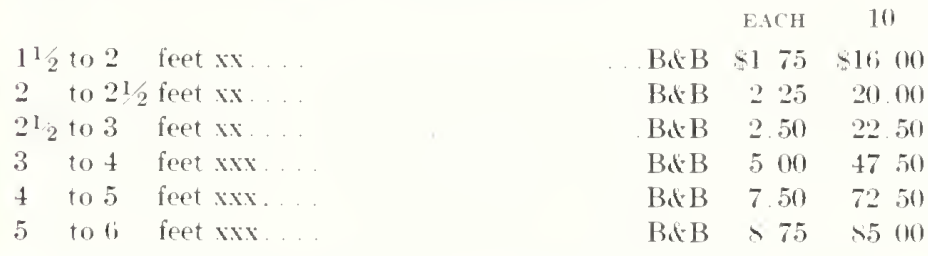

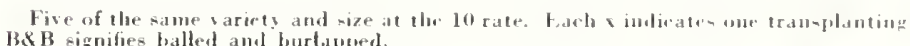

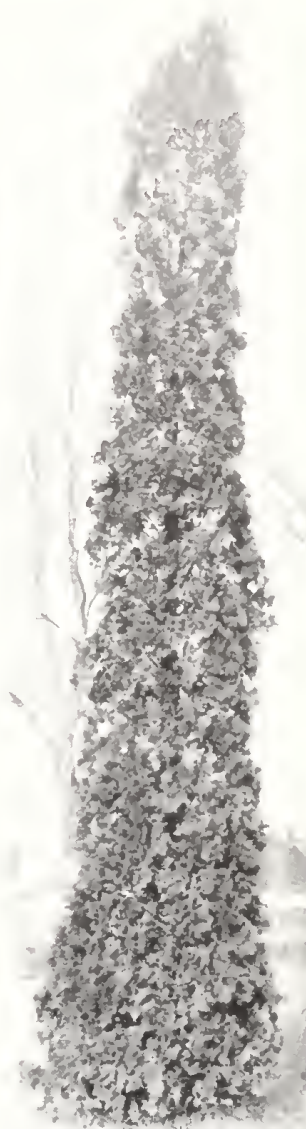

This eree is atower the ex-

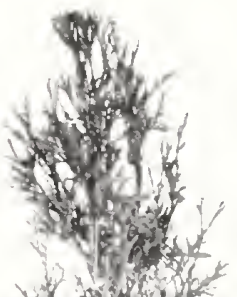

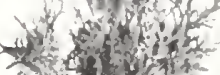
A) 1 (a) ind Int in 1 . 3) 1,13820 rind

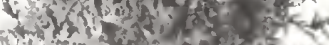

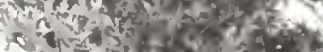

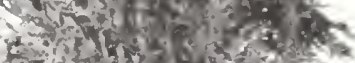

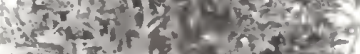

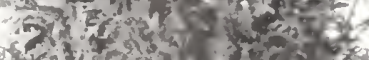

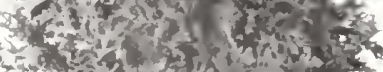
$-7 x=2 x$

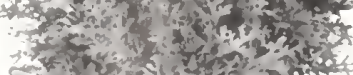

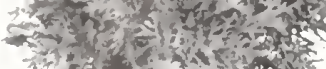
y $7 x+3+1+4$

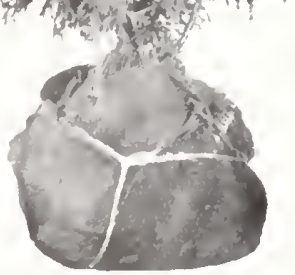




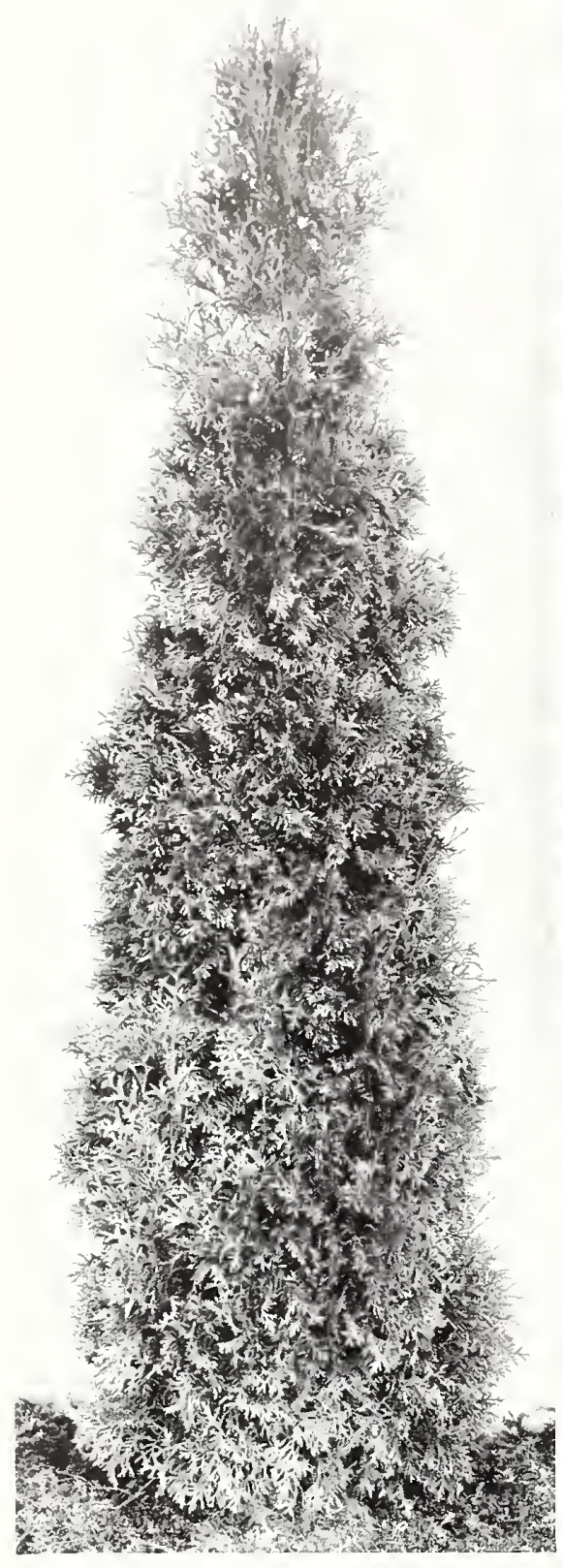

Douglas lyramidal Arboritae

\section{Douglas IPyranmidal Arlonrvitare}

Thuya occidentalis donglasi pyramidalis)

A

COMPACT form with crowded fern-like branchlets, introduced by Robert Douglas. The branchlet tips are cockscomb-like. Foliage is dark green with lighter tips. Fine pyramidal habit. Reaches a height of 12 to 15 feet of slim narrow form.

The Amold Arboretum says: "As a garden plant, the most valuable of them all (Arborvitae types) is perhaps the tall, slender pyramid raised many years ago by Robert Douglas and generally known as Douglas Pyramidal Arborvitae."

This appears to be one of the best substitutes in northern gardens for the Pyramid Italian Cypres.

$11 / 2$ to 2 feet $\mathrm{xx} . .$. B\&B $\begin{array}{rc}\text { EACH } & 10 \\ \$ 2.00 & \$ 17.50\end{array}$

Purehase your Evergreens from true Evergreen Specialists. We are the only extensive growers of Evergreens exelusively, in America. This one
line has our undivided time and attention, devotion and study. We are thus Evergreen spe.

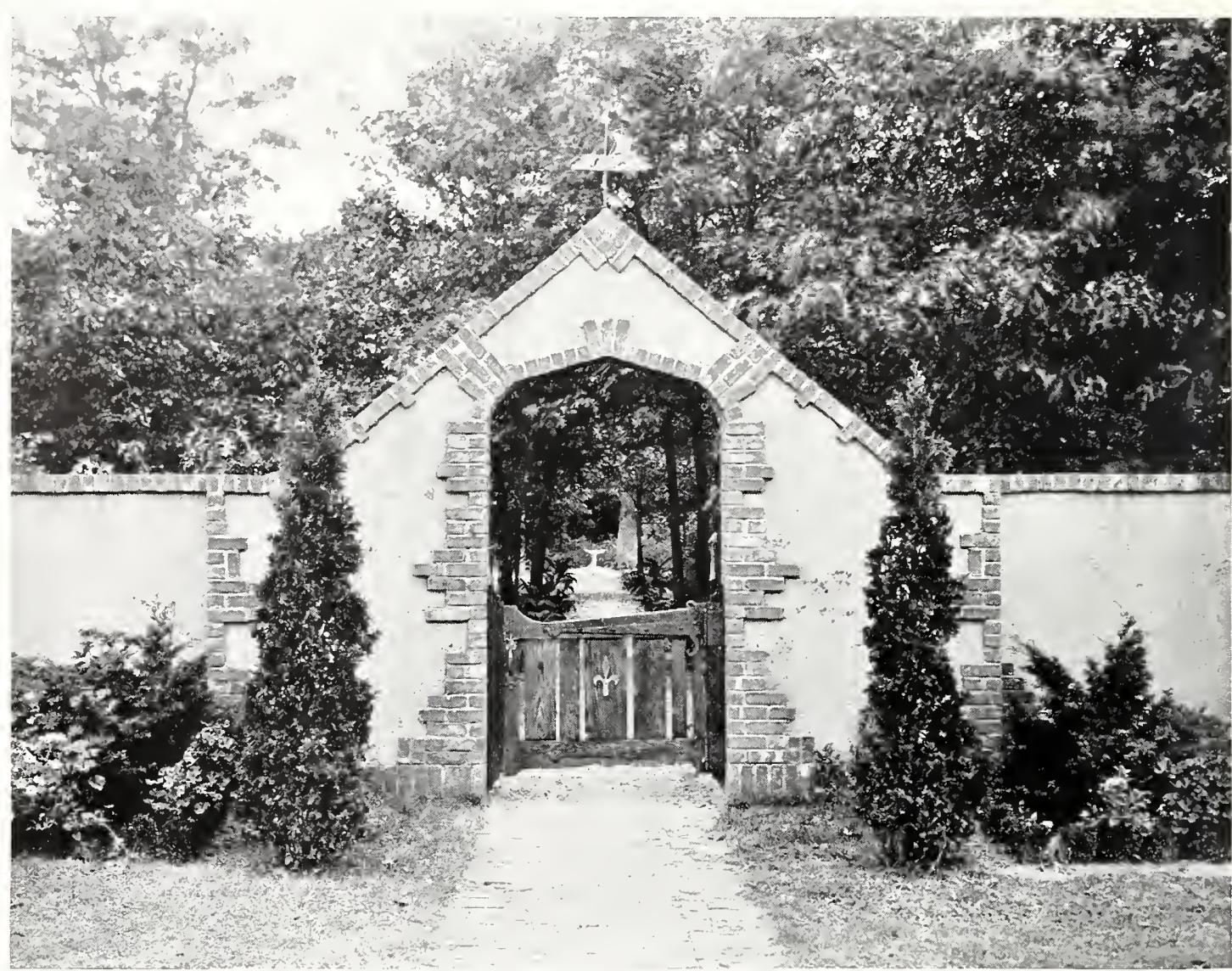

The tall spire-like forms of the Douglas tyramidal frborvitae are well chosen for framing this garden gateuay

\section{Douglas Golden Arborvitae}

Thuya occidentalis donglasi aurea)

T'T forms a broad, bushy, pyramid, very similar in outline to a good type of the regular American Arborvitae. The foliage is decidedly golden, very bright in the Spring and keeping its color well. The bright golden color is best displayed when planting this variety with a background of darker shades of green. It grows in any ordinary good soil and does especially well in moist cool locations.

Among the golden forms, the Douglas Golden Arborvitae is well known and widely used. It is a form originated by Robert Douglas of the old Douglas Nurseries at Waukegan, Illimois.

No one wants an entire planting of yellow-foliaged trees, but one or two to add a note of contrast among the green of other trees is always pleasing. In habit, this tree closely resembles the American Arborvitae, from which it originated.

$11 / 2$ to 2 feet $\mathrm{xx} \ldots$... B\&B $\$ 2.00 \quad \$ 17.50$ 2 to 3 feet $x x$... B\&B $2.50 \quad 22.50$ 21/ to 3 feet $x \times$ B\&B $3.50 \quad 32.50$ 3 to $31 / 2$ feet $\mathrm{xxx}$.... B\&B $4.00 \quad 3750$ $31 / 2$ to 4 feet $\mathrm{xx}$.... B\&B $4.50 \quad 42.50$ Five of the same variety and size at the 10 rate. Eaeh $x$ indicated.
burlapped.

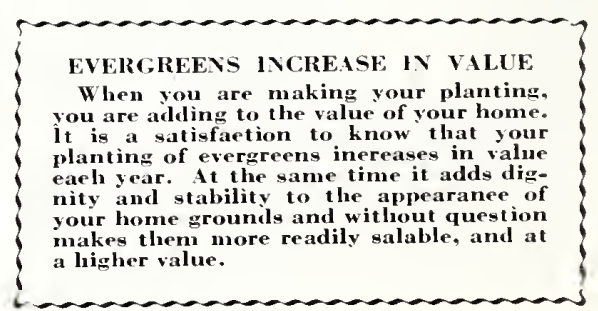




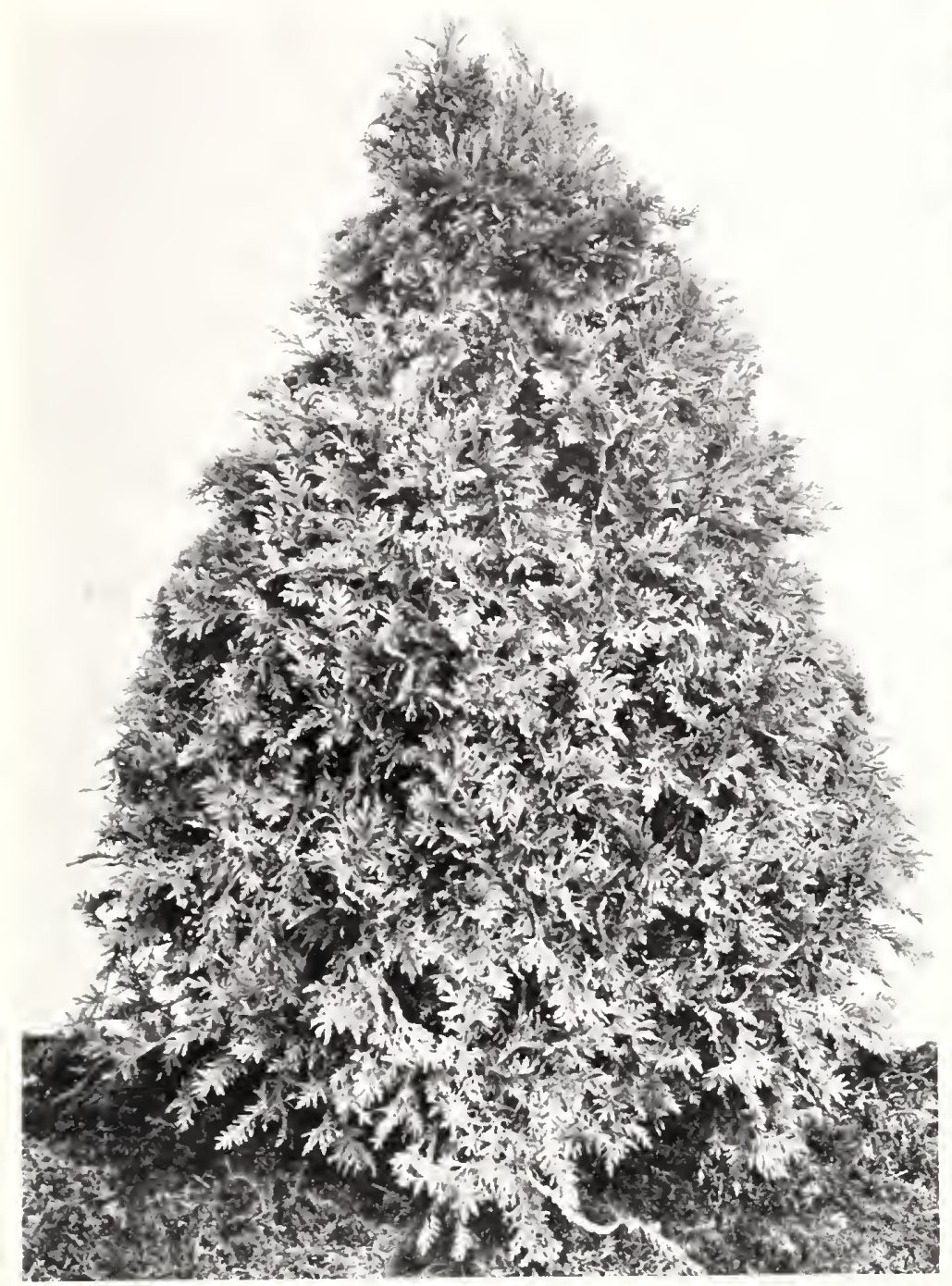

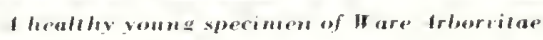

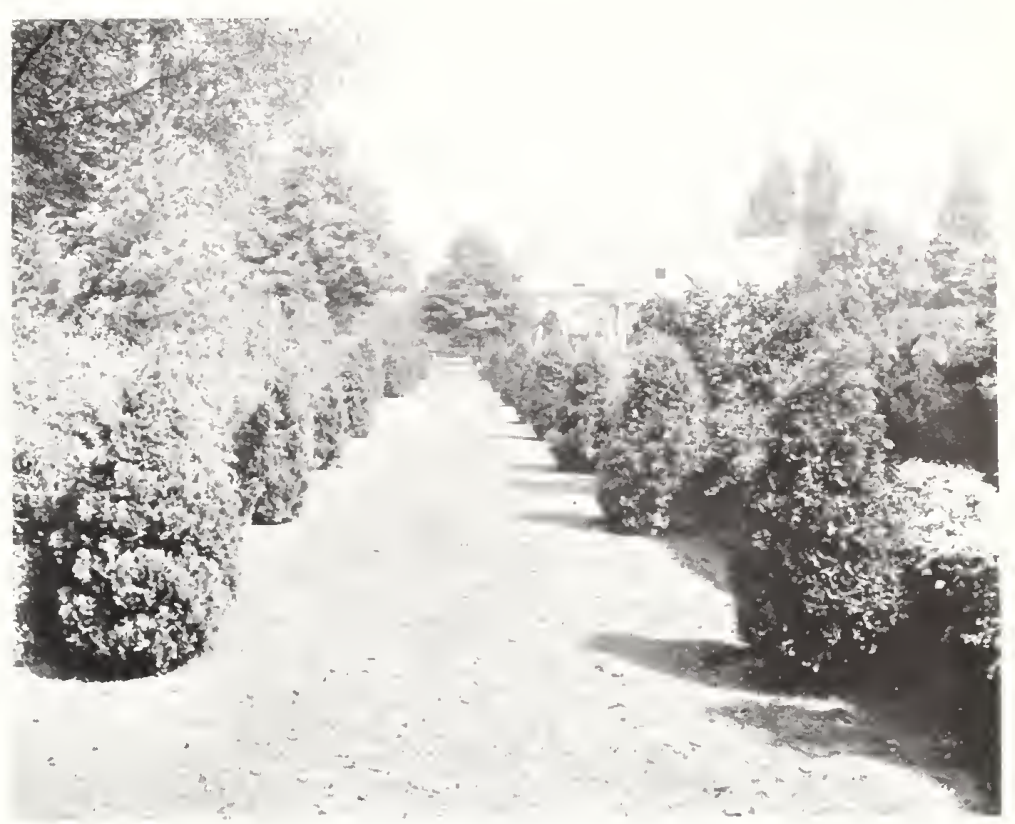

\section{Warpo Ir-bonvilate}

\author{
(Sibrian)
}

Thuja occidentalis 1 areana

$\mathrm{T}$ HE name siberian has been given to it becaune of its rugged emstitution. A symmetrieal, compact grower, rery long livest. in outline and covered with dark green foliage which is somewhat different from the Ameriean Arborvitae, being much heavier and deeply crested. The branches are short and stiff. It is mueh used for foundation planting and frequently for hedge

It has a great adrantage not posesond hy most other varietire of the arborvitae family. It keeps a good green winter color.

1. D. Webster, in his book on "(oniforous Evergreens" decribus it: "Of dence neat habit and remarkable for the deep green of the folinge. It is rely desirable for ornamental planting. being regular of growth, of deep foliage tint, and with the branehlets chustered and compact, at the ends of the branches."

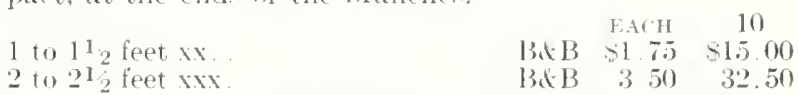

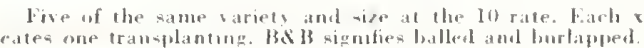

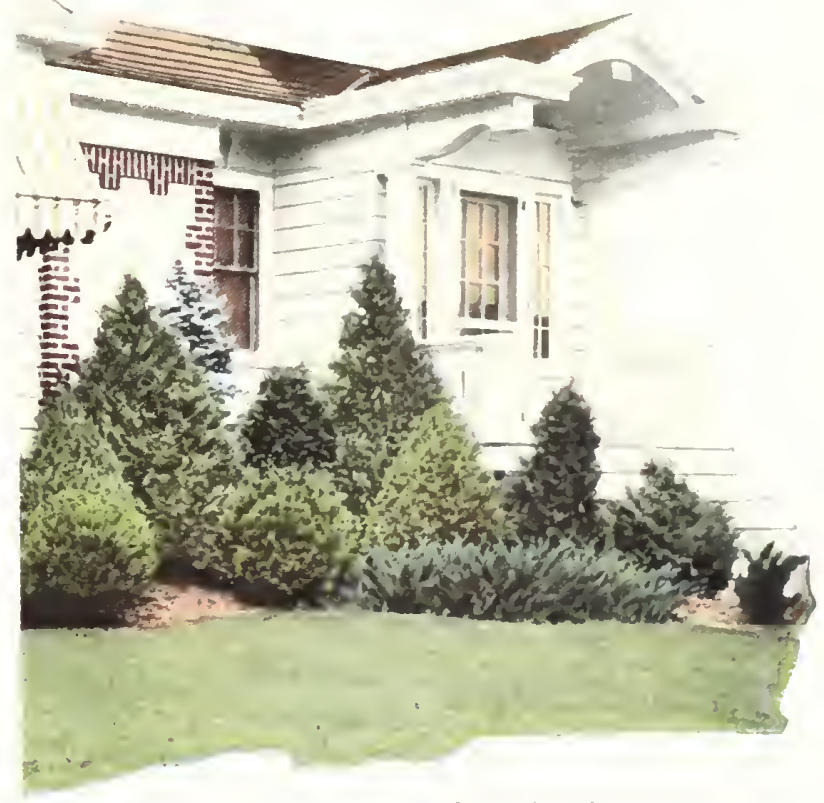




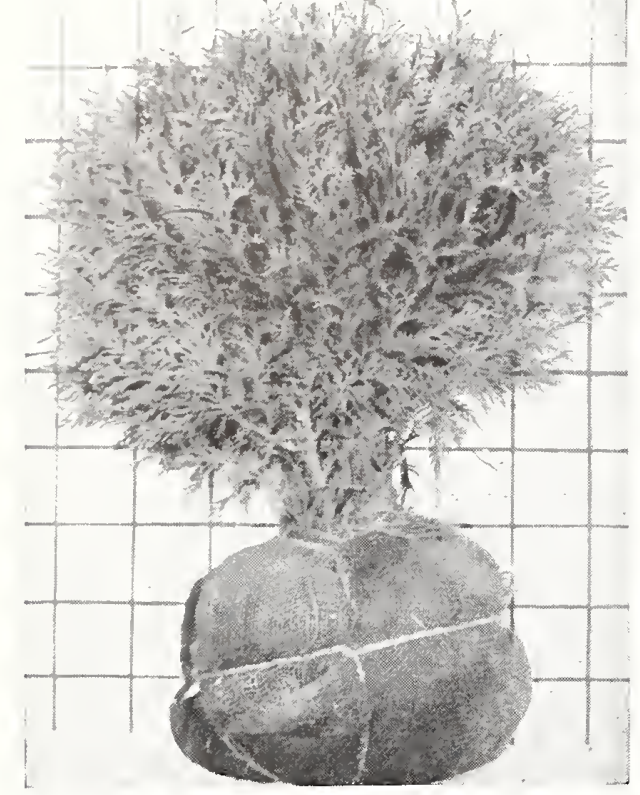

Even in the 10 to 12 inch grade pictured here, the

\section{Wodedwared Arborvitane}

(Thuya occidentalis wooduardi)

$\mathrm{T}$

HERE are, no doubt, at least twenty-five varieties of so called Globe Arborvitaes globe forms of all sorts in all kinds of soil and planting conditions and can recommend the Woodward to our customers as giving the best atisfaction for general landscape use.

It maintains the natural globe shape without trimming, and under good conditions will reach three feet in height and diameter. It is especially fine for low borders, for formal uses, for tubs, urns or foundation groups.

The variety was originated and introduced by Mr.Manning, proprietor of the Reading Nurseries, Reading, Massachusetts, and named after his son Woodward Manning. A few plants presented to Mr. D. Hill by the introducer many years ago

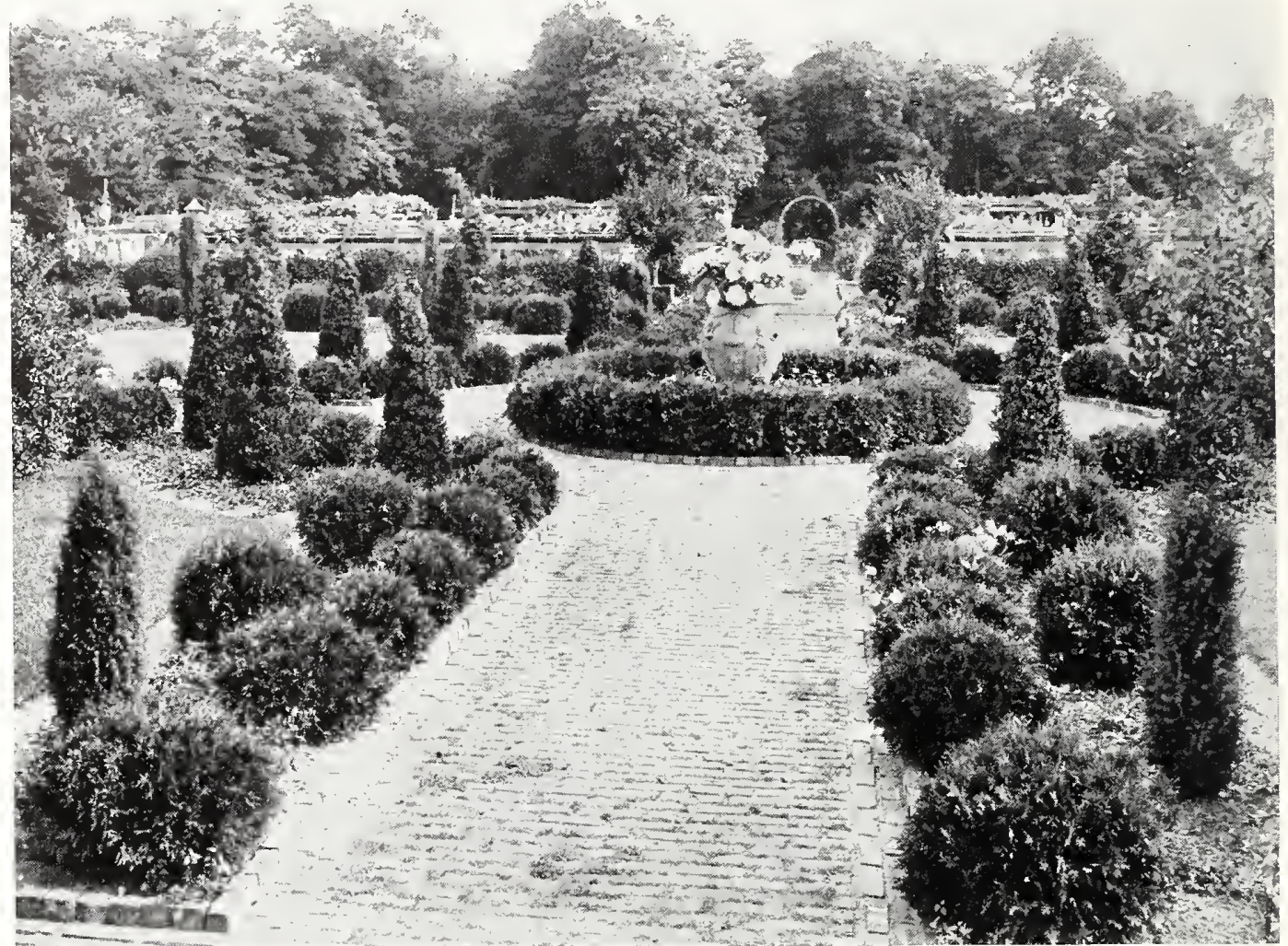
This format garden makes good use of Wooduard Arbor
vitae. Its regular, even form is well suited to gardens of

forms the basis of our stock. We can therefore, justly say that our stock is the original true strain.

The propagation of Woodward Arborvitae has been carried on under the favorable conditions that surround the production of all Hill Evergreens, and which tend to make Hill Evergreens standard among all producers.

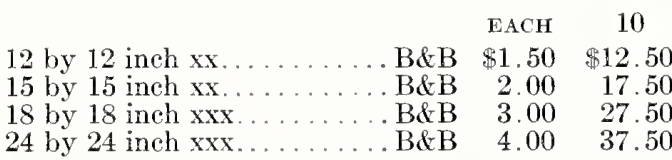

Five of the same variety and size at the 10 rate. Each indicates one transplanting. B\&B signifies balled and bur
lapped.

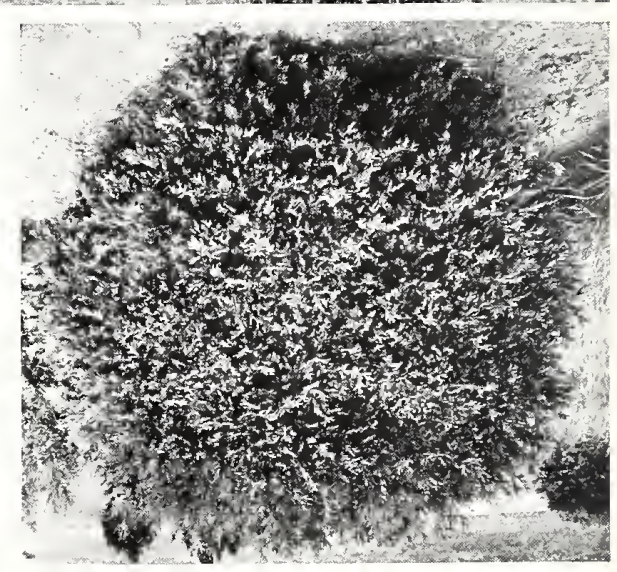

An old tree of Wooduard Arborvitae shouing its tree is thred

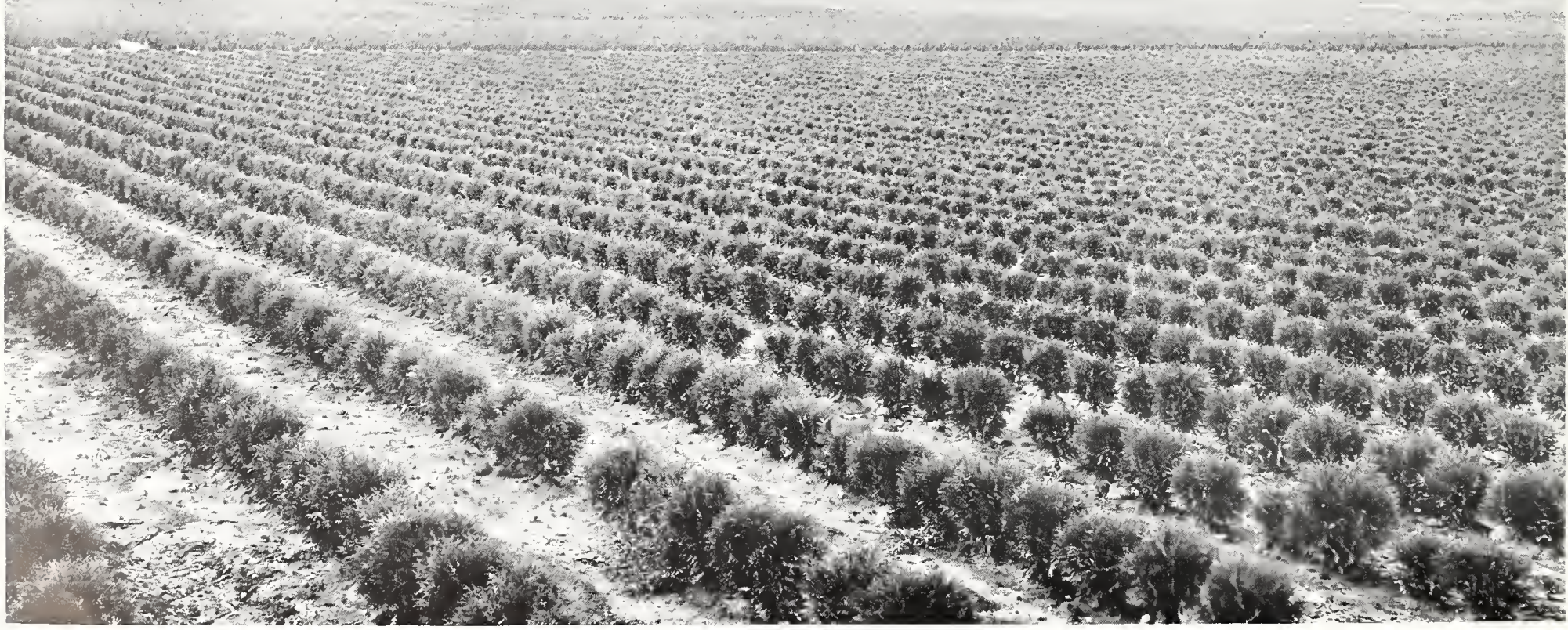

Woodward Arborvitae has been the leading ball shaped Evergreen in the Hill Nursery for many years. This field of 30,000 trees will make choice specimens after 


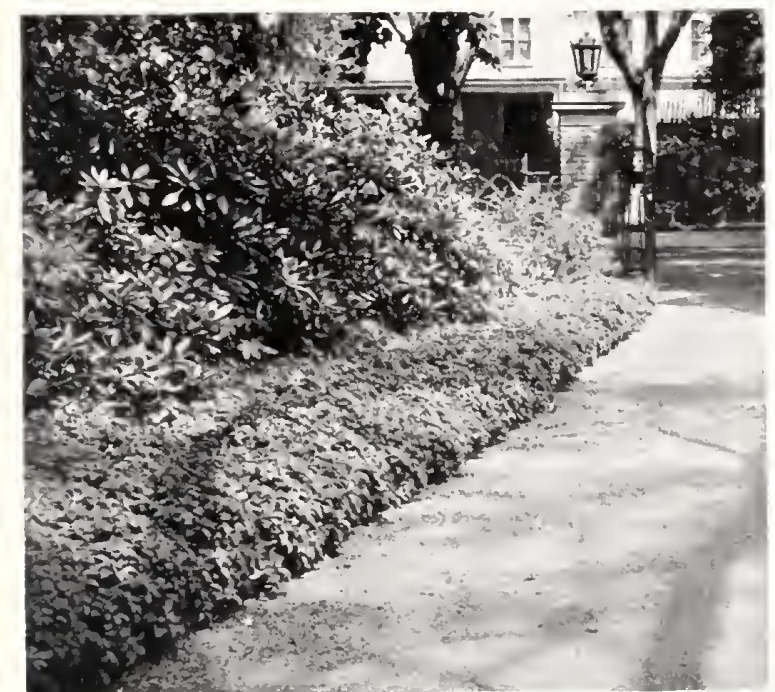

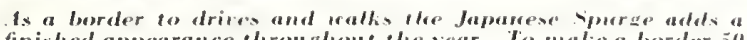
feet long, only goo plants irould be requeded

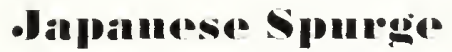

(Paclessamilrn Terminulis)

I REMIRKIBLE EVERGREEX I'LANT OF II INY ISES

WHAT IS IT"

A BROAD-LEAFLD EYER(IREEN plant growing 6 to $\mathrm{s}$ inches high and forming a ekse mat-like growth, formed by planting several plant s close together.

HOW TO LSE IT

When used as an underplanting, it gives finish to your plantings of shrubs, trees and flowers, by envering the bare soil. It helpo Evergreens to eonserve molsture when planted beneath them, furnishing more of a natural forest eondition. It is good for growing on bankand terraces, its fibrous roots and ereeping -tolons help to hold the soil. It is an excellent plant for a low border along drives and walks. It is an ideal plant for window boxes both winter and summer. It is just the thing for hare spots under trees where grass will not grow. It makes a leautiful and perpetual rovering for graves in cemetery planting. It thrives in city yards under smoky conditions. Rulbs may be planted in it. It is also an interesting plant in a roek garden. It is perfectly harly under all conditions, stands serere freezing without discoloring. It haw a bright green, attractive foliage.

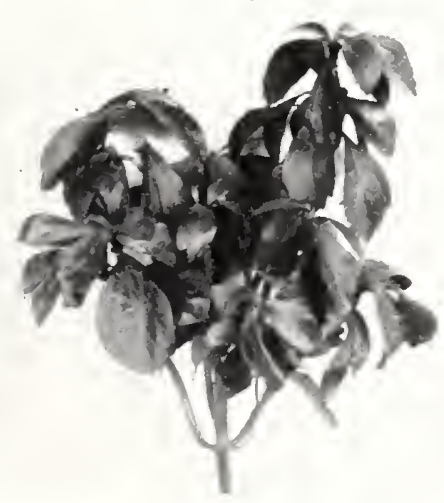

This closente detail of the foliage of the

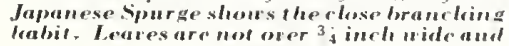

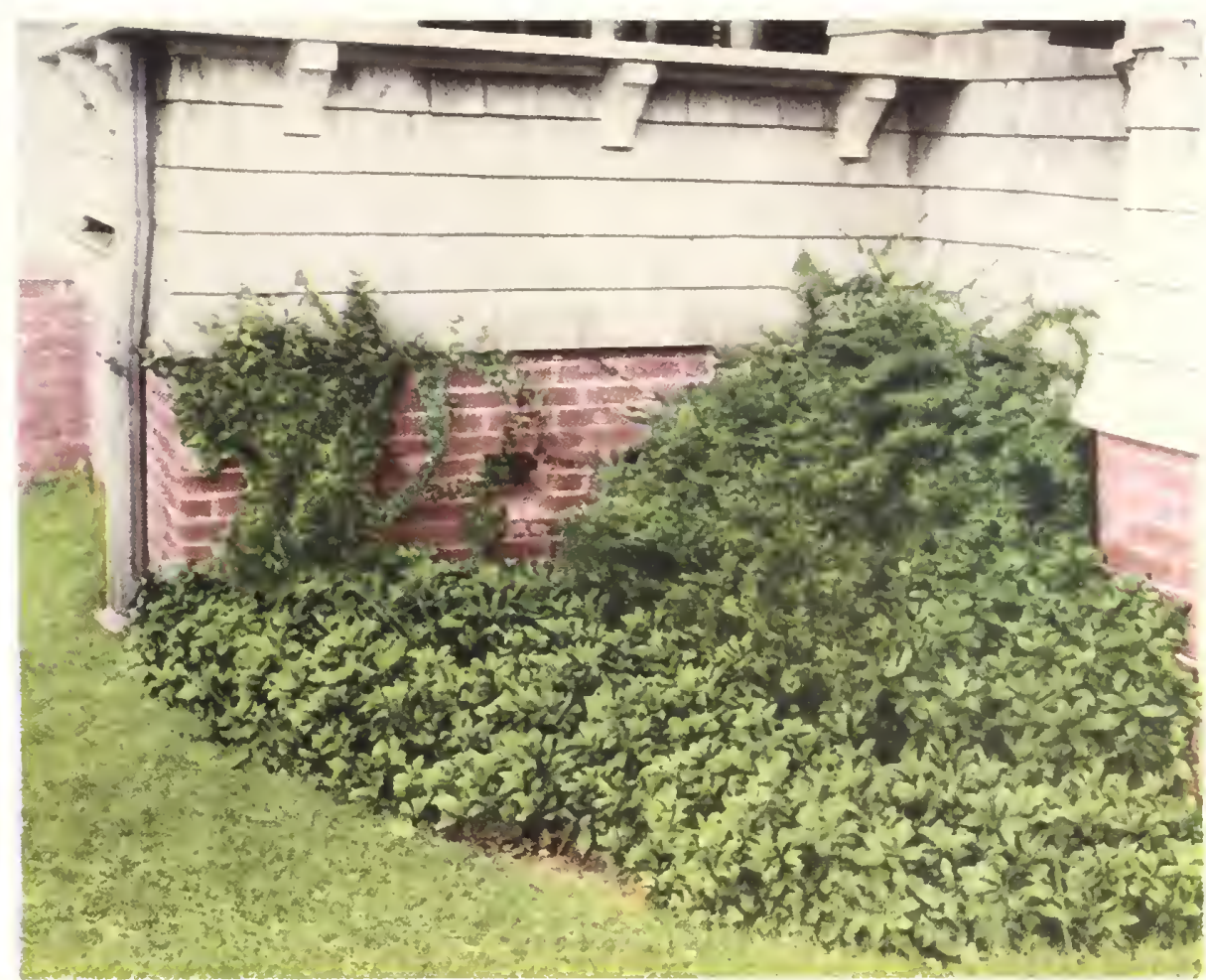

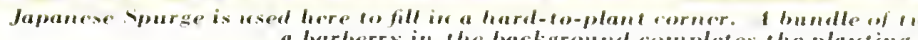

H(BI TO PLIYT

To be efferetive, Japanese sinnge must be thickly planted. A secret of making a watisfactory growth, where the plant is in the slun, is to plant thiek enough so that the sunshine does not get at the root sritom. It will grow in full sun if the plant- are set close together. It makes its mont lusuriant growth in dense or partial thade.

set five or six plantw in each square foot of grouncl area or plant four or five inehes apart as a border. Even cluier plinting than this will do no harm. CLLTURAL DIRECTIONS

The Japanese spurge requires no attention but improses in luxuriant growth with age. Plantings fifteen yoars old are still in perfect condition. A light application of finely pulverized compost conld be applied every two rears with beneficial results.

It does not have any noticeable flowers, but is favored for

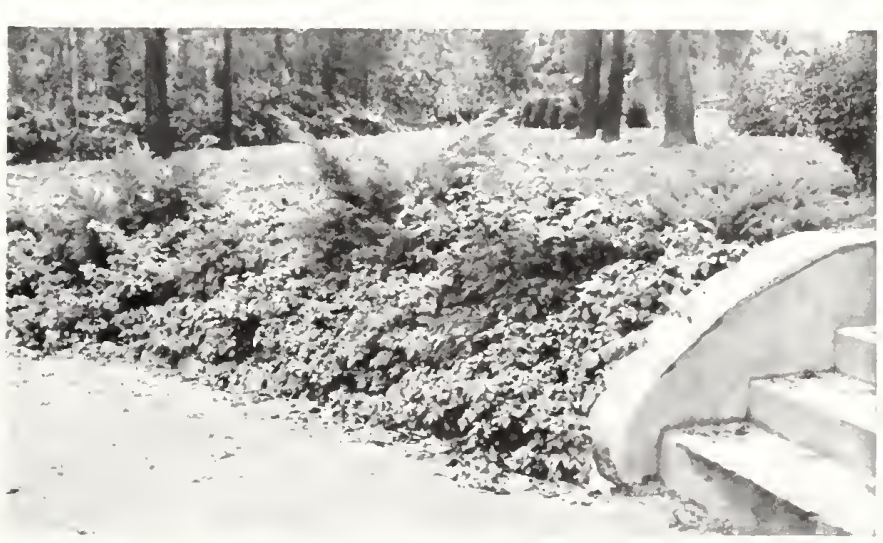
trellises or walls. lose it in various ways as hown in pictures on this page. It is put up in bundles of 25 and packerl in nuse for shipment by Parcel Pont or Expres.

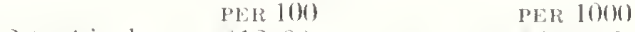

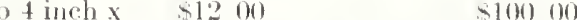
25,50 or 75 at 100 rate. 500 at 1,000 rilte. 


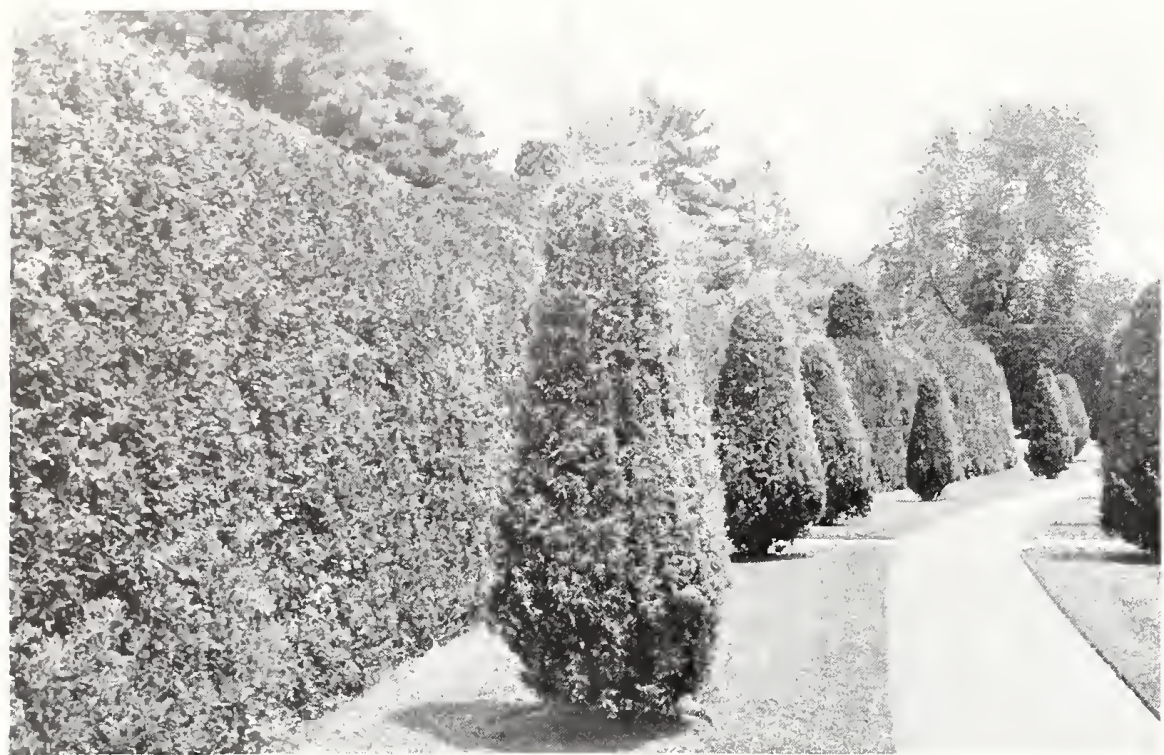

\section{Evergireen Hedges}

Best for Year Round Service

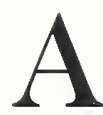
HEDGE should be as attractive and as serviceable in the winter months as in the summer months. Evergreens are the only plants which are permanently attractive and useful. In Europe, almost every garden has an Evergreen hedge of some kind. Planters in America are, more and more, learning to surround their gardens and their property with attractive Evergreen hedges.

Hedges may be of almost any shape and size and may serve many difierent purposes. Arborvitae is the most widely used of Evergreen hedge plants because it can be so easily trimmed into various sizes and shapes. It may be used as a tall screen or hedge, as in picture above, or a low hedge two or three feet high, as in the picture at the right and top of the page. It may also be kept extremely small and used as an edging or border for flower beds.

There are other trees ideal for hedge purposes which we also offer in addition to the Arborvitae. Hemlocks, Yews, and Spruces are all suitable hedge materials.

\section{HOW TO PLANT HEDGES}

Evergreens are set from twelve to eighteen inches a part if set in a single row. Where space permits they may be set in two rows spacing the trees alternately, setting the rows about one foot apart. The plants in one row should come opposite the open spaces of the other row.

Hedges should be planted at least three or four feet from sidewalks or property lines to

\section{PRICES}

AMERICAN ARBORVITAE

\begin{abstract}
10 to 12 inches $\mathrm{xx}$
12 to 18 inches $x x$

18 to 24 inches $\mathrm{xx}$

2 to 3 feet $x x^{\circ}$
\end{abstract}

10 to 12 inches $\mathrm{xx}$

\section{WHITE SPRLCE}

allow for future development and to avoid crowding.

American Arborvitae should make a very presentable hedge after five years. Of course it is attractive immediately after setting out but before it can be trimmed into a compact formal growth, about three years time is necessary. When once established, hedges last indefinitely.

The trees can be set out either in the Fall during late September or October, or in the Spring as soon as the Spring shipping season opens. Before starting to plant, have a trench dug and ready. This should be at least two feet wide and eighteen to twenty-four inches deep. Let the bottom be filled with loose earth rounding in the center so as to permit a downward spread of the roots. The roots of Evergreens should never be exposed to the sun and wind, or allowed to get dry. Keep the roots damp until the trees are in the ground. As soon as the hedge is planted water thoroughly and continue watering Spring planted trees all during the first summer.

\section{Suggestions for Pruning}

Hedge plants can be cut at once after planting, but the first trimming should not be too severe. Remove any stragghing and irregubroader than the base, sunlight do

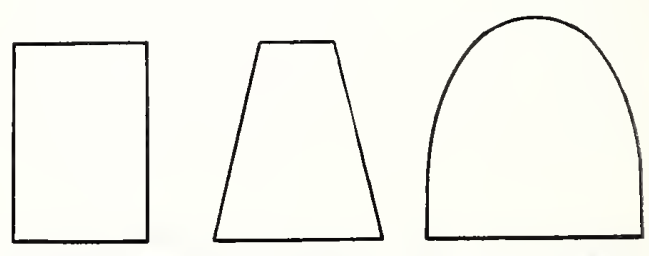

Sunlight reaches the bottom branches of hedges trimged lite these, and they remain dense and health

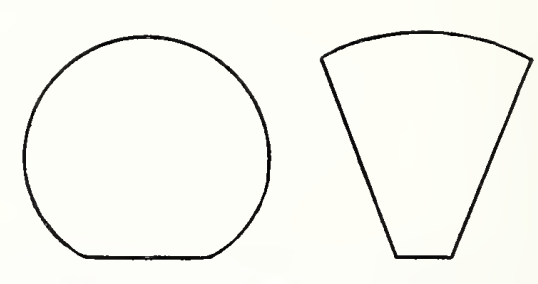

Becanse the tops of hedges, trimmed like these, are cut away are intended by nature as a protection for the buds which are to make next summer's growth.

lar branches and bring the individual trees into as nearly the same size as possible. The permanent shaping of the hedge will require a watchful eye and a careful hand. The (ime is four to five years, but gradually a solid best hedge. Trim only once a year and always before new growth appears, the latter part of May or early June.

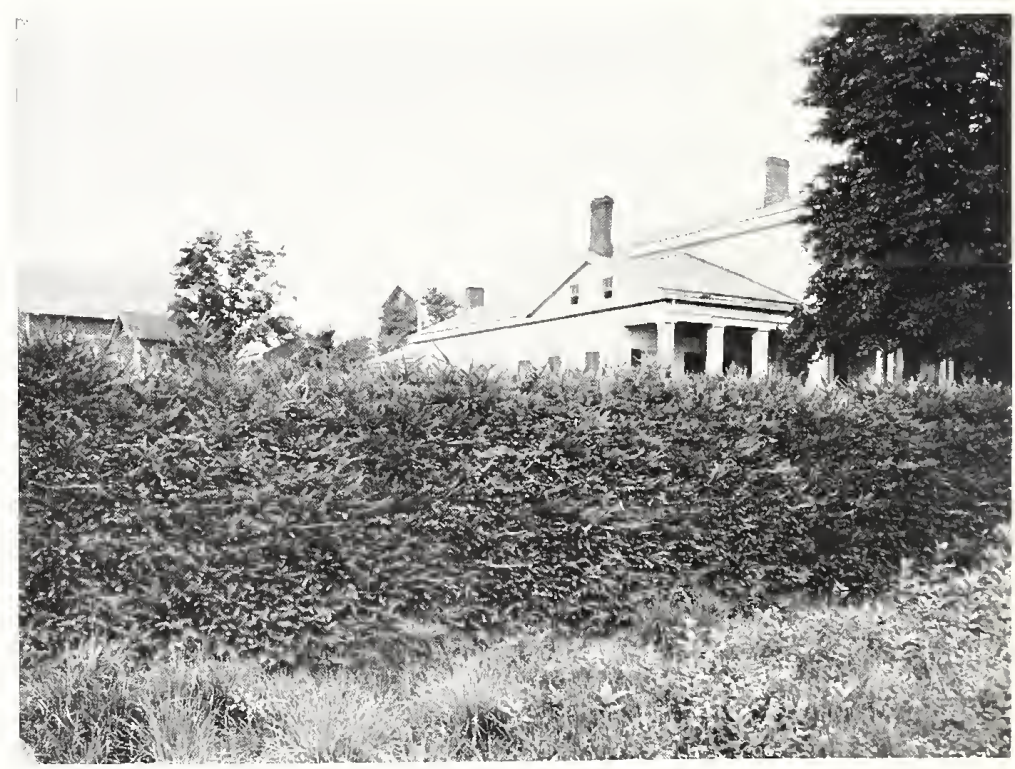

spruce has long been one of the most satisfuctory and beautiful hedges

\section{$10 \quad 100$ \\ $3.40 \quad 34.00$ \\ $600 \quad 60.00$}

$600 \quad 6000$

$300 \quad 3000$ 


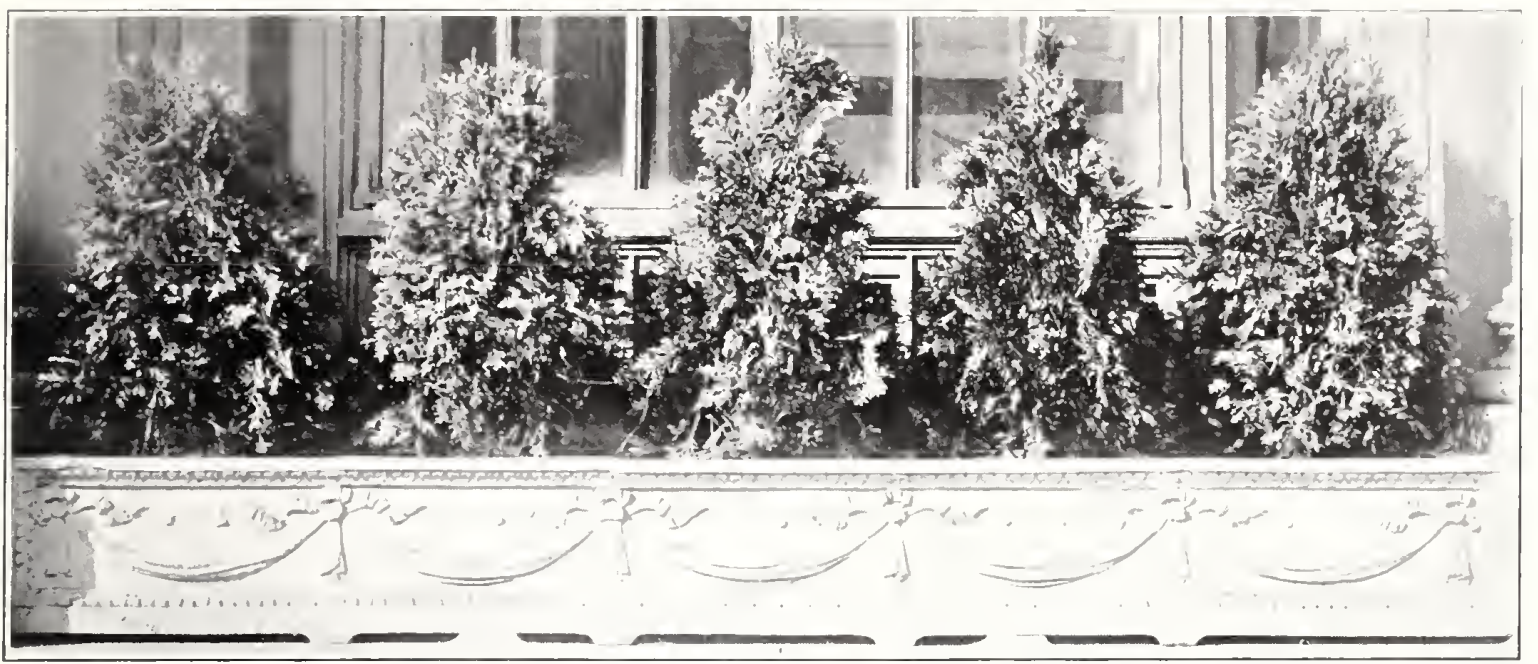

Mill livenengrans

ior

\section{Windaw Haxas}

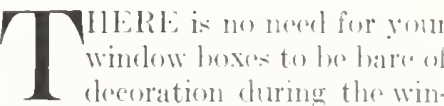
ter montlis. When the early frost in the Fall speil yomr :mmmer window bexes, then is the time to put in refrexhing gresn trees. They will remain green and rigorous al winter. They thrive in the most severe climates.

The elepth of the box, the amount of moisture, and the ex-

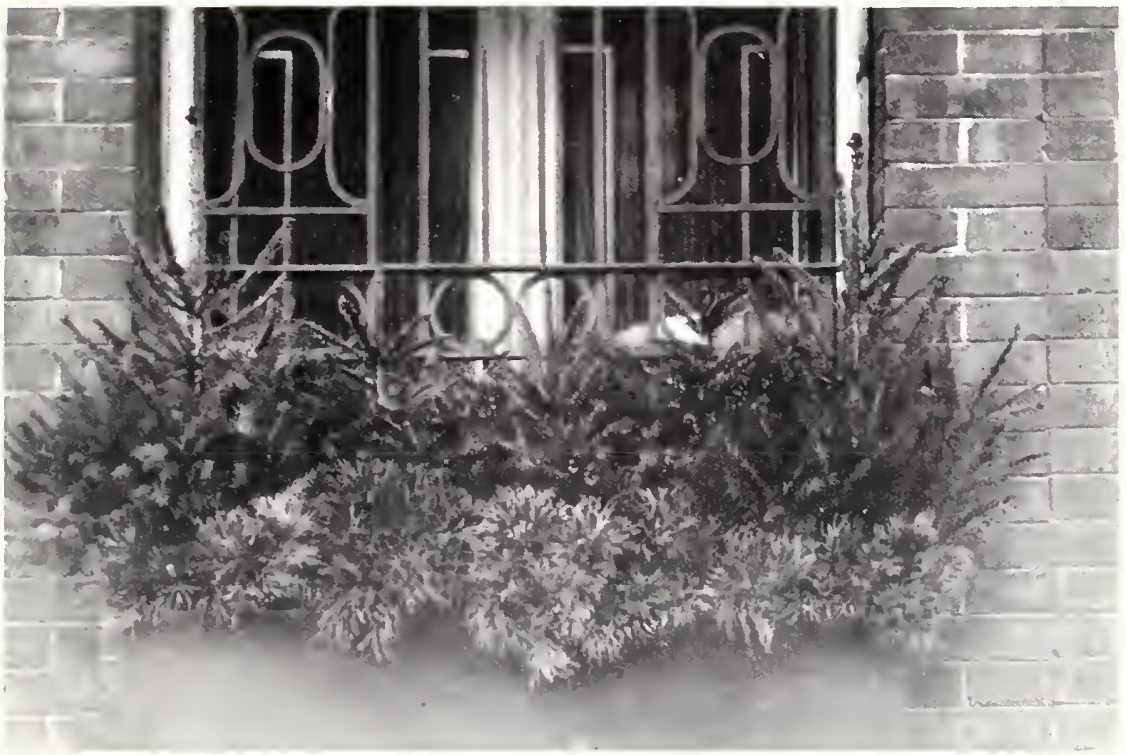

1.combination of Spruce and lugho bine uning tuco rous

posure, govern results. They may be tepended upun to remain green and attractive all churme the winter, up mutil time to put out the summer plants.

A window box planted with growing Lierereens of different varietios and colors will atd much to the appearanee of the porch, windows, or to any rom in the henwe. There are charming foliage effects and spicy fragrance that make Evergreens more and more pepular. For more that twenty years we have been featuring these hardy Everereens for winter wincow box decorations and can recomment the ascortment offerest here.

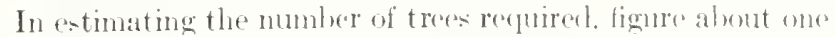

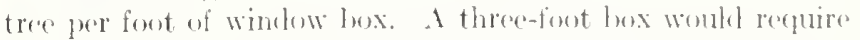
four plants, ete. If your twoxes are fairly wite, eight inches or more, you can use two rows of trees. Plant in gond black dirt. soak well when planting and again just hefore the gromml

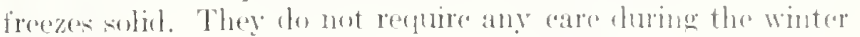
months.

\section{PRICE}

WHITE SPRI'CH Bhuish green-ronical,
complact, shingely

$12-1$ in. high. P1 $\$ 0$

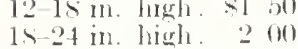

Spereial Trial ciliner

10 Windon Box Exergreens. \$3.75

Four Assorted Vilrieties, ten trees in all. Enough for two four-foot loxes.

3 White spruce

2 Mlurbo Pine

3 American Arborvitae.

2 Woodwart Arborvitae

12 to 18 in

$\rightarrow$ to $10 \mathrm{in}$

12 to 1 s in. Packed lightly for express shipment

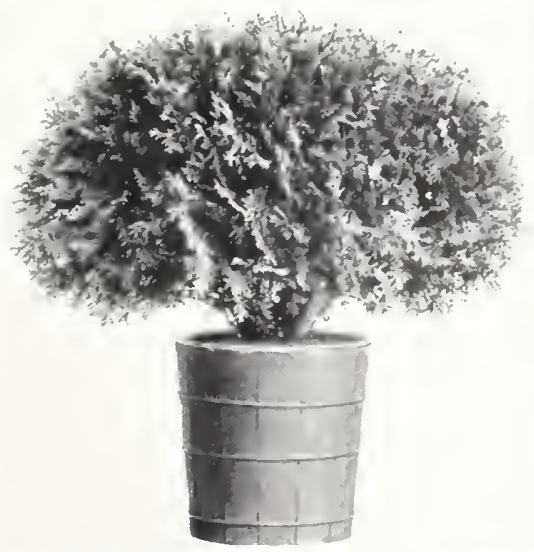

Hoedecord trberritue

3 feet
NII (illO PINE

Dwarf, low-growing, well branched, dark green

a to 10 inches broad. .

AMERICAN ARBORITTAE Dark graen, soft, lacy foliage, bushy PER
12 to 1 inches high,
Is to 2 inches high.

PYRAMIDAL ARBORVITAE

Narrow, pramidal, deep green 12 to is inches high.

MOODMARD GLLOBE . ARBORIITAF Ball-shatpe, close growme, dark grem P'ER : 10 to 12 inches broal. . .3 10

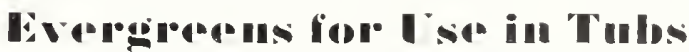

$\mathrm{F}$

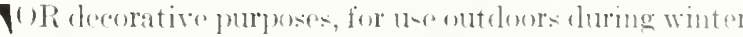
and -ummer, ideal for entranees to homes, stores, tea

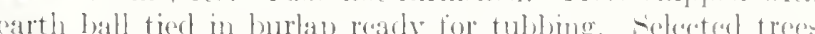
in well matched pairs. (Jnly care rexpured ise oreasional

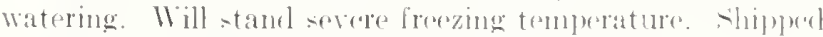

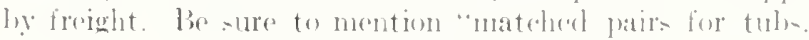

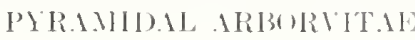

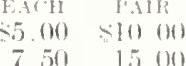

WOODMARI ARBORITTAL

MCOIJ) PINE

$15 \times 15$ inches S.) 00 P.AP 10xis inches. 300 (;) (10)

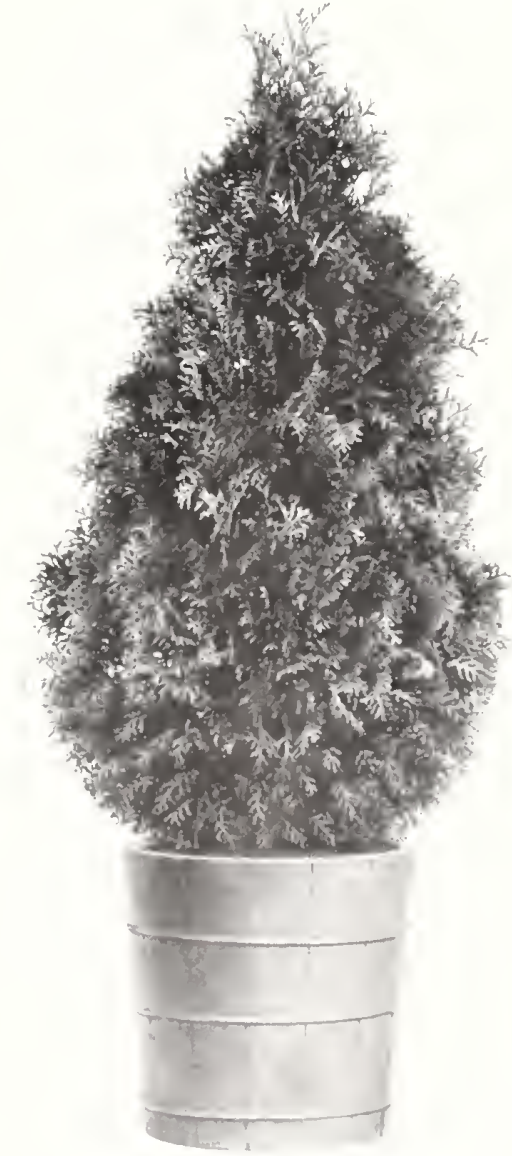




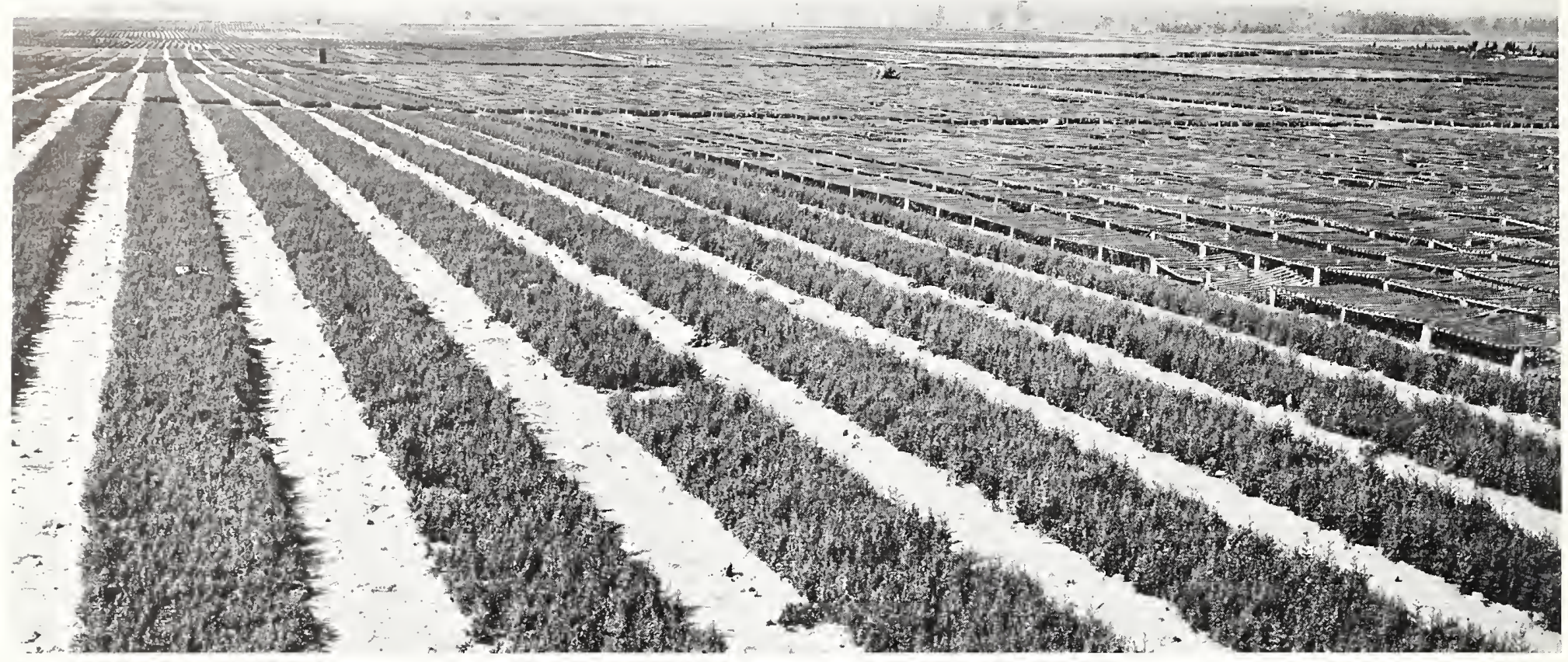

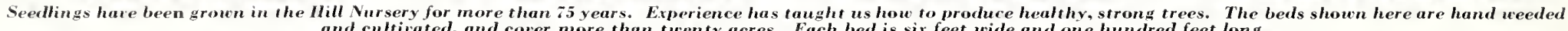

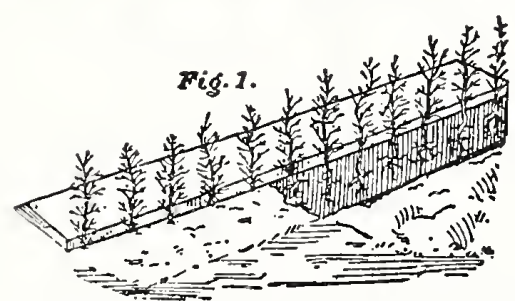

By using a board six feet long and three or four inclies wide, a straight row is easily laid ont. With a sharp spade, dig a trench as shown. Plant the trces, spreading the roots out carefully and Evergrens be planted about the same depth as in the mursery.

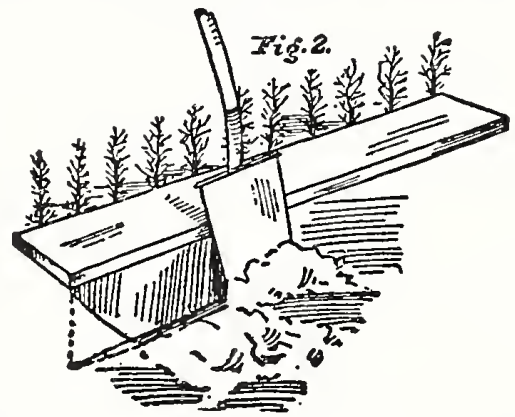

When the first row is planted, proceed as slown, in cutting the next trench. This method not only makes straight rows of crowding. Where the roots are crowded into sinall holes in poorly prepared soil, it cannot be expceted that the growth will be any thing but slow and disappointing.

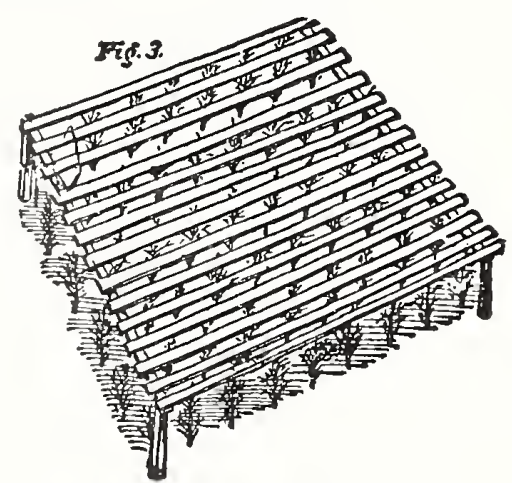

When the planting is completed as shown in figure thrce, a shade should he immediately constructed and placed in position to protect the trees from the severe sun the first season.
This lath ghade should be set on stakes and elcvated 8 or 10 inches above the top of the seedlings.

Space should be left between the lath as shown so the shate will not be too heavy. An opening equal to the width of one lath is recommended so that shade covers only one-half of the

\section{Hill Evergheen Seedlings}

CEEDLINGS are the smallest trees that can be offered for sale. They average two years old. Some are only two ycars in the fast growers and some are three years of age.

For best results seedlings must be planted in beds and covered with shade of some kind for one year as recommended in the planting instructions given on this page. The trees are prepared for shipment in bundles of 50 of the same variety and size and orders should call for multiples of 50 .
All Hill Evergreen seedlings are grown from seed from known origin. We obtain seeds from our own collectors who gather them in localities known to produce the best type of trees.

Only the following listed trees are available as seedlings. Horticultural varieties are not grown from seed but must be propagated from grafts or cuttings. These may be purchased in sizes as listed on pages 49 , 50 and 51

Small lots of seedlings can be sent by parcel post or express. 1,000 seedlings when packed for shipment will weigh from twenty-five to fifty pounds.

Seedling trees are put up in bundles of 50 of the same variety and size, and orders ean be filled only for uniform bundles.

White Fir

Nikko Fir.

Chinese Juniper

Common Juniper (Communis)

Prostrate Juniper

Colorado Juniper

Redcedar

European Larch

White Spruce.

Colorado Spruce

Austrian Pine.

Scotch Pine

Ponderosa Pine

White Pine

\begin{tabular}{crrr} 
INCH & 50 & 100 & \multicolumn{1}{c}{1000} \\
$4-6$ & $\$ 5.00$ & $\$ 10.00$ & $\$ 80.00$ \\
$4-6$ & 3.50 & 7.00 & 50.00 \\
$6-8$ & 5.00 & 10.00 & 80.00 \\
$4-6$ & 4.00 & 8.00 & 60.00 \\
$4-6$ & 3.00 & 6.00 & 40.00 \\
$4-6$ & 4.00 & 8.00 & 40.00 \\
$4-6$ & 4.00 & 8.00 & 60.00 \\
$8-10$ & 3.00 & 6.00 & 40.00 \\
$6-8$ & 3.00 & 6.00 & 40.00 \\
$4-6$ & 4.00 & 8.00 & 60.00 \\
$4-6$ & 4.00 & 8.00 & 60.00 \\
$4-6$ & 2.00 & 4.00 & 20.00 \\
$4-6$ & 2.00 & 4.00 & 20.00 \\
$4-6$ & 4.00 & 8.00 & 40.00 \\
$4-6$ & 4.00 & 8.00 & 60.00
\end{tabular}

500 of same variety and size at the 1000 rate

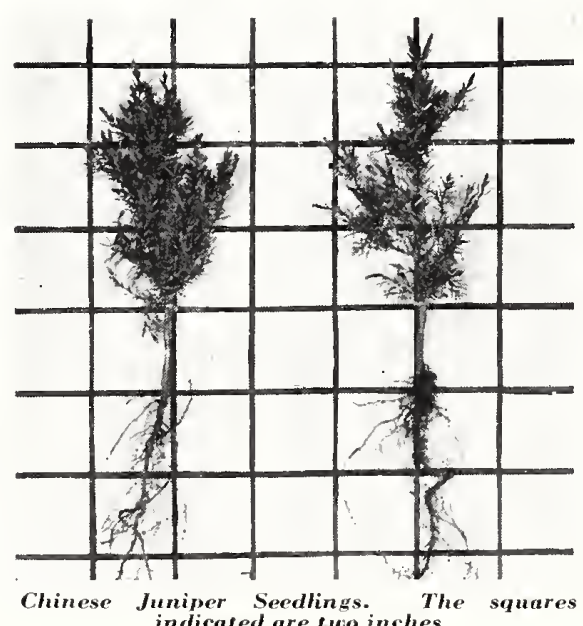

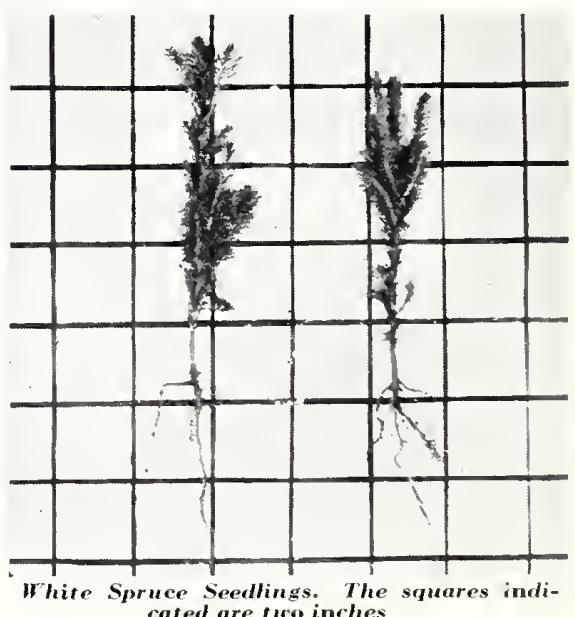




\section{IIII Evergineon tinafits}

$\mathrm{C}$ ERTAIX trees among the Junipers ineluding many ehoice and rare varieties are grown from grafts. They eamot be grown from seed or euttings. This proeess is earried on in the greenhouse and as each tree must be handled separately in a pot, the eost is much greater than for trees grown by other method.

There is a great diffelence in the (puality of grafts. All Hill Juniper grafts are grown on genuine Jumiper L'nderstoeks and the scions used in erafting ale of ample $\rightarrow$ ize so that grafts average 8 to 10 inehos. They are strong and large enough to be set out tireetly into field rows without the usual werk of first planting in beds.

From $21 / 4$ inch pots. shipped only in the Spring during April or carly May

shipped with dirt on the roots
White Leaf Chinese Juniper. .
Blue Column Chinese Juniper
Green Column Chinese Juniper
Green Sargent Juniper.
Vase Shaped Prostrate Juniper
Golden Prostrate Juniper.
Japanese Juniper.
Bar Harbor Juniper
Ion Ehron Juniper
Moonlight Juniper.
Blue Mloon Juniper
Hill's Sitver Juniper
Meyer Juniper.
Cannart Redcedar
Goldtip Redeedar
silver Redcedar.
Hill Dundee Juniper
sichott Redcedir.
Koster Blue Spruce
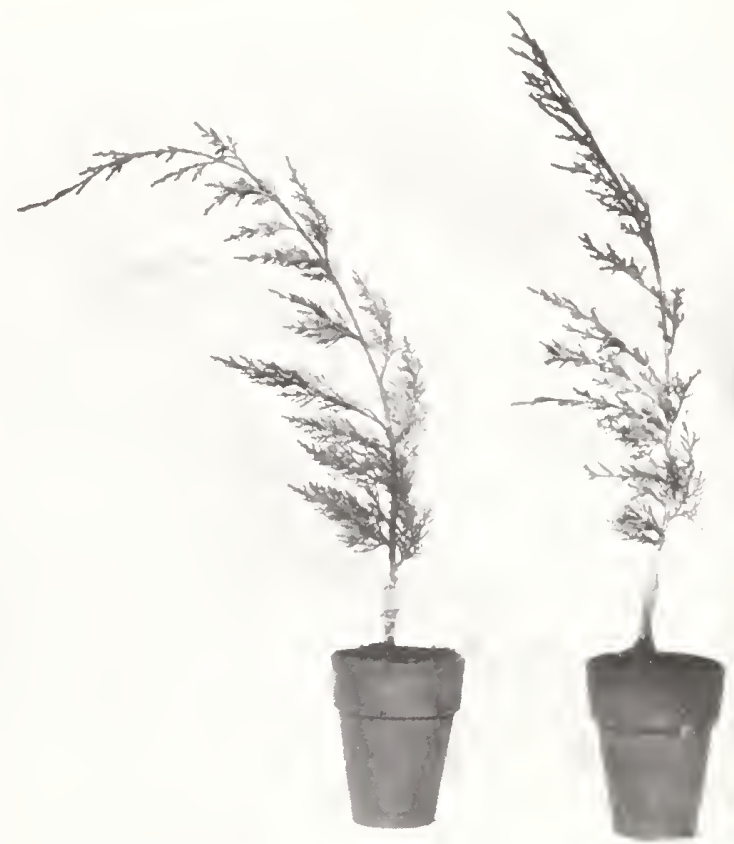

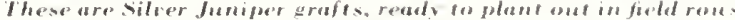

\section{The Home Nurserey}

$\mathrm{P}$

IRKs, emeteles, golf elubs anel private extates having large grounde to deveke, can provide trees for future use by setting out a home nursery. In the plot illustrated below, 1,000 trees are lined out in rows three feet apart with the trees three feet apart in the rows. sueh a layout only recpures a spare 60 liy 150 feet. Write us for special ruotation to meot your inchivelual nexpls.

\section{The Development of a Illome Vursery of}

\section{Evergreens Will IPovide Trees for Furure Ise for Parlks. Cemereries. Golf Clubs amd IPrivate listates}




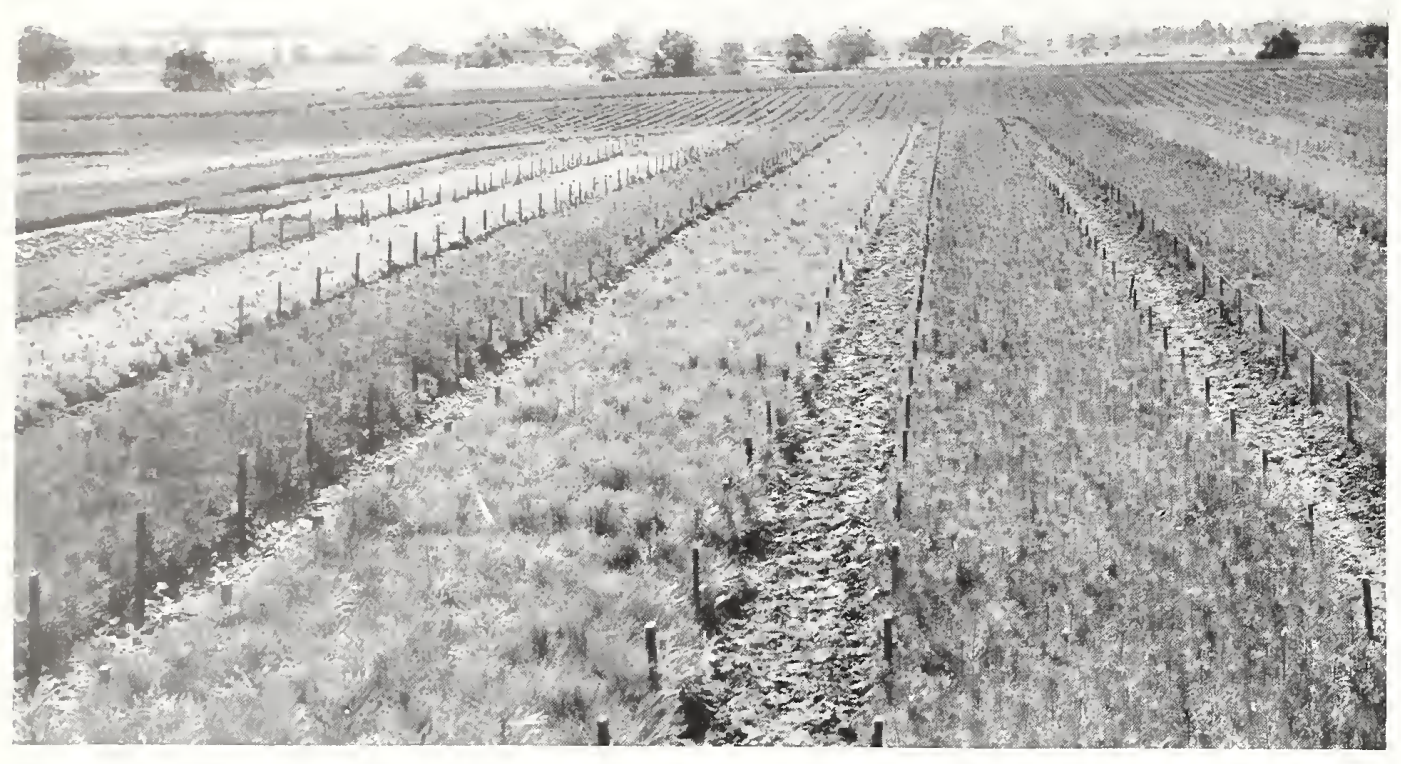

Balsam Fir

Balsam Fir

Concolor Fir.

Concolor Fir

Nikko Fir

Veitch Fir

Pfitzer Juniper

Golden Prostrate Juniper.

Andorra Juniper

Irish Juniper.

Swedish Juniper.

Spiny Greek Juniper

Spiny Greek Juniper.

Japanese Juniper . .

Savin Juniper

Bar Harbor Juniper

Bar Harbor Juniper

Von Ehron Juniper.

Koster Juniper

White Spruce.

White Spruce.

Black Hills Spruce

Black Hills Spruce

Black Hills Spruce.

Norway Spruce.

Norway Spruce.

Colorado Spruce (Mixed blue and green

Colorado Spruce

Colorado Spruce

Large Swiss Pine

Austrian Pine.

Austrian Pine.

Austrian Pine.

\section{INCHES PER 100}

$6-8 \$ 8.00$

$8-10 \quad 16.00$

6-8 20.00

8-10 28.00

4-6 12.00

$\begin{array}{ll}4-6 & 12.00 \\ 4-6 & 12.00\end{array}$

$\begin{array}{ll}4-6 & 12.00 \\ 6-8 & 20.00\end{array}$

$6-8 \quad 40.00$

6-8 $\quad 30.00$

10-12 28.00

$8-10 \quad 30.00$

6-8 24.00

$8-10 \quad 32.00$

$8-10 \quad 40.00$

6-8 $\quad 32.00$

$\begin{array}{ll}6-8 & 32.00 \\ 6-8 & 36.00\end{array}$

8-10 40.00

$8-10 \quad 3400$

8-10 10.00

$\begin{array}{rr}8-10 & 10.00 \\ 10-12 & 14.00\end{array}$

$6-8 \quad 17.00$

8-10 20.00

10-12 3400

$8-10 \quad 14.00$

10-12 16.00

8-10 26.00

$10-1230.00$

$10-12$
$8-10 \quad 20.00$

8-10 18.00

10-12 20.00

$10-12 \quad 34.00$
Ware Arborvitae.
$8-10 \quad 50.00$

6-8 24.00
Scotch Pine.

Scotch Pine

Ponderosa Pine.

White Pine.

White Pine

White Pine.

Douglas Fir

Douglas Fir.

Japanese Yew

Japanese Yew

Japanese Yew.

Dwarf Japanese Yew

American Arborvitae.

American Arborvitae.

Douglas Golden Arborvitae.

Douglas Golden Arborvitae.

Douglas Pyramidal Arborvitae.

Globe Arborvitae.

Little Gem Arborvitae

Geo. Peabody Arborvitae.

Hill Pyramidal Arborvitae.

Hill Pyramidal Arborvitae.

Rosenthal Arborvitae

Rosenthal Arborvitae

White Tipped Arborvitae.

Ware Arborvitae.

Woodward Arborvitae

Woodward Arborvitae

Canada Hemlock

Canada Hemlock.

\section{Bnce and Twice Trans- planted Evergireens \\ (From Beds)}

7 REES in this department are seedlings and cuttings which have been transplanted once or twice as the case may be, and have been grown from three to four years in the beds, making them from five to six years old on the average. They have well developed root systems and branched tops. They are suitable to be set out in field rows like the trees shown in the picture on page 49 . They give much quicker results than the seedlings.

These trees are put up in uniform bundles of twenty-five to the bundle of the same variety and size. In the picture at the left are Scotch Pine, White Pine and Austrian Pine. The first year after transplanting they are shaded with lath racks but the second year the shade is removed so that when received by the planter they are thoroughly hardened up in growth and need no further protection.

\begin{tabular}{|c|c|c|}
\hline & 1 NCHES & PER 100 \\
\hline.$x$ & 6-8 & $\$ 16.00$ \\
\hline.$x$ & $10-12$ & 20.00 \\
\hline $\mathrm{x}$ & $6-8$ & 12.00 \\
\hline $\mathrm{x}$ & $8-10$ & 16.00 \\
\hline $\mathrm{x}$ & $10-12$ & 24.00 \\
\hline. $\mathrm{xx}$ & $12-18$ & 30.00 \\
\hline $\mathrm{xx}$ & $8-10$ & 16.00 \\
\hline$x x$ & $10-12$ & 20.00 \\
\hline $\mathrm{x}$ & 4-6 & 24.00 \\
\hline. $\mathrm{xx}$ & $6-8$ & 50.00 \\
\hline. $\mathrm{xx}$ & $8-10$ & 70.00 \\
\hline. $\mathrm{xx}$ & $6-8$ & 60.00 \\
\hline $\mathrm{xx}$ & $6-8$ & 14.00 \\
\hline $\mathrm{xx}$ & $10-12$ & 18.00 \\
\hline $\mathrm{xx}$ & $6-8$ & 24.00 \\
\hline. $\mathrm{xx}$ & $10-12$ & 34.00 \\
\hline $\mathrm{xx}$ & $6-8$ & 24.00 \\
\hline. $\mathrm{xx}$ & $8-10$ & 30.00 \\
\hline $\mathrm{xx}$ & $6-8$ & 30.00 \\
\hline $\mathrm{xx}$ & $8-10$ & 24.00 \\
\hline $\mathrm{xx}$ & $8-10$ & 20.00 \\
\hline $\mathrm{xx}$ & $10-12$ & 28.00 \\
\hline. $\mathrm{xx}$ & $6-8$ & 20.00 \\
\hline $\mathrm{xx}$ & $8-10$ & 24.00 \\
\hline. $\mathrm{xx}$ & $6-8$ & 30.00 \\
\hline $\mathrm{xx}$ & $6-8$ & 24.00 \\
\hline $\mathrm{xx}$ & $8-10$ & 28.00 \\
\hline. $\mathrm{xx}$ & $6-8$ & 30.00 \\
\hline $\mathrm{xx}$ & $8-10$ & 34.00 \\
\hline $\mathrm{xx}$ & $4-6$ & 10.00 \\
\hline. $\mathrm{xx}$ & $8-10$ & 40.00 \\
\hline
\end{tabular}

All the above trees are tied in bundles of 25 . Orders should call for multiples of 25

\section{Planting Inst roretions}

$\mathrm{T}$ HE location should be selected where the soil is well drained, loose and workable and open to the full sun. The ground should be worked up, spaded and raked thoroughly, and when planting is done on a large scale, plow deep and thoroughly pulverize the ground. If possible, it is a good advantage to have the ground prepared several months in advance. Thorough preparation of the soil cannot be over estimated. Where well rotted manure is a vailable, this can be applied in limited quantities on top of the ground before the spading begins and thoroughly worked into the soil. Great care should be taken, however, to see that no green manure is used or other strong fertilizer.

Keep the roots of the trees thoroughly moist until they are in the ground. Do not allow the wind and sun to dry out the roots. This precaution can easily be taken by keeping them in a box or taking but a small quantity out of the box at a time, covering the roots with a wet piece of burlap or with moss.

After digging the holes, spread the roots out as soon as possible and pack the dirt around the tree firmly.

Aside from frequent cultivation during the first season and occasionally

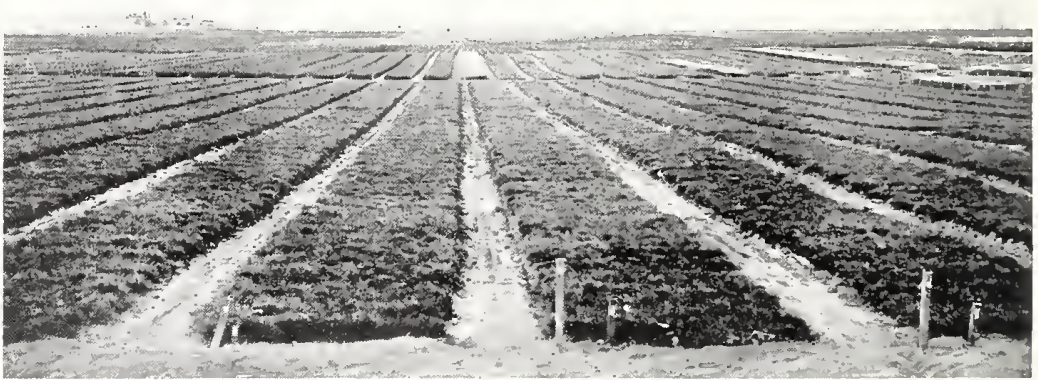

Hill Mugho Pine of the true fharf type has been a leading specialty at the
IIIl Nissery for many years

watering in a severely dry summer, no further attention is required at this stage of growth. We recommend planting trees in rows about three feet apart with the trees two feet or three feet apart in the row, depending upon the variety and how long they are to stand before being again transplanted. 


\section{Twice Tramsplamted Treens}

(From Fiold Rones.

$\mathrm{T}$ YHEsE are the largest trees we sell in the clean-root (not halled and burlapped sizes. In mont catses trees are five to seren years old. They are serdlings, cutting- or graft which have been preriously trancplanted into beds and again moved into field rows. They have well developed roots and tops. While intended for nur-ery planting -they are often uxed in their permanent location for wintbreaks, hedges, window boxes and other unes. They are the same trese we une oursedves to grow on for specimen trees. In two to five years you can grow choice specimen trees - witable for the fine-t landseape work.

The twice transplanted trees offered on thipage are put up in uniform bundles of five trees of the same variety and-ize and order: should call for multiples of five. When packed for shipment the trees average 50 to 100 poumd per laundred trees. They are usually sent ly express, although lareer quantities can safely besent by freight. Detaiked instruetions for planting are furnished with each order.

Chinese Juniper

Chinese Juniper

Chinese Juniper

Pfitzer Juniper.

Pfitzer Juniper.

Pfitzer Juniper.

Prostrate Juniper

Prostrate Juniper

Golden Prostrate Juniver

Golden Prostrate Juniper

Indorril Juniper

spiny Greek Juniper

Sitvin Juniper

Colorado Juniper

Colorialo Juniner

Retleetlar

Redcediar

Cannart Redcediur

Silver Redcedir.

White spruce.

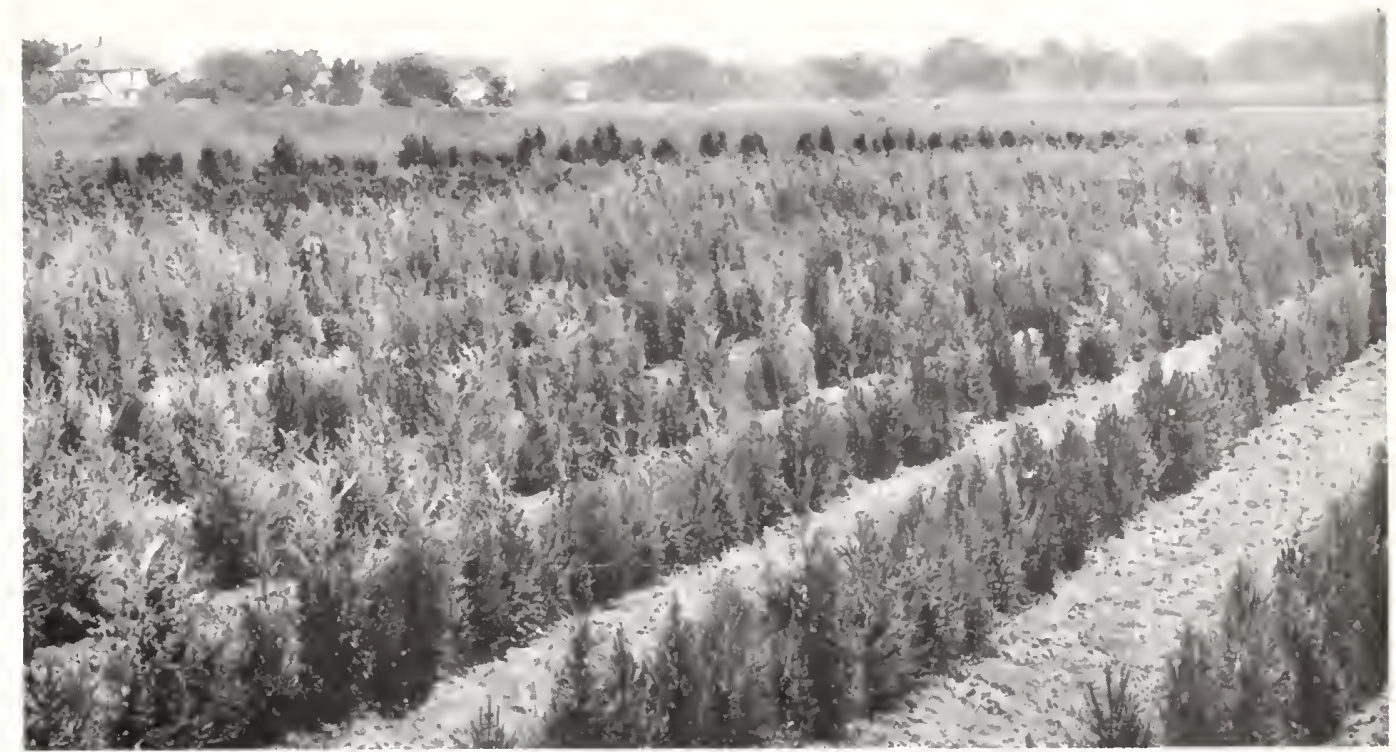

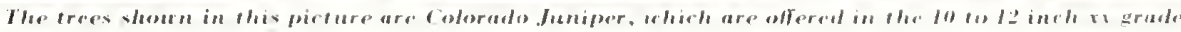

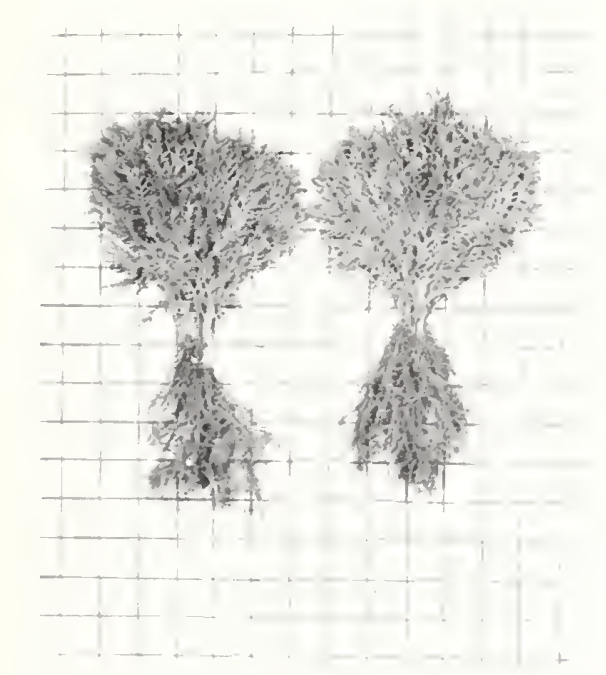

Howduard trboritae. with such fibrews reot sustem and well-dectoped tops, mahe friends and nese customers. Promidal frlurvitue in the center picturt
White spruce

White spruce

Norway sipruee

Norway spruce

$\mathrm{xx} \quad 10-12 \quad 82 \quad 40 \quad 82400$ Norwily siprue

Xx 12-1s 2 60 2s 00 Colorado sipruce stelected blue

xx 1s-2t 3 t0 34.00 . Wugho Pine

$\mathrm{xx} \quad \mathrm{S}-10 \quad 300 \quad 3000 \quad$ Nugho Pine

$\mathrm{xx} \quad 10-12+00 \quad$ t1). 00 sooted Pine

$\mathrm{xx} 12-1 \mathrm{~s} \quad \mathrm{~s} 00$ so 00 seoteh Pine

$\mathrm{xx} \quad \mathrm{s}-10 \quad 3.00 \quad 30.00 \quad$ White l'ine

$\mathrm{xx} \quad 10-12 \quad+00 \quad$ t) 00 White Pine

$x \quad 8-10 \quad 500 \quad 5000 \quad$ Doughtis Fir

$\mathrm{xx} \quad 10-12 \quad 1000 \quad 100.00 \quad$ Douglas Fir

$\mathrm{xx} \quad 8-10 \quad 3 \quad 40 \quad 34.00$ Amerisan Arborvitite

$\times x \quad 10-12 \quad 500 \quad 5000$ American Irborvitat

$\mathrm{xx} \quad s-10 \quad+00 \quad 40.00$ Ameriman Arborvitae

$\mathrm{xx} \quad 10-12 \quad+00$ 40 00 Hill Pyramilal Arborvitate

$\mathrm{xx} \quad 12-15 \quad 500 \quad 5000 \quad$ Hill Pyramilal Arborvitale

$\mathrm{xx} \quad 18-24 \quad$ (i. 100 b0 00 Hill Pyramulial Arborvitae

$\mathrm{xx} \quad 24-36 ; \quad 900 \quad 9000$ Ware Arborvitae

$\mathrm{xx} \quad 12-15 \quad 12.00012000$

$\mathrm{xx} \quad 12-15 \quad 1200 \quad 120 \quad 000$

$\mathrm{xx} \quad 121>\quad 300 \quad 30100$

Canadia Ilemlock
INGHES $10 \quad 100$

$\mathrm{xx} \quad 1 \mathrm{x}-2+\$ 400 \quad 840 \quad 00$

$\mathrm{xx} \quad 2+36 \quad(; 00 \quad$ (i) $(00)$

$x \times 1218 \quad 290 \quad 2200$

ix $14-24 \quad 32003200$

$\mathrm{xx} \quad 2436+00 \quad 4000$

$x \quad 12 \quad 1.5 \quad 10 \quad 00 \quad 10000$

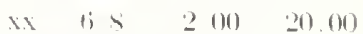

$\mathrm{xx} \quad x-10 \quad+00 \quad 10.00$

$\mathrm{xx} \quad 12-1 \mathrm{~s} \quad 400 \quad 40.00$

$\mathrm{xi} \quad 1524 \quad$ 6i $60 \quad 60 \quad 600$

$\mathrm{xx} \quad 12-15 \quad+00 \quad 4000$

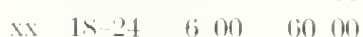

ix $12-1 \mathrm{~s} \quad 400 \quad 4000$

$\mathrm{xx} \quad 1424 \quad 6100 \quad 00.00$

$\mathrm{xx} \quad 12-1 \mathrm{~s} \quad 3 \quad 40 \quad 3400$

ix $18-24 \quad 500 \quad 50.00$

$\mathrm{xx} \quad 21-36 \quad 6 ; 00 \quad(60) .(10)$

xx 12-19 65 $00 \quad 6000$

$\mathrm{xx} \quad 15-24 \quad 700 \quad 7000$

xix $2436 \quad 1100 \quad 11000$

$\mathrm{xx} \quad 12-15 \quad 700 \quad 70.00$

$\mathrm{x} \times 10) 12 \quad$ ti 000 (60) 000

$\mathrm{xx} \quad 10-12 \quad$ (j) 00 (i) 00

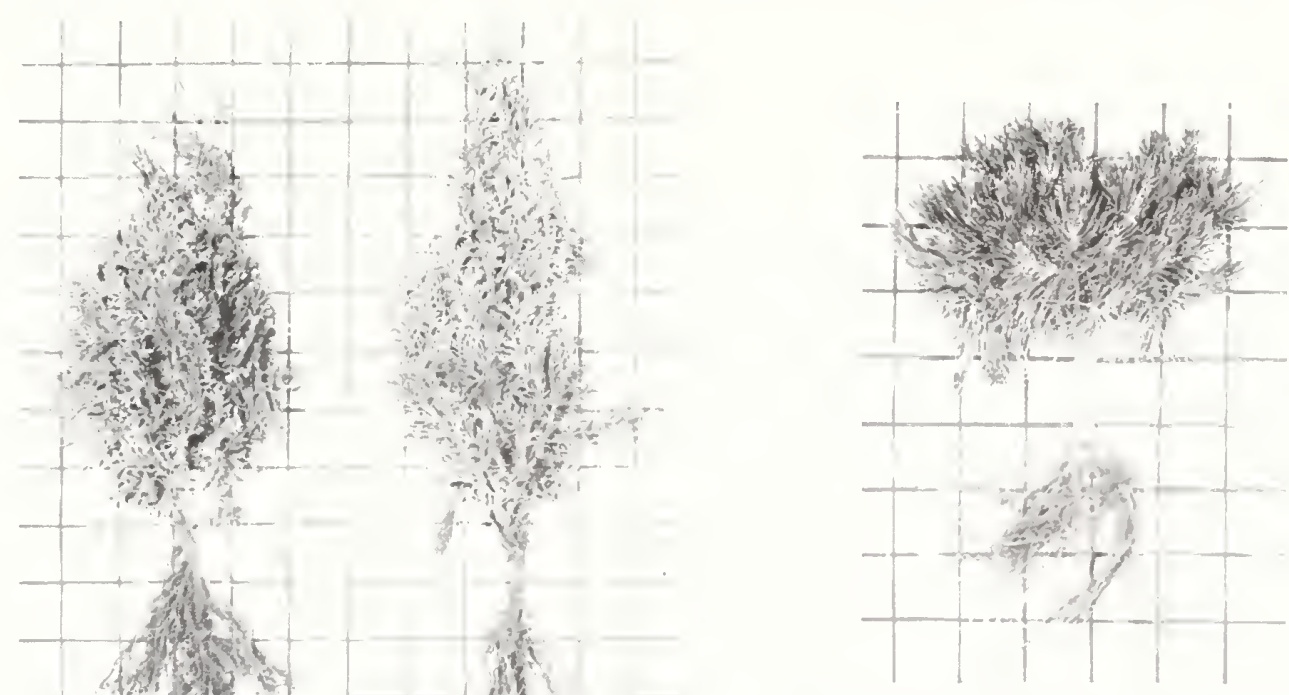

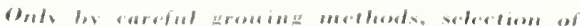
sed and hand wherion of plants. aten this fine

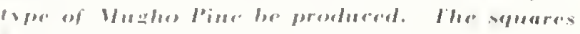

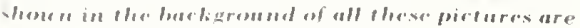
ien irsteres apurt 

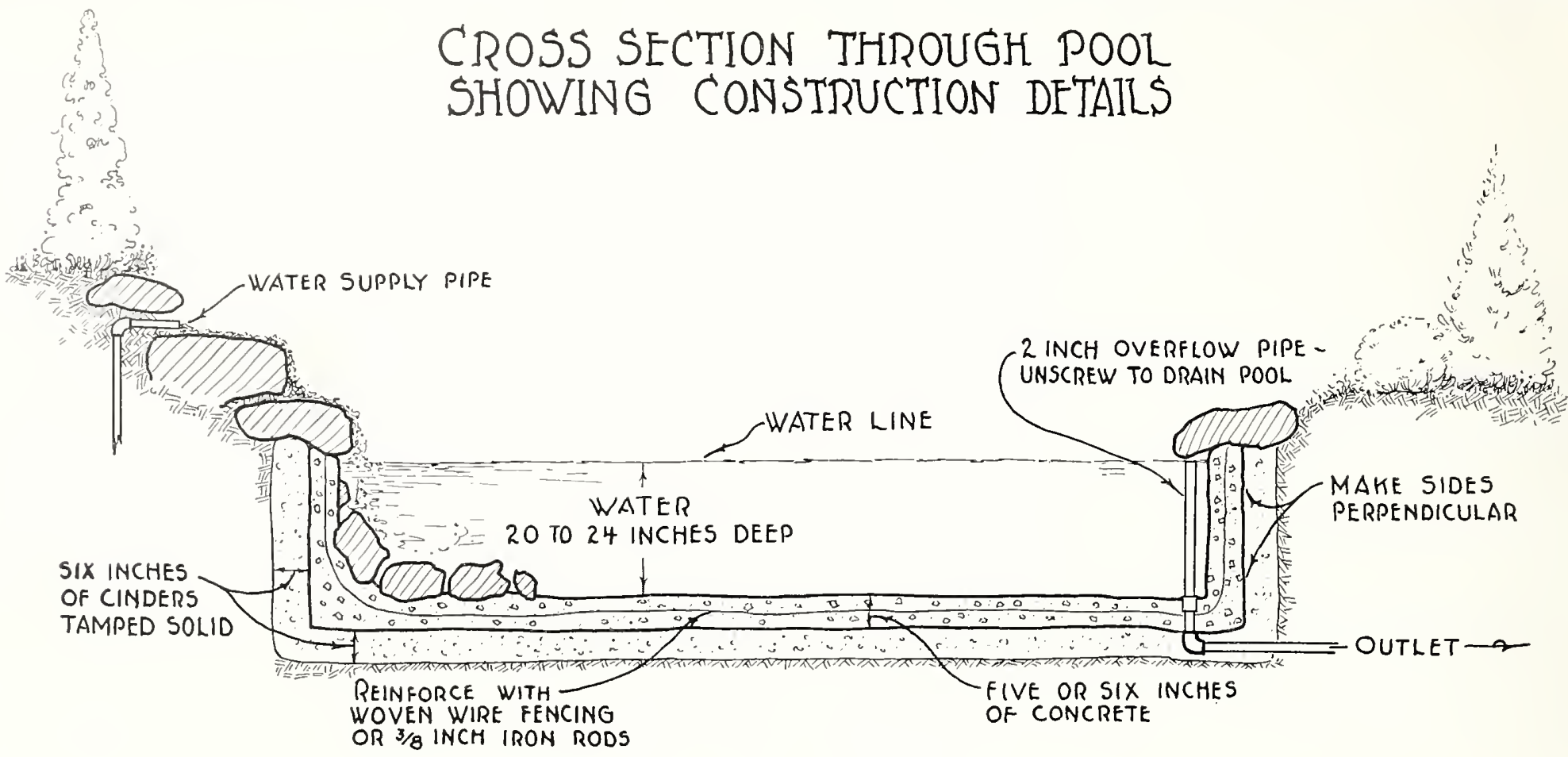

$\mathrm{R}$ CK GARDENS and pools are one of the most interesting and intensive forms of horticulture. The exact form or style of the garden gives opportunity for endless variety. On this and following pages a dozen different pools and rockeries are shown, all of them distinct in character. Rockeries are usually considered distinct from pools although, on grounds of limited space, a combination of a pool and rockery often gives opportunity for a most interesting treatment.

some pools may be built using a clay basin. Concrete, however, is the most practical material for building the basin of the pool and is recommended.

In the drawing shown above, details of construction of a simple pool are shown.

First comes the selection of the site. Wherever a hillside or an uneven, rough piece of land is available, this makes an attractive site for the pool. However, this feature is not essential, as just as attractive a pool may be built on a flat piece of ground. In this instance a sloping background should be given to the flat ground for proper effect

The size of the basin and the shape are matters which must be decided upon to suit the

\section{How to Enilal at Pool}

convenience of the owner. The little pool on the opposite page is twelve feet long and six feet wide at its widest part, with an irregular bounclary. Such a naturalistic style of planting as the one illustrated gives the best opportunity for the use of plant materials and is generally favored for small grounds.

Half of the enjoyment comes from building the pool and while it requires a little painstaking effort, almost anyone with a little help can build a small pool. After the site has been selected, small stakes can be used to outline the general shape of the pool. Excavating can then be done, digging down two feet or two and onehalf feet. Coarse gravel or cinders should then be thrown in the hole and evenly distributed to a depth of about six inches. This should be firmly tamped solid to form the base for the concrete. In climates where there is considerable frost, we recommend laying a piece of rather heavy woven wire fence, or iron rods, or some other reinforcement in the concrete which will help prevent cracking or damage from severe freezing and thawing.
Before mixing the concrete, all outlets and drains must be provided for as shown in sketch, and you should make certain that the various edges of the pool are level. If one edge is too low, the water will run out of course before the pool is full. An easy way to insure level edges is to drive stakes at various points at the edge of the pool. With an ordinary carpenter's spirit level on a straight edged board, establish the correct level and mark it on the stakes. Then you are ready to mix and lay the concrete.

The following proportions in the mixing of concrete will be found entirely satisfactory for making a pool. One part cement, two and onehalf parts sand and five parts gravel. For an extra nice finish which will make the pool waterproof, a top dressing of one part cement and two or three parts sand will give a fine finish.

Thorough mixing is very important in concrete work. If the cement shows in streaks, the mixing has not been well done. Do not mix a larger bateh than can be quickly put into the forms.

Sometimes a very naturalistic effect can be carried out by embedding stones or coarse gravel loosely in the concrete, after it is laid, to take away the artificial appearance.

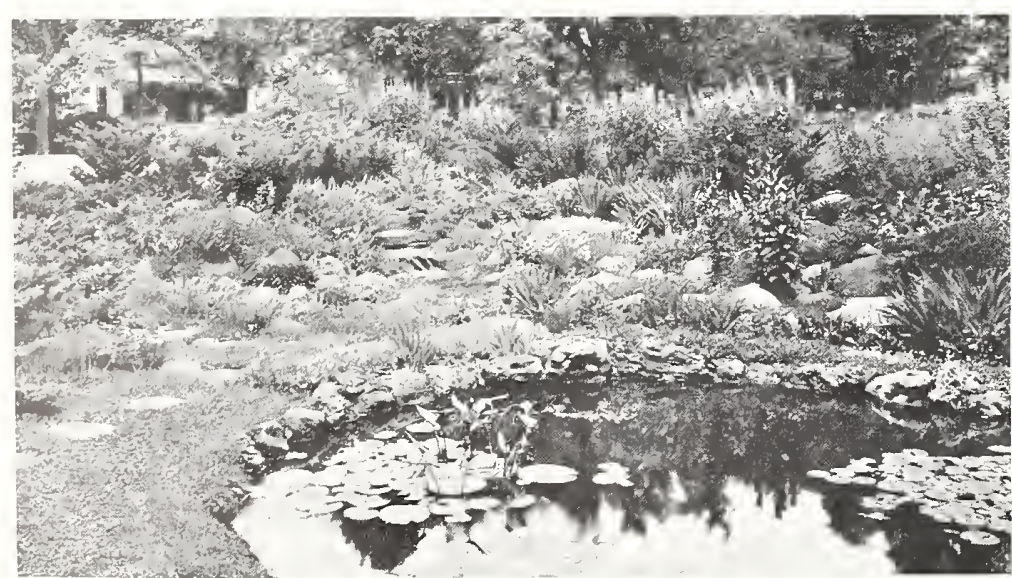
This pool is constructed so that no concrete shows, Porous rocks oucr-hang the
edgc of the water sothat the water covers half of the rocks. This gices a moss covercel edge and more of a nutural and plcusing appcarance

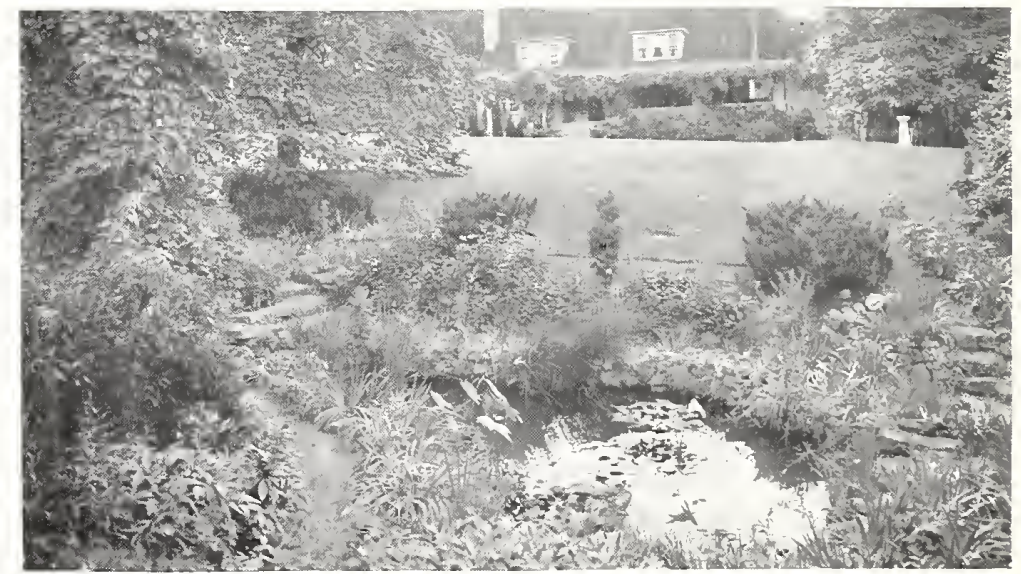

In this poot the builder has succeded rery cell in making it took natural. Various In this poot the builder has sucreeded rery cell in making it hoti naturat. farious appearance of beiug created by nature 


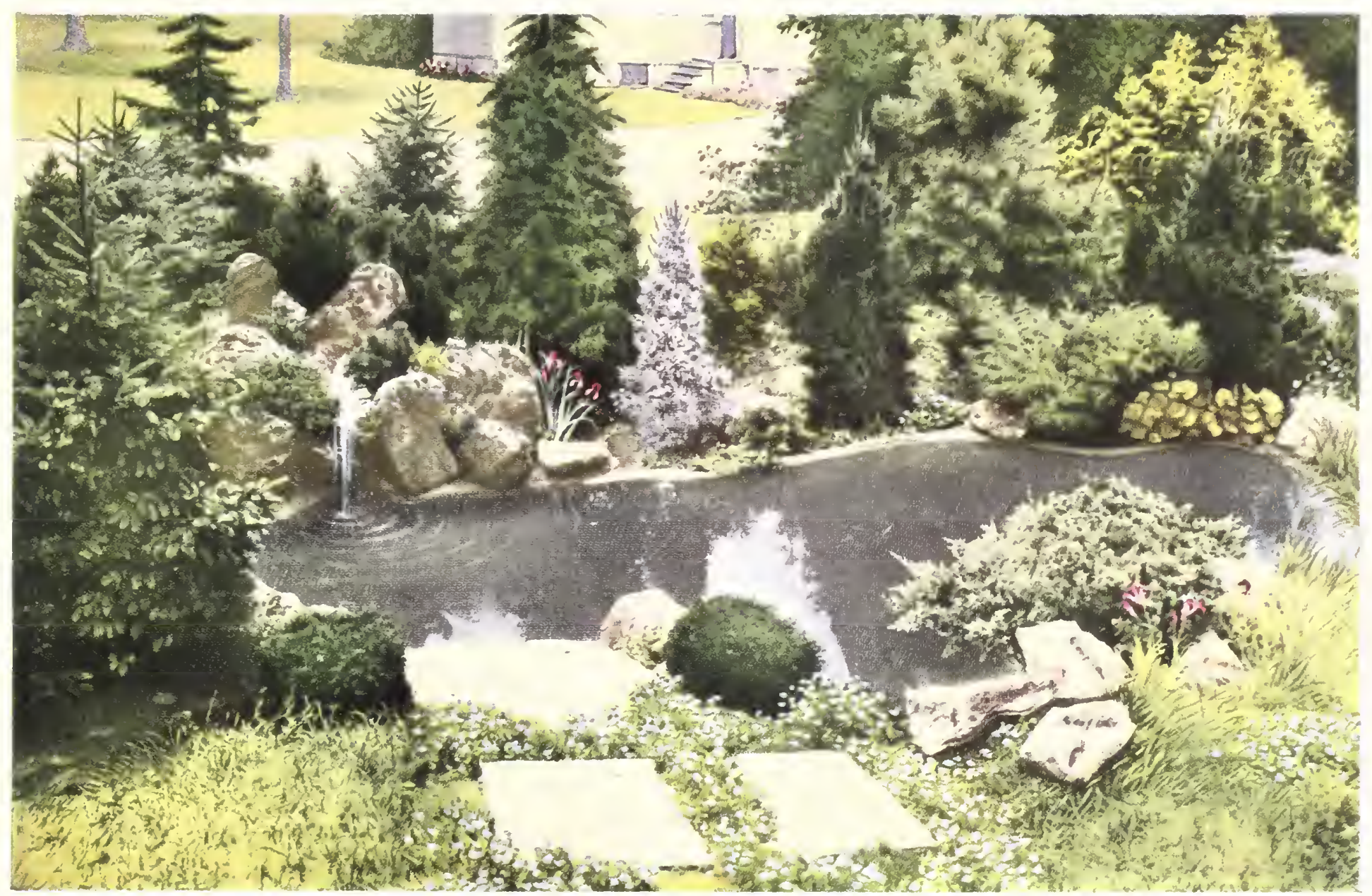

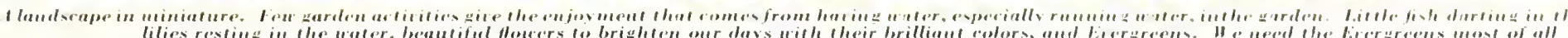

\section{Naluralistic IP(10)}

"IIl, Pharling skeleh

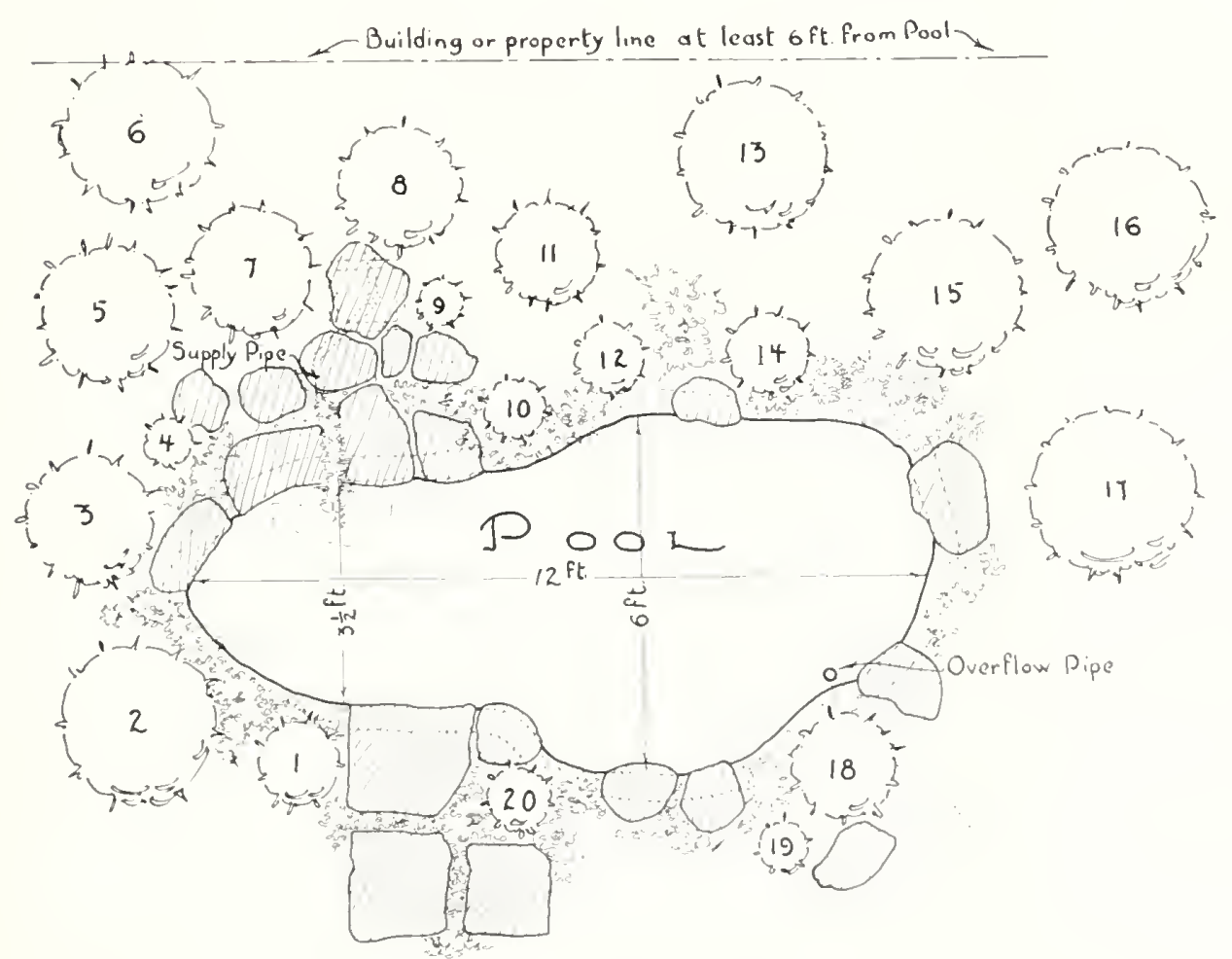

DHIs poul built of ennerete is six feet wide at its widest point, and ahout twelve foet long. It is indicated hy the followine plautine toen Jot all of the trees are thown in the picture, and of eourse the planting could he oreatly simplified, and the enst coulcl he reduced hy using fewer trees and maller sizes. Apme plants, perennials and ammals are not
hown but are easily obtainable and are also neeesary to complete the planting.

Key for sketch shown at left

\section{GROUND PLAN - SHOWING}

LOCATION OF EVERGREENS and SIZE of POOL 


\section{SOME TINE EXAMPIAS OF}

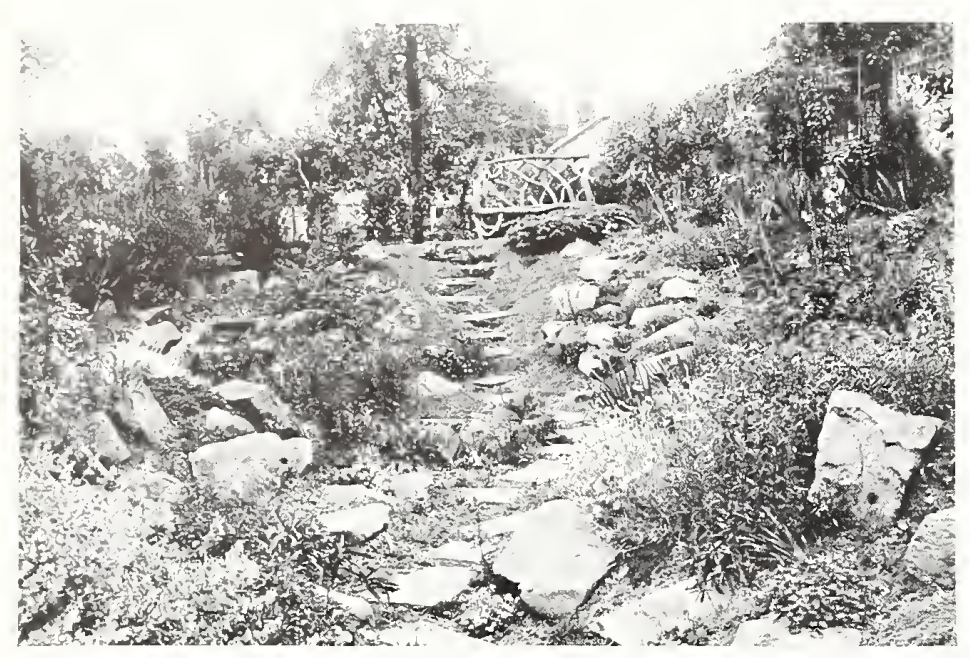

No water is used in this rockery, but advantage is taken of the natural hillside kocks are laid in profusion with no regularity. Along the stone walk, flouers and dwarf Ehergreens are planted in crevices. The path leads up to a rustic seat which commands a riew of the entire garden

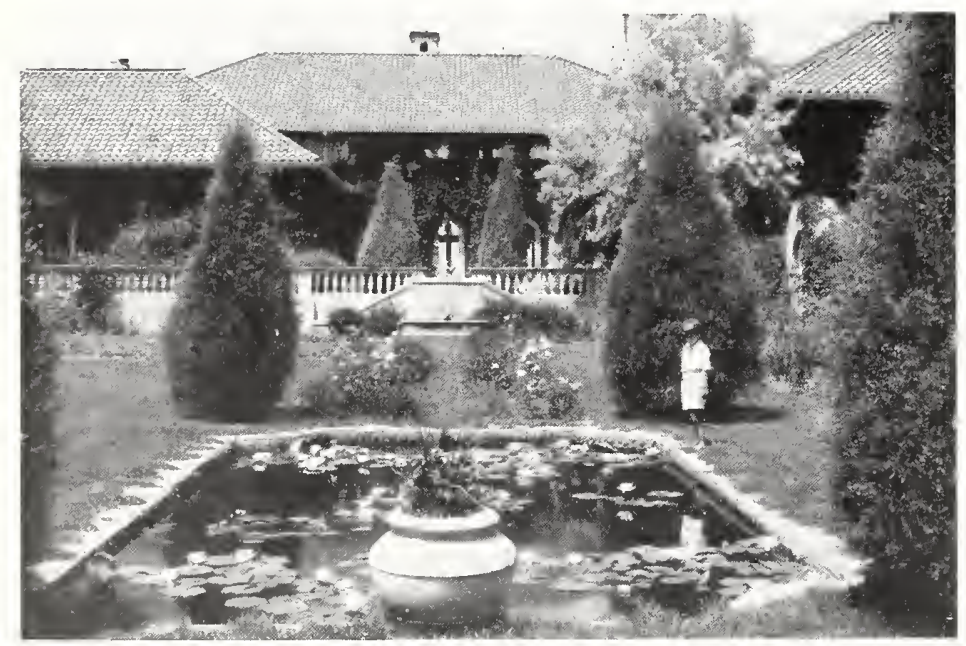

Here is the other extreme of formality of pool construction. This pool is intended as a display for water plants but the ouner has rery wisely taken advantage of the formal grouing habit of the Redcedars to mark the four corners of the pool

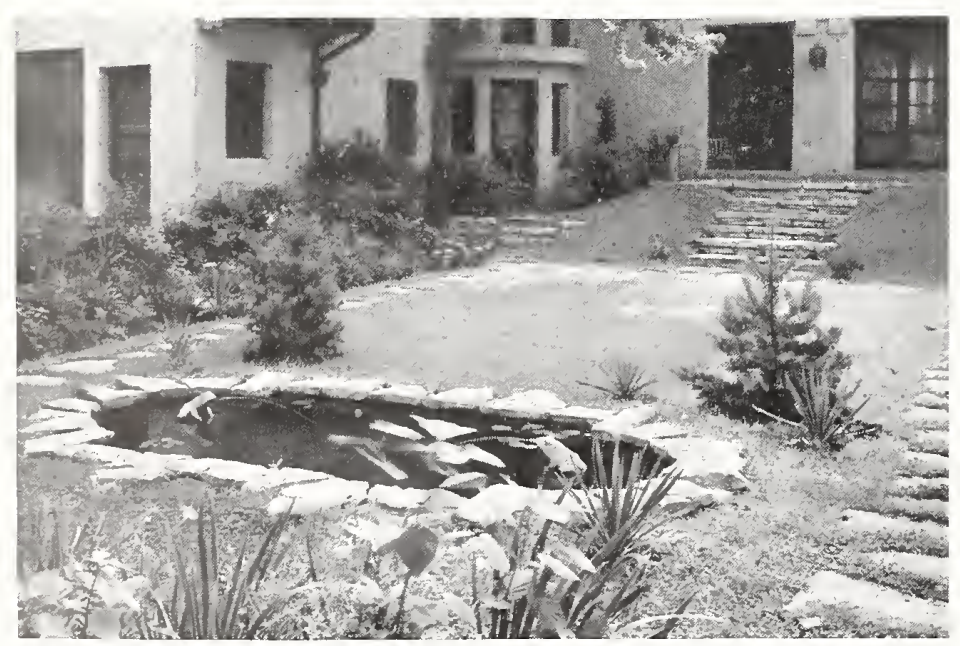

In formal pools such as this one, the use of stratified rocks laid in regular formation forms the outline of the pool. A pair of Scotch lines has been added. Other Exergreens could atso be used here

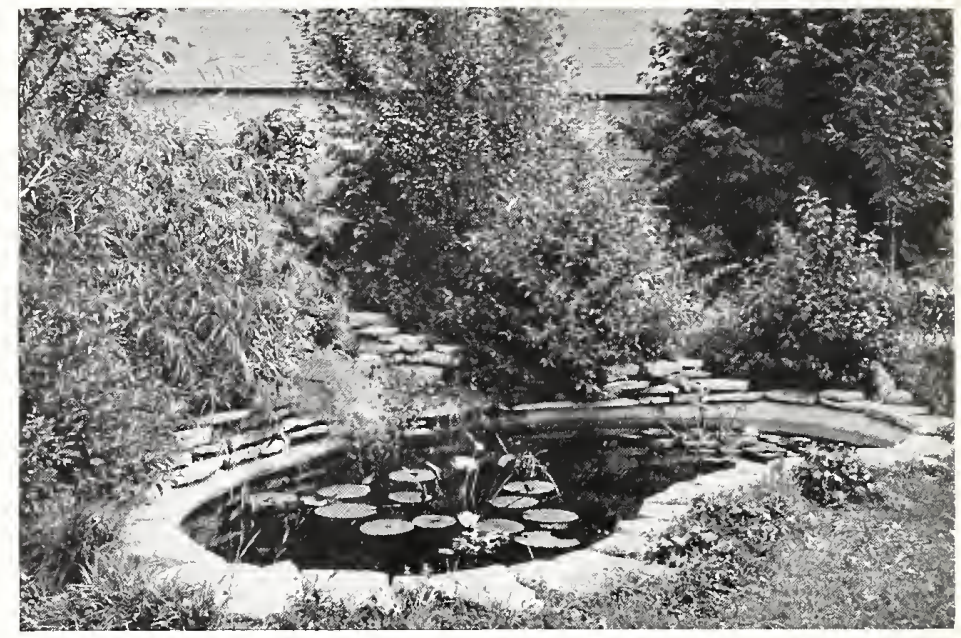

This ouner was handicapped for space in which to place his pool, being obliged to set it next to his garage. By using some quick growing willows and poplars in the background an artistic setting is not marred on this account. The addition of some creeping Evergreens around the front edge of the pool would improve it

$\mathrm{Y}$ OU may use a regular edging of flat or stratified stones which may be embedded in the concrete before it hardens, or the surface may be left entirely smooth. Or it may be decorated with small boulders of whatever type are easiest to obtain in your neighborhood.

Many suggestions for the use of rock plants, building of pockets for alpines, as well as information on how to raise lilics and water plants, can be obtained from nurserymen who spccialize in aquatic and perennial plants. The suggestions which we make here apply only to the use of Evergreen trees which should make the framework or background around the pool and rockery. Flowers and plants can be filled in as space permits.

The artistic and natural appearance of a rock garden and pool is something which you cannot gain from reading books or suggestions. The artistic effect which you may have admired in other pools will furnish an outline for you to follow. The rocks, the trees and plant materials, as well as the location and your own artistic sense will govern your results.

Some of the chief faults in rockeries made by beginners are too much stone and too great regularity. It is better to have a few larger stones than many small ones. The larger you can get the rocks the better for the appearance of your rockery. Broken rocks, pieces of concrete and other unnatural looking objects should never be used. Stones which are rather porous make more interesting subjects than hard boulders. If the porous stones are set so the lower half of each stone is touching the water, they will quickly become covered with moss. Porous stones full of holes and depressions also give opportunity for planting many delicate plants. Round, water-worn boulders are difficult to place to look properly, while

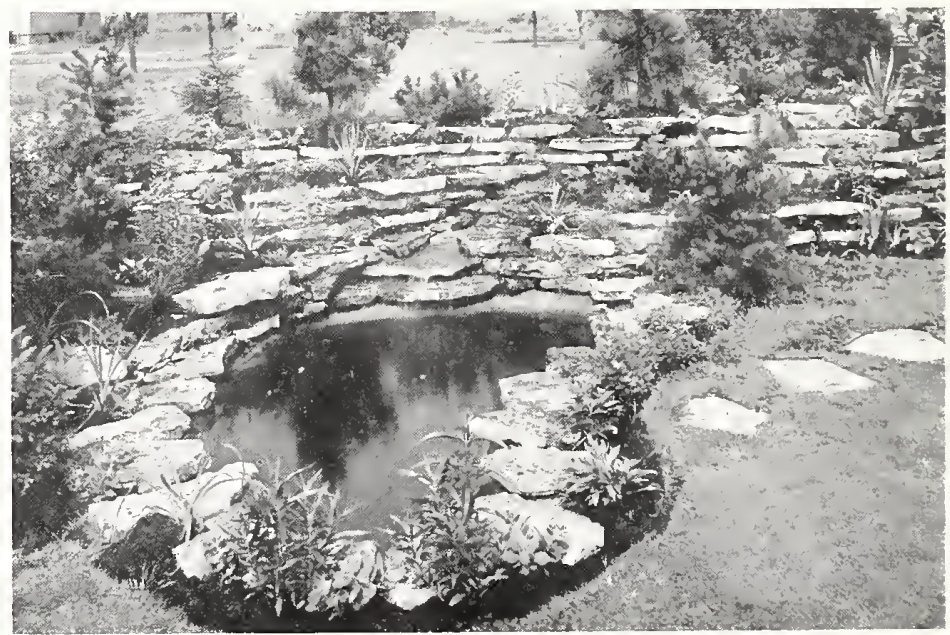

This pool is a combination of rock wall and pool. The rocks here appear too conspicuous and there are more rocks than uould be necessary aronnd a poot of this size. Howerer, the picture uas taken immediately after planting so that time uill naturally soften the effect. Exergreens will grow oter the rocks and ot her plants will help cover then 


\section{IR OCK GAIBIENA INID DOADA}

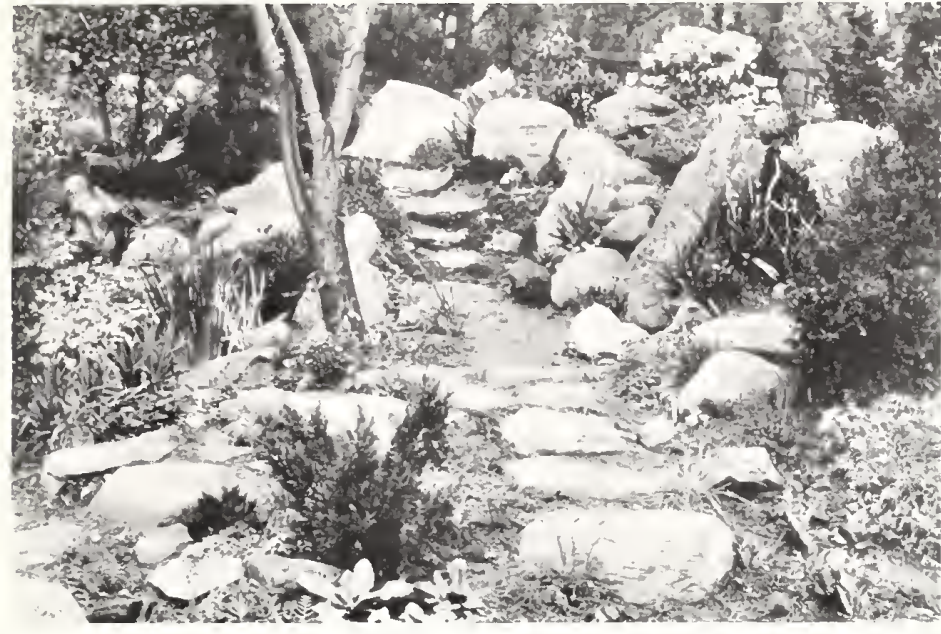

kocheries surh as this, on the hillsides and these which can be buill up taller in

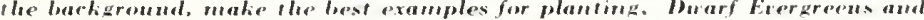
pereunials of carious kinds all combine for vour pleasure in such a garden
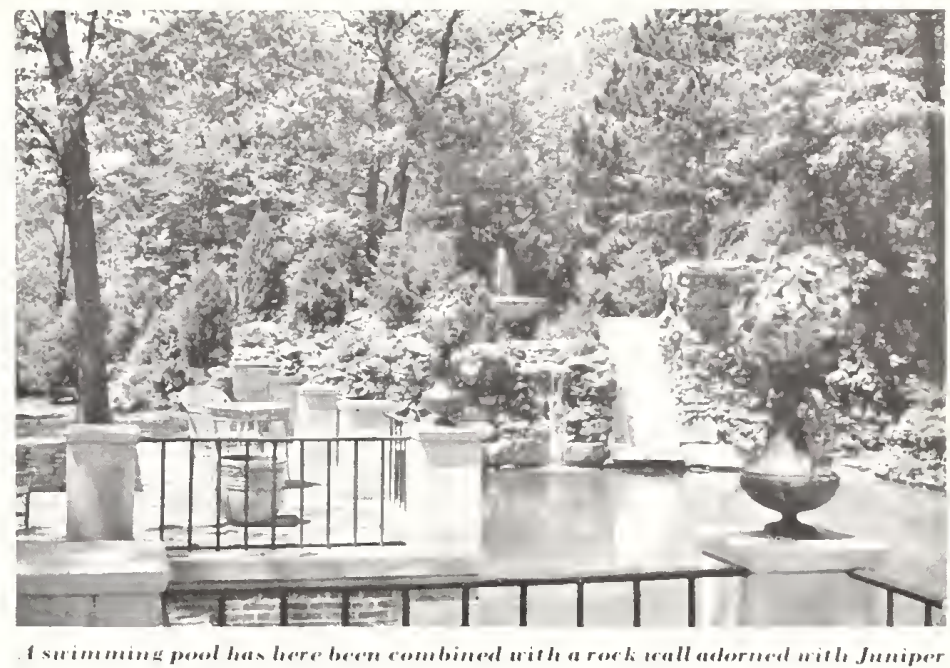

treses. This area diractly adjoining the dwelling combines these tew pardern

fatures in a mont atounal aud artistio manuer exg-shaped rocks are not of mueh use. The extreme of slab-like rorks is equally to be avoiderl.

Evergreens furnish a background of beautiful green foliage for the roekery or pook. Even on a mall seale, a few tall growing trees are necessary to give height and mass to the baekground of the planting. Interesting low and dwarf forms ean be used around the edge of the pool and among the rocks. The listing of various Evergrems and suggestion. for their use in roekeries will be of assistanee to prospective builders.

For overhanging rocks, and orerhanging the ectge of the poot, there are a number of strietly ereeping Evergreens among the Junipers: Hill Waukegan Juniper, Bar Harbor Juniper, Japanese Jumiper, and Sargent Juniper. The Ankorra Juniper might atoo be ineluded in this group. For planting among the rocks there are other of a dwarf habit but slightly more upright in growth, surh as sarin Juniper, Pfitzer Juniper, Prostrate Jumiper, Koster Juniper, Neyer Junipor, I warf Alherta siruce, Mugho Pine, Japanese Tahle Pine, Woodward Arborvitae and Dwarf , Iapanese Yew. For the baekground of the pook or at its horder as a frame to the planting, almost any of the other varieties of Evergreens oflered in thieatakg will prove suitable. All the above mentioned trees are arailabls in various sizes listed in this catakge.

Frequent trimming of plants and trees used in rockeries and around pook makes it possible to we a much wider variety and kerpe trees small and within bounds for many years.

some of the brighter colored Evergrems. such as the bright folden Prostrate Juniper, Croldtip Redeedar and trees of unmwal enlor, have an interesting place in plantings of this kind.

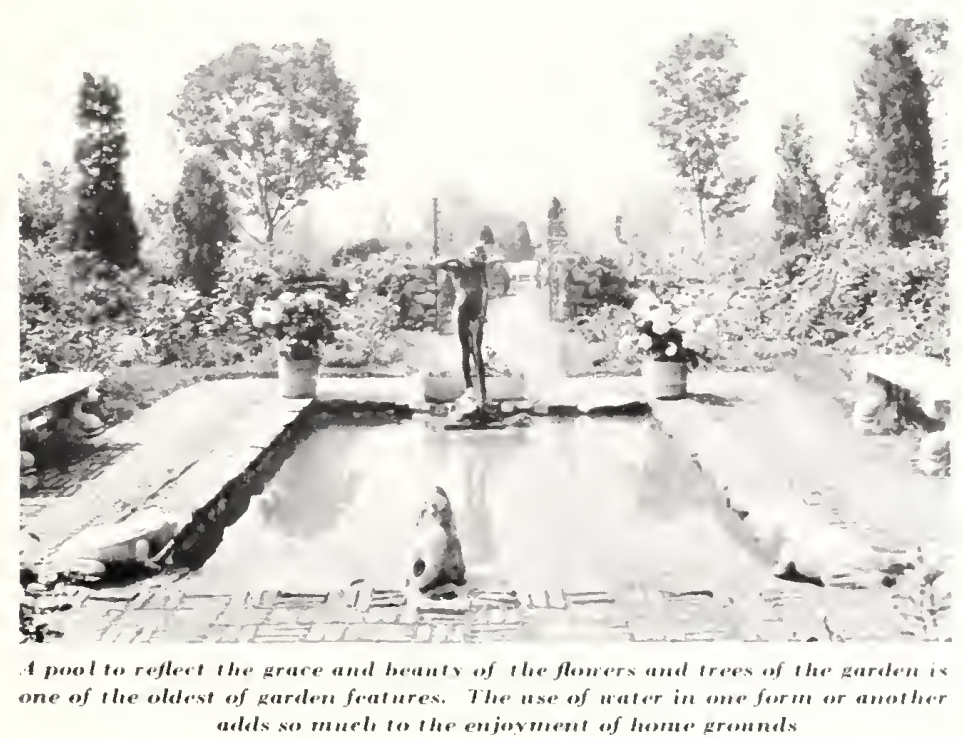

adds so muet to the enjovment of tomus grounds

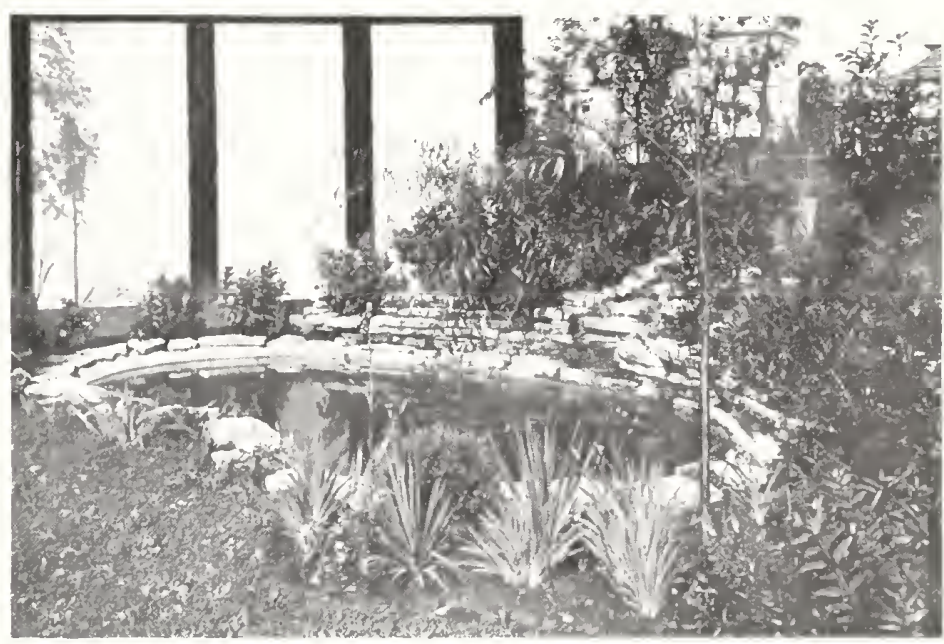

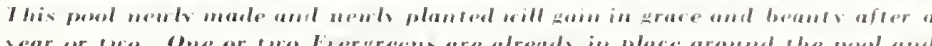

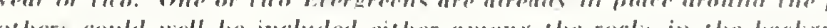

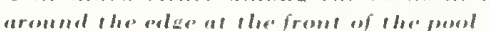

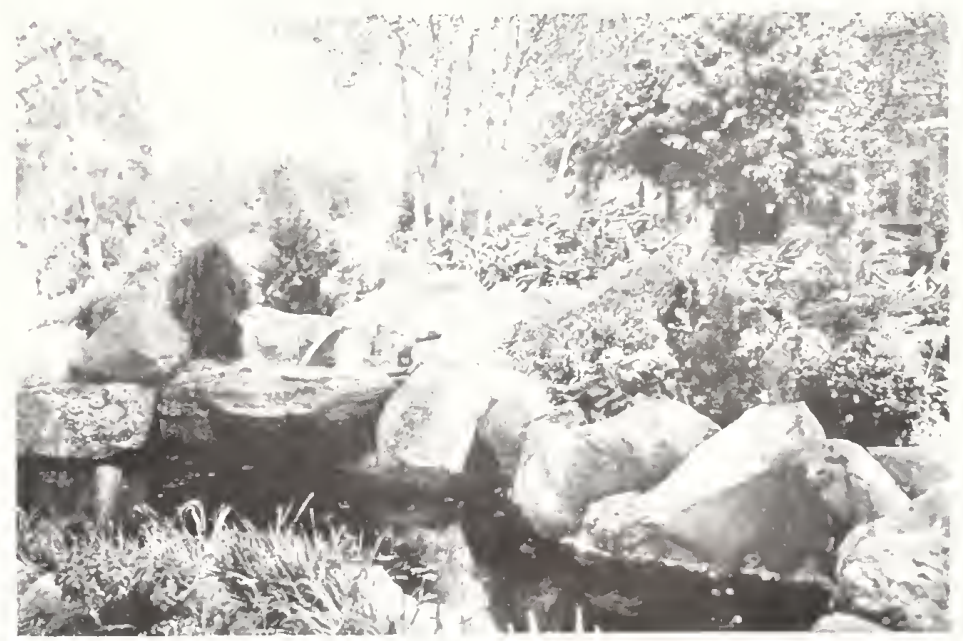

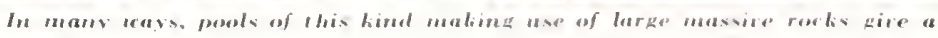

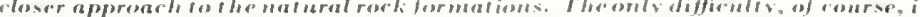
larke restivare usually an be desired 


\section{Simple Lessons in the Use of Evergireens}

$\mathrm{P}$ ROFESSIONAL landscape architects well know that there are no definite rules for landscape work. It is true that the treatment given each landscape development takes into consideration a great many conditions. We make no attempt to give suggestions for landscape developments on a large scale. Naturally, plantings of consiclerable extent deserve the assistance of the best landscape architect available. On the other hand, there are thousands of home owners who, for one reason or another, prefer to do their own landscaping. The illustrations and suggestions given here will give assistance to anyone who desires to improve his grounds in simple landscape design with Evergreens.

\section{SIMPLE DESIGN A FIRST ESSENTIAL}

It is of first importance that plantings be made simple. One of the most common mistakes amateur planters make is the wrong selection of varieties and placing them on the grounds without any definite plan. Oftentimes trees are purchased with no thought of where they are to be used on the grounds, and as the planting is clone at different times the finished planting often results in a mixture of planting materials and in poor arrangement.

By working with this suggestion in connection with the pictures and descriptions in the catalog, any planter can develop his own grounds in an artistic and pleasing manner.

\section{EVERGREENS INCREASE IN VALUE}

When you are making your planting of Evergreens you are adding to the value of your home. Evergreen plantings increase in value each year. They add stability and dignity to the appearance of your home grounds and without question make your home more readily salable.

\section{VARIETY OF SIIAPES IN EVERGREENS}

On page 59 is a sketch showing the wide variety of growing habits available in Evergreens. There is scarcely a landscape need which can not be filled with some kind of an Evergreen.

\section{WIDE RANGE OF BEAUTIFUL COLORS}

There are many color effects which can be worked out with Evergreens. The name "Evergreen" conveys the impression to many people that the trees are only green. There are, however, numerous attractive color variations including various shades of green, blue, golden, silvery and others. Pictures in natural colors are shown in this catalog.

\section{DIFFERENCE IN TEXTURE OF EVERGREENS}

Evergreen foliage is not all alike. In fact, every family of Evergreens has its own beautiful foliage characteristics. Some are soft, dehicate, and artistically formed. In others the foliage is long, heavy and coarse. Some thought should be given in selecting varieties so that the texture of the trec itself will be harmonious with its surroundings.

\section{Build the PIan on Paper First}

Visualize the Results Before Planting

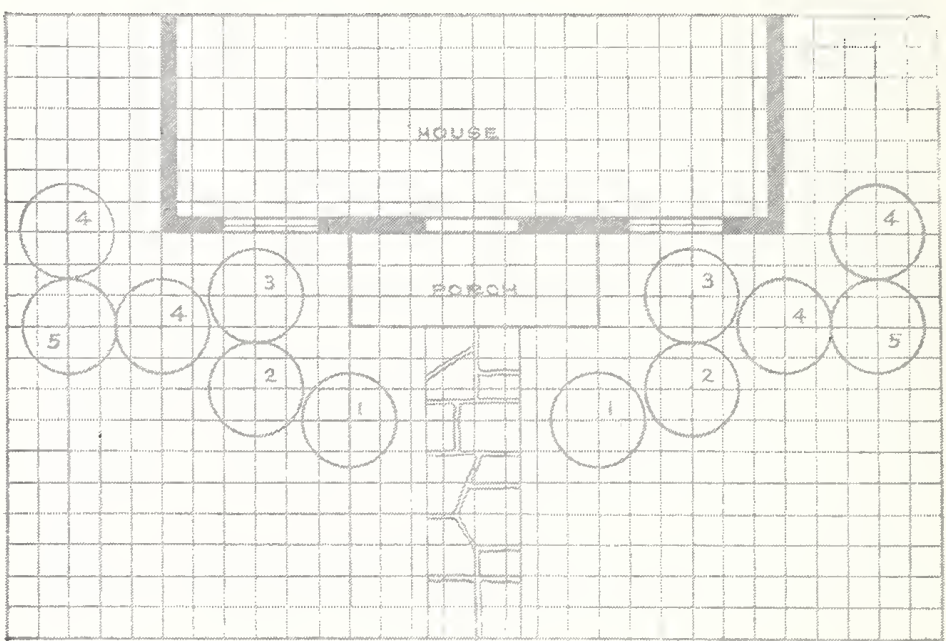

I

$\mathrm{T}$ is easier to change the planting on paper than it is to change the planting after it is in. For this reason it is always an excellent idea to first make a sketch of the planting which you propose to make. To do this to best advantage, accurately draw an outline of the house on ruled paper like the sketch above. If you let each square represent one foot you will then be sure to get the planting done in correct proportion. In this way you can tell exactly how much space there is between windows, doors, etc., and also the number of trees required can be morc accurately estimated.

\section{DISTANCE BETWEEN TREES}

The sketch in the lower left hand corner of this page shows the minimum planting distance. Three feet is the closest that trees should be set to each other or to buildings. Four feet is not too far apart, although planters sometimes set them close in an effort to get a more immediate effect.

\section{AVOID CROWDING}

Right here is a good place to mention that a planting containing too few Evergreens is more desirable than a planting which is overdone. A few trees properly located will usually be more pleasing than a larger number of trees crowded closely together.

\section{What Can IBe Doue by Trimming}

$\mathrm{F}$ EW Evergreens will grow exactly in the shape that nature desired. A great deal can be done by trimming. Trimming not only helps to keep trees within bounds, but greatly improves the general appearance. Except where necessary it is better to avoid closely trimmed, formal looking specimens. In the sketches below some idea of results of trimming is shown.

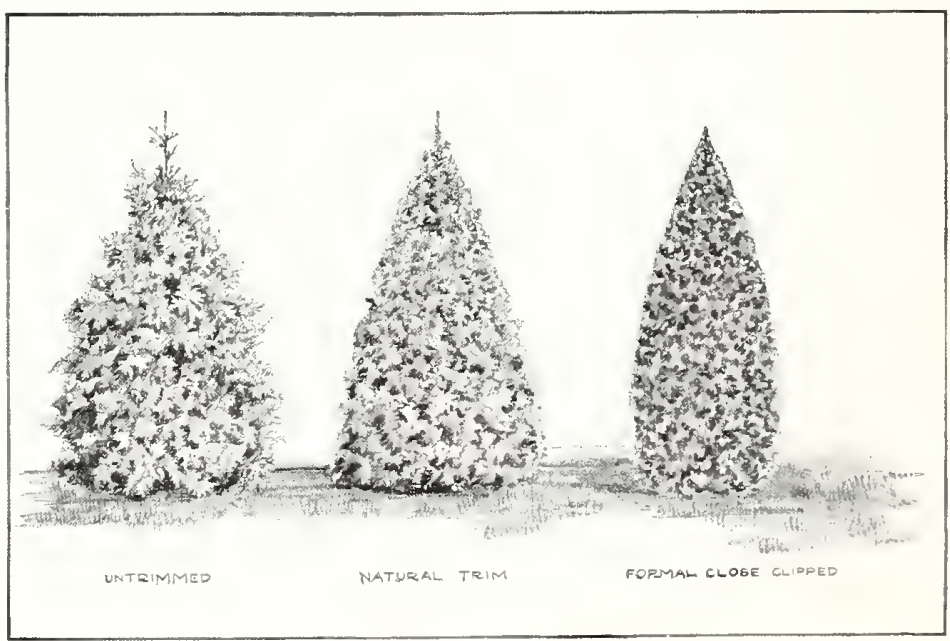




\section{What Voul Ilave Io Work Wirls}

Tall Growing Evargerans Croup. 1

Lustrian Pine Black Hill Spruce Canadia Hemlock. Colorado Blue Spruce Colorado Green Spruce Concolor or White Fir Douglas Fir. .

Norway sipruce

sootch Pine..

White Pine

White Sipruce

\section{Madium IIsight Evergereans} Croup is

American Arborvitae.

Cannart Recleedar

Chinese Juniper

Douglas Golden Arborvitae

Dwarf Alberta spruce

Goldtip Redcedar.

Japanese Yew.

Redcedar.

Schott Redcediar

silver Redcedar

spiny Greek Juniper

Ware Arborvitae (Siberian

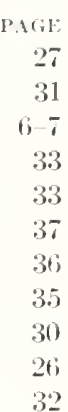

Narrow IPyanuial Evergirates Group C

Colorado Juniper

Column Chinese Juniper (blue

Column Chinese Juniper (green

Doughas Pyramidal Arborvitae

Hill Dundee Juniper.

Hill Prramidal Arborvitae

Ifill silver Juniper

Swedish Juniper.

\section{IRound ar Lilobular Everumans} Group I)

Dwarf Japanese Yew

IIill Mugho Pine.

Nest-Shaped Juniper

Woodward Arborvitae

\section{IIaIf Ereat Evergreans} Group $E$

Andorra Juniper

Golden Prostrate Juniper

Japanese Table Pine

Koster Redcedar

Meyer Juniper

Pfitzer Juniper

P'rostrate Juniper

savin Juniper

Vitse Shaped Prostrate Juniper

Von Ehron Juniper

\section{Creaping Evergurates}

$$
\text { Croup } \mathrm{F}
$$

Bar Harbor Juniper. .

Hill Waukegan Juniper

Japanese Juniper

sargent duniper

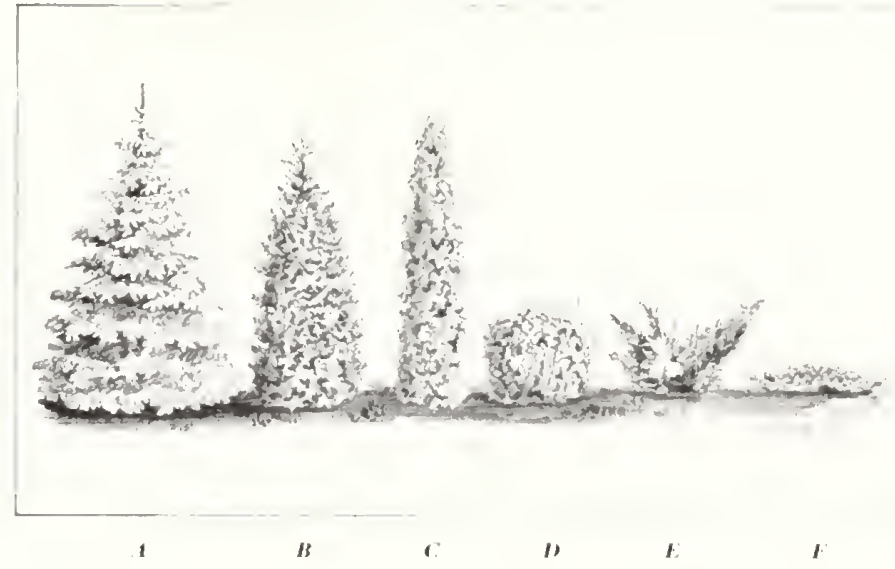

16)

ARIOI'- habits of growth ollatinable in Evergreens are roughly illustrated above. First, determine whether the tree vou have in mind to plant is suitable and will derelop into a specinen of the size ank shape that you want.

\section{riROLP A}

Trees in this group are the largest and tallert growing forms. They inclule varieties which develop into speeimens of ten to fifteen feet in diameter and up to a height of fifty feet or more. They are best suited for such purposes as heavy baekgrounds, screens, windhreaks, forest plantings, and individual speeinens. Planters ver' often use them in other ways, but in (loing so must realize that the trees will eventually beeome large and must be removed. Spruee and pines are frequently used in foundation plantings and while they are attraetive for a number of years in such locations they will in a few years beeme too large and must be taken out. some rarieties can easily le trimmed and kept small.

\section{GRoTP}

The average height of trees in this group will run eight to twenty feet, and in diameter usually not nore than three to five feet. Such trees are suitable for the taller growing speeimens in foundation plantings, entrance groups. also suitable for planting annong horder to add eontrast to flowering shrubs, or formal uses in gardens.

\section{GROTP C}

This gromp eovers trees of extremely narrow pyramidal habit. The narrow habit of trees in thi- group may lie further improved by trimming, but all of them have a tendency to produce very narrow phire-like forms. Sinch trees are of use at entrances for sentinels, also for markers in formal gardens, at rorners of houses, and smilar situations. All of these forms can easily be trimmed and kept small if desired although some of these varieties will reach twelve to fifteen feet or more when matured.

\section{(iRo('P' 1)}

Thede is increasme ueed for round ol ballshaped trees. For use around smaller typen of homes, in foundation plantings, in corners noxt to the walk, and in many situations where "tree forms." would be out of the question. these little dwarf growing trees fill the purpose. They can all be trimmed and kept as small a desired, although if allowed to grow many of these trees will reach a height and diametor of three or four foet.

\section{GROLP]}

Among the half-erect forms we find the finest of all our Evergreens and those which are of greatest use, especially in lankseape planting of small areas. Trees in this gromp include those forms which are exential for the low-growing trees in foundation plantings, entrance plantings, rock gardens, and low-growing groups.

\section{(iROE $\left.{ }^{*}\right)^{\prime}$}

Trees in this group are the low, cresping. mat-like forms that remain wose to the gromed. They grow not wer six or eight inches high under usual conditions and spread to a considerable diameter. Howrver, as they can easily be elipped and trimmed, they remain for years in a small space. Trees in this group are suitahle for rock gardens, to cover terraces or banks, or to finish off a group of taller growing forms.

\section{HILL EVERGREENS Famous since 1855}




\section{Laying Dut the Fonmalation Planting}

$\mathrm{T}$ HE size of the house, the height of the foundation, and the matter of economy are all factor's which govern the number of trees necessary or desirable for a foundation planting. Below is shown four different treatments for the same house.

\section{SIMPLE ENTRA NCE DESIGN}

In planting "A" the simplest possible planting is shown. Merely a tree of tall upright habit on either side of the entrance with a group of one or two low-growing forms around it. Such a simple planting is one which might be all that your house would require and certainly it would make a pleasing design.

\section{ADDITION OF TREES TO CORNERS}

Planting " $B$ " shows the same simple design with the addition of a small group at each corner.

\section{COMPLETE FOUNDATION TREATMENT}

Planting " $\mathrm{C}$ " shows the same planting with the area between corners and the entrance filled in by using low-growing trees beneath the windows.

\section{FOR LARGE IIOMES}

In group "D" where space allows and the house is of a suitable style the planting may be extended to include two rows of Evergreens rounded out both at the entrance and at the corners of the house.

This series of sketches illustrates the evolution of a planting from the simplest form up to the completed heavy type of planting. From the standpoint of economy a planting of this kind may be developed over a period of two or three years. The first year the house could be planted as shown in the first group; the second year a few trees planted, and so on until the planting is completed.

While this plan is here applied only to foundation plantings, the same idea could easily be carried out with any other type of planting around the home grounds.

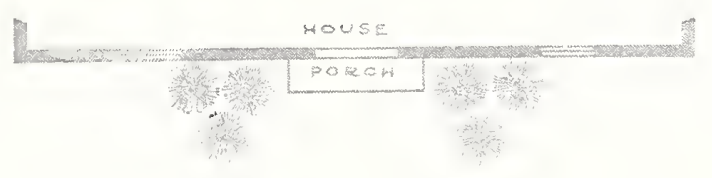

(1) Simple entrance design
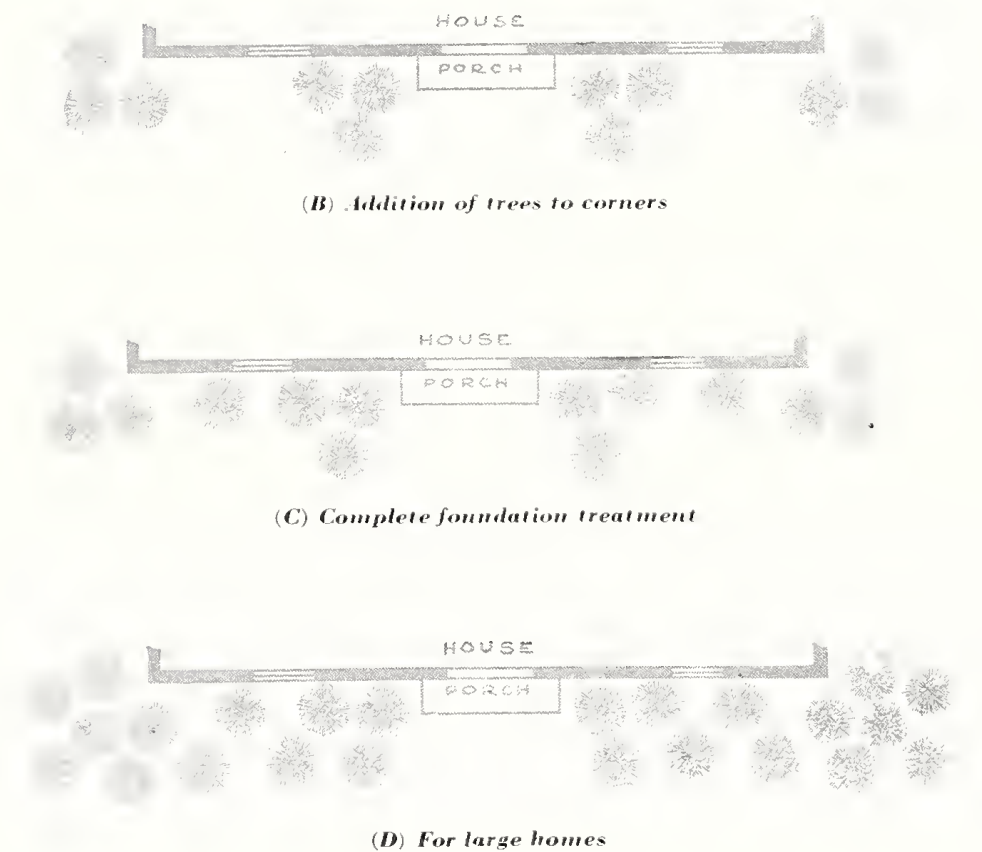

(D) For large homes

\section{Trees for Special Locations}

The Right Tree for the Right Place

7 HE ideal location for most Evergreens is an open, sunny situation removed from city smoke, on well drained soil. When Evergreens are planted under adverse conditions, such as shade, damp ground, or under conditions of the city, some attention ought to be paid to the selection of varieties. It should not be concluded that the trees mentioned will grow only under the conditions named. For instance, trees that endure shade may likewise flourish in the sun, but are mentioned here only for their ability to succeed in the shade. It is also a curious fact that some trees which are valuable for their ability to grow in low, damp ground, will also prove satisfactory in high, dry situations.

\section{Lvergreens That Endure City Atmosphere}

In localities where there is a great deal of smoke and gas in the air, it is important that Evergreens are selected that are able to resist these conditions. There are no Evergreens that can be said to thrive vigorously under conditions mentioned, but the following trees seem to suffer less and prove more satisfactory than most others. Careful attention to planting and the use of good soil is important. Also, wash off foliage frequently with a garden hose.

$$
\begin{array}{ll}
\text { Japanese Yew } & \text { Mugho Pine } \\
\text { Dwarf Japanese Yew } & \text { Scotch Pine } \\
\text { Austrian Pine } & \text { Colorado Blue Spruce }
\end{array}
$$

\section{Wvergieens That Will Endure Hot, Dry Situatioms}

The following trees are drought resistant because they are deeprooted. Watering should be done, however, until the trees are established.

$\begin{array}{ll}\text { Redcedar } & \text { Pfitzer Juniper } \\ \text { Scotch Pine } & \text { Chinese Juniper } \\ \text { Mugho Pine } & \text { Prostrate Juniper } \\ \text { Savin Juniper } & \text { Japanese Juniper }\end{array}$

\section{Evergreens That Will Endure a Shallow Soil}

Plantings are sometimes necessary in locations where the soil is not deep, perhaps with rock not far under the surface. In such a location, the following trees are suggested:

$$
\begin{array}{ll}
\text { Norway Spruce } & \text { Scotch Pine } \\
\text { American Arborvitae } & \text { Hemlock } \\
\text { Redcedar } &
\end{array}
$$

Wvergreens That Will Endure Severe Cold

In localities where the winter temperature reaches low extremes, the use of Evergreens must be confined to the hardier sorts, including the following:
Black Hill Spruce
White Spruce
Colorado Blue Spruce
Redcedar
Nugho Pine
Pfitzer Juniper

\section{Evergreens That Will Endure Shate}

While most of the following varieties will grow even better in sunlight, they will also survive fairly well in the shade.

$\begin{array}{ll}\text { Japanese Yew } & \text { Hemlock } \\ \text { Dwarf Japanese Yew } & \text { Pfitzer Juniper } \\ \text { Prostrate Juniper } & \end{array}$

\section{Evergreens for Terraces, Sandy Ibanks, or for Ground Covers}

It is sometimes a problem in landscaping to cover a hillside, a steep terrace, or even a level area where grass does not grow or where a low ground cover is desired. Among Evergreens especially suitable for such work are the following:

$\begin{array}{ll}\text { Japanese Spurge } & \text { Waukegan Juniper } \\ \text { Prostrate Juniper } & \text { Koster Redcedar } \\ \text { Andorra Juniper } & \text { Japanese Juniper } \\ \text { Bar Harbor Juniper } & \text { Sargent Juniper }\end{array}$

\section{Wvergiecens for Use in Itock Gardens, Around} Pools and Small Thockeries Duarf Creeping I'arielies

$\begin{array}{ll}\text { Hill Waukegan Juniper } & \text { Bar Harbor Juniper } \\ \text { Japanese Juniper } & \text { Sargent Juniper }\end{array}$

One point about the use of Evergreens in rock gardens cannot be oreremphasized. Planters should start with small-sized trees and keep continually trimming and pruming the trees so they will not grow too large. 


\section{Tha Wromg Way do IPlam}

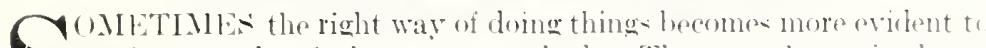
D us by a study of the wrong methods. The same home is shown Where in two plantings, one with a poor plaring of trees anch wrong selections of types and the other with careful arrangement and proper selections of varieties.

In the pieture below approximately the same number of trees have heen used, but the re-ult can be neither permanent nor attractive. In this planting are varieties with wire spreaching branches entirely unsinted to planting near the house in a foundation setting. It the entrance are two low-growing varieties which haw heen replaced with tall narrow ones illu-trated in the picture at the right. Sou do not need to be a landscape architect to see that these trees are much more appropriate for this particular location than thone of fow -prearling habit.

In the pieture below, out in the lawn, is a Juniper of slender branched pyramidal form. Trees of this type seldom, if ever, should be used as specimens. In the right hand picture is a specimen sprues tree, a type of growth which is suitahlo for an inclividual specimen of tree

It is, of course, unnecessary to use the exact varieties shown in the pieture to the right. but in solecting the trees the solections ought to be confined to trees of similar growing habit

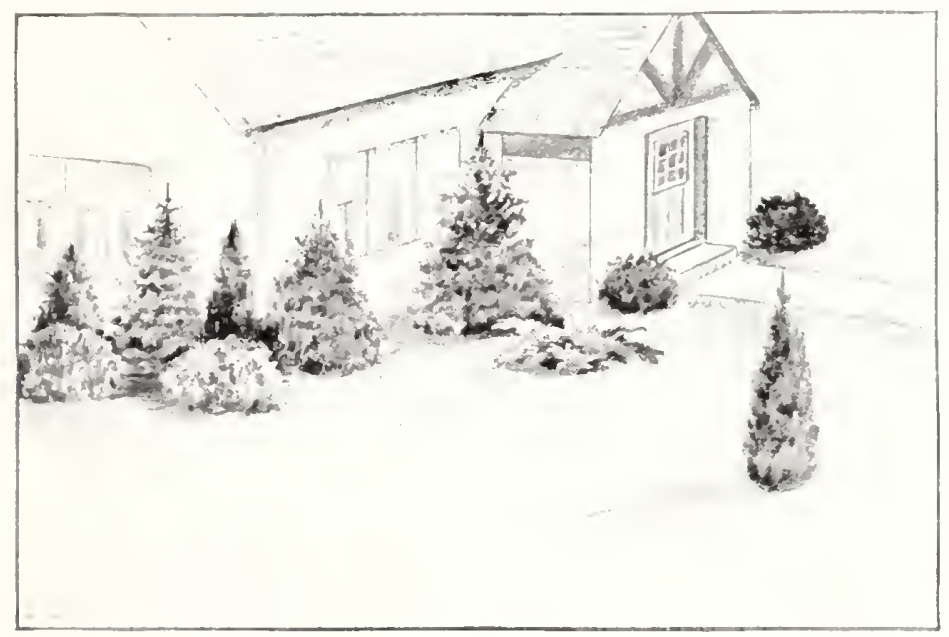

\section{Dhjorer of IDamting}

MHERE are numerous purposen to be aremplised by planting To be sure, we generatly plant because "it makes the place low good," but there are other reas on for planting. Amone the mont popular uses of Erergerens are

\section{Foundation phating.}

To adt points of interest in the rock garten

To bring out points of alceent in the grounds

To form a background or screen against unsightly views

To form a low barrier or hecke

To form a protection against winks, or

A tree to be planted for its indivikual, ornamental beiluts.

Therefore, before planting go over your grounds and decide ju-t where if po-ible, and for what purpone the planting is to be made.

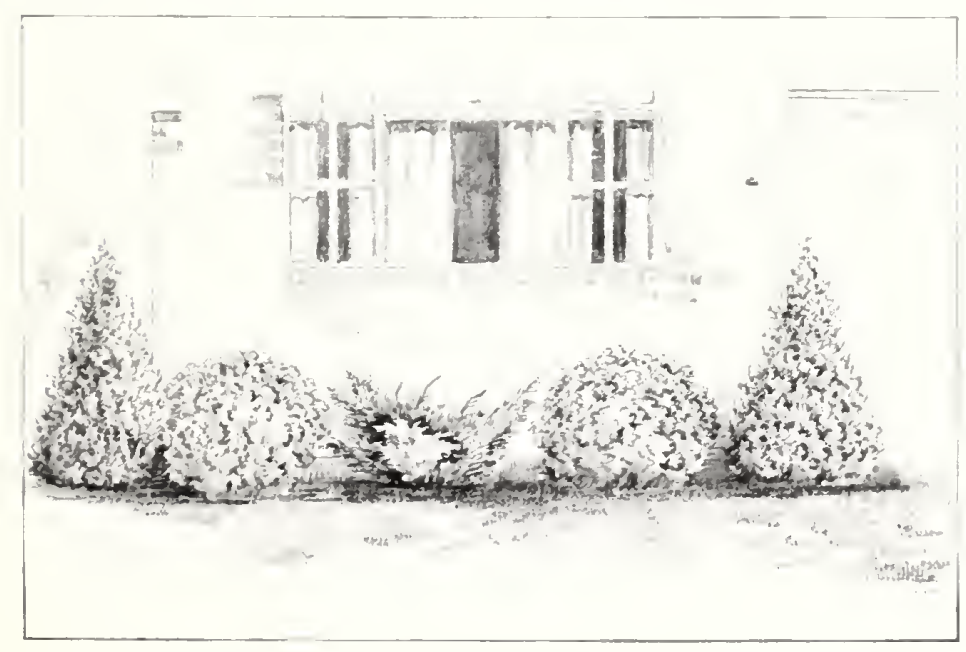

I Goud lolanting Irrangeruant
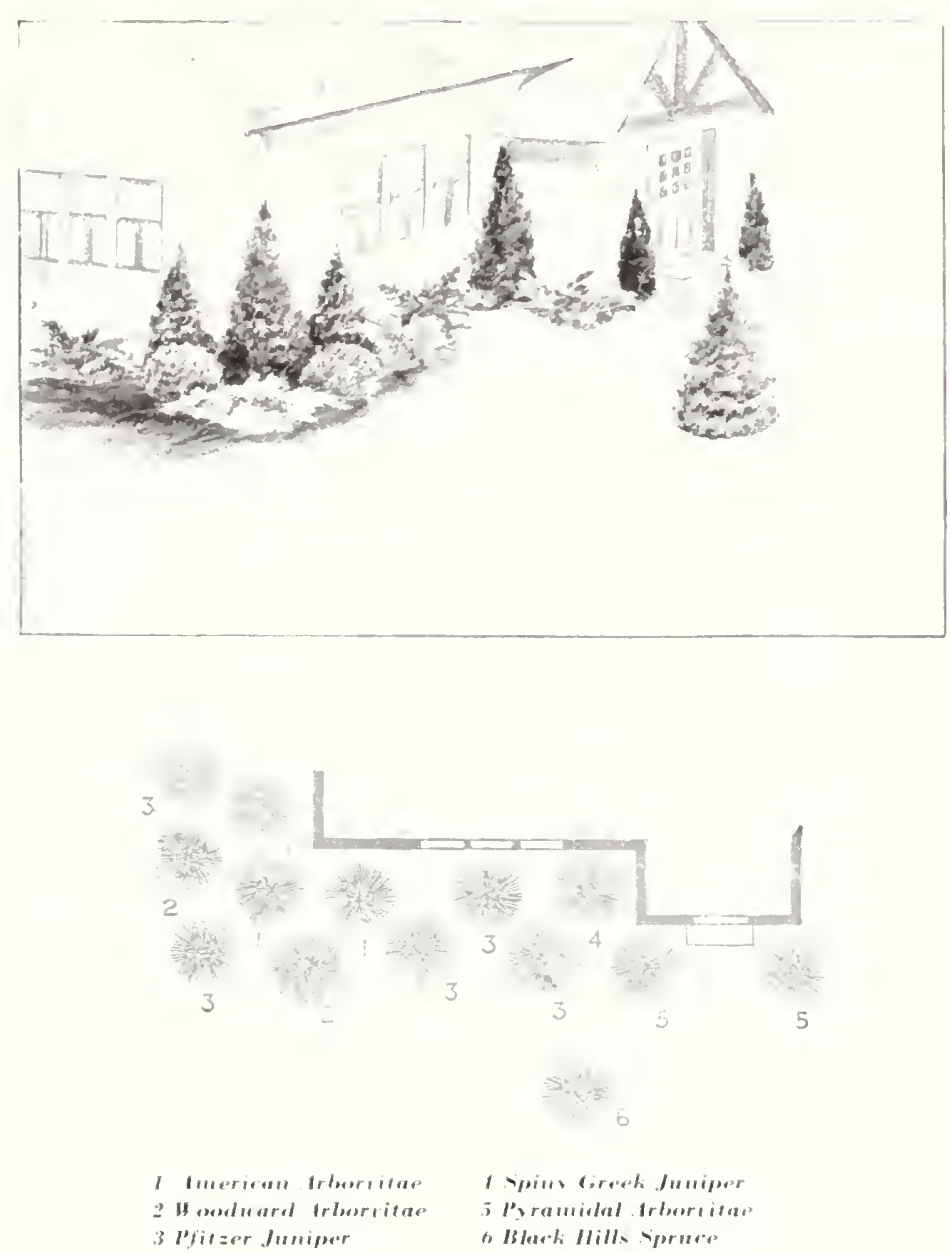

\section{Varration in IIteight al I'oint (1) Consialare}

$\mathrm{T}$ Wo plantine plane for the same spare are ithe-traterl below. The arrangement pietured at the right is the one which the himbeape arehitect would recomment. This planting has a varlation in height which give it a more artiotie finish and which the eye witl readily recognize as an imbrovenent orer the pireture at the left. The trees in this planting are not wet in one straight hine, but the two Junipers are - paed sightly in front of the others, giring the whole an appearance which should serve as an example of artistie treatment. The phanting

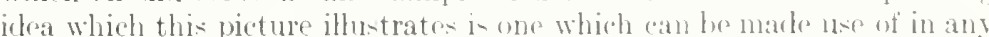

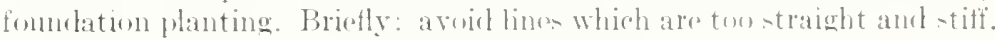
Give as mueh rariation to the height as powilde.

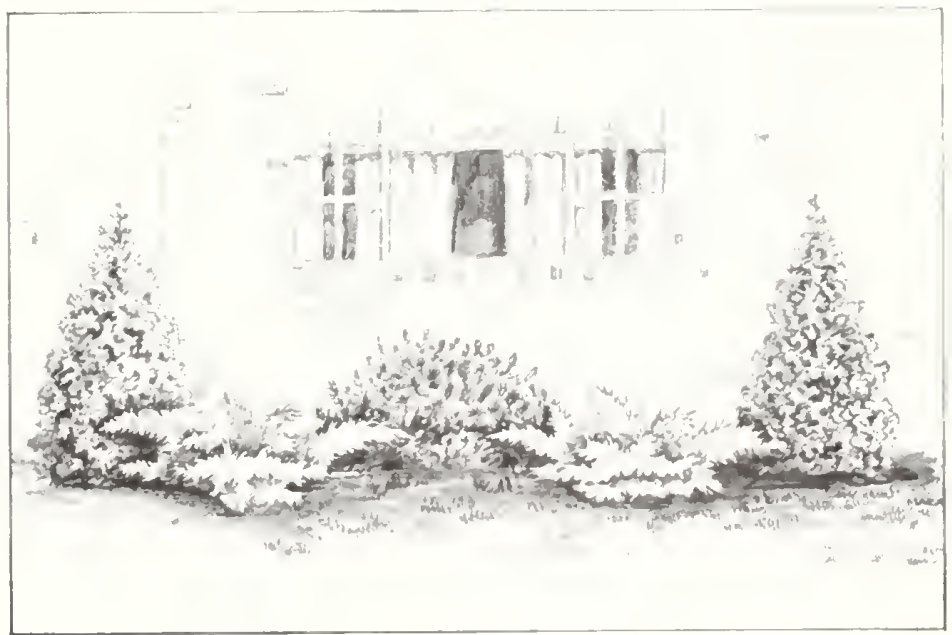




\section{Transplanting Season}

Best Time to Plant

F OR fear of being contradicted by experienced planters, we acknowledge that under favorable conditions it is possible to transplant Evergrcens any day during the year. We do not wish to advocate such a plan, especially with trees taken up and shipped. On the other hand, where small or medium sized trees are to be mercly transplanted to a different part of the grounds, the transplanting can be successfully done almost any time except during the very hottest days of the summer.

From the practical standpoint, there are only two safe seasons to plant Evergreens-a few weeks in the Spring and a few weeks in the Fall. We are speaking now of conditions in the north central states. For planters who live in Florida, California or other localities where the seasons are not so well defined as they are here in Illinois, planting time may continue from late in the Fall until February or March in the Spring.

\section{SPRING PLANTING SEASON}

In the latitude of Chicago, it is usually the first of April before the ground is in condition to plant Evergrcens in the Spring. Some ycars, we are able to plant the last of March and again the season may not open until later. On the whole, however, we can say from the first of April until the 15th of May is the proper time to plant Evergreens in this locality.

Spring has always been the favorite time for transplanting. At that time of the year our thoughts turn to the out-doors and therc is more interest in planting then than at other times during the year.

\section{FALL PLANTING SEASON}

On the other hand, Fall planting has many fine advantages. More and more people are taking advantage of the long Fall season to transplant and to rearrange their grounds. Experienced help is usually available, the weather is more settled and planters find morc leisure in the Fall. The Fall planting scason usually opens about the middle of September and continues until the ground freezes, usually about December first. Fall-planted trees should be planted during late September or early October for best results and this is the season which we recommend. In our own transplantings here in the nursery we are usually able to continue up until the first of December and sometimes even later, depending upon the weather.

After all, it is not so much a matter of when to plant as the manner in which the planting is done and the conditions the planting is made under. A few rules for transplanting which are given elscwhere in this catalog are more important than the exact time for doing the work. It is a good plan, however, to kecp the planting within the periods recommended above.

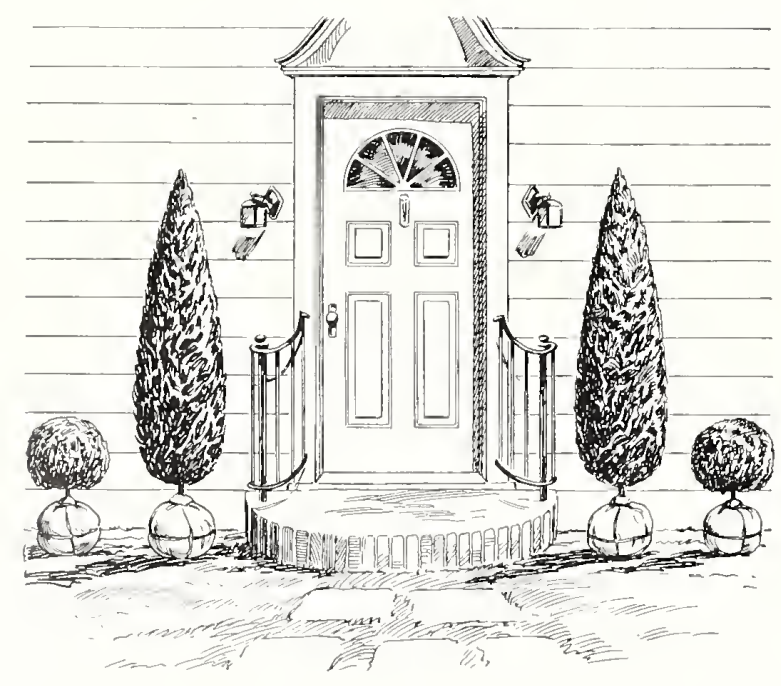

Before digging holes it is a good plan to arrange the trees in position. Sometimes in this way an improvement in arrangement will suggest itsclf. Move the trces around until the most attractive setting is arrived at.

\section{PLA N T I N G A N I}

\section{Planding Halled and Burlapped Evergreens}

"DALLED and burlapped" means that the tree is dug from the nursery soil with the earth remaining undisturbed about the roots of the tree. The earth ball is securely wrapped in burlap and tied with stout rope. The tops of all except the small trees are tied up to prevent injury to the branches. This method practically insures safe handling and very little shock to the tree in moving.

Be sure to set the boxes out of sun and wind.

It is advisable to plant your Evergreens as soon as they are received. If impossible to do this, they will keep for several days in good condition if earth balls are kept wet. If unable to plant at once, submerge each earth ball in a tub of water for a few minutes. Then stand the trees in a place out of the wind.

Leave the limbs tied up and the burlap on the roots until after the trees are planted.

Dig the holes wide and deep enough easily to admit the earth ball. Set the tree straight and two inches deeper than it stood in the Nursery. (You can tell by the soil line on the stem.)

Tamp the dirt in firmly, bearing your whole weight to pack it in tight. Lcave the burlap around the earth ball, but cut the string and lay back the burlap as shown in sketch. (The burlap helps to anchor the tree and soon rots away.) When the hole is two-thirds filled, flood with water and then draw in enough loose dirt to mound up the hole and form a mulch.

After the tree is planted, unwind the string from top and carefully straighten out the branches.

Watering: At time of planting and once each week during the first season, give a good thorough soaking of water to supply ample moisture for the roots to feed on and prevent foliage from drying out.

Mulching: The best way to mulch Evergreens is to apply a covering six or eight inches deep of manure, leaves or straw on the ground around the tree, late in the Fall after ground freezes and then spade this into the top soil in the Spring. Never put stable manure in the holes when planting.

\section{A Word About Soil}

I $\mathrm{T}$ is not surprising to find so little accurate information in the mind of the average person regarding soil. Most plantings of Evergreens are made without any serious consideration of the chemical and mechanical condition and contents of the soil. It is not neccssary that we become soil technologists in order to succeed with our trees. In instances where trees are planted to insure their long life as specimens and for best development over a long period of years, some attention to soil conditions will prove a great benefit.

On the other hand, plantings of trees around the home grounds for ornamental use need not concern planters to any extent, as such plantings are intended for a few years' use with no thought in view of establishing plants which will endure for generations.

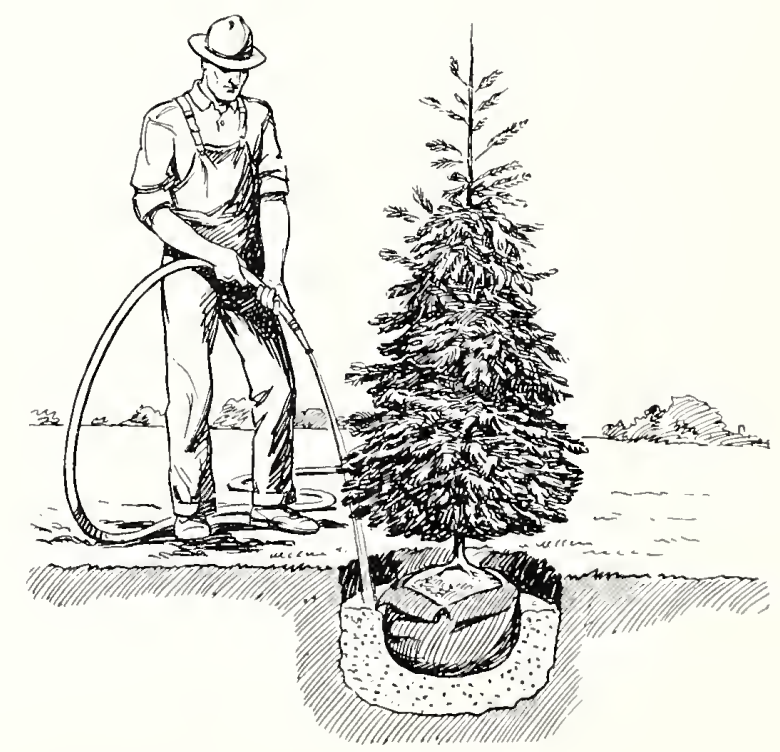




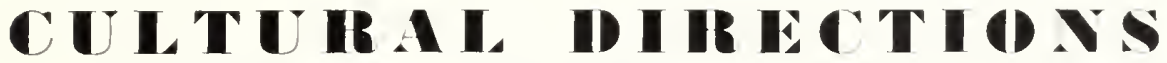

\section{Fertilizers for Evergiresems}

W

HAT about fertilizers?" is a daily quention from planters of Evergreens, who are anxious for good thrifty trees.

Fertilizer applied to Evergreens indiscriminately, with no thought of its physical properties or its strength, is the cause of many a disappointing failure of the trees.

The abundant use of fertilizer is not the panacea for all ills of Everwreennor will its use overeome an unfarorable planting location, a lack of watering or neglect of cultivation. There things are all more important than the fine points of chemistry concerning the value of certain material. used as fertilizers.

One thing to learn in handling Evergreens is to avoid placing any fortilizer in direct contact with the roots. The most conmon practice is to apply the fertilizer on top of the ground and allow it to be carried down with the rains, although if thoroughly mixed with the soil at time of planting, fertilizer can be applied in this way.

It is possible to "kill Evergreens with kindness." One planter brought his problem to us recently and his experiences could be related for the benefit of other planters. Hir entire planting of Evergreens died after he had given them the "very best of eare." First he dug out all the coil where his planting was put in, and filled in with black dirt secured from a nearby greenhouse. This was very rich soil to begin with. Then he mixed bone meal with it. Then he gave a generous application of a well known commercial fertilizer. It was to rich a diet and his trees could not survive it. If this planter had merely used his black dirt and no fertilizer, or used his regular wil with a light treatment witl plant food of some kind, his trees would have been alive and healthy.

We have terted commercial fertilizers and can recommend both Armour's Tree Food and swift's Vigoro. Either of these product is easily available. ['se them according to the manufacturer's reconmondation.

\section{Suggestions for Wamarimg}

$\mathrm{T}$

YHERE are those who adrocate no watering at all and on the other extreme those who recommend far more watering than is necesary.

Very few Evergreens die from ton much water. Those that fail to grow from lack of water probably account for the greatent number of failures in Evergreens.

The thing to bear in mind in watering Evergreens is this: see that the roots are kept moist. There is no ruke which we can lay down that will guarantee this result, as can well be seen. In the first place, the amount of rainfall which may normatly be depended upon in many localities, the condition of the soil, that is, whether it is a type of soil that retains moisture or not, and the amount of cultivation which is given, all have a bearing on results.

It is also quite evichent that after the trees become better established and the roots extend down into the soil, they become more independent of surface moisture and can withstand considerable trought.

In the north central states, the months of June, July, August and september is the perion of the year when vegetation requires artificial means for watering. When watering becomes a necesity do not water every day, but at intervals of a week or ten days. A thorougla soaking twice a montla is far more beneficial than a daily sprinkling of the top soil. I small amount of water applied directly on top of the ground is liable to cause the roots to grow upward to seek this small amount of moisture rather than downward as they should when thoroughly soaked.

\section{WTERIVG THE TOP OF EVERGREETS}

It is beneficial to Evergreens oceasionally to give their tops a thorough washing off with a garden hose. This removes dust and grime and helps the trees to function in a natural way. In dusty or moliy locations this is important. Judgment must be used in watering the tops of Evergreenw, to do it in the evening or late afternoon or a day when there is no bright sun. Watering in the heat of the day may sometimes hurn the foliage.

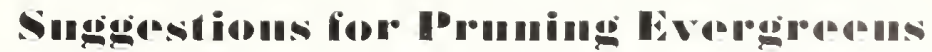

$\mathrm{T}$

() paraphrase an old saying we might say. "spare the knife and spoil the tree." But we must not take this too literally. We have all seen plantings of Everoreens that have been rumed hy someone who has a mania for trimming. Every tree, regardles of it natural habit has been trimmed after the same pattern. This produces an artifieial and lispleasing appearance and entirely ruins the beauty of the troe as nature intended it to grow:

In contrast to this type of pruning we sere a planting which has been entirely neglected. Tresesometimes lecome "leggy," irregular, weak anel thinned in appearanee, anch if alkowed to go without attention soon fail entirely to fill the place in the planting for which they wore originall! intended. Between these two extremes is a rasonable midelle course

Rules tor proning Evergerens are langeroms unless tempered with the judgment of him who is doing the proming. This is apparent when we realize that no two trees are alike. Fach plant has individnal characteristies, fome are by nature conieal, some columnar, some globular and some prostrate. siggestions must theroutore les only sugene-tions and not definite iron-clad rules to be followed withont variation.

You must first decide the purpose for pruning. Rabsons for pruniner may be roughly deceribed ac follows

To invigorate the troe.

To keep the tree within rertain linits as to size and shape.

To remove any disased or injures part of the tres.

To facilitate transplanting.

To shape the tree into some desired form.

In the case of Pines, lirs and sinences or other vareties of similar growth, the process of pruning by "pinching off" the buck can be followed to check the growth of the more vigorous branches and to holp the tres develop into a more perfect specimen. When the new erowth is coming out in the spring the more vigorons buds can bra pinehed oft either in whole or in lart to give the weaker buds a chanee to push out and equalize the growth. If this pinching of the buds is done carefully, the new growth the following season will come out just as straight as though thic pruning lad not been done. On the cofter foliage plants, the huck are not so eomsprenous, so pruning ("an be done with a knife, to the sanne effect.

\section{Cultivation}

C LLTIVITHA is the one most important point to remember in the culture of Evergreens. Planters ale sometimes negligent in cultivation and fail to do any thing alout it until their trees start to show signs of neglect. It is a uood plan to start cultivation immediately after planting. Keep the ground in a cultivated state around newy planted trees. This conserves the mojsture in the ground and provents raporation, keeps the grasis and weeds from interfering with the growth and improves the appearance of your planting wonderfully. Cultivation is especially important where the ground is naturally hard and easily dried out. The drier the -rason, the greater the necesity for cultivation. some planters make the mistake of mulching their newly planted Frergreens to avoid the work of eultivation. A muleh is better than no antivation at all hut cannot take the place of thorough eultivating.

The "dust muleh" is especially nexescary with lvergreens. IBy "dust mulch" is meant a layer of loose carth, threo or four inches despe made by weekly -timing of the soil with a hoe, all thomele the smmer months. from the maddle of $M$ ay to the tirst of september. This prevents baking and cracking of the soil and the eseape of moisture. In the case of small tress planted in beds or nursery rows, enltivation is just as eserntial.

\section{Winter moorention}

I

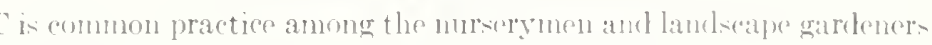

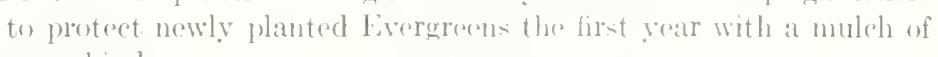
solne kind.

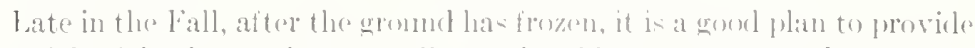

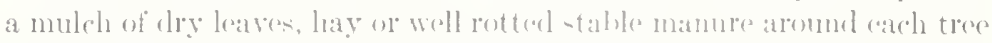

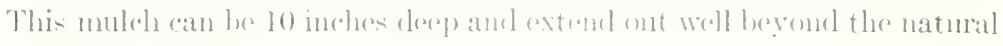
sproacl of the routs. 


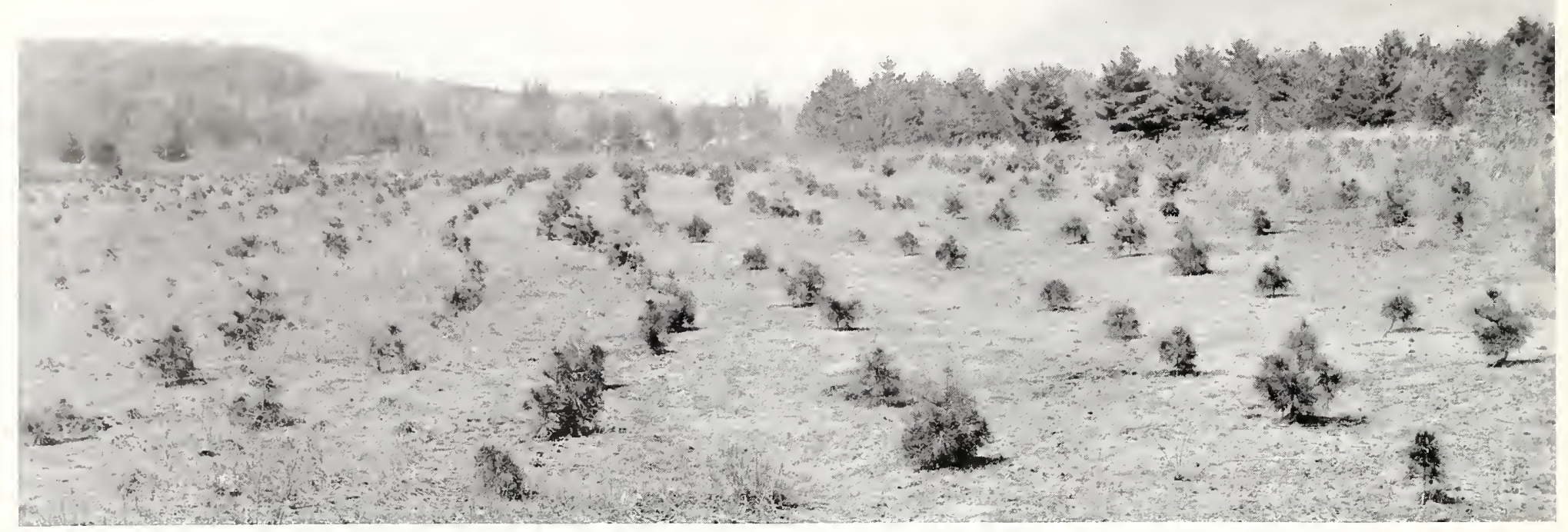

A plantation of pines tho yeurs after planting

\section{Help to IBring Back the Forest?}

$\mathrm{T}$

HE growing of trees as a profitable crop is a practice that has been followed for many years by the federal government and the various states. Large privately owned industries with far seeing management and individuals with wastelands have been carrying on systematic reforestation in increasing numbers. Aside from the actual profit to be gained, reforesting has a much greater economic aspect. Many organizations and prominent men have devoted ceaseless effort for years past to arouse public interest in the preservation and systematic use of existing forests and the planting of trees for future generations.

European countries much older than ours in point of settlement have stringent laws relating to the cutting of trees and the planting of new forests.

It has been the business of the Hill Nursery to furnish Evergreen trees for reforestation for the past fifty years. Millions of trees have been planted which were grown in this nursery. Trees for forest planting are available at a most reasonable cost when used in large quantities, and even in small plantings the expense is remarkably little.

Lands unsuited to any other use generally are made to produce trees. Worn out agricultural lands, sand dunes and barrens, and cut over timber lands offer fine opportunities for forest planting. Planting the water sheds to conserve the nation's water supply is increasingly receiving the attention of municipalities. Owners of private estates and farms can erect no more lasting monument to their sound judgment and leave a heritage of genuine worth to their successors.
The actual work of planting is simple and can be done readily by anyone. The planting is best clone by two men, one with a grub hoe to make holes, and the other with a pail of trees. The trees should be set about six feet apalt each way, which will require about 1200 trees per acre.

Preparation of the soil is not necessary but the plantation must be protected from fire and grazing must be prohibited. In five to ten years, or before if possible, the brush, weeds, and rubbish should be cut out, but further attention is not necessary until the trees have reached twenty years of age. Then the advice of a forester should be sought. Thinning and any trimming will have to be looked after depending upon the soil conditions, the rate of growth and the varieties being grown. Twenty-five to fifty years makes marketable timber and plantations should produce $\$ 150$ to $\$ 200$ or more per acre, total income.

\section{SELECTION OF VARIETIES}

For light sand, Scotch Pine is a satisfactory tree. For coarse gravel, Red Pine is recommended. In wet lands Balsam Fir and American Arborvitae may be used. In good loam soil, White Pine, various Spruces and Larch are suitable. We will gladly offer advice on selections of varieties and also quote prices on large quantities of trees. In small lots prices are given for trees of different varieties and sizes on pages 48 to 51 .

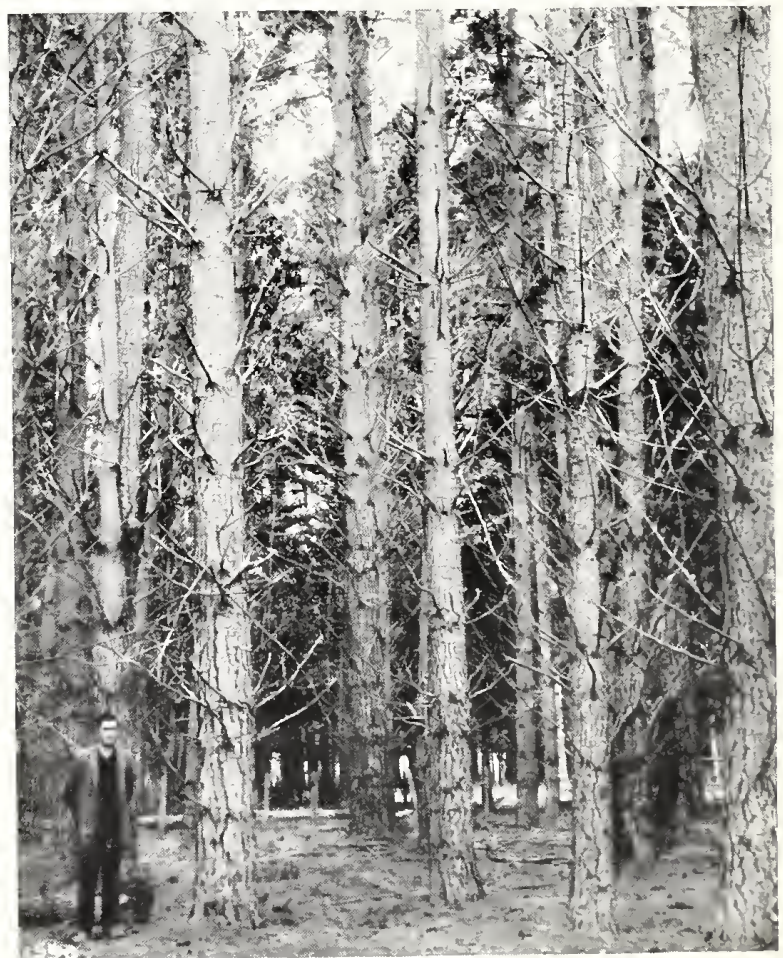

t ment has been in New Zealand. The New Zealand gor 


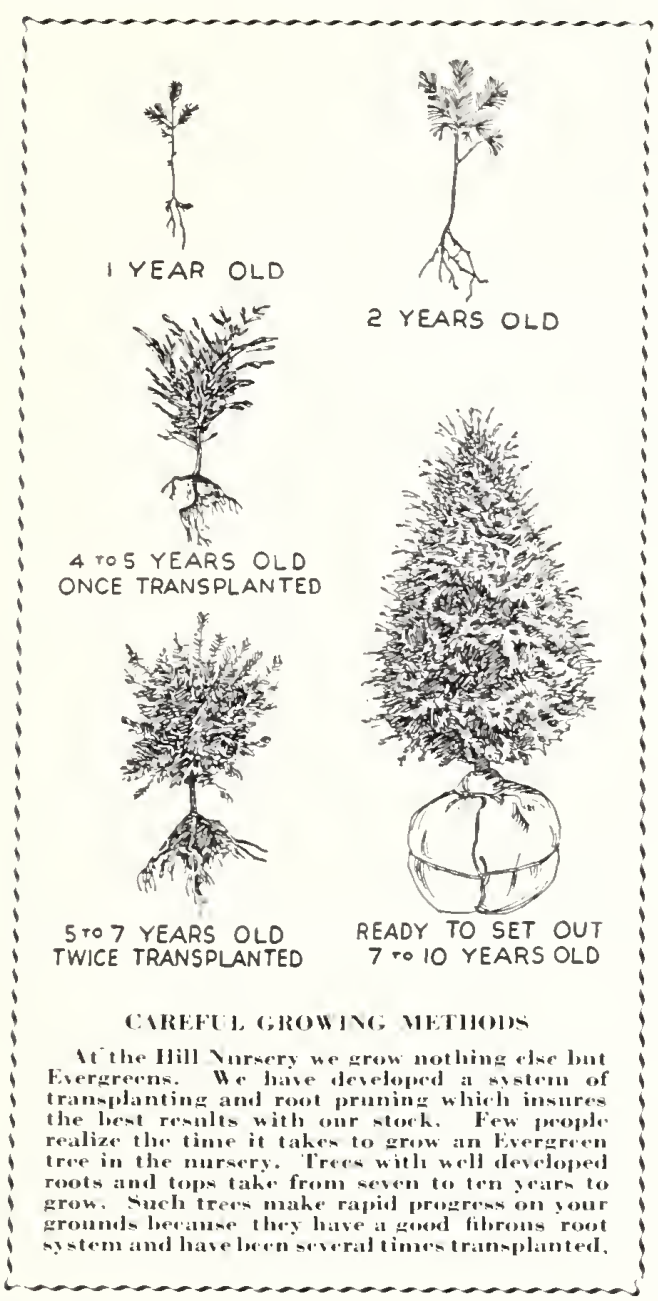

\section{Trems and Information}

MR I, IRINTEE

W

E guaranter that all gools purchised from us will be as repreanted, true to nane, and prove entirely sitifactory upon arrival. We elo not guarantese the trees to grow: Where conditions warrant we will make replacements at one-lalf pricer.

\section{IIJISTIEN}

Iny errors or omisimas in the filling of the orders will be satisfactorily adjusterl if we are notified promptly upen reseipt of shipment.

\section{"IIE. 'TO PIINT IILI, EIERGRELI-}

syming serform: Aloout April lot until May 15th, depending upon weatlee onelitions Fall sefsem: From the middle of soptemulere until the ground freezes, usually in late Novenher. For detailed information on the planting season see page 60.

\section{PRICE-}

Prices in this eatalog are not except casl discounts as indicated below. There are no charges for packing or delivery to the railroad -tation. This catalog cancels all previons catalogs and price lists. Prices are subject to change without notice.

\section{DELIVERY CIIVRGES}

The prices quoted in this catalog are the pries for the trees Fo.B. Dundee. Freight or express charges are at chatomer's expense. In the alsence of elefinite shipping instructions: we will une our best furlgment, shipping hy pareer post, expres or fredght. Sinall trees not billad and burlapped melally ean be sent ly expres. Balled and lurlapped stock ran be shipped

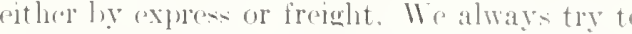

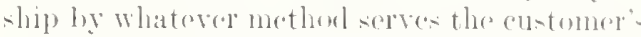
interent best. Arrangemente may alos) le mate to deliver loy truck at reasonable expenos to

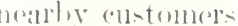

R ITLC

Five trees of the same variety and wize will l, furnislaed at the 10 rate, ofo of the same variets and -ize at the 100 rate, 2.50 of the same variety ancl-ize at the 10000 rate

\section{TERMA OF POIMUT CISII WITH ORIDER}

To induen arly urlers we offer tha following ca-le diseounts for orders mailed in advanee of the shipping - aratom.

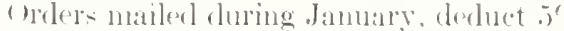
brders mailed during Fobruary, doduet $t^{\prime}$ crder- mailed during . Marend, doduet $3^{\prime}$

wrders mailed during A turil or May, not, no discomint

\section{() R RESP(DSIBILIT)}

In case of any error on our part, it is mut ually

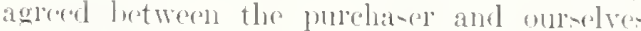
that we shall not at any time ho heeld respensilile for a greater amomint than the original pries of gookt, and orders are aceepted with this under-tamling.

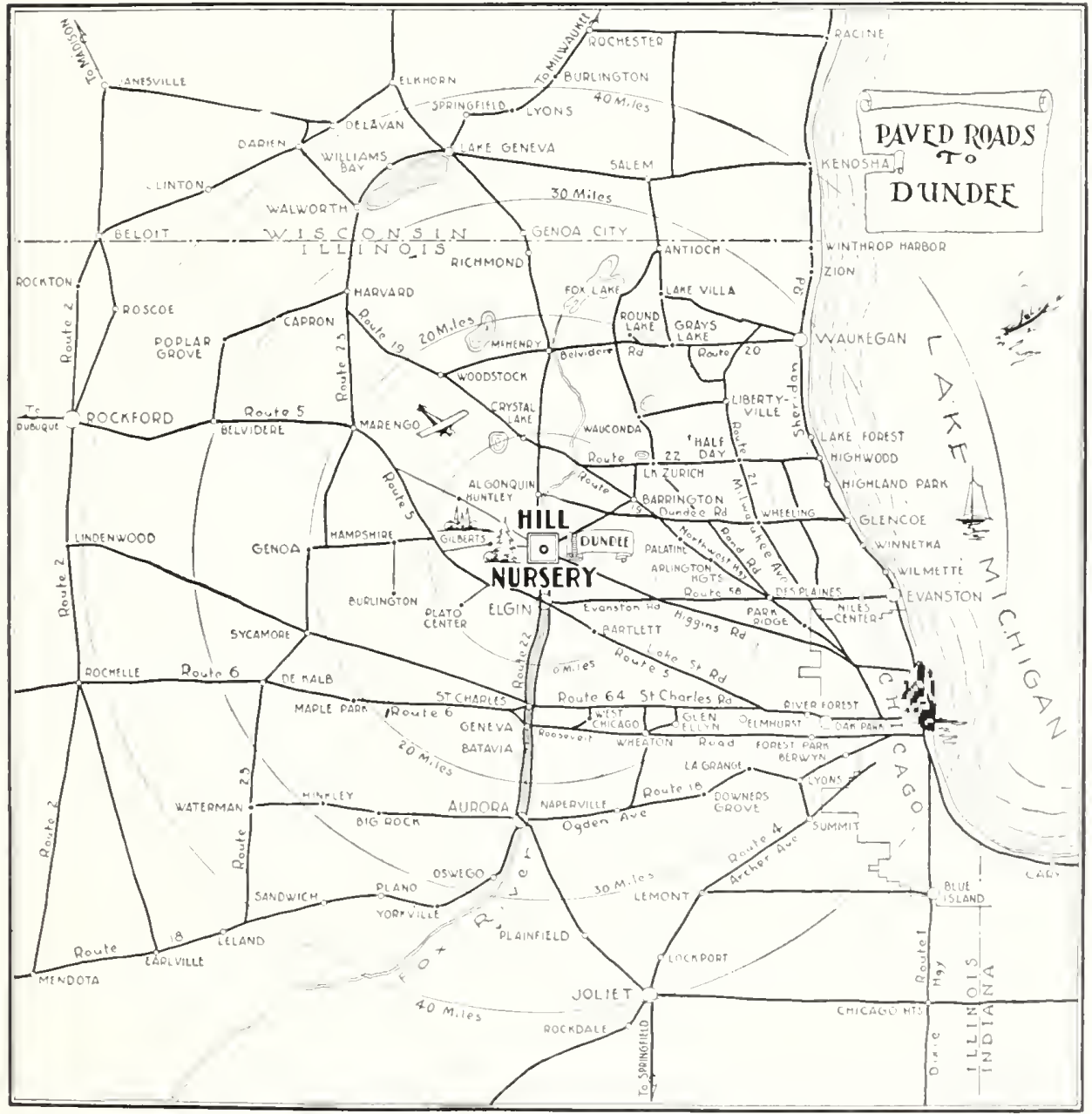

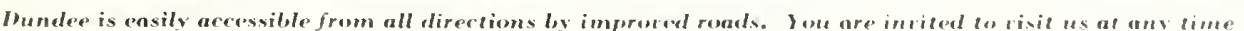

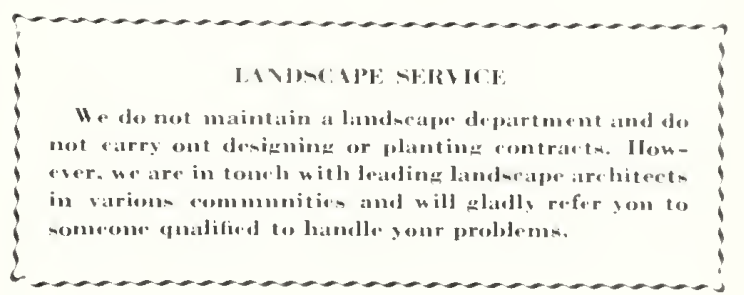

W

E invite you to visit Amoriea's laremet Evorgreen nursery at loundee. During the shipping seasons, a large display of treen idug fresh daily and is available for you to take lome. Sou will enjoy the trip whether you huy or not sizes and prices to suit everyone. Open sundayduring the -hipping seavon.

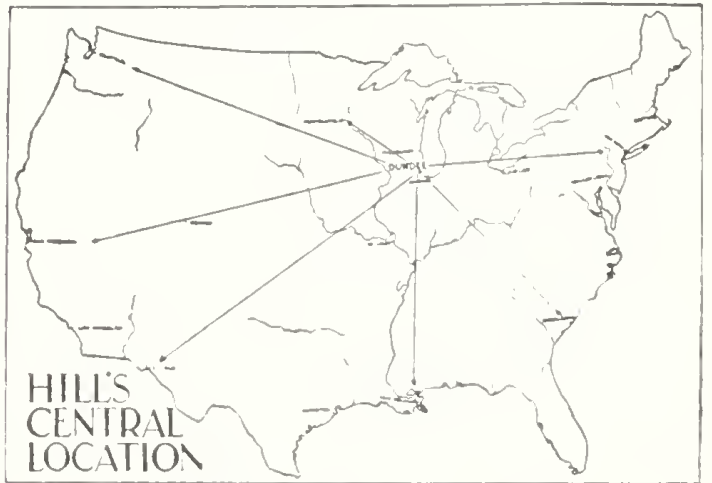

OLR C LCTRUL LOC ITIO)

Being locaterl chene to chicago, the ereat lailway center, gives us direet commection with all leading railroaks. In most eases, Evergreens dug with eartls ball are -hipued by freight. 


\section{CATALAG CONTENTS}

\section{ARBORVITAES}

American Arborvitae.

PAGE

Douglas Golden Arborvitae

Douglas Pyramidal Arborvitae

Hill Pyramidal Arborvitae.

Ware Arborvitae (Siberian).

Woodward Arborvitae.

\section{FIRS}

Concolor Fir.

Douglas Fir . .

\section{HEMLOCK}

Canada Hemlock.

\section{JUNIPERS}

Andorra Juniper.

Bar Harbor Juniper

Blue Moon Juniper.

Cannart Redcedar (Juniper)

Chinese Juniper .

Colorado Juniper .

Column Chinese Juniper .

Golden Prostrate Juniper .

Goldtip Redcedar (Juniper)

Hill Dundee Juniper.

Hill Silver Juniper.

Hill Waukegan Juniper....

Japanese Juniper .

Koster Juniper.

Meyer Juniper .

Moonlight Juniper

Pfitzer Juniper. .

Prostrate Juniper.

Redcedar (Juniper)

Sargent Juniper .

Savin Juniper.

Schott Redcedar (Juniper)......
Silver Redecdar (Juniper) . ................... PAGE

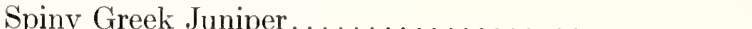

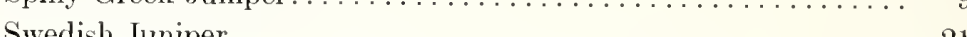

.

Vase Shaped Prostrate Juniper.................... 13

Von Ehron Juniper......................... 21

\section{PINES}

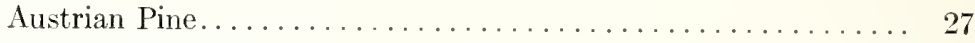

Japanese Table Pine......................... 30

Mugho Pine ............................. 28-29

Scoteh Pine............................ 30

White Pine ............................. 26

\section{SPRUCES}

American Whitc Spruce......................... 32

Black Hill Spruce. . . . . . . . . . . . . . . . . . . 31

Colorado Blue Spruce. . . . . . . . . . . . . . . . . . . . . 33

Colorado Green Spruce............................ 33

Dwarf Alberta Spruce......................... 34

Nest Shape Juniper (Nidiformis) . . . . . . . . . . . . . . . 34

Norway Spruce.......................... 35

\section{YEWS}

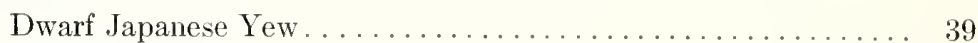

Japanese Yew................................. 38

Evergreen Grafts............................. 49

Evergreen Hedges.......................... 46

Evergreen Scedlings........................... 48

Evergreens for Tubs........................... 47

Illustrations of Foliage. . . . . . . . . . . . . . . . . 5

Japanese Spurge.............................. 45

Once and Twice Transplanted Evergreens...............50-51

Planting and Cultural Directions..................60-61

Profits in Raising Christmas Trees.................. 35

Rock Gardens............................52-55

Simple Lessons in the Use of Evergreens . . . . . . . . . . . . . .56-59

Window Box Evergreens......................... 47

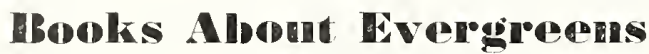

Address the Book Department

D. HILL NURSERY COMPANY

DUNDEE, ILLINOIS

\section{"Wllaraly Evergireens"}

by Frank A. Schrepfer. Postpaid $-\$ \mathbf{I} .35$

This is a new book, written in a very practical way so that it contains a great deal of valuable information. It is described as a practical handbook on Evergrecns, exclusive of the broad-leaved specics.

\section{"Cultivated Everaineens"}

by L. H. Bailey. Postpaid $-\$ 3.00$

One of the few books on conifers. Includes information on landscape gardening, propagation, cultivation and adaptation for different sections, as well as a description of insects, diseases and injuries. 434 pages.

\section{"Wionguation lPanting"}

by Leonard H. Johnson- $\$ 3.50$

The finest work yet published covering the use of Evergrecns for foundation work. 256 pages, contains hundreds of illustrations and helpful suggestions.

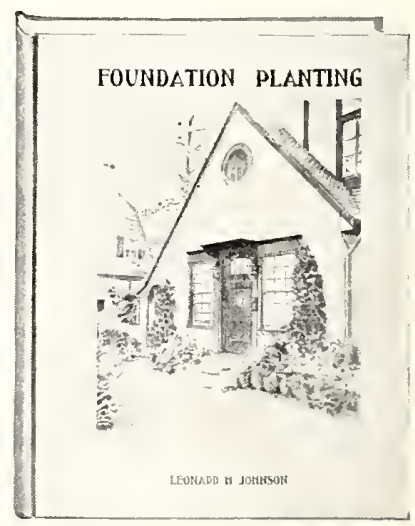

\section{"Conifer Comments"}

is the title of a 70-page booklet containing practical information about culture of Evergreens, prepared by the D. Hill Nursery Company. Sent upon receipt of 10 cents in stamps to cover cost of mailing.

\section{"Evergireens for the Small IPlacee"}

by F. F. Rockwell. Postpaid-\$I.I5

A new book, exceptionally well prepared and containing valuable material. Everyone interested in Evergrecns should obtain this book. 


\section{ORDER SHEET \\ D. HILL NURSERY CO. \\ Evergreen Specialists-Largest Growers in America DUNDEE, ILLINOIS}

Name

R. F. D. or Street

\section{Postoffice}

County

Express or

Freight Office

State

\section{Amount of Cash Enclosed}

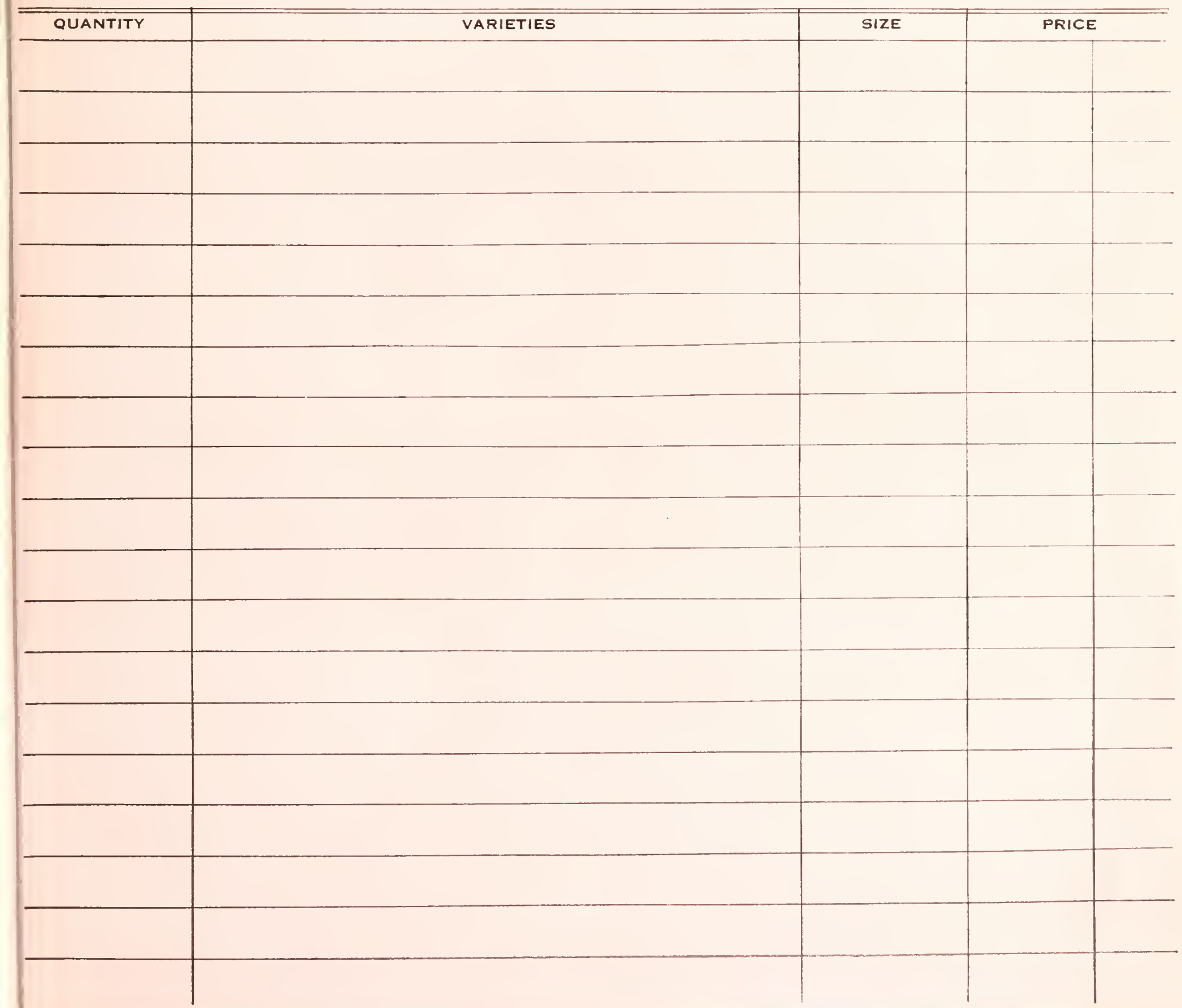




